\title{
Taming Radical Pairs in the Crystalline Solid State: Discovery and Total Synthesis of Psychotriadine
}

Jordan J. Dotson, Ieva Liepuoniute, J. Logan Bachman, Vince M. Hipwell, Saeed

I Khan, K. N. Houk,* Neil K. Garg,* and Miguel A. Garcia-Garibay

Department of Chemistry and Biochemistry, University of California, Los Angeles, California 90095

Supporting Information - Table of Contents

Materials and Methods

Experimental Procedures …………………………..........................................................

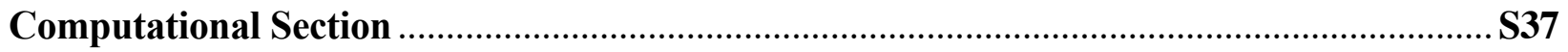

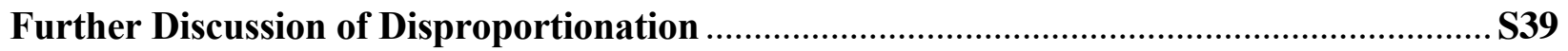

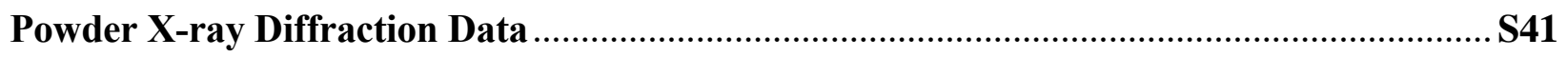

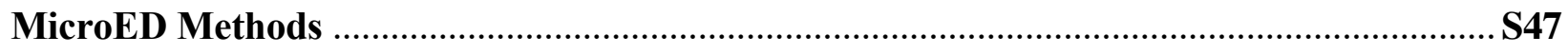

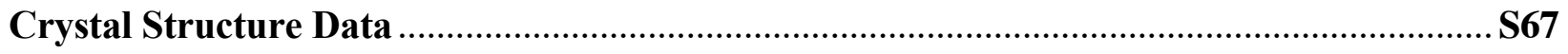

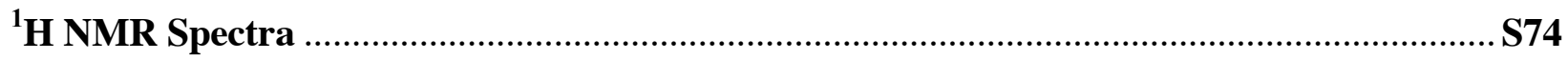

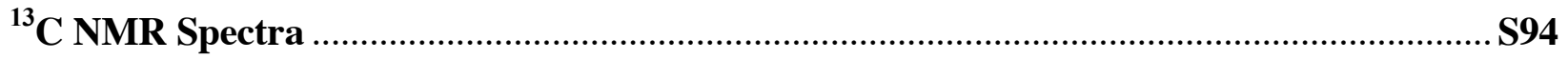

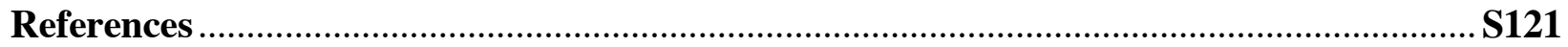




\section{Materials and Methods}

Unless stated otherwise, reactions were conducted in flame-dried glassware under an atmosphere of nitrogen using anhydrous solvents (either freshly distilled or passed through activated alumina columns). All commercially available reagents were used as received unless otherwise specified. Sodium hydride $(60 \%$ dispersion in mineral oil), oxalyl chloride, iodomethane (MeI), bromoacetonitrile, lithium bis(trimethylsilyl)amide (LiHMDS), ceric ammonium nitrate, and sodium borohydride were obtained from Sigma-Aldrich. Cobalt(II) chloride hexahydrate and 4-methoxybenzyl chloride were purchased from TCI America. Unless stated otherwise, reactions were performed at room temperature (rt, approximately $23^{\circ} \mathrm{C}$ ). Thinlayer chromatography (TLC) was conducted with EMD gel 60 F254 pre-coated plates $(0.25 \mathrm{~mm})$ and visualized using a combination of UV, ceric ammonium molybdate, and potassium permanganate staining. Silicycle silica gel 60 (particle size $0.040-0.063 \mathrm{~mm}$ ) was used for flash column chromatography. Compounds 9a, 17f, and $\mathbf{1 6 f}$ were purified using a Teledyne ISCO CombiFlash $^{\circledR} \mathrm{NextGen}^{\mathrm{TM}}$ instrument using RediSep ${ }^{\star R f}$ high-performance silica gold columns (24 g, catalog No. 692203346). ${ }^{1} \mathrm{H}$ NMR spectra were recorded on Bruker spectrometers (at 500 $\mathrm{MHz}$ or $600 \mathrm{MHz}$ ) and are reported relative to deuterated solvent signals. Data for ${ }^{1} \mathrm{H}$ NMR spectra are reported as follows: chemical shift $(\delta \mathrm{ppm})$, multiplicity, coupling constant $(\mathrm{Hz})$ and integration. ${ }^{13} \mathrm{C}$ NMR spectra are reported in terms of chemical shift (at $125 \mathrm{MHz}$ ). Highresolution mass spectra were obtained on Thermo Scientific ${ }^{\mathrm{TM}}$ Exactive Mass Spectrometers with DART ID-CUBE. X-ray structures shown in Figures 4, 5, 6, and 7 and Scheme 6 of the manuscript were created using CYLview. 


\section{Experimental Procedures}

Note: For experimental information on compounds $9 \mathbf{e}, 11 \mathbf{e}, 15 \mathbf{e}, 16 \mathbf{e}, 17 \mathbf{e}, 18 \mathbf{e}, 24 \mathbf{e}, 25 \mathbf{e}, 26 \mathbf{e}$, 27e, 28e, 29e, 31e, 36, 39, and 40e, see reference 1. For experimental data on 15a, 16a, 17a, 11a, and $9 \mathbf{a}$, see reference 2 .

Synthesis of Ketones 11 .
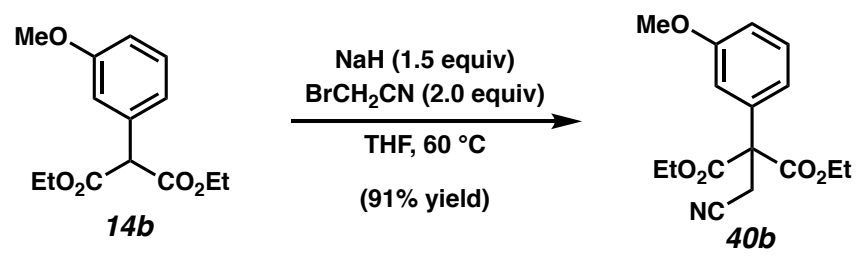

Nitrile 40b. To a suspension of $\mathrm{NaH}(2.78 \mathrm{~g}, 60 \% \mathrm{w} / \mathrm{w}, 69.5 \mathrm{mmol}, 1.50$ equiv) was added a solution of $m$-methoxyphenyl malonate ester 14b (11.1 g, $41.7 \mathrm{mmol}, 1.00$ equiv) in THF (100 $\mathrm{mL})$ via canula. Bromoacetonitrile $(5.8 \mathrm{~mL}, 10 \mathrm{~g}, 83 \mathrm{mmol}, 2.00$ equiv) was then added dropwise over $1 \mathrm{~min}$ via syringe. The reaction was stirred for $10 \mathrm{~min}$ and then submerged in an oil bath preheated to $60{ }^{\circ} \mathrm{C}$ and stirred for $15 \mathrm{~min}$. The reaction was then cooled to $23{ }^{\circ} \mathrm{C}$ and quenched with aq. $\mathrm{HCl}(0.5 \mathrm{M}, 20 \mathrm{~mL})$. The reaction mixture was poured into a biphasic mixture of aq. $\mathrm{HCl}(0.5 \mathrm{M}, 50 \mathrm{~mL})$ and $\mathrm{EtOAc}(75 \mathrm{~mL})$. The layers were then separated and the aqueous layer was extracted with EtOAc (2 x $100 \mathrm{~mL})$. The combined organic layers were washed with sat. aq. $\mathrm{NaCl}(100 \mathrm{~mL})$, dried over $\mathrm{Na}_{2} \mathrm{SO}_{4}$, and concentrated under reduced pressure directly onto silica gel (20 g). The crude product was then purified by flash column chromatography ( 80 g silica gel, 9:1 Hexanes:EtOAc $\rightarrow$ 7:3 Hexanes:EtOAc) to yield 40b as a white solid (11.5 g, 91\% yield). Nitrile 40b: $\mathrm{R}_{\mathrm{f}} 0.41$ (7:3 Hexanes:EtOAc); ${ }^{1} \mathrm{H}$ NMR $\left(500 \mathrm{MHz}, \mathrm{CDCl}_{3}\right) \delta 7.31(\mathrm{td}, J$ $=7.4,1.8 \mathrm{~Hz}, 1 \mathrm{H}), 6.97-6.81(\mathrm{~m}, 3 \mathrm{H}), 4.42-4.25(\mathrm{~m}, 4 \mathrm{H}), 3.81(\mathrm{~s}, 3 \mathrm{H}), 3.23(\mathrm{~s}, 2 \mathrm{H}), 1.31(\mathrm{t}, J$ $=7.1 \mathrm{~Hz}, 6 \mathrm{H}) ;{ }^{13} \mathrm{C} \mathrm{NMR}\left(125 \mathrm{MHz}, \mathrm{CDCl}_{3}\right) \delta 168.2,159.8,136.5,129.9,119.5,116.8,113.9$, 
113.9, 63.1, 60.8, 55.4, 26.4, 14.1; HRMS-APCI $(\mathrm{m} / \mathrm{z})[\mathrm{M}+\mathrm{H}]^{+}$calcd for $\mathrm{C}_{16} \mathrm{H}_{20} \mathrm{NO}_{5}^{+}$, 306.1336; found 306.1321 .
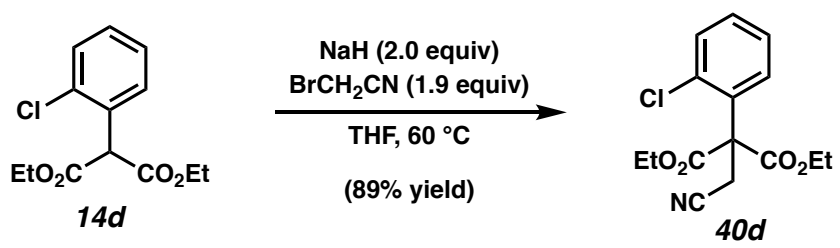

Nitrile 40d. To a solution of $o$-chlorophenyl malonate ester $14 \mathrm{~d}(20.0 \mathrm{~g}, 73.9 \mathrm{mmol}, 1.00$ equiv) in THF $(250 \mathrm{~mL})$, was added $\mathrm{NaH}(5.91 \mathrm{~g}, 60 \% \mathrm{w} / \mathrm{w}, 150 \mathrm{mmol}, 2.00$ equiv) in two portions over 5 min with stirring. Bromoacetonitrile $(7.73 \mathrm{~mL}, 10.2 \mathrm{~g}, 85.0 \mathrm{mmol}, 1.50$ equiv) was added dropwise over 1 minute via syringe. The reaction was submerged in an oil bath preheated to 60 ${ }^{\circ} \mathrm{C}$ and stirred for $2 \mathrm{~h}$. After cooling the mixture to $23{ }^{\circ} \mathrm{C}$, an additional aliquot of bromoacetonitrile ( $2.0 \mathrm{~mL}, 3.4 \mathrm{~g}, 29 \mathrm{mmol}, 0.39$ equiv) was added dropwise via syringe over 1 minute. The reaction was placed in an oil bath preheated to $60{ }^{\circ} \mathrm{C}$ and stirred for $18 \mathrm{~h}$. The mixture was then cooled to $23{ }^{\circ} \mathrm{C}$ and poured into a biphasic mixture of sat. aq. $\mathrm{NH}_{4} \mathrm{Cl}(400 \mathrm{~mL})$ and $\mathrm{CH}_{2} \mathrm{Cl}_{2}(300 \mathrm{~mL})$. The layers were separated and the aqueous layer was extracted with $\mathrm{CH}_{2} \mathrm{Cl}_{2}(2 \times 100 \mathrm{~mL})$. The organic layers were combined and dried over $\mathrm{MgSO}_{4}$ and concentrated under reduced pressure directly onto silica gel $(30 \mathrm{~g})$. The crude product was then purified by flash column chromatography ( $30 \mathrm{~g}$ silica gel, 9:1 Hexanes:EtOAc) to yield 40d as a white solid (20.5 g, 89\% yield). Nitrile 40d: mp: $63.7-68.0{ }^{\circ} \mathrm{C} ; \mathrm{R}_{\mathrm{f}} 0.46$ (7:3 Hexanes:EtOAc); ${ }^{1} \mathrm{H}$ NMR (500 MHz, $\left.\mathrm{CDCl}_{3}\right) \delta 7.45-7.41(\mathrm{~m}, 1 \mathrm{H}), 7.37-7.30(\mathrm{~m}, 2 \mathrm{H}), 7.22-7.16(\mathrm{~m}, 1 \mathrm{H}), 4.46-$ $4.19(\mathrm{~m}, 4 \mathrm{H}), 3.46(\mathrm{~s}, 2 \mathrm{H}), 1.31(\mathrm{t}, J=7.1 \mathrm{~Hz}, 6 \mathrm{H}) ;{ }^{13} \mathrm{C} \mathrm{NMR}\left(125 \mathrm{MHz}, \mathrm{CDCl}_{3}\right) \delta 167.7,133.5$, 133.1, 131.4, 130.3, 130.2, 127.6, 116.9, 63.4, 61.8, 23.8, 13.9; HRMS-APCI $(\mathrm{m} / \mathrm{z})[\mathrm{M}+\mathrm{H}]^{+}$ calcd for $\mathrm{C}_{15} \mathrm{H}_{17} \mathrm{NO}_{4} \mathrm{Cl}^{+}, 310.0846$; found 310.0830 . 

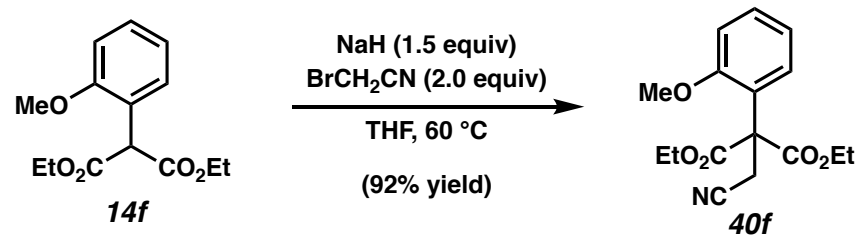

Nitrile 40f. To a solution of $o$-methoxyphenyl malonate ester $14 \mathrm{f}(11.2 \mathrm{~g}, 42.1 \mathrm{mmol}, 1.00$ equiv) in THF ( $140 \mathrm{~mL})$, was added $\mathrm{NaH}(2.52 \mathrm{~g}, 60 \% \mathrm{w} / \mathrm{w}, 63 \mathrm{mmol}, 1.5$ equiv) over $5 \mathrm{~min}$ with stirring. Bromoacetonitrile (5.90 mL, $10.1 \mathrm{~g}, 84.2 \mathrm{mmol}, 2.00$ equiv) was added dropwise over 1 min via syringe. The reaction was submerged in an oil bath preheated to $60{ }^{\circ} \mathrm{C}$ and stirred for $50 \mathrm{~min}$. The reaction was cooled to $23{ }^{\circ} \mathrm{C}$ and poured into a biphasic mixture of sat. aq. $\mathrm{NH}_{4} \mathrm{Cl}(100 \mathrm{~mL})$ and EtOAc $(100 \mathrm{~mL})$. The layers were separated, and the aqueous layer was extracted with EtOAc $(2 \times 100 \mathrm{~mL})$. The combined organic layers were washed with sat. aq. $\mathrm{NaCl}(100 \mathrm{~mL})$, dried over $\mathrm{MgSO}_{4}$, and concentrated under reduced pressure directly onto silica gel $(20 \mathrm{~g})$. The crude product was then purified by flash column chromatography ( $80 \mathrm{~g}$ silica, 9:1 Hexanes:EtOAc $\rightarrow 3: 2$ Hexanes:EtOAc) to yield $\mathbf{4 0 f}$ as a white solid (11.8 g, 92\% yield). Nitrile 40f: $\mathrm{R}_{\mathrm{f}} 0.55$ (1:1 Hexanes:EtOAc); ${ }^{1} \mathrm{H}$ NMR $\left(500 \mathrm{MHz}, \mathrm{CDCl}_{3}\right) \delta 7.35(\mathrm{t}, J=7.8 \mathrm{~Hz}, 1 \mathrm{H}), 7.10$ $(\mathrm{d}, J=7.7 \mathrm{~Hz}, 1 \mathrm{H}), 6.99$ (t, $J=7.6 \mathrm{~Hz}, 1 \mathrm{H}), 6.92(\mathrm{~d}, J=8.2 \mathrm{~Hz}, 1 \mathrm{H}), 4.40-4.22(\mathrm{~m}, 4 \mathrm{H}), 3.79$ (s, 3H), $3.31(\mathrm{~s}, 2 \mathrm{H}), 1.29(\mathrm{t}, J=7.1 \mathrm{~Hz}, 6 \mathrm{H}) ;{ }^{13} \mathrm{C} \mathrm{NMR}\left(125 \mathrm{MHz}, \mathrm{CDCl}_{3}\right) \delta 168.6,156.4$, 130.3, 128.8, 124.9, 121.3, 117.7, 111.6, 62.8, 59.7, 55.5, 24.0, 14.1; HRMS-APCI (m/z) [M + $\mathrm{H}]^{+}$calcd for $\mathrm{C}_{16} \mathrm{H}_{20} \mathrm{NO}_{5}, 306.1336$; found 306.1332 .
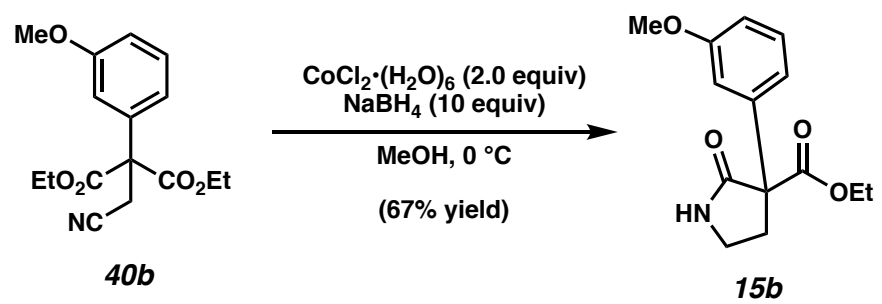

Pyrrolidinone 15b. To a solution of nitrile 40b (6.50 g, $21.3 \mathrm{mmol}, 1.00$ equiv) in $\mathrm{MeOH}$ (210 $\mathrm{mL})$, was added $\mathrm{CoCl}_{2} \bullet\left(\mathrm{H}_{2} \mathrm{O}\right)_{6}(10.1 \mathrm{~g}, 43.6 \mathrm{mmol}, 2.00$ equiv $)$ all at once with stirring. The 
reaction was then cooled to $0{ }^{\circ} \mathrm{C}$ and $\mathrm{NaBH}_{4}(8.05 \mathrm{~g}, 213 \mathrm{mmol}, 10.0$ equiv) was added portionwise (Note 1) over $10 \mathrm{~min}$. The reaction was allowed to warm to $23{ }^{\circ} \mathrm{C}$ and was poured into a biphasic mixture of sat. aq. $\mathrm{NH}_{4} \mathrm{Cl}(260 \mathrm{~mL})$, sat. aq. $\mathrm{NaCl}(200 \mathrm{~mL})$, and EtOAc (400 $\mathrm{mL})$. The layers were separated and the aqueous layer was extracted with EtOAc $(1 \times 200 \mathrm{~mL})$. The combined organic layers were dried over $\mathrm{MgSO}_{4}$ and concentrated under reduced pressure directly onto silica gel $(8 \mathrm{~g})$. The crude product was purified by flash column chromatography (30 g silica gel, 1:1 Hexanes:EtOAc $\rightarrow$ 1:4 Hexanes:EtOAc) to give pyrrolidinone 15b (3.75 g, $67 \%$ yield) as a viscous oil. Pyrrolidinone 15b: $\mathrm{R}_{\mathrm{f}} 0.42$ (1:4 Hexanes:EtOAc); ${ }^{1} \mathrm{H}$ NMR (500 $\left.\mathrm{MHz}, \mathrm{CDCl}_{3}\right) \delta 7.32(\mathrm{dd}, J=7.7,1.7 \mathrm{~Hz}, 1 \mathrm{H}), 7.30-7.24(\mathrm{~m}, 1 \mathrm{H}), 7.20(\mathrm{~s}, 1 \mathrm{H}), 6.95(\mathrm{td}, J=$ 7.6, $1.2 \mathrm{~Hz}, 1 \mathrm{H}), 6.88(\mathrm{dd}, J=8.2,1.1 \mathrm{~Hz}, 1 \mathrm{H}), 4.30(\mathrm{dq}, J=10.7,7.1 \mathrm{~Hz}, 1 \mathrm{H}), 4.13(\mathrm{dq}, J=$ 10.8, $7.1 \mathrm{~Hz}, 1 \mathrm{H}), 3.78(\mathrm{~s}, 3 \mathrm{H}), 3.52-3.40(\mathrm{~m}, 1 \mathrm{H}), 3.32(\mathrm{ddd}, J=13.0,8.2,6.8 \mathrm{~Hz}, 1 \mathrm{H}), 3.26-$ $3.15(\mathrm{~m}, 1 \mathrm{H}), 2.19(\mathrm{ddd}, J=13.0,7.5,4.2 \mathrm{~Hz}, 1 \mathrm{H}), 1.19(\mathrm{t}, J=7.1 \mathrm{~Hz}, 3 \mathrm{H}) ;{ }^{13} \mathrm{C}$ NMR $(125$ $\left.\mathrm{MHz}, \mathrm{CDCl}_{3}\right) \delta 174.2,170.6159 .8,139.4,129.6,119.7,113.5,113.0,62.3,59.8,55.4,39.4$ 34.9, 14.2; HRMS-APCI (m/z) [M+ H] $]^{+}$calcd for $\mathrm{C}_{14} \mathrm{H}_{18} \mathrm{NO}_{4}{ }^{+}, 264.1230$; found 264.1218.

Note 1: It is critical that $\mathrm{NaBH}_{4}$ is added slowly, the reaction vigorously releases $\mathrm{H}_{2}$ gas. The solid was added in roughly equal quantities every $\sim 30$ seconds for 10 min to prevent the mixture from erupting out of the flask.
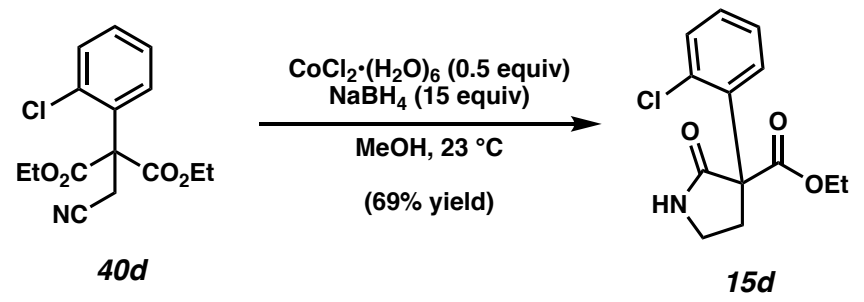

Pyrrolidinone 15d. To a solution of nitrile 40d (10.4 g, 33.6 mmol, 1.00 equiv) in $\mathrm{MeOH}$ (400 $\mathrm{mL})$, was added $\mathrm{CoCl}_{2} \bullet\left(\mathrm{H}_{2} \mathrm{O}\right)_{6}\left(4.0 \mathrm{~g}, 17 \mathrm{mmol}, 0.50\right.$ equiv) all at once with stirring. $\mathrm{NaBH}_{4}(19$ g, 500 mmol, 15.0 equiv) was added portionwise (Note 1) over $10 \mathrm{~min}$ and the reaction was 
stirred a further $10 \mathrm{~min}$ at $23{ }^{\circ} \mathrm{C}$. Aq. $\mathrm{HCl}(2 \mathrm{M}, 200 \mathrm{~mL})$ was added and the reaction was stirred for $10 \mathrm{~min}$. Aq. $\mathrm{NH}_{4} \mathrm{OH}(30-32 \% \mathrm{w} / \mathrm{v}, 300 \mathrm{~mL})$ was then added and stirred for $10 \mathrm{~min}$ before the reaction mixture was poured into a biphasic mixture of sat. aq. $\mathrm{NaCl}(200 \mathrm{~mL})$ and $\mathrm{EtOAc}(400$ $\mathrm{mL})$. The layers were separated and the aqueous layer was extracted with EtOAc $(2 \times 200 \mathrm{~mL})$. The combined organic layers were washed with sat. aq. $\mathrm{NaCl}(100 \mathrm{~mL})$, dried over $\mathrm{MgSO}_{4}$, and concentrated under reduced pressure directly onto silica gel $(20 \mathrm{~g})$. The crude product was then purified by flash column chromatography $(50 \mathrm{~g}$ silica gel, 3:2 Hexanes:EtOAc $\rightarrow$ 3:7 Hexanes:EtOAc) to yield 15d as a viscous oil (6.16 g, 69\% yield). Pyrrolidinone 15d: $R_{\mathrm{f}} 0.19$ (1:1 Hexanes:EtOAc); ${ }^{1} \mathrm{H}$ NMR $\left(500 \mathrm{MHz}, \mathrm{CDCl}_{3}\right) \delta 7.33(\mathrm{~s}, 1 \mathrm{H}), 7.28(\mathrm{dd}, J=7.3,2.2 \mathrm{~Hz}, 1 \mathrm{H})$, $7.20(\mathrm{dd}, J=7.2,2.1 \mathrm{~Hz}, 1 \mathrm{H}), 7.11-7.01(\mathrm{~m}, 2 \mathrm{H}), 4.11(\mathrm{dq}, J=10.8,7.1 \mathrm{~Hz}, 1 \mathrm{H}), 4.00(\mathrm{dq}, J=$ 10.8, 7.1 Hz, 1H), $3.39-3.20(\mathrm{~m}, 2 \mathrm{H}), 3.08-2.95(\mathrm{~m}, 1 \mathrm{H}), 2.14$ (ddd, $J=13.2,7.6,3.3 \mathrm{~Hz}$, 1H), $1.03(\mathrm{t}, J=7.1 \mathrm{~Hz}, 3 \mathrm{H}) ;{ }^{13} \mathrm{C} \mathrm{NMR}\left(125 \mathrm{MHz}, \mathrm{CDCl}_{3}\right) \delta 174.4,170.3,137.2,133.9,130.7$, $128.9,128.7,127.2,62.6,61.4,39.7,33.5,14.0 ;$ HRMS-APCI $(\mathrm{m} / \mathrm{z})[\mathrm{M}+\mathrm{H}]^{+}$calcd for $\mathrm{C}_{13} \mathrm{H}_{15} \mathrm{NO}_{3} \mathrm{Cl}^{+}, 268.0740$; found 268.0727.

Note 1: It is critical that $\mathrm{NaBH}_{4}$ is added slowly, the reaction vigorously releases $\mathrm{H}_{2}$ gas. The solid was added in roughly equal quantities every 30 seconds for 10 min to prevent the mixture from erupting out of the flask.
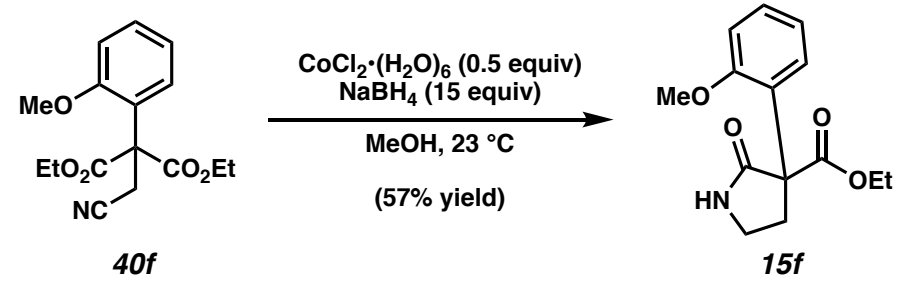

Pyrrolidinone 15f. To a solution of nitrile $40 f$ (5.87 g, $19.2 \mathrm{mmol}, 1.00$ equiv) in $\mathrm{MeOH}$ (200 $\mathrm{mL})$, was added $\mathrm{CoCl}_{2} \bullet\left(\mathrm{H}_{2} \mathrm{O}\right)_{6}\left(2.45 \mathrm{~g}, 10.3 \mathrm{mmol}, 0.50\right.$ equiv) all at once with stirring. $\mathrm{NaBH}_{4}$ (11.0 g, $291 \mathrm{mmol}, 15.0$ equiv) was added portionwise (Note 1) over $20 \mathrm{~min}$. Aq. HCl (1 M, 200 
$\mathrm{mL}$ ) was then added and the reaction was allowed to stir for $5 \mathrm{~min}$ before being poured into a biphasic mixture of aq. $\mathrm{NH}_{4} \mathrm{OH}(30-32 \% \mathrm{w} / \mathrm{v}, 200 \mathrm{~mL})$, sat. aq. $\mathrm{NaCl}(150 \mathrm{~mL})$, and EtOAc $(300 \mathrm{~mL})$. The layers were separated, and the aqueous layer was extracted with $\mathrm{CH}_{2} \mathrm{Cl}_{2}(2 \times 150$ $\mathrm{mL}$ ). The combined organic layers were dried over $\mathrm{MgSO}_{4}$ and concentrated under reduced pressure directly onto silica gel $(20 \mathrm{~g})$. The crude product was then purified by flash column chromatography (50 g silica gel, 7:3 Hexanes:EtOAc $\rightarrow$ 1:1 Hexanes:EtOAc $\rightarrow$ 1:1 $\mathrm{CH}_{2} \mathrm{Cl}_{2} /$ EtOAc) to yield $\mathbf{1 5 f}$ as a white solid (3.04 g, 57\% yield). Pyrrolidinone 15f: $\mathrm{R}_{\mathrm{f}} 0.41$ (1:4 Hexanes:EtOAc); ${ }^{1} \mathrm{H}$ NMR $\left(500 \mathrm{MHz}, \mathrm{CDCl}_{3}\right) \delta 7.32-7.23(\mathrm{~m}, 1 \mathrm{H}), 7.11-6.94(\mathrm{~m}, 2 \mathrm{H}), 6.84$ $(\mathrm{dd}, J=8.3,2.5 \mathrm{~Hz}, 1 \mathrm{H}), 6.64(\mathrm{~s}, 1 \mathrm{H}), 4.31-4.15(\mathrm{~m}, 2 \mathrm{H}), 3.81(\mathrm{~s}, 3 \mathrm{H}), 3.51-3.38(\mathrm{~m}, 1 \mathrm{H})$, $3.36-3.25(\mathrm{~m}, 1 \mathrm{H}), 3.12(\mathrm{ddd}, J=12.8,7.4,5.2 \mathrm{~Hz}, 1 \mathrm{H}), 2.49(\mathrm{ddd}, J=13.2,7.3,6.0 \mathrm{~Hz}, 1 \mathrm{H})$, $1.25(\mathrm{t}, J=7.1 \mathrm{~Hz}, 3 \mathrm{H}) ;{ }^{13} \mathrm{C} \mathrm{NMR}\left(125 \mathrm{MHz}, \mathrm{CDCl}_{3}\right) \delta 175.0,171.0,156.9,128.8,128.2,127.7$, $120.9,110.9,61.8,58.9,55.3,39.7,33.6,14.2 ;$ HRMS-APCI $(\mathrm{m} / \mathrm{z})[\mathrm{M}+\mathrm{H}]^{+}$calcd for $\mathrm{C}_{14} \mathrm{H}_{18} \mathrm{NO}_{4}{ }^{+}, 264.1230$; found 264.1229.

Note 1: It is critical that $\mathrm{NaBH}_{4}$ is added slowly, the reaction vigorously releases $\mathrm{H}_{2}$ gas. The solid was added in roughly equal quantities every 30 seconds for 20 min to prevent the mixture from erupting out of the flask.
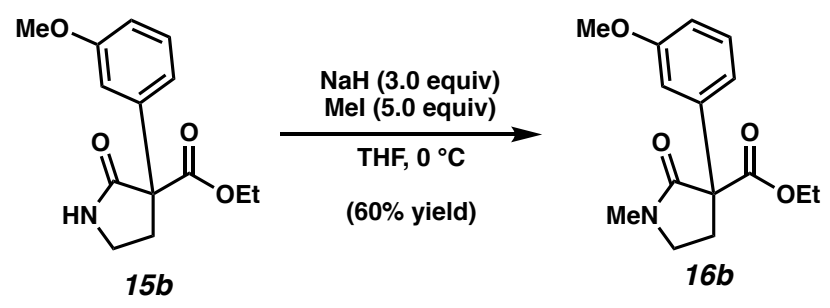

Pyrrolidinone 16b. A solution of pyrrolidinone 15b (940 mg, $3.57 \mathrm{mmol}, 1.0$ equiv) in THF (25 $\mathrm{mL}$ ) was added over $5 \mathrm{~min}$ via syringe to a $0{ }^{\circ} \mathrm{C}$ suspension of $\mathrm{NaH}(430 \mathrm{mg}, 10.7 \mathrm{mmol}, 3.0$ equiv, 60\% dispersion in mineral oil) in THF $(10 \mathrm{~mL})$. The reaction was stirred for $20 \mathrm{~min}$ before MeI (1.1 mL, $2.5 \mathrm{~g}, 18 \mathrm{mmol}, 5.0$ equiv) was added dropwise over $1 \mathrm{~min}$. The reaction 
was stirred at $0{ }^{\circ} \mathrm{C}$ for $45 \mathrm{~min}$ and then poured into a slurry of sat. aq. $\mathrm{NH}_{4} \mathrm{Cl}(50 \mathrm{~mL})$ and ice. EtOAc $(100 \mathrm{~mL})$ was added, the layers were separated, and the aqueous layer was further extracted with EtOAc $(2 \times 30 \mathrm{~mL})$. The combined organic layers were washed with sat. aq. $\mathrm{NaCl}$ $(30 \mathrm{~mL})$, dried over $\mathrm{Na}_{2} \mathrm{SO}_{4}$, and concentrated under reduced pressure directly onto silica gel $(1.5 \mathrm{~g})$. The crude product was purified by flash column chromatography (7 $\mathrm{g}$ silica gel, 4:1 Hexanes:EtOAc $\rightarrow$ 1:1 Hexanes:EtOAc) to provide pyrrolidinone $\mathbf{1 6 b}(940 \mathrm{mg}, 60 \%$ yield) as a viscous oil. Pyrrolidinone 16b: $\mathrm{R}_{\mathrm{f}} 0.47$ (1:4 Hexanes:EtOAc); ${ }^{1} \mathrm{H}$ NMR $\left(500 \mathrm{MHz}, \mathrm{CDCl}_{3}\right) \delta$ $7.39-7.30(\mathrm{~m}, 1 \mathrm{H}), 7.12-7.09(\mathrm{~m}, 1 \mathrm{H}), 7.09-7.01(\mathrm{~m}, 1 \mathrm{H}), 6.94-6.86(\mathrm{~m}, 1 \mathrm{H}), 4.48-4.14$ (m, 2H), $3.87(\mathrm{~s}, 3 \mathrm{H}), 3.57-3.46(\mathrm{~m}, 1 \mathrm{H}), 3.42-3.30(\mathrm{~m}, 1 \mathrm{H}), 3.09$ (ddd, $J=12.9,7.7,5.1 \mathrm{~Hz}$, 1H), 3.02 (s, 3H), 2.46 (dt, $J=13.3,6.9 \mathrm{~Hz}, 1 \mathrm{H}), 1.30(\mathrm{t}, J=7.1 \mathrm{~Hz}, 3 \mathrm{H}) ;{ }^{13} \mathrm{C}$ NMR $(125 \mathrm{MHz}$, $\left.\mathrm{CDCl}_{3}\right) \delta 170.9,170.7,159.7,139.9,129.5,119.6,113.4,113.00,62.2,60.5,55.4,46.5,32.3$, 30.6, 14.2; HRMS-APCI (m/z) $[\mathrm{M}+\mathrm{H}]^{+}$calcd for $\mathrm{C}_{15} \mathrm{H}_{20} \mathrm{NO}_{4}{ }^{+}, 278.1387$; found 278.1375.
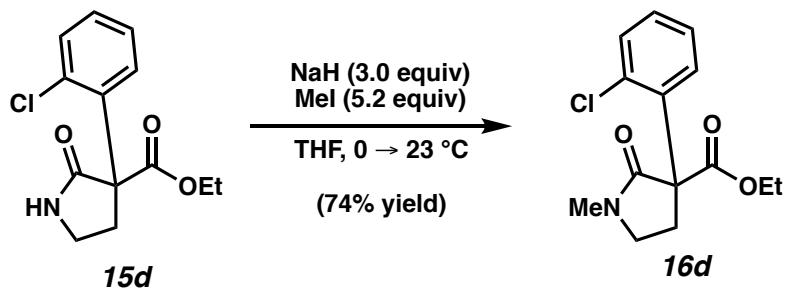

Pyrrolidinone 16d. To a $0{ }^{\circ} \mathrm{C}$ suspension of $\mathrm{NaH}(420 \mathrm{mg}, 11 \mathrm{mmol}, 3.0$ equiv, $60 \%$ dispersion in mineral oil) in THF (20 mL) was added a solution of pyrrolidinone $15 \mathbf{d}(935 \mathrm{mg}, 3.49 \mathrm{mmol}$, 1.00 equiv) in THF $(20 \mathrm{~mL})$. The reaction was stirred for $45 \mathrm{~min}$ at $0{ }^{\circ} \mathrm{C}$ and $\mathrm{MeI}(0.90 \mathrm{~mL}, 2.6$ g, $18 \mathrm{mmol}, 5.2$ equiv) was added dropwise over $1 \mathrm{~min}$ via syringe. The reaction was removed from the $0{ }^{\circ} \mathrm{C}$ bath, stirred for $15 \mathrm{~min}$, and then poured into a slurry of aq. $\mathrm{HCl}(0.5 \mathrm{M}, 100 \mathrm{~mL})$ and ice. The crude mixture was extracted with EtOAc $(3 \times 100 \mathrm{~mL})$ and the combined organic layers were dried over $\mathrm{MgSO}_{4}$ before being concentrated under reduced pressure directly onto silica gel $(2.5 \mathrm{~g})$. The crude product was then purified by flash column chromatography (15 g 
silica gel, 7:3 Hexanes:EtOAc $\rightarrow$ 1:1 Hexanes:EtOAc) to provide pyrrolidinone 16d (731 mg, $74 \%$ yield) as a viscous oil. Pyrrolidinone 16d: $\mathrm{R}_{\mathrm{f}} 0.19$ (7:3 Hexanes:EtOAc); ${ }^{1} \mathrm{H}$ NMR (500 $\left.\mathrm{MHz}, \mathrm{CDCl}_{3}\right) \delta 7.28-7.20(\mathrm{~m}, 2 \mathrm{H}), 7.14-7.06(\mathrm{~m}, 2 \mathrm{H}), 4.20-4.11(\mathrm{~m}, 1 \mathrm{H}), 4.10-4.01(\mathrm{~m}$, 1H), $3.46-3.32(\mathrm{~m}, 1 \mathrm{H}), 3.26(\mathrm{ddd}, J=13.4,8.6,6.3 \mathrm{~Hz}, 1 \mathrm{H}), 3.19-3.06(\mathrm{~m}, 1 \mathrm{H}), 2.87(\mathrm{~s}, 3 \mathrm{H})$, 2.09 (ddd, $J=12.6,8.0,4.2 \mathrm{~Hz}, 1 \mathrm{H}), 1.09(\mathrm{t}, J=7.1 \mathrm{~Hz}, 3 \mathrm{H}) ;{ }^{13} \mathrm{C} \mathrm{NMR}\left(125 \mathrm{MHz}, \mathrm{CDCl}_{3}\right) \delta$ $170.5,170.2,137.9,133.9,130.6,129.0,128.8,127.2,62.5,61.9,46.7,31.1,30.7,14.1$; HRMSAPCI $(\mathrm{m} / \mathrm{z})[\mathrm{M}+\mathrm{H}]^{+}$calcd for $\mathrm{C}_{14} \mathrm{H}_{17} \mathrm{NO}_{3} \mathrm{Cl}^{+}, 282.0897$; found 282.0888 .
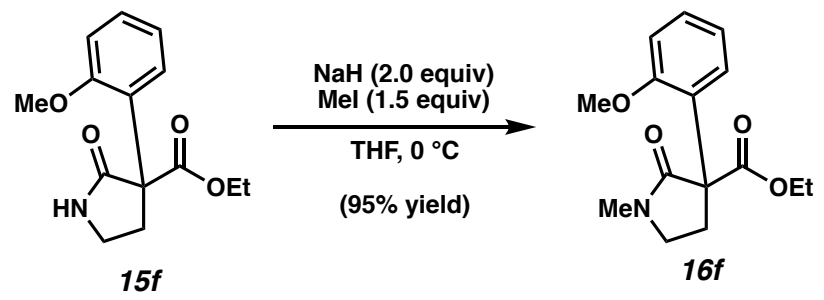

Pyrrolidinone 16f. To a solution of pyrrolidinone $\mathbf{1 5 f}(1.50 \mathrm{~g}, 5.70 \mathrm{mmol}, 1.00$ equiv) in THF (50 mL), was added $\mathrm{NaH}(460 \mathrm{mg}, 11 \mathrm{mmol}, 2$ equiv, 60\% dispersion in mineral oil) in 2 portions over 5 min with stirring. The reaction was stirred at $23{ }^{\circ} \mathrm{C}$ for $15 \mathrm{~min}$ before being placed in a $0{ }^{\circ} \mathrm{C}$ bath. MeI $(0.53 \mathrm{~mL}, 1.21 \mathrm{~g}, 8.6 \mathrm{mmol}, 1.5$ equiv) was added dropwise over 1 min via syringe. The reaction was stirred at $0{ }^{\circ} \mathrm{C}$ for $2 \mathrm{~h}$ and then poured into a biphasic mixture of sat. aq. $\mathrm{NH}_{4} \mathrm{Cl}(100 \mathrm{~mL})$ and $\mathrm{CH}_{2} \mathrm{Cl}_{2}(200 \mathrm{~mL})$. The layers were separated, and the aqueous layer was extracted with $\mathrm{CH}_{2} \mathrm{Cl}_{2}(2 \times 100 \mathrm{~mL})$. The combined organic layers were dried over $\mathrm{MgSO}_{4}$ before being concentrated under reduced pressure. The crude product was purified by flash column chromatography (RediSep Gold 25 g silica gel, 9:1 Hexanes:EtOAc $\rightarrow$ 7:3 Hexanes:EtOAc) to provide pyrrolidinone $\mathbf{1 6 f}(1.50 \mathrm{~g}, 95 \%$ yield $)$ as a white solid. Pyrrolidinone 16f: $\mathrm{R}_{\mathrm{f}} 0.47$ (3:7 Hexanes:EtOAc); ${ }^{1} \mathrm{H}$ NMR $\left(500 \mathrm{MHz}, \mathrm{CDCl}_{3}\right) \delta 7.32-7.22(\mathrm{~m}, 1 \mathrm{H}), 7.20(\mathrm{~d}, J$ $=7.6 \mathrm{~Hz}, 1 \mathrm{H}), 6.92(\mathrm{t}, J=7.5 \mathrm{~Hz}, 1 \mathrm{H}), 6.86(\mathrm{~d}, J=8.1 \mathrm{~Hz}, 1 \mathrm{H}), 4.32-4.19(\mathrm{~m}, 1 \mathrm{H}), 4.19-4.04$ (m, 1H), $3.77(\mathrm{~s}, 3 \mathrm{H}), 3.54-3.38(\mathrm{~m}, 1 \mathrm{H}), 3.29-3.16(\mathrm{~m}, 2 \mathrm{H}), 2.97(\mathrm{~s}, 3 \mathrm{H}), 2.05(\mathrm{td}, J=10.8$ 
10.3, $6.7 \mathrm{~Hz}, 1 \mathrm{H}), 1.17(\mathrm{t}, J=7.1 \mathrm{~Hz}, 3 \mathrm{H}) ;{ }^{13} \mathrm{C} \mathrm{NMR}\left(125 \mathrm{MHz}, \mathrm{CDCl}_{3}\right) \delta 171.4,170.9,156.89$, 129.0, 128.7, 127.7, 120.9, 110.9, 61.8, 59.5, 55.3, 46.8, 31.2, 30.6, 14.2; HRMS-APCI (m/z) [M $+\mathrm{H}]^{+}$calcd for $\mathrm{C}_{15} \mathrm{H}_{20} \mathrm{NO}_{4}{ }^{+}, 278.1387$; found 278.1384.

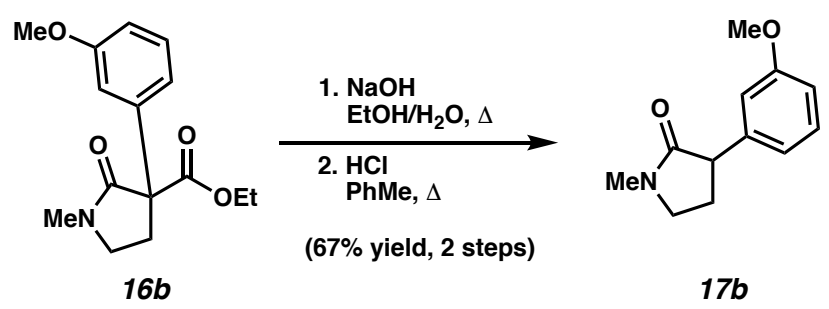

Pyrrolidinone 17b. To a solution of pyrrolidinone $16 \mathbf{b}(750 \mathrm{mg}, 5.10 \mathrm{mmol}, 1.00$ equiv) in EtOH $(10 \mathrm{~mL})$, was added aq. $\mathrm{NaOH}(1 \mathrm{M}, 17 \mathrm{~mL})$. The reaction was placed in a preheated 110 ${ }^{\circ} \mathrm{C}$ oil bath, stirred at reflux for $20 \mathrm{~min}$, and then cooled to $23{ }^{\circ} \mathrm{C}$. The reaction was poured into aq. $\mathrm{HCl}(0.5 \mathrm{M}, 100 \mathrm{~mL})$, the layers were separated, and the aqueous layer was extracted with EtOAc $(3 \times 75 \mathrm{~mL})$. The combined organic layers were washed with sat. aq. $\mathrm{NaCl}(75 \mathrm{~mL})$, dried over $\mathrm{Na}_{2} \mathrm{SO}_{4}$, and concentrated under reduced pressure directly onto silica gel $(1.7 \mathrm{~g})$. The crude product was purified by flash column chromatography ( $8 \mathrm{~g}$ silica gel, 4:1 Hexanes:EtOAc $\rightarrow 2: 3$ Hexanes:EtOAc) to provide the corresponding carboxylic acid, which was carried crude to the next step.

To a suspension of the crude carboxylic acid prepared in the previous step (465 mg, 2.27 mmol, 1.00 equiv) in $\mathrm{PhMe}(20 \mathrm{~mL})$, was added aq. $\mathrm{HCl}(0.5 \mathrm{M}, 25 \mathrm{~mL})$. The reaction was placed in a preheated $110{ }^{\circ} \mathrm{C}$ oil bath and stirred at reflux for $2 \mathrm{~h}$ before being allowed to cool to $23{ }^{\circ} \mathrm{C}$. The reaction was poured into a biphasic mixture of $\mathrm{DI}_{2} \mathrm{O}(100 \mathrm{~mL})$ and $\mathrm{CH}_{2} \mathrm{Cl}_{2}(100$ $\mathrm{mL})$. The layers were separated, and the aqueous layer was extracted with $\mathrm{CH}_{2} \mathrm{Cl}_{2}(2 \times 100 \mathrm{~mL})$. The combined organic layers were dried over $\mathrm{MgSO}_{4}$ and concentrated under reduced pressure directly onto silica gel $(1 \mathrm{~g})$. The crude product was purified by flash column chromatography (5 g silica gel, 7:3 Hexanes:EtOAc) to provide pyrrolidinone $\mathbf{1 7 b}(299 \mathrm{mg}, 67 \%$ yield, 2 steps) as a 
viscous oil. Pyrrolidinone 17b: $\mathrm{R}_{\mathrm{f}} 0.22\left(1: 4\right.$ Hexanes:EtOAc); ${ }^{1} \mathrm{H}$ NMR $\left(500 \mathrm{MHz}, \mathrm{CDCl}_{3}\right) \delta$ $7.28-7.20(\mathrm{~m}, 1 \mathrm{H}), 6.85-6.70(\mathrm{~m}, 3 \mathrm{H}), 3.79(\mathrm{~s}, 3 \mathrm{H}), 3.62(\mathrm{t}, J=8.7 \mathrm{~Hz}, 1 \mathrm{H}), 3.51-3.36(\mathrm{~m}$, 2H), $2.93(\mathrm{~s}, 3 \mathrm{H}), 2.51(\mathrm{dtd}, J=12.8,8.5,3.9 \mathrm{~Hz}, 1 \mathrm{H}), 2.12(\mathrm{dq}, J=12.9,8.1 \mathrm{~Hz}, 1 \mathrm{H}) ;{ }^{13} \mathrm{C} \mathrm{NMR}$ $\left(125 \mathrm{MHz}, \mathrm{CDCl}_{3}\right) \delta 174.9,160.0,141.7,129.9,120.3,113.9,112.4,5$ 55.4, 48.2, 47.9, 30.3, 28.0; HRMS-APCI (m/z) [M + H] calcd for $\mathrm{C}_{12} \mathrm{H}_{16} \mathrm{NO}_{2}{ }^{+}, 206.1176$; found 206.1167.

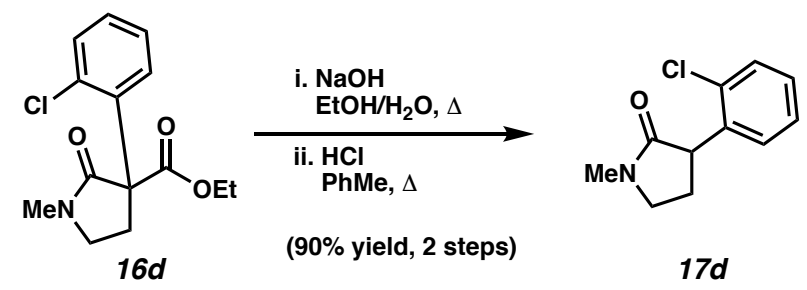

Pyrrolidinone 17d. To a solution of pyrrolidinone 16d (290 mg, $1.03 \mathrm{mmol}, 1.0$ equiv) in EtOH $(5 \mathrm{~mL})$, was added aq. $\mathrm{NaOH}(1 \mathrm{M}, 15 \mathrm{~mL})$. The reaction was placed in a preheated $110{ }^{\circ} \mathrm{C}$ oil bath, stirred at reflux for $45 \mathrm{~min}$, and then cooled to $23{ }^{\circ} \mathrm{C}$. Aq. $\mathrm{HCl}(2 \mathrm{M}, 15 \mathrm{~mL})$ was added followed by $\mathrm{PhMe}(20 \mathrm{~mL})$. The reaction was placed in a preheated $110^{\circ} \mathrm{C}$ oil bath and stirred at reflux for $2 \mathrm{~h}$ before being allowed to cool to $23{ }^{\circ} \mathrm{C}$. The reaction was poured into a biphasic mixture of DI $\mathrm{H}_{2} \mathrm{O}(100 \mathrm{~mL})$ and $\mathrm{CH}_{2} \mathrm{Cl}_{2}(100 \mathrm{~mL})$, the layers were separated, and the aqueous layer was extracted with $\mathrm{CH}_{2} \mathrm{Cl}_{2}(2 \times 100 \mathrm{~mL})$. The combined organic layers were dried over $\mathrm{MgSO}_{4}$ and concentrated under reduced pressure directly onto silica gel $(2.5 \mathrm{~g})$. The crude product was purified by flash column chromatography (15 g silica gel, 1:1 Hexanes:EtOAc $\rightarrow$ 1:3 Hexanes:EtOAc) to provide pyrrolidinone 17d (195 $\mathrm{mg}, 90 \%$ yield) as a glassy solid. Pyrrolidinone 17d: $\mathrm{R}_{\mathrm{f}} 0.40$ (EtOAc); ${ }^{1} \mathrm{H}$ NMR $\left(500 \mathrm{MHz}, \mathrm{CDCl}_{3}\right) \delta 7.42-7.33(\mathrm{~m}, 1 \mathrm{H}), 7.26-$ $7.16(\mathrm{~m}, 3 \mathrm{H}), 4.11(\mathrm{t}, J=9.2 \mathrm{~Hz}, 1 \mathrm{H}), 3.53-3.39(\mathrm{~m}, 2 \mathrm{H}), 2.97(\mathrm{~s}, 3 \mathrm{H}), 2.61$ (dddd, $J=13.4$, 9.4, 6.7, $4.3 \mathrm{~Hz}, 1 \mathrm{H}), 1.96(\mathrm{dq}, J=13.0,8.6 \mathrm{~Hz}, 1 \mathrm{H}) ;{ }^{13} \mathrm{C} \mathrm{NMR}\left(125 \mathrm{MHz}, \mathrm{CDCl}_{3}\right) \delta 174.3$, 138.1, 134.4, 129.8, 129.5, 128.4, 127.4, 47.7, 46.1, 30.3, 27.4; HRMS-APCI (m/z) $[\mathrm{M}+\mathrm{H}]^{+}$ calcd for $\mathrm{C}_{11} \mathrm{H}_{13} \mathrm{NOCl}^{+}, 210.0686$; found 210.0672 . 


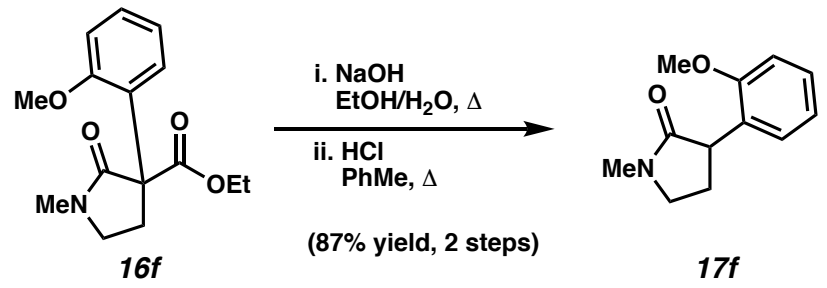

Pyrrolidinone 17f. To a solution of pyrrolidinone $\mathbf{1 6 f}$ (1.42 g, $5.10 \mathrm{mmol}, 1.0$ equiv) in $\mathrm{EtOH}$ $(10 \mathrm{~mL})$, was added aq. $\mathrm{NaOH}(1 \mathrm{M}, 17 \mathrm{~mL})$. The reaction was placed in a preheated $115^{\circ} \mathrm{C}$ oil bath, stirred at reflux for $15 \mathrm{~min}$, and then cooled to $23{ }^{\circ} \mathrm{C}$. To the reaction was added, aq. $\mathrm{HCl}(1$ M, $30 \mathrm{~mL})$ followed by $\mathrm{PhMe}(30 \mathrm{~mL})$. The reaction was placed in a preheated $115{ }^{\circ} \mathrm{C}$ oil bath and stirred at reflux for $3 \mathrm{~h}$ before being allowed to cool to $23{ }^{\circ} \mathrm{C}$. The reaction was poured into a biphasic mixture of $\mathrm{DI} \mathrm{H}_{2} \mathrm{O}(100 \mathrm{~mL})$ and $\mathrm{CH}_{2} \mathrm{Cl}_{2}(100 \mathrm{~mL})$, the layers were separated, and the aqueous layer was extracted with $\mathrm{CH}_{2} \mathrm{Cl}_{2}(2 \times 100 \mathrm{~mL})$. The combined organic layers were dried over $\mathrm{MgSO}_{4}$ and concentrated under reduced pressure. The crude product was purified by flash column chromatography (RediSep Gold $25 \mathrm{~g}$ silica gel, 3:7 Hexanes:EtOAc) to provide pyrrolidinone $\mathbf{1 7 f}$ (909 mg, 87\% yield) as a glassy solid. Pyrrolidinone 17f: $\mathrm{R}_{\mathrm{f}} 0.40$ (EtOAc); ${ }^{1} \mathrm{H}$ NMR (600 MHz, $\left.\mathrm{CDCl}_{3}\right) \delta 7.22(\mathrm{ddd}, J=8.2,7.5,1.7 \mathrm{~Hz}, 1 \mathrm{H}), 7.12(\mathrm{dd}, J=7.5,1.7 \mathrm{~Hz}, 1 \mathrm{H})$, $6.92(\mathrm{td}, J=7.4,1.2 \mathrm{~Hz}, 1 \mathrm{H}), 6.87(\mathrm{dd}, J=8.2,1.1 \mathrm{~Hz}, 1 \mathrm{H}), 3.91(\mathrm{t}, J=9.0 \mathrm{~Hz}, 1 \mathrm{H}), 3.80(\mathrm{~s}$, 3H), $3.48-3.35$ (m, 2H), 2.94 (s, 3H), 2.46 (dddd, $J=13.1,9.6,7.7,4.0 \mathrm{~Hz}, 1 \mathrm{H}), 2.00$ (dtd, $J=$ 12.8, 8.7, $7.5 \mathrm{~Hz}, 1 \mathrm{H}) ;{ }^{13} \mathrm{C} \mathrm{NMR}\left(125 \mathrm{MHz}, \mathrm{CDCl}_{3}\right) \delta 175.5,157.5,129.5,128.9,128.3,121.0$, 111.0, 55.7, 48.0, 43.7, 30.3, 27.1; HRMS-APCI $(\mathrm{m} / \mathrm{z})[\mathrm{M}+\mathrm{H}]^{+}$calcd for $\mathrm{C}_{12} \mathrm{H}_{16} \mathrm{NO}_{2}{ }^{+}$, 206.1176; found 206.1173. 

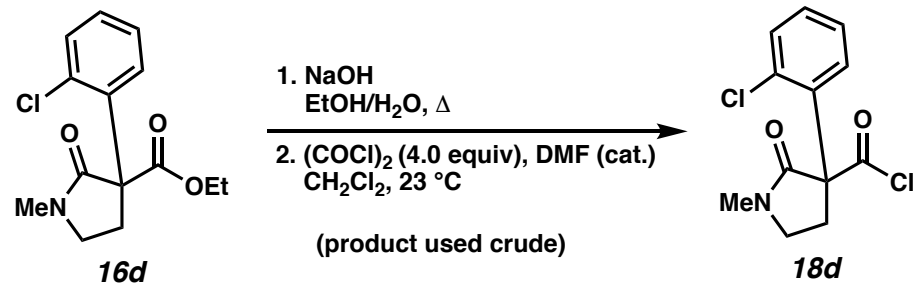

Acid Chloride 18d. To a solution of pyrrolidinone 16d (440 mg, $1.56 \mathrm{mmol}, 1.00$ equiv) in EtOH $(5 \mathrm{~mL})$, was added aq. $\mathrm{NaOH}(1 \mathrm{M}, 15 \mathrm{~mL})$. The reaction was placed in a preheated 115 ${ }^{\circ} \mathrm{C}$ oil bath, stirred at reflux until all solid had dissolved ( $\left.5 \mathrm{~min}\right)$, and then cooled to $23{ }^{\circ} \mathrm{C}$. The reaction mixture was poured into aq. $\mathrm{HCl}(0.5 \mathrm{M}, 50 \mathrm{~mL})$ and extracted with EtOAc $(3 \times 100$ $\mathrm{mL})$. The combined organic layers were washed with sat. aq. $\mathrm{NaCl}(100 \mathrm{~mL})$, dried over $\mathrm{Mg}_{2} \mathrm{SO}_{4}$, and concentrated under reduced pressure. The resultant crude carboxylic acid was carried on directly to the next step.

To neat crude carboxylic acid from the previous step was added one drop of DMF from a glass Pasteur pipette, followed by $\mathrm{CH}_{2} \mathrm{Cl}_{2}(16 \mathrm{~mL})$ via syringe. Oxalyl chloride $(0.54 \mathrm{~mL}, 6.2$ mmol, 4.0 equiv) was then added dropwise over $1 \mathrm{~min}$. The reaction was stirred at $23{ }^{\circ} \mathrm{C}$ for $16 \mathrm{~h}$ and then concentrated under reduced pressure. The resultant oil was dissolved in PhMe (10 mL) and concentrated under reduced pressure (x2). The crude oil was then put under vacuum $(<1$ mbar) for $1 \mathrm{~h}$. Crude acid chloride $\mathbf{1 8 d}$ was used immediately without further purification.

Note 1: It is critical that this set up is kept both anhydrous and that the oxalyl chloride is fully removed. Each time the acid chloride was concentrated under rotary evaporation (both from $\mathrm{CH}_{2} \mathrm{Cl}_{2}$ and then from PhMe) the water bath was maintained at $50{ }^{\circ} \mathrm{C}$ on full vacuum $(\sim 15$ mbar) for $>15 \mathrm{~min}$. After this, it is recommended that the oil be put under high vacuum for $>1$ $h$. 
Note 2: In order to ensure that undue water is not introduced between rotary evaporations, the rotary evaporator is backfilled with a balloon of dry Ar.
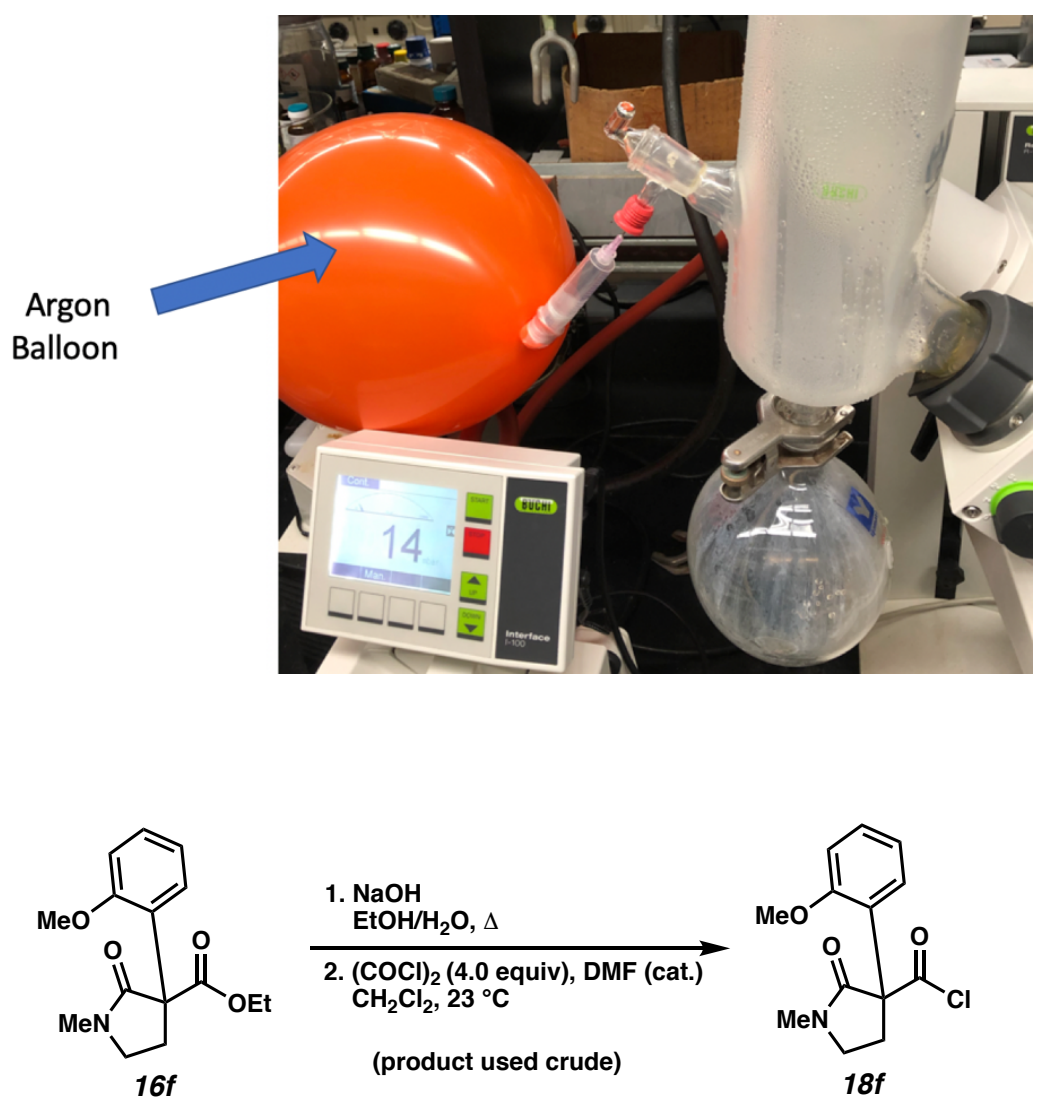

Acid Chloride 18f. To a solution of pyrrolidinone $16 f(2.0 \mathrm{~g}, 7.2 \mathrm{mmol}, 1.0$ equiv) in EtOH (30 $\mathrm{mL})$, was added aq. $\mathrm{NaOH}(1 \mathrm{M}, 50 \mathrm{~mL})$. The reaction was placed in a preheated $105{ }^{\circ} \mathrm{C}$ oil bath, stirred at reflux for $15 \mathrm{~min}$, and then cooled to $23^{\circ} \mathrm{C}$. The reaction mixture was poured into aq. $\mathrm{HCl}(2 \mathrm{M}, 60 \mathrm{~mL})$ and extracted with $\mathrm{CH}_{2} \mathrm{Cl}_{2}(3 \times 100 \mathrm{~mL})$. The combined organic layers were dried over $\mathrm{Mg}_{2} \mathrm{SO}_{4}$, and then concentrated under reduced pressure. The resultant crude carboxylic acid was carried on directly to the next step.

To neat crude carboxylic acid from the previous step (926 mg, $3.71 \mathrm{mmol}, 1.0$ equiv), was added one drop of DMF from a glass Pasteur pipette followed by $\mathrm{CH}_{2} \mathrm{Cl}_{2}(35 \mathrm{~mL})$ via syringe. Oxalyl chloride (1.27 mL, $14.9 \mathrm{mmol}, 4.0$ equiv) was then added dropwise over $1 \mathrm{~min}$. The reaction was stirred at $23{ }^{\circ} \mathrm{C}$ for $1 \mathrm{~h}$ and then concentrated under reduced pressure. The 
resultant oil was dissolved in PhMe $(20 \mathrm{~mL})$ and concentrated under reduced pressure (x2). The crude oil was then put under vacuum ( $<1$ mbar) for $1 \mathrm{~h}$. Crude acid chloride $\mathbf{1 8 f}$ was used immediately without further purification.

See the preparation of $\mathbf{1 8 d}$ for experimental notes.

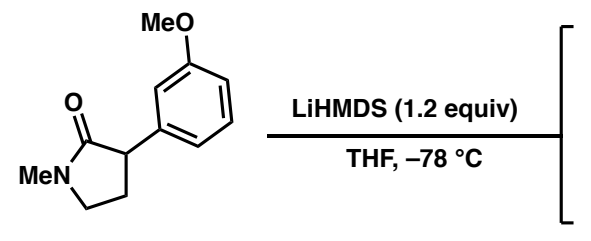

$17 b$

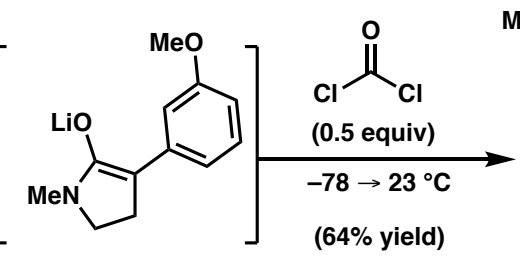

$(64 \%$ yield $)$

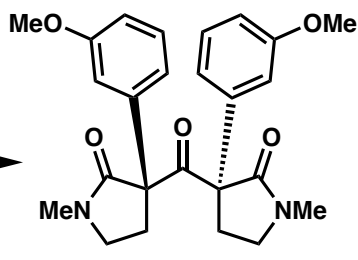

$11 b$

Ketone 11b. A solution of amide $\mathbf{1 7 b}(470 \mathrm{mg}, 1.41 \mathrm{mmol}, 1.0$ equiv) in THF (10 mL) was placed in $\mathrm{a}-78^{\circ} \mathrm{C}$ bath and stirred for $5 \mathrm{~min}$. A solution of LiHMDS (270 mg, $1.61 \mathrm{mmol}, 1.15$ equiv) in THF ( $1 \mathrm{~mL})$ was added dropwise over 5 min and the reaction was stirred for 45 min. Phosgene (15 wt\% in PhMe, $0.50 \mathrm{~mL}, 0.70 \mathrm{mmol}, 0.5$ equiv) was added dropwise over $5 \mathrm{~min}$ and the reaction was immediately transferred to a $0{ }^{\circ} \mathrm{C}$ bath and stirred for $20 \mathrm{~min}$. The mixture was then quenched by the addition of aq. $\mathrm{HCl}(0.1 \mathrm{M}, 10 \mathrm{~mL})$ and the aqueous layer was extracted with $\mathrm{CH}_{2} \mathrm{Cl}_{2}(2 \times 75 \mathrm{~mL})$. The combined organic layers were dried over $\mathrm{MgSO}_{4}$ and concentrated under reduced pressure directly gel $(0.5 \mathrm{~g})$. The crude product was purified by flash column chromatography (5 g silica gel, $\mathrm{CH}_{2} \mathrm{Cl}_{2} \rightarrow 7: 3 \mathrm{CH}_{2} \mathrm{Cl}_{2}$ :EtOAc) to provide ketone 11b (198 mg, 64\% yield) as a viscous oil. Ketone 11b: $\mathrm{R}_{\mathrm{f}} 0.20$ (1:4 Hexanes:EtOAc); ${ }^{1} \mathrm{H}$ NMR (500 $\left.\mathrm{MHz}, \mathrm{CDCl}_{3}\right) \delta 7.28-7.17(\mathrm{~m}, 2 \mathrm{H}), 6.84-6.74(\mathrm{~m}, 6 \mathrm{H}), 3.77(\mathrm{~s}, 6 \mathrm{H}), 3.37-3.25(\mathrm{~m}, 4 \mathrm{H}), 3.11$ - $3.05(\mathrm{~m}, 2 \mathrm{H}), 2.86(\mathrm{~s}, 6 \mathrm{H}), 1.95-1.88(\mathrm{~m}, 2 \mathrm{H}) ;{ }^{13} \mathrm{C} \mathrm{NMR}\left(125 \mathrm{MHz}, \mathrm{CDCl}_{3}\right) \delta 200.49$, $171.08,159.91,140.52,129.70,119.78,113.32,112.88,67.84,55.33,46.69,33.12,30.65$; HRMS-APCI (m/z) $[\mathrm{M}+\mathrm{H}]^{+}$calcd for $\mathrm{C}_{25} \mathrm{H}_{29} \mathrm{~N}_{2} \mathrm{O}_{5}{ }^{+}$, 437.2071; found 437.2053. 

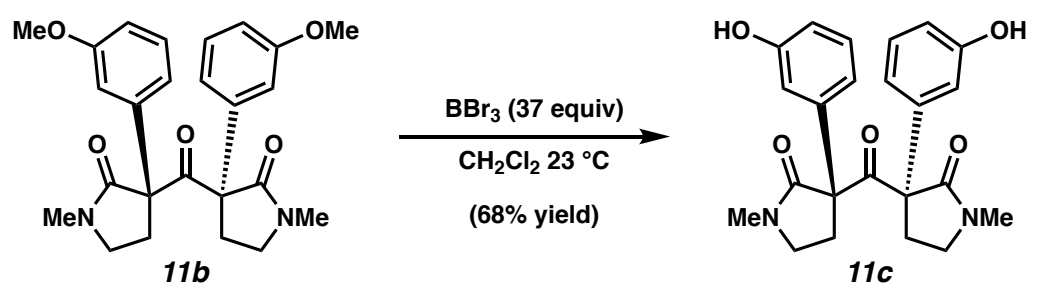

Ketone 11c. To a solution of ketone $11 \mathbf{b}\left(297 \mathrm{mg}, 0.68 \mathrm{mmol}, 1.00\right.$ equiv) in $\mathrm{CH}_{2} \mathrm{Cl}_{2}(50 \mathrm{~mL})$, was added $\mathrm{BBr}_{3}(2.4 \mathrm{~mL}, 6.3 \mathrm{~g}, 25 \mathrm{mmol}, 37$ equiv) dropwise over $3 \mathrm{~min}$. The reaction mixture was stirred at $23{ }^{\circ} \mathrm{C}$ for $50 \mathrm{~min}$ and then cooled to $-78{ }^{\circ} \mathrm{C}$. The reaction was quenched by the addition of a mixture of $\mathrm{Et}_{3} \mathrm{~N}(4.5 \mathrm{~mL})$ in $\mathrm{MeOH}(15 \mathrm{~mL})$ dropwise over 1 min, warmed $23{ }^{\circ} \mathrm{C}$, and then poured into EtOAc $(50 \mathrm{~mL})$. The mixture was washed with sat. aq. $\mathrm{NaHCO}_{3}(40 \mathrm{~mL})$ followed by sat. aq. $\mathrm{NaCl}(40 \mathrm{~mL})$, dried over $\mathrm{Na}_{2} \mathrm{SO}_{4}$, and concentrated under reduced pressure directly onto silica gel (1.2 g). The crude product was purified by flash column chromatography $(10 \mathrm{~g}$ silica gel, $3: 7$ Hexanes:EtOAc $\rightarrow$ EtOAc) to provide ketone $11 \mathrm{c}(189 \mathrm{mg}, 68 \%$ yield $)$ as a white solid. Crystals suitable for X-ray diffraction studies (CCDC 2006463) were obtained by slow evaporation from MeOH. Ketone 11c: $\mathrm{R}_{\mathrm{f}} 0.49$ (EtOAc); ${ }^{1} \mathrm{H}$ NMR $\left(500 \mathrm{MHz}\right.$, Methanol- $\left.d_{4}\right)$ $\delta 7.17(\mathrm{t}, J=7.9 \mathrm{~Hz}, 2 \mathrm{H}), 6.72(\mathrm{dd}, J=8.1,2.3 \mathrm{~Hz}, 2 \mathrm{H}), 6.67-6.58(\mathrm{~m}, 4 \mathrm{H}), 3.28-3.20(\mathrm{~m}$, 4H), $3.17-3.07(\mathrm{~m}, 2 \mathrm{H}), 2.86(\mathrm{~s}, 6 \mathrm{H}), 1.99-1.88(\mathrm{~m}, 2 \mathrm{H}) ;{ }^{13} \mathrm{C}$ NMR (125 MHz, Methanol- $\left.d_{4}\right) \delta$ 200.4, 171.7, 157.49, 140.0, 129.4, 117.9, 114.1, 114.0, 67.9, 46.2, 32.9, 29.2; HRMS-APCI $(\mathrm{m} / \mathrm{z})[\mathrm{M}+\mathrm{H}]^{+}$calcd for $\mathrm{C}_{23} \mathrm{H}_{25} \mathrm{~N}_{2} \mathrm{O}_{5}{ }^{+}, 409.1758$; found 409.1742 . 


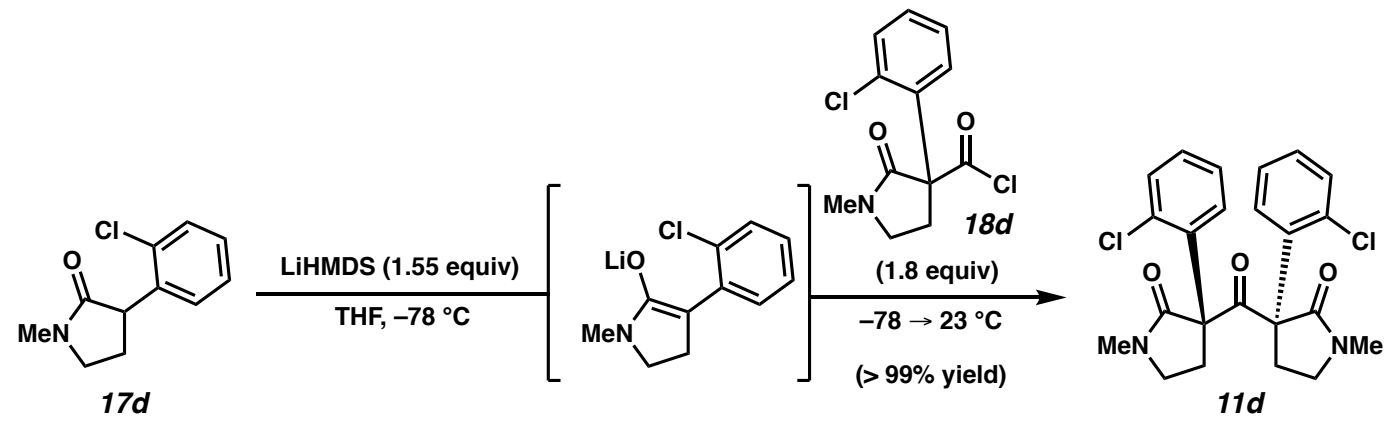

Ketone 11d. A solution of pyrrolidinone 17d (179 mg, $0.853 \mathrm{mmol}, 1.00$ equiv) in THF (5 mL) was added dropwise over $5 \mathrm{~min}$ to a pre-cooled $-78^{\circ} \mathrm{C}$ solution of LiHMDS $(6.32 \mathrm{~mL}, 221 \mathrm{mg}$, $1.32 \mathrm{mmol}, 1.55$ equiv) in THF $(6.32 \mathrm{~mL})$. The mixture was allowed to stir for $1 \mathrm{~h}$ before acid chloride 18d (420 mg, $1.6 \mathrm{mmol}, 1.8$ equiv) was added dropwise over $5 \mathrm{~min}$. The reaction was then removed from the $-78{ }^{\circ} \mathrm{C}$ bath and stirred at $23{ }^{\circ} \mathrm{C}$ for $2 \mathrm{~h}$ before being poured into a mixture of sat. aq. $\mathrm{NaCl}(50 \mathrm{~mL})$ and aq. $\mathrm{HCl}(1 \mathrm{M}, 50 \mathrm{~mL})$. The layers were separated and the aqueous layer was extracted with $\mathrm{CH}_{2} \mathrm{Cl}_{2}(3 \times 100 \mathrm{~mL})$. The combined organic layers were dried over $\mathrm{MgSO}_{4}$ and concentrated under reduced pressure directly onto silica gel $(2.5 \mathrm{~g})$. The crude product was purified by flash column chromatography $\left(15 \mathrm{~g}\right.$ silica gel, $\mathrm{CH}_{2} \mathrm{Cl}_{2} \rightarrow$ 9:1 $\mathrm{CH}_{2} \mathrm{Cl}_{2}$ :EtOAc) to provide ketone $\mathbf{1 1 d}(387 \mathrm{mg},>99 \%$ yield) as a white solid. Crystals suitable for X-ray diffraction studies (CCDC 2006461) were obtained using slow evaporation from a mixture of $\mathrm{CH}_{2} \mathrm{Cl}_{2} / \mathrm{Hexanes}$. Ketone 11d: mp: $151.0-151.1{ }^{\circ} \mathrm{C} ; \mathrm{R}_{\mathrm{f}} 0.56$ (EtOAc); ${ }^{1} \mathrm{H}$ NMR $(500$ $\left.\mathrm{MHz}, \mathrm{CDCl}_{3}\right) \delta 7.72(\mathrm{dd}, J=7.1,2.5 \mathrm{~Hz}, 2 \mathrm{H}), 7.47-7.36(\mathrm{~m}, 2 \mathrm{H}), 7.24-7.19(\mathrm{~m}, 4 \mathrm{H}), 3.57$ $(\mathrm{ddd}, J=13.1,8.2,4.8 \mathrm{~Hz}, 2 \mathrm{H}), 3.36(\mathrm{td}, J=8.8,5.5 \mathrm{~Hz}, 2 \mathrm{H}), 3.13(\mathrm{td}, J=8.6,4.7 \mathrm{~Hz}, 2 \mathrm{H}), 2.89$ $(\mathrm{s}, 6 \mathrm{H}), 2.31(\mathrm{ddd}, J=13.4,8.0,5.6 \mathrm{~Hz}, 2 \mathrm{H}) ;{ }^{13} \mathrm{C} \mathrm{NMR}\left(125 \mathrm{MHz}, \mathrm{CDCl}_{3}\right) \delta 197.4,171.1$, $137.4,134.0,131.9,130.6,129.0,126.8,69.3,46.9,30.9,30.8 ;$ HRMS-APCI $(\mathrm{m} / \mathrm{z})[\mathrm{M}+\mathrm{H}]^{+}$ calcd for $\mathrm{C}_{23} \mathrm{H}_{23} \mathrm{~N}_{2} \mathrm{O}_{3} \mathrm{Cl}_{2}^{+}$, 445.1086; found 445.1086. 


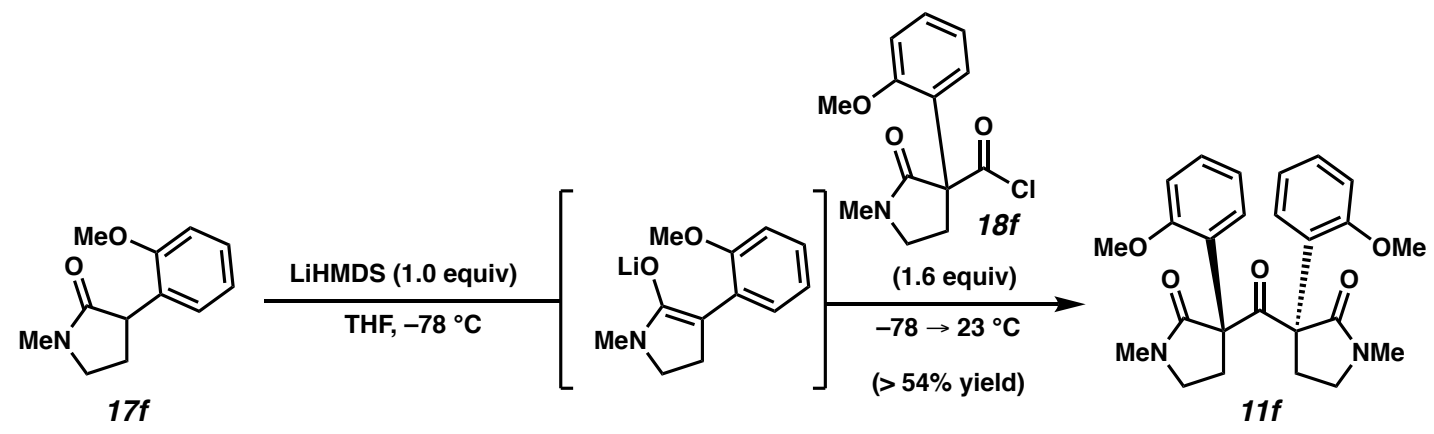

Ketone 11f. A solution of amide $17 \mathbf{f}(470 \mathrm{mg}, 2.29 \mathrm{mmol}, 1.00$ equiv) in THF (24 mL) was placed in $\mathrm{a}-78^{\circ} \mathrm{C}$ bath and stirred for $5 \mathrm{~min}$. A solution of LiHMDS (1 M in THF, $2.29 \mathrm{~mL}, 383$ mg, $2.29 \mathrm{mmol}, 1.00$ equiv) was added dropwise over $5 \mathrm{~min}$ and the mixture was then stirred for 45 min. A solution of acid chloride $\mathbf{1 8 f}$ (990 mg, $3.7 \mathrm{mmol}, 1.6$ equiv) in THF (10 mL) was added dropwise over $5 \mathrm{~min}$, the reaction was removed from the $-78{ }^{\circ} \mathrm{C}$ bath, and then stirred at $23{ }^{\circ} \mathrm{C}$ for $15 \mathrm{~min}$. The reaction was then poured into aq. $\mathrm{HCl}(0.5 \mathrm{M}, 25 \mathrm{~mL})$, the layers were separated, and the aqueous layer was extracted with $\mathrm{CH}_{2} \mathrm{Cl}_{2}(2 \times 75 \mathrm{~mL})$. The combined organic layers were dried over $\mathrm{MgSO}_{4}$ and concentrated under reduced pressure directly onto silica gel (2 g). The crude product was then purified by flash column chromatography (15 g silica gel, 9:1 $\mathrm{CH}_{2} \mathrm{Cl}_{2}$ :EtOAc $\rightarrow$ 7:3 $\mathrm{CH}_{2} \mathrm{Cl}_{2}:$ EtOAc) to provide ketone $11 \mathrm{f}$ (543 $\mathrm{mg}, 54 \%$ yield) as a white solid. Crystals suitable for X-ray diffraction studies (CCDC 2006463) were obtained as follows: pure ketone $(30 \mathrm{mg})$ was dissolved in minimal $\mathrm{CHCl}_{3}(\sim 2 \mathrm{~mL}) . n \mathrm{Hexane}(\sim 6 \mathrm{~mL})$ was layered on top of $\mathrm{CHCl}_{3}$ solution and the layers were allowed to slowly diffuse together over 3 days. Ketone 11f: mp: $249.2-251.0{ }^{\circ} \mathrm{C} ; \mathrm{R}_{\mathrm{f}} 0.20$ (1:4 Hexanes:EtOAc); ${ }^{1} \mathrm{H}$ NMR $\left(500 \mathrm{MHz}, \mathrm{CDCl}_{3}\right) \delta 7.36(\mathrm{dd}$, $J=7.7,1.7 \mathrm{~Hz}, 2 \mathrm{H}), 7.30(\mathrm{ddd}, J=8.2,7.4,1.7 \mathrm{~Hz}, 2 \mathrm{H}), 6.95(\mathrm{dd}, J=8.2,1.1 \mathrm{~Hz}, 2 \mathrm{H}), 6.92(\mathrm{td}$, $J=7.6,1.2 \mathrm{~Hz}, 2 \mathrm{H}), 3.85(\mathrm{~s}, 6 \mathrm{H}), 3.37-3.24(\mathrm{~m}, 4 \mathrm{H}), 3.15-3.05(\mathrm{~m}, 2 \mathrm{H}), 2.87(\mathrm{~s}, 6 \mathrm{H}), 2.26-$ $2.12(\mathrm{~m}, 2 \mathrm{H}) ;{ }^{13} \mathrm{C} \mathrm{NMR}\left(125 \mathrm{MHz}, \mathrm{CDCl}_{3}\right) \delta 200.6,172.1,157.0,129.4,129.2,128.9,120.4$, 112.0, 67.9, 55.4, 47.2, 31.3, 30.6; HRMS-APCI $(\mathrm{m} / \mathrm{z})[\mathrm{M}+\mathrm{H}]^{+}$calcd for $\mathrm{C}_{25} \mathrm{H}_{29} \mathrm{~N}_{2} \mathrm{O}_{5}^{+}$, 437.2071; found 437.2028. 


\subsubsection{Photochemistry of Ketones 11 .}
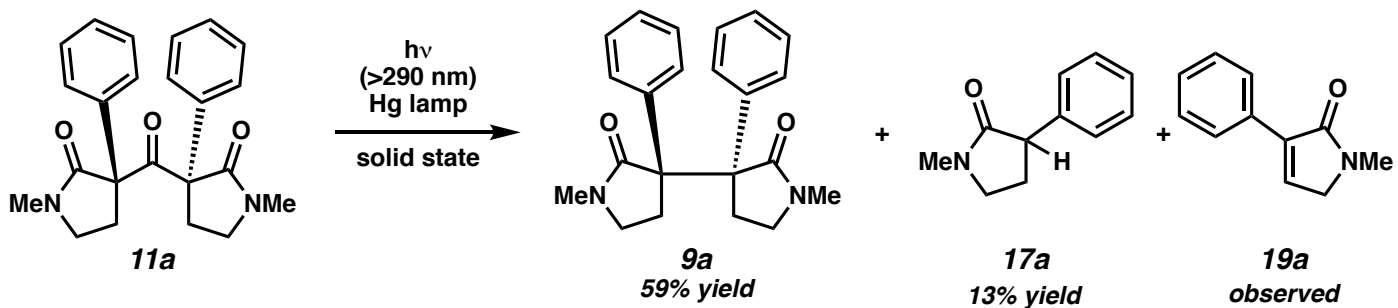

Bis(pyrrolidinone) 9a. Ketone 11a $(\sim 1 \mathrm{~g})$ was dissolved in $\mathrm{CH}_{2} \mathrm{Cl}_{2}(\sim 50 \mathrm{~mL})$ and Hexanes $(\sim 30$ $\mathrm{mL}$ ) were added until the mixture became cloudy. This was allowed to evaporate over $\sim 16 \mathrm{~h}$. Once crystals had formed, the residual solvent was removed using a glass Pasteur pipette. The resultant crystalline solid was put under high vacuum ( $<1 \mathrm{mbar})$ for $1 \mathrm{~h}$. A sample of crystalline 11a (204mg, $0.542 \mathrm{mmol}, 1.0$ equiv) was placed between glass microscope slides. The slides were rubbed together for 10 seconds to crush 11 a into a thin layer of crystalline powder (Note 1). The glass slides were then clamped together using two binder clips. The solid sample was irradiated with a $450 \mathrm{~W}$ medium pressure Hg Hanovia UV lamp placed inside a water-cooled immersion-well Pyrex filter (Ace Glass, model 7857-05, $\lambda \geq 290 \mathrm{~nm} ; 53 \mathrm{~mm}$ external diameter, $220 \mathrm{~mm}$ full length, $150 \mathrm{~mm}$ depth) for $7 \mathrm{~h}$. At this time, the sample was flipped over (to expose the other side of the solid to light) and then irradiated for another $9 \mathrm{~h}$. The binder clips were then removed and a metal spatula was used to scrape the solid off of the glass slides into a vial. The slides and spatula were then rinsed with $\mathrm{CDCl}_{3}(\sim 15 \mathrm{~mL})$ and the combined organics were concentrated under reduced pressure. The crude product was purified by flash column chromatography (24 g RediSep Gold, $\mathrm{CH}_{2} \mathrm{Cl}_{2} \rightarrow 1: 1 \mathrm{CH}_{2} \mathrm{Cl}_{2}$ :EtOAc) to give a bis(pyrrolidinone) 9a (111 mg, 59\% yield) and pyrrolidinone 17 (12.5 mg, 13\% yield) (Note 2). Characterization data for 9a and 17a matched those previously reported in the literature. ${ }^{\text {Error! Bookmark not defined. }}$ 


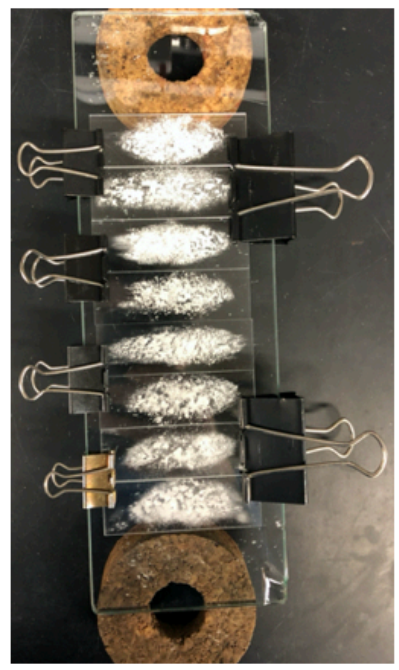

Before Irradiation

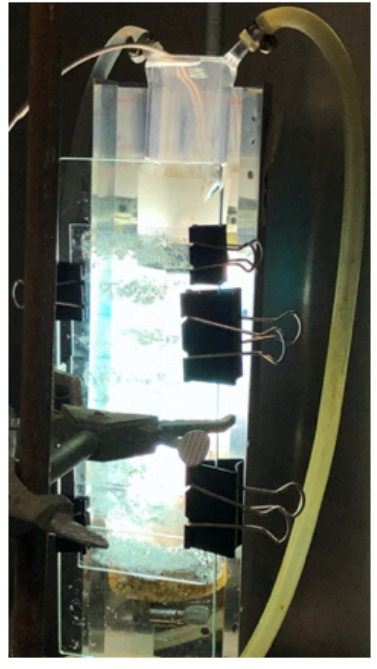

During Irradiation

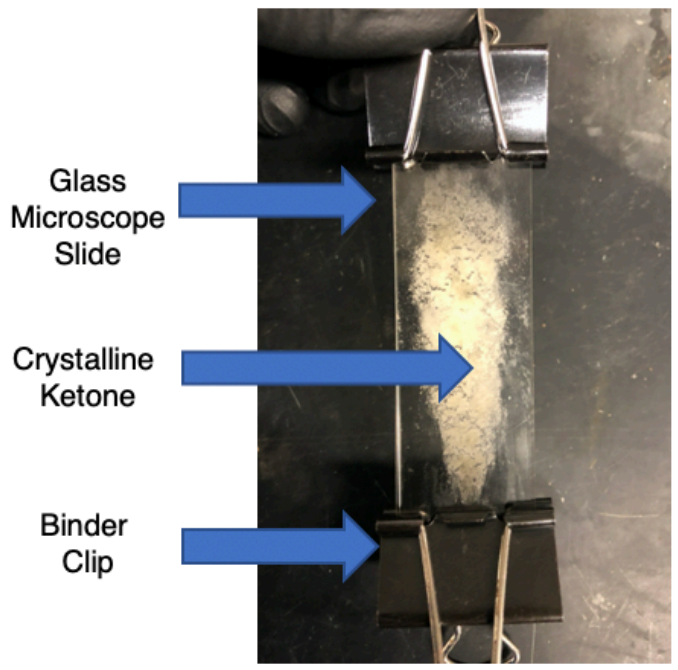

After Irradiation

Note 1: It is critical that the solid is crushed into a very thin layer to ensure adequate light penetration. In order to prevent overloading, several slides are irradiated in parallel w/20-30 mg of substrate between each pair of slides.

Note 2: Column chromatography is not sufficient to completely remove residual 17 a from $\mathbf{9 a}$. In order to completely purify $\mathbf{9 a}$ the partially pure material from the flash column is subjected to the following recrystallization conditions: Semi-pure 9 (oil) is dissolved in minimal Et $t_{2} O(\sim 10$ $m L$ per $100 \mathrm{mg}$ of semi-pure 9a) and is placed in a $-20{ }^{\circ} \mathrm{C}$ freezer for $1 \mathrm{~h}$. Mother liquor is removed with a Pasteur pipette and the resultant crystals are then rinsed with minimal $-20{ }^{\circ} \mathrm{C}$ $\mathrm{Et}_{2} \mathrm{O}(\sim 1 \mathrm{~mL})$. The mother liquor is then concentrated and resubjected to the same crystallization conditions (1x). 
General Procedure A (Photochemistry of 11c is used as an example).
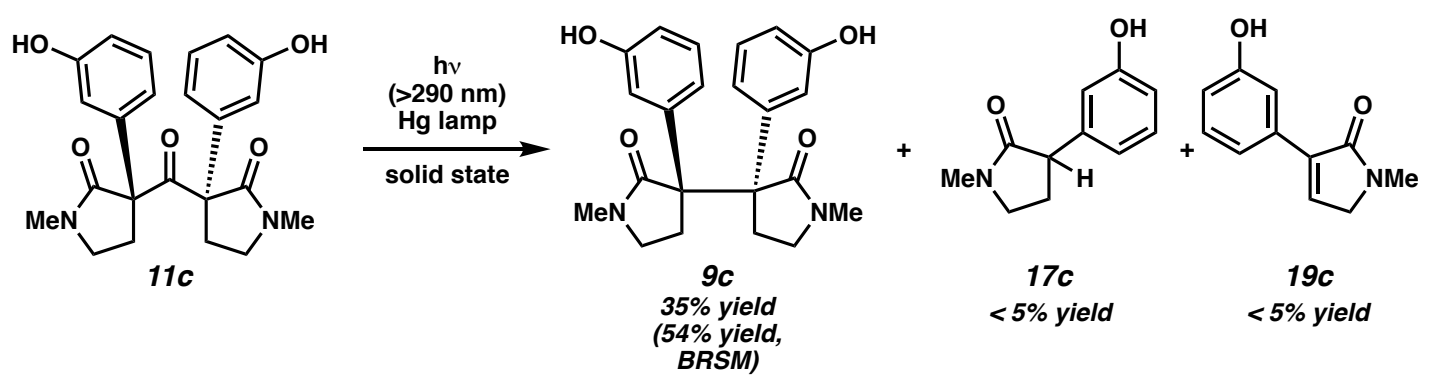

Bis(pyrrolidinone) 9c. Ketone 11c (100-150 mg) was dissolved in $\mathrm{MeOH}(\sim 10 \mathrm{~mL})$. This was allowed to evaporate over $\sim 16 \mathrm{~h}$. A small sample of crystalline 11c $(22.7 \mathrm{mg}, 55.7 \mu \mathrm{mol}, 1.00$ equiv) was placed between glass microscope slides. The slides were rubbed together for 10 seconds to crush 11c into a thin layer of crystalline powder (Note 1). The two glass slides were then clamped together using two binder clips. The solid sample was irradiated with a $450 \mathrm{~W}$ medium pressure Hg Hanovia UV lamp placed inside a water-cooled immersion-well Pyrex filter (Ace Glass, model 7857-05, $\lambda \geq 290 \mathrm{~nm} ; 53 \mathrm{~mm}$ external diameter, $220 \mathrm{~mm}$ full length, $150 \mathrm{~mm}$ depth) for $14 \mathrm{~h}$ (see Note 3 for reaction monitoring). At this time, the sample was flipped over (to expose the other side of the solid to light) and then irradiated for another $12 \mathrm{~h}$. The binder clips were then removed and a metal spatula was used to scrape the solid off of the glass slides into a vial. The slides and spatula were then rinsed with $\mathrm{CDCl}_{3}(\sim 15 \mathrm{~mL})$ and the resultant solution was concentrated under reduced pressure to give bis(pyrrolidinone) $9 \mathrm{c}$ (7.46 $\mathrm{mg}, 35 \%$ yield, $54 \%$ yield based on recovered starting material). (Yield determined by ${ }^{1} \mathrm{H}$ QNMR with dimethyl terephthalate as the external standard). Bis(pyrrolidinone) 9c: $\mathrm{R}_{\mathrm{f}} 0.49$ (EtOAc); ${ }^{1} \mathrm{H}$ NMR (500 MHz, Methanol- $\left.d_{4}\right) \delta 7.10(\mathrm{t}, J=7.9 \mathrm{~Hz}, 2 \mathrm{H}), 6.76(\mathrm{t}, J=2.2 \mathrm{~Hz}, 2 \mathrm{H}), 6.73$ (ddd, $J=8.0,2.4$, $0.8 \mathrm{~Hz}, 2 \mathrm{H}), 6.69$ (ddd, $J=7.8,1.7,0.7 \mathrm{~Hz}, 2 \mathrm{H}), 3.21-3.13(\mathrm{~m}, 2 \mathrm{H}), 2.91-2.82(\mathrm{~m}, 2 \mathrm{H}), 2.80$ (s, 6H), $1.79(\mathrm{dd}, J=12.4,5.5 \mathrm{~Hz}, 2 \mathrm{H}) ;{ }^{13} \mathrm{C} \mathrm{NMR}\left(125 \mathrm{MHz}\right.$, Methanol- $\left.d_{4}\right) \delta$ 178.0, 158.0, 
139.3, 129.6, 121.4, 117.4, 115.5, 57.1, 46.8, 30.9, 30.3; HRMS-APCI $(\mathrm{m} / \mathrm{z})[\mathrm{M}+\mathrm{H}]^{+}$calcd for $\mathrm{C}_{22} \mathrm{H}_{25} \mathrm{~N}_{2} \mathrm{O}_{4}{ }^{+}, 381.1809$; found 318.1800 .

One methylene proton is obscured by residual $\mathrm{MeOH}-\mathrm{d}_{4}$ signal but is inferred by HSQC spectrum.

Note 1: It is critical that the solid is crushed into a very thin layer to ensure adequate light penetration. In order to prevent overloading, no more than $14 \mathrm{mg}$ is placed between two slides. For larger scale reactions, several slides are run in parallel w/ 10-15 mg of substrate between each pair of slides.

Note 2: The 450W Hg lamp produces significant heat. This is mitigated by the jacket of cooling water and fans to circulate warm air out of the box containing the irradiation setup.

Note 3: This particular reaction was not monitored by TLC in order to ensure accurate yield determination. In general, to monitor the reaction by TLC, a very small aliquot $(<0.1 \mathrm{mg})$ of solid is removed with the tip of a glass Pasteur pipette. This solid is then dissolved in $\sim 1$ drop of $\mathrm{MeOH}$ and analyzed by TLC.

Note 4: While some of the mass balance is attributed to unidentified decomposition products, a substantial amount of insoluble yellow solid is produced. The identity of this material is unknown.

Note 5: In order to ensure that the crystal polymorph being irradiated was the same as the polymorph observed in the X-ray crystal structure, PXRD data was collected from the crystalline powder prior to irradiation. 

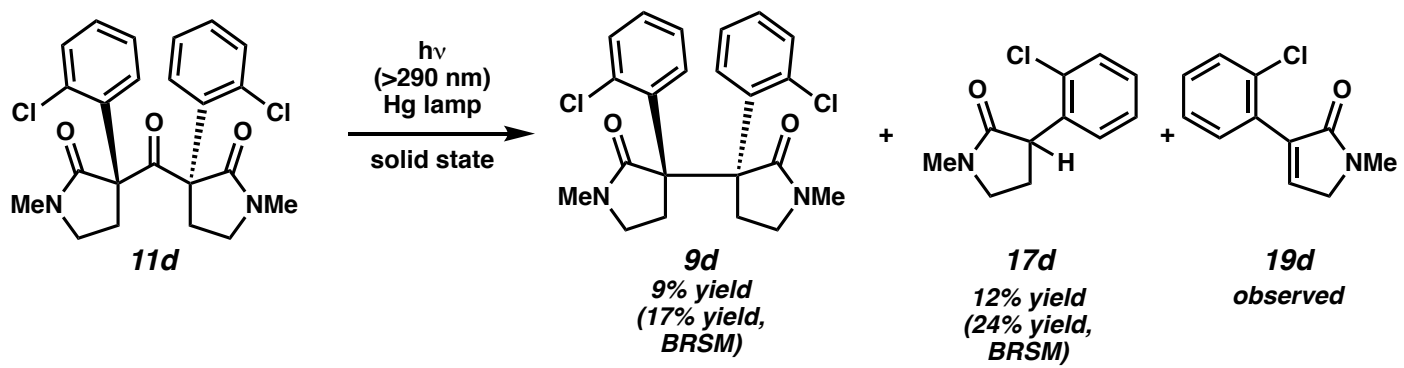

Bis(pyrrolidinone) 9d. Following General Procedure A using ketone 11d (39.3 mg, 73.5 umol, 1.00 equiv) afforded bis(pyrrolidinone) 9d (5.60 mg, 9\% yield, 17\% yield based on recovered starting material) and pyrrolidinone 17d $(3.80 \mathrm{mg}, 12 \%$ yield, $24 \%$ yield based on recovered starting material). (Yields determined by ${ }^{1} \mathrm{H}$ QNMR with dimethyl terephthalate as the external standard). Bis(pyrrolidinone) 9d: $\mathrm{R}_{\mathrm{f}} 0.25$ (1:1 Hexanes:EtOAc); ${ }^{1} \mathrm{H}$ NMR $\left(500 \mathrm{MHz}, \mathrm{CDCl}_{3}\right) \delta$ $7.43(\mathrm{dd}, J=8.0,1.5 \mathrm{~Hz}, 2 \mathrm{H}), 7.23(\mathrm{~d}, J=8.1 \mathrm{~Hz}, 2 \mathrm{H}), 7.16(\mathrm{td}, J=7.7,1.6 \mathrm{~Hz}, 2 \mathrm{H}), 7.01(\mathrm{td}, J$ $=7.9,1.5 \mathrm{~Hz}, 2 \mathrm{H}), 3.58(\mathrm{td}, J=9.0,4.8 \mathrm{~Hz}, 2 \mathrm{H}), 3.50-3.26(\mathrm{~m}, 4 \mathrm{H}), 2.81(\mathrm{~s}, 6 \mathrm{H}), 2.62(\mathrm{ddd}, J$ $=13.1,10.2,4.8 \mathrm{~Hz}, 2 \mathrm{H}) ;{ }^{13} \mathrm{C} \mathrm{NMR}\left(125 \mathrm{MHz}, \mathrm{CDCl}_{3}\right) \delta 173.4,140.1,134.7,134.3,132.23$, 128.2, 124.9, 59.4, 48.1, 30.7, 30.4; HRMS-APCI $(\mathrm{m} / \mathrm{z})[\mathrm{M}+\mathrm{H}]^{+}$calcd for $\mathrm{C}_{22} \mathrm{H}_{23} \mathrm{~N}_{2} \mathrm{O}_{2} \mathrm{Cl}_{2}{ }^{+}$, 417.1131; found 417.1117.

Note 1: Prior to conducting the solid-state photodecarbonylation, 11d was crystallized as follows: An amorphous sample of 11d ( 100 mg) was dissolved in minimal $\mathrm{Et}_{2} \mathrm{O}(\sim 50 \mathrm{~mL})$ and then sonicated until the solution became cloudy (due to precipitation of crystals). The sample was allowed to evaporate under ambient conditions and the resultant white powder was put under high vacuum (<1 mbar) for 1 h to ensure complete removal of the solvent.

Note 2: While some of the mass balance is attributed to disproportionation and unidentified decomposition products, a substantial amount of insoluble yellow solid is produced. The identity of this material is unknown. 


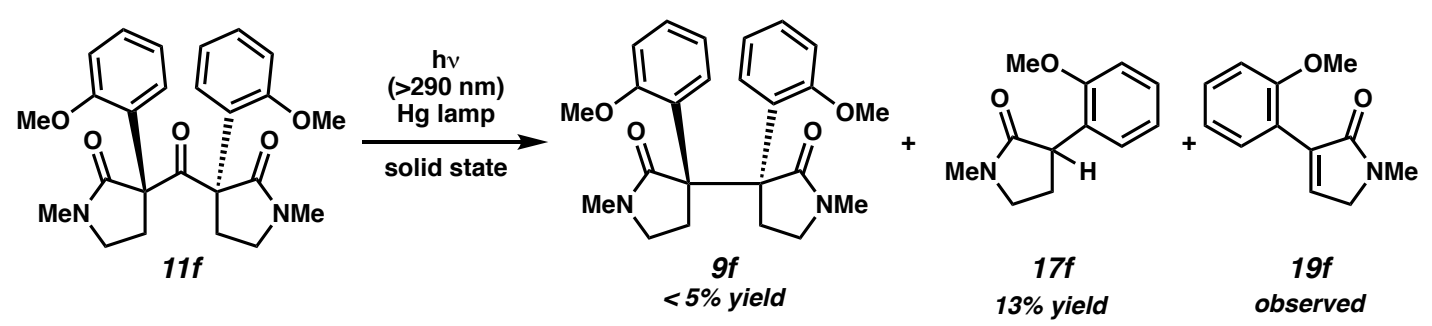

Photochemistry of 11f. Ketone 11f $(100-150 \mathrm{mg})$ was dissolved in $\mathrm{CH}_{2} \mathrm{Cl}_{2}(\sim 15 \mathrm{~mL})$ and Hexanes $(\sim 5 \mathrm{~mL})$ were added until the mixture became cloudy. This was allowed to evaporate over $\sim 16 \mathrm{~h}$. Once crystals had formed, the residual solvent was removed using a glass Pasteur pipette. The resultant crystalline solid was put under high vacuum $(<1 \mathrm{mbar})$ for $1 \mathrm{~h}$. Crystalline $11 \mathrm{f}$ (48.8 $\mathrm{mg}, 0.111 \mathrm{mmol}, 1.00$ equiv) was split into two portions and each was added to a separate 4-dram vial (Note 1). To each vial, an aqueous solution of SDS $(0.7 \mathrm{mg} / \mathrm{mL}, 10 \mathrm{~mL})$ was added in one portion and the suspension was sonicated for $5 \mathrm{~min}$ at $23{ }^{\circ} \mathrm{C}$ (Note 2). The vials were equipped with stirbars, sealed with screwcaps, and irradiated (with rapid stirring) with a $450 \mathrm{~W}$ medium pressure Hg Hanovia UV lamp placed inside a water-cooled immersion-well Pyrex filter (Ace Glass, model 7857-05, $\lambda \geq 290 \mathrm{~nm} ; 53 \mathrm{~mm}$ external diameter, $220 \mathrm{~mm}$ full length, $150 \mathrm{~mm}$ depth) for $26 \mathrm{~h}$. The mixture was then poured into sat. aq. $\mathrm{NaCl}(30 \mathrm{~mL})$ and extracted with EtOAc $(3 \times 20 \mathrm{~mL})$. The combined organic layers were dried over $\mathrm{MgSO}_{4}$ and concentrated under reduced pressure to provide disproportionation product $17 \mathbf{f}(2.93 \mathrm{mg}, 13 \%$ yield). (Yield determined by ${ }^{1} \mathrm{H}$ QNMR with dimethyl terephthalate as the external standard).

Note 1: It is important that the crystalline solid be crushed into a fine powder before solvent is added. This can be done with a metal spatula.

Note 2: This reaction proceeds exceptionally slowly. In order to obtain appreciable conversion, it is necessary to maximize substrate surface area. Sonication in SDS (aq) gives $11 \mathrm{f}$ crystals a well-suspended, powdery consistency. 
Note 3: While some of the mass balance is attributed to disproportionation and unidentified decomposition products, a substantial amount of insoluble yellow solid is produced. The identity of this material is unknown.

Note 4: In order to ensure that the crystal polymorph being irradiated was the same as the polymorph observed in the X-ray crystal structure, PXRD data was collected from the crystalline powder prior to irradiation.

Synthesis of Ketones 27, 28, \& 29.

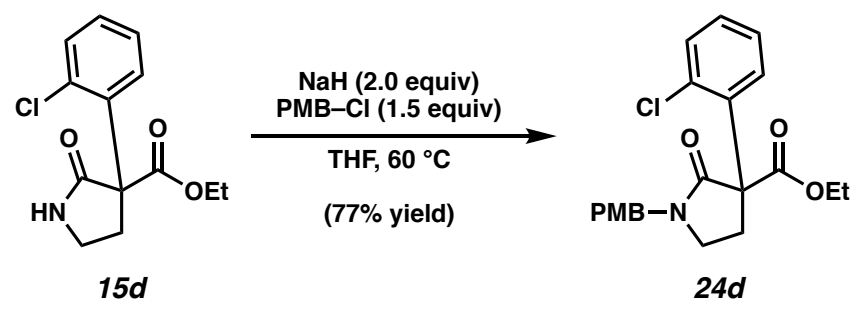

PMB Pyrrolidinone 24d. To a solution of pyrrolidinone 15d (3.01 g, $11.2 \mathrm{mmol}, 1.00$ equiv) in THF (110 mL), was added $\mathrm{NaH}$ (900 mg, $23 \mathrm{mmol}, 2.0$ equiv, 60\% dispersion in mineral oil) with stirring. The reaction was stirred at $23{ }^{\circ} \mathrm{C}$ for $5 \mathrm{~min}$ and 4-methoxybenzyl chloride (2.27 $\mathrm{mL}, 2.63 \mathrm{~g}, 16.8 \mathrm{mmol}, 1.50$ equiv) was added dropwise over $3 \mathrm{~min}$ via syringe. The reaction was placed in a preheated $60^{\circ} \mathrm{C}$ oil bath and stirred for $100 \mathrm{~min}$ before being removed from heat. The reaction was cooled to $0^{\circ} \mathrm{C}$ and quenched by the addition of aq. $\mathrm{HCl}(0.5 \mathrm{M}, 50 \mathrm{~mL})$. The reaction mixture was poured into sat. aq. $\mathrm{NaCl}(200 \mathrm{~mL})$ and the layers were separated. The aqueous layer was extracted with $\mathrm{CH}_{2} \mathrm{Cl}_{2}(2 \times 100 \mathrm{~mL})$ and the combined organic layers were dried over $\mathrm{MgSO}_{4}$ and concentrated under reduced pressure directly onto silica gel (6 g). The crude product was purified by flash column chromatography (12 g silica gel, 9:1 Hexanes:EtOAc $\rightarrow$ 7:3 Hexanes:EtOAc) to provide the protected PMB pyrrolidinone $\mathbf{2 4 d}$ as a viscous oil (3.35 g, 77\% yield). PMB Pyrrolidinone 24d: $\mathrm{R}_{\mathrm{f}} 0.58$ (1:1 Hexanes:EtOAc); ${ }^{1} \mathrm{H}$ NMR $\left(500 \mathrm{MHz}, \mathrm{CDCl}_{3}\right)$ $\delta 7.39-7.35(\mathrm{~m}, 1 \mathrm{H}), 7.35-7.32(\mathrm{~m}, 1 \mathrm{H}), 7.24-7.18(\mathrm{~m}, 4 \mathrm{H}), 6.92-6.82(\mathrm{~m}, 2 \mathrm{H}), 4.58(\mathrm{~d}, J=$ 
$14.5 \mathrm{~Hz}, 1 \mathrm{H}), 4.46(\mathrm{~d}, J=14.5 \mathrm{~Hz}, 1 \mathrm{H}), 4.32-4.16(\mathrm{~m}, 2 \mathrm{H}), 3.79(\mathrm{~s}, 3 \mathrm{H}), 3.40-3.25(\mathrm{~m}, 2 \mathrm{H})$, $3.15-2.99(\mathrm{~m}, 1 \mathrm{H}), 2.23-2.10(\mathrm{~m}, 1 \mathrm{H}), 1.22(\mathrm{t}, J=7.1 \mathrm{~Hz}, 3 \mathrm{H}) ;{ }^{13} \mathrm{C} \mathrm{NMR}\left(125 \mathrm{MHz}, \mathrm{CDCl}_{3}\right)$ $\delta 170.4,170.2,159.4,137.7,133.8,130.6,129.8,128.9,128.8,128.0,127.1,114.3,62.5,62.2$, 55.4, 47.1, 43.9, 31.0, 14.1; HRMS-APCI (m/z) $[\mathrm{M}+\mathrm{H}]^{+}$calcd for $\mathrm{C}_{21} \mathrm{H}_{23} \mathrm{NO}_{4} \mathrm{Cl}^{+}, 388.1310$; found 388.1294 .

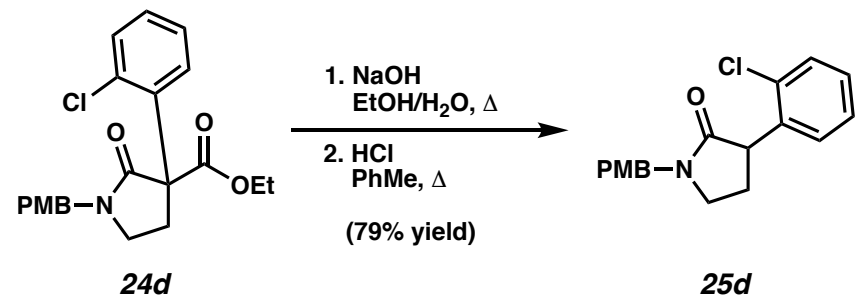

PMB Pyrrolidinone 25d. To a solution of pyrrolidinone 24d (0.46 g, $1.20 \mathrm{mmol}, 1.0$ equiv) in EtOH $(10 \mathrm{~mL})$, was added aq. $\mathrm{NaOH}(1 \mathrm{M}, 15 \mathrm{~mL})$. The reaction was placed in a preheated 100 ${ }^{\circ} \mathrm{C}$ oil bath, stirred at reflux for $20 \mathrm{~min}$, and then cooled to $23{ }^{\circ} \mathrm{C}$. Aq. $\mathrm{HCl}(1.5 \mathrm{~mL}, 12 \mathrm{M})$ was added followed by PhMe $(12 \mathrm{~mL})$. The reaction was placed in a preheated $100{ }^{\circ} \mathrm{C}$ oil bath, stirred at reflux for $3 \mathrm{~h}$, and then cooled to $23{ }^{\circ} \mathrm{C}$. The reaction was diluted with $\mathrm{CH}_{2} \mathrm{Cl}_{2}(100$ $\mathrm{mL})$ and the layers were separated. The aqueous layer was extracted with $\mathrm{CH}_{2} \mathrm{Cl}_{2}(2 \times 50 \mathrm{~mL})$ and the combined organic layers were dried over $\mathrm{MgSO}_{4}$ and then concentrated under reduced pressure directly onto silica gel $(1 \mathrm{~g})$. The crude product was purified by flash column chromatography (5 g silica gel, 9:1 Hexanes:EtOAc $\rightarrow$ 3:2 Hexanes:EtOAc) to provide the PMB pyrrolidinone 25d as a viscous oil (297 mg, 79\% yield). PMB pyrrolidinone 25d: $\mathrm{R}_{\mathrm{f}} 0.59$ (1:1 Hexanes:EtOAc); ${ }^{1} \mathrm{H}$ NMR $\left(500 \mathrm{MHz}, \mathrm{CDCl}_{3}\right) \delta 7.37(\mathrm{dd}, J=7.8,1.4 \mathrm{~Hz}, 1 \mathrm{H}), 7.26-7.17(\mathrm{~m}$, 5H), $6.95-6.84(\mathrm{~m}, 2 \mathrm{H}), 4.58(\mathrm{~d}, J=14.4 \mathrm{~Hz}, 1 \mathrm{H}), 4.43(\mathrm{~d}, J=14.3 \mathrm{~Hz}, 1 \mathrm{H}), 4.15(\mathrm{t}, J=9.2$ $\mathrm{Hz}, 1 \mathrm{H}), 3.82(\mathrm{~s}, 3 \mathrm{H}), 3.41-3.18(\mathrm{~m}, 2 \mathrm{H}), 2.62-2.44(\mathrm{~m}, 1 \mathrm{H}), 1.93(\mathrm{dq}, J=12.9,8.6 \mathrm{~Hz}, 1 \mathrm{H})$; ${ }^{13} \mathrm{C}$ NMR $\left(125 \mathrm{MHz}, \mathrm{CDCl}_{3}\right) \delta 174.0,159.3,138.0,134.4,129.9,129.8,129.6,128.7,128.5$, 
127.4, 114.2, 55.5, 46.7, 46.5, 44.7, 27.3; HRMS-APCI (m/z) $[\mathrm{M}+\mathrm{H}]^{+}$calcd for $\mathrm{C}_{18} \mathrm{H}_{19} \mathrm{NO}_{2} \mathrm{Cl}^{+}$, 316.1099; found 316.1086 .
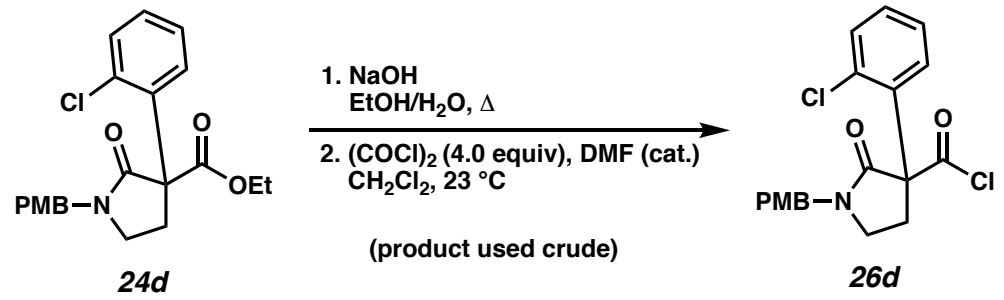

PMB Acid Chloride 26d. To a solution of pyrrolidinone 24d (550 mg, $1.4 \mathrm{mmol}, 1.0$ equiv) in EtOH $(10 \mathrm{~mL})$, was added aq. $\mathrm{NaOH}(1 \mathrm{M}, 15 \mathrm{~mL})$. The reaction was placed in a preheated 100 ${ }^{\circ} \mathrm{C}$ oil bath, stirred at reflux for $10 \mathrm{~min}$, and then cooled to $23{ }^{\circ} \mathrm{C}$. The reaction mixture was poured into aq. $\mathrm{HCl}(1 \mathrm{M}, 30 \mathrm{~mL})$. The layers were separated, the aqueous layer was extracted with $\mathrm{CH}_{2} \mathrm{Cl}_{2}(3 \times 75 \mathrm{~mL})$, and the combined organic layers were dried over $\mathrm{MgSO}_{4}$ and concentrated under reduced pressure. The resultant carboxylic acid was carried forward to the next step.

To neat carboxylic acid from the previous step, was added 1 drop of DMF from a glass Pasteur pipette followed by $\mathrm{CH}_{2} \mathrm{Cl}_{2}(16 \mathrm{~mL})$. Oxalyl chloride $(0.54 \mathrm{~mL}, 790 \mathrm{mg}, 6.2 \mathrm{mmol}, 4.0$ equiv) was added dropwise over $1 \mathrm{~min}$, the reaction was stirred at $23{ }^{\circ} \mathrm{C}$ for $90 \mathrm{~min}$, and then the mixture was concentrated under reduced pressure. The resultant oil was dissolved in $\mathrm{PhMe}(20$ $\mathrm{mL})$ and concentrated under reduced pressure (x2). The crude oil was then put under vacuum $(<$ 1 mbar) for $1 \mathrm{~h}$. Crude acid chloride $\mathbf{2 6 d}$ was used immediately without further purification. 


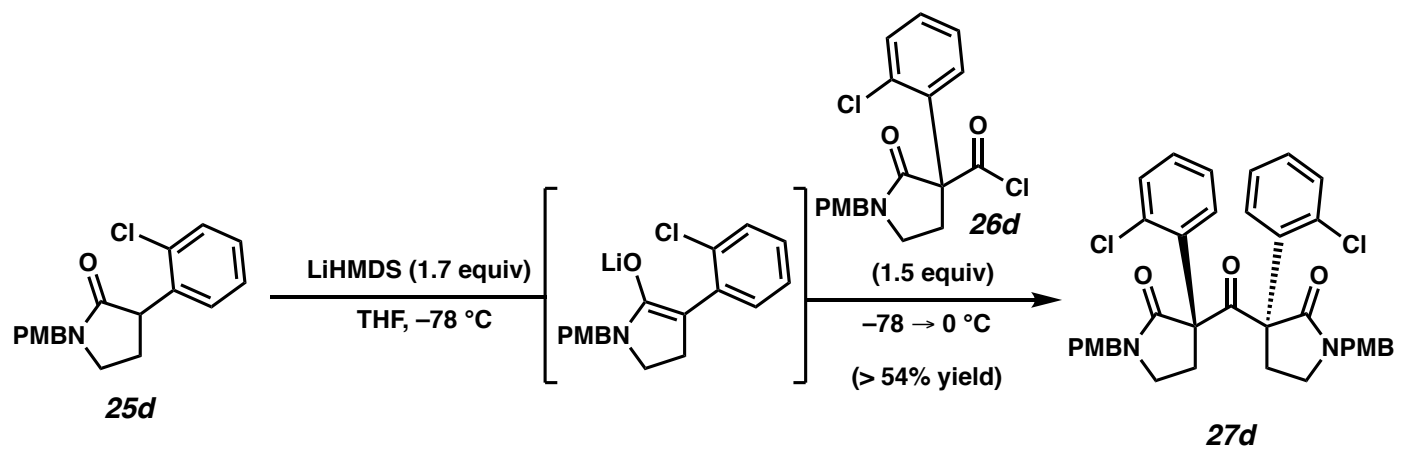

PMB Ketone 27d. To a solution of pyrrolidinone $25 d$ ( $287 \mathrm{mg}, 0.909 \mathrm{mmol}, 1.00$ equiv) in THF $(10 \mathrm{~mL})$ at $-78^{\circ} \mathrm{C}$ was added a solution of LiHMDS (1 M in THF, $1.55 \mathrm{~mL}, 260 \mathrm{mg}, 1.55 \mathrm{mmol}$, 1.70 equiv) dropwise over 1 minute. The reaction was stirred for $30 \mathrm{~min}$ and then a solution of acid chloride 26d (540 mg, $1.4 \mathrm{mmol}, 1.5$ equiv) in THF ( $5 \mathrm{~mL}$ ) was added dropwise over $5 \mathrm{~min}$ and the reaction was immediately removed from the $-78{ }^{\circ} \mathrm{C}$ bath, placed in a $0{ }^{\circ} \mathrm{C}$ bath, and the reaction was stirred for $5 \mathrm{~min}$. The reaction was quenched at $0{ }^{\circ} \mathrm{C}$ by the addition of aq. $\mathrm{HCl}(0.5$ $\mathrm{M}, 5 \mathrm{~mL})$ and poured into a biphasic mixture of $\mathrm{DI} \mathrm{H}_{2} \mathrm{O}(50 \mathrm{~mL})$ and $\mathrm{CH}_{2} \mathrm{Cl}_{2}(75 \mathrm{~mL})$. The layers were separated, and the aqueous layer was extracted with $\mathrm{CH}_{2} \mathrm{Cl}_{2}(2 \times 50 \mathrm{~mL})$. The combined organic layers were dried over $\mathrm{MgSO}_{4}$ and concentrated under reduced pressure directly onto silica gel $(2 \mathrm{~g})$. The crude product was purified by flash column chromatography (20 g silica gel, 4:1 Hexanes:EtOAc) to give ketone PMB ketone 27d (443 mg, 74\% yield) as a white foam. PMB ketone 27d: $\mathrm{R}_{\mathrm{f}} 0.58$ (1:1 Hexanes:EtOAc); ${ }^{1} \mathrm{H}$ NMR $\left(500 \mathrm{MHz}, \mathrm{CDCl}_{3}\right) \delta 7.77$ $(\mathrm{dd}, J=7.1,2.4 \mathrm{~Hz}, 2 \mathrm{H}), 7.53-7.37(\mathrm{~m}, 2 \mathrm{H}), 7.34-7.07(\mathrm{~m}, 8 \mathrm{H}), 6.99-6.72(\mathrm{~m}, 4 \mathrm{H}), 4.98(\mathrm{~d}$, $J=14.6 \mathrm{~Hz}, 2 \mathrm{H}), 4.00(\mathrm{~d}, J=14.6 \mathrm{~Hz}, 2 \mathrm{H}), 3.79(\mathrm{~s}, 6 \mathrm{H}), 3.56(\mathrm{ddd}, J=13.2,8.1,5.1 \mathrm{~Hz}, 2 \mathrm{H})$, $3.26(\mathrm{td}, J=8.7,5.4 \mathrm{~Hz}, 2 \mathrm{H}), 2.99(\mathrm{ddd}, J=9.5,8.0,5.1 \mathrm{~Hz}, 2 \mathrm{H}), 2.32(\mathrm{ddd}, J=13.3,7.9,5.4$ $\mathrm{Hz}, 2 \mathrm{H}) ;{ }^{13} \mathrm{C} \mathrm{NMR}\left(125 \mathrm{MHz}, \mathrm{CDCl}_{3}\right) \delta 197.4,171.1,159.2,137.0,134.0,131.9,130.7,129.9$, 129.1, 128.2, 126.7, 114.2, 69.8, 55.4, 47.6, 44.4, 30.7; HRMS-APCI $(\mathrm{m} / \mathrm{z})[\mathrm{M}+\mathrm{H}]^{+}$calcd for $\mathrm{C}_{37} \mathrm{H}_{35} \mathrm{~N}_{2} \mathrm{O}_{5} \mathrm{Cl}_{2}^{+}, 657.1918$; found 657.1902 . 

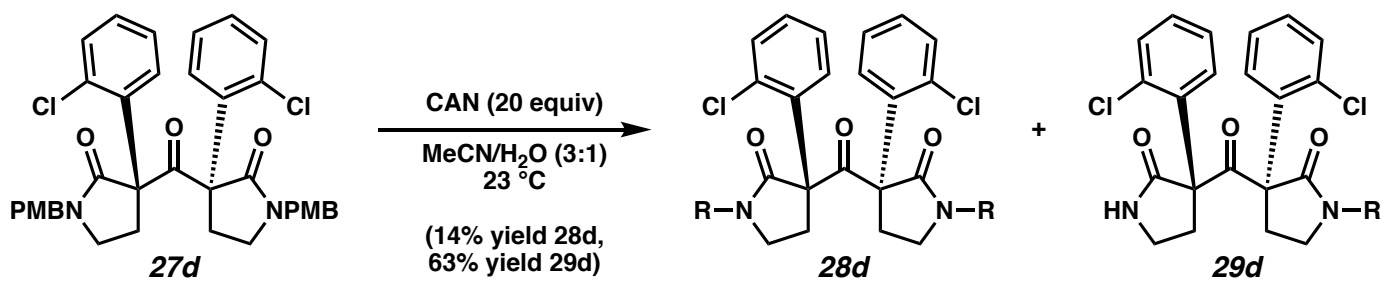

$\mathbf{R}=$ para-Methoxybenzoyl

Ketones 28d \& 29d. Ketone 27d (1.70 g, 2.59 mmol, 1.00 equiv) was dissolved in MeCN (275 $\mathrm{mL})$. Once solid was completely dissolved, $\mathrm{DI} \mathrm{H}_{2} \mathrm{O}(90 \mathrm{~mL})$ was added. To this stirring mixture was added CAN (28.1 g, $51.3 \mathrm{mmol}, 20.0$ equiv) in a single portion and the reaction was allowed to stir at $23{ }^{\circ} \mathrm{C}$ for $105 \mathrm{~min}$ before being poured into a biphasic mixture of $\mathrm{H}_{2} \mathrm{O}(800 \mathrm{~mL})$ and $\mathrm{CH}_{2} \mathrm{Cl}_{2}(400 \mathrm{~mL})$. The layers were separated and the aqueous layer was washed with $\mathrm{CH}_{2} \mathrm{Cl}_{2}(2$ x $300 \mathrm{~mL}$ ). The combined organic layers were dried over $\mathrm{MgSO}_{4}$ and concentrated directly onto silica gel ( $4 \mathrm{~g})$. The crude product was then purified by flash column chromatography ( $20 \mathrm{~g}$ silica gel, 4:1 Hexanes:EtOAc $\rightarrow$ 3:1 Hexanes:EtOAc) to furnish ketone $\mathbf{2 8 d}$ (241 $\mathrm{mg}, 14 \%$ yield) and ketone 29d (1.11g, 63\% yield). Crystals of both 28d (reactive polymorph, CCDC 2006465) and 29d (CCDC 2006466) suitable for X-ray diffraction studies were obtained as follows: pure ketone $(30 \mathrm{mg})$ was dissolved in minimal $\mathrm{CHCl}_{3}(\sim 2 \mathrm{~mL}) n$ Hexane $(\sim 6 \mathrm{~mL})$ was layered on top of $\mathrm{CHCl}_{3}$ solution and the layers were allowed to slowly diffuse together over 3 days. Crystal of 28d (unreactive polymorph, CCDC 2006467) was grown via slow evaporation from $\mathrm{CH}_{2} \mathrm{Cl}_{2}$.

Ketone 28d: $\mathrm{R}_{\mathrm{f}} 0.58\left(1: 1\right.$ Hexanes:EtOAc); ${ }^{1} \mathrm{H} \mathrm{NMR}\left(500 \mathrm{MHz}, \mathrm{CDCl}_{3}\right) \delta 7.67-7.59(\mathrm{~m}, 6 \mathrm{H})$, $7.48(\mathrm{dd}, J=7.7,1.7 \mathrm{~Hz}, 2 \mathrm{H}), 7.32(\mathrm{td}, J=7.5,1.8 \mathrm{~Hz}, 2 \mathrm{H}), 7.28(\mathrm{td}, J=7.6,1.7 \mathrm{~Hz}, 2 \mathrm{H}), 6.86-$ $6.76(\mathrm{~m}, 4 \mathrm{H}), 3.94-3.83(\mathrm{~m}, 2 \mathrm{H}), 3.76(\mathrm{~s}, 6 \mathrm{H}), 3.54(\mathrm{dt}, J=13.3,7.0 \mathrm{~Hz}, 2 \mathrm{H}), 3.45(\mathrm{dt}, J=$ $10.8,6.8 \mathrm{~Hz}, 2 \mathrm{H}), 2.55(\mathrm{ddd}, J=12.7,7.0,5.5 \mathrm{~Hz}, 2 \mathrm{H}) ;{ }^{13} \mathrm{C}$ NMR $\left(125 \mathrm{MHz}, \mathrm{CDCl}_{3}\right) \delta 194.7$, $172.5,169.4,163.0,134.7,133.8,132.4,131.9,130.4,129.9,127.2,126.0,113.4,71.2,55.4$, 45.3, 30.0; HRMS-APCI (m/z) $[\mathrm{M}+\mathrm{H}]^{+}$calcd for $\mathrm{C}_{37} \mathrm{H}_{31} \mathrm{~N}_{2} \mathrm{O}_{7} \mathrm{Cl}_{2}{ }^{+}, 685.1503$; found 685.1516. 
Ketone 29d: $\mathrm{R}_{\mathrm{f}} 0.51\left(1: 1\right.$ Hexanes:EtOAc); ${ }^{1} \mathrm{H}$ NMR $\left(500 \mathrm{MHz}, \mathrm{CDCl}_{3}\right) \delta 7.92-7.79(\mathrm{~m}, 3 \mathrm{H})$, $7.52-7.39(\mathrm{~m}, 3 \mathrm{H}), 7.32-7.26(\mathrm{~m}, 3 \mathrm{H}), 7.22(\mathrm{td}, J=7.6,1.5 \mathrm{~Hz}, 1 \mathrm{H}), 6.99-6.92(\mathrm{~m}, 2 \mathrm{H})$, $5.56(\mathrm{~s}, 1 \mathrm{H}), 3.95-3.82(\mathrm{~m}, 4 \mathrm{H}), 3.59-3.43(\mathrm{~m}, 3 \mathrm{H}), 3.26(\mathrm{tdd}, J=8.0,4.9,1.6 \mathrm{~Hz}, 1 \mathrm{H}), 3.05$ (ddd, $J=9.4,7.4,5.8 \mathrm{~Hz}, 1 \mathrm{H}), 2.64-2.49(\mathrm{~m}, 2 \mathrm{H}) ;{ }^{13} \mathrm{C} \mathrm{NMR}\left(125 \mathrm{MHz}, \mathrm{CDCl}_{3}\right) \delta$ 195.7, 174.5, $172.0,169.8,162.7,135.2,135.1,134.2,133.4,132.1,131.9,131.9,130.7,130.5,129.5,129.4$, $127.0,126.9,126.7,113.0,71.6,67.7,55.4,44.5,39.5,33.1,29.5 ;$ HRMS-APCI $(\mathrm{m} / \mathrm{z})[\mathrm{M}+\mathrm{H}]^{+}$ calcd for $\mathrm{C}_{29} \mathrm{H}_{25} \mathrm{~N}_{2} \mathrm{O}_{5} \mathrm{Cl}_{2}{ }^{+}, 551.1135$; found 551.1141.

Note 1: The workup in this reaction makes a very challenging emulsion. This was partially mitigated by simply collecting all three organic layers (from three washes) as somewhat of an emulsion and only discarding the layer that was mostly aqueous and did not contain substantial organic emulsion. To this emulsion was added copious $\mathrm{MgSO}_{4}$. This caused emulsion to dissipate. The organic layer here was collected.

Note 2: It is absolutely critical for the subsequent solid-state photochemistry that this solid is completely pure. It is recommended that, after chromatography, this be recrystallized. This can be done either from 1:1 Hexanes:EtOAc or via layer diffusion (Bottom layer $=\mathrm{CH}_{2} \mathrm{Cl}_{2}$, top layer $=n$-Hexane) .

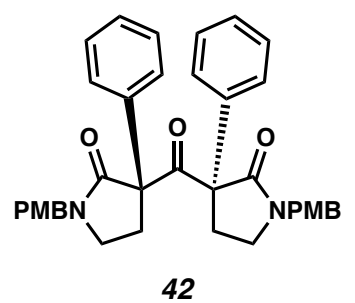

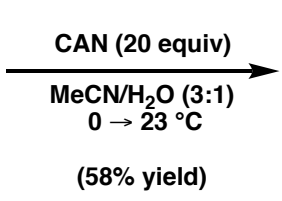

(58\% yield)

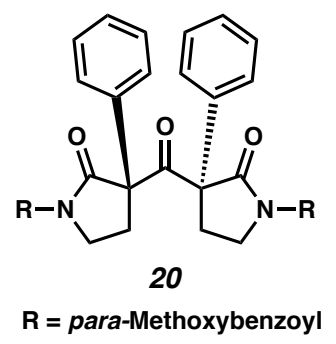

Ketone 20. A solution of ketone $\mathbf{4 2}^{27}$ (90 mg, $0.15 \mathrm{mmol}, 1.0$ equiv) was dissolved in MeCN (15 $\mathrm{mL})$ and $\mathrm{DI} \mathrm{H}_{2} \mathrm{O}(5 \mathrm{~mL})$ and cooled to $0{ }^{\circ} \mathrm{C}$. CAN $(1.7 \mathrm{~g}, 3.0 \mathrm{mmol}, 20$ equiv) was added and the reaction was stirred for 90 min before being allowed to warm to $23{ }^{\circ} \mathrm{C}$. After being stirred at 23 ${ }^{\circ} \mathrm{C}$ for $30 \mathrm{~min}$, the reaction was poured into a mixture of $\mathrm{H}_{2} \mathrm{O}(100 \mathrm{~mL})$ and $\mathrm{CH}_{2} \mathrm{Cl}_{2}(100 \mathrm{~mL})$. 
The layers were separated and the organic layer was washed with $\mathrm{CH}_{2} \mathrm{Cl}_{2}(2 \times 100 \mathrm{~mL})$. The combined organic layers were dried over $\mathrm{MgSO}_{4}$ and concentrated directly onto silica gel. The crude product was then purified by flash column chromatography (9:1 Hexanes:EtOAc $\rightarrow$ 7:3 Hexanes:EtOAc) to furnish ketone 20 (55 mg, 58\% yield). Crystals suitable for X-ray diffraction analysis were grown via slow evaporation from $\mathrm{CDCl}_{3} / \mathrm{n}-\mathrm{Hexane}$ (CCDC 2006460), EtOAc/nHexane (CCDC 2006464), and EtOH (CCDC 2006468). Ketone 20: $\mathrm{R}_{\mathrm{f}} 0.55 \quad(1: 1$ Hexanes:EtOAc); ${ }^{1} \mathrm{H}$ NMR (500 MHz, $\left.\mathrm{CDCl}_{3}\right) \delta 7.68-7.63(\mathrm{~m}, 4 \mathrm{H}), 7.35-7.29$ (m, 6H), 7.19 $-7.12(\mathrm{~m}, 4 \mathrm{H}), 6.92-6.85(\mathrm{~m}, 4 \mathrm{H}), 3.94-3.78(\mathrm{~m}, 8 \mathrm{H}), 3.55(\mathrm{ddd}, J=10.7,8.5,6.8 \mathrm{~Hz}, 2 \mathrm{H})$, $3.15(\mathrm{dt}, J=13.2,8.1 \mathrm{~Hz}, 2 \mathrm{H}), 2.20(\mathrm{ddd}, J=13.1,6.5,3.6 \mathrm{~Hz}, 2 \mathrm{H}) ;{ }^{13} \mathrm{C}$ NMR $(125 \mathrm{MHz}$, $\left.\mathrm{CDCl}_{3}\right) \delta 200.1,171.9,169.7,163.3,134.9,132.0,129.2,128.5,127.4,125.9,113.4,69.3,55.6$ 44.1, 30.8; HRMS-APCI (m/z) $[\mathrm{M}+\mathrm{H}]^{+}$calcd for $\mathrm{C}_{37} \mathrm{H}_{33} \mathrm{~N}_{2} \mathrm{O}_{7}^{+}, 617.2282$; found 617.2268.

\subsubsection{Photodecarbonylation of Ketones $28 d$ and 29d.}
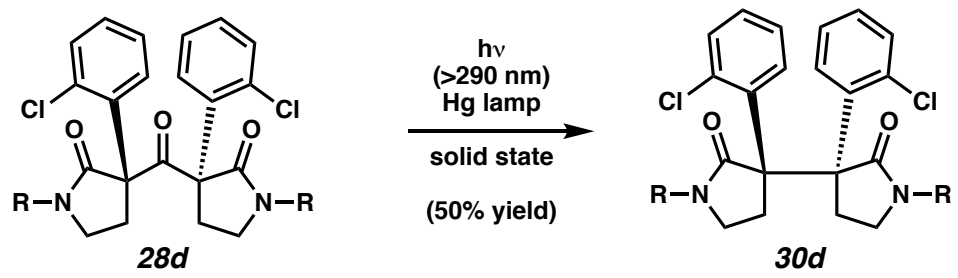

$\mathbf{R}=$ para-Methoxybenzoyl

Bis(pyrrolidinone) 30d. Ketone 28d (96 mg) was suspended in $\mathrm{Et}_{2} \mathrm{O}(\sim 15 \mathrm{~mL})$ and sonicated for 1 min. During sonication, clear suspension rapidly turned white/cloudy. This was allowed to evaporate under ambient conditions until visible $\mathrm{Et}_{2} \mathrm{O}$ was gone at which point the resultant white solid was placed under high vacuum $(<1 \mathrm{mbar})$ for $2 \mathrm{~h}$. A small portion of $\mathbf{2 8 d}(18.6 \mathrm{mg}$, $27.1 \mu \mathrm{mol}, 1.00$ equiv) was suspended in THF (1.0 mL) (Note 1) and added to a vortexing solution of aq. SDS $(0.7 \mathrm{mg} / \mathrm{mL}, 7 \mathrm{~mL})$ (Note 2$)$. The reaction was transferred to a 4-dram vial 
with rapid stirring, giving a suspension of ketone $\mathbf{2 8 d}$. This suspension was irradiated with a 450 W medium pressure Hg Hanovia UV lamp placed inside a water-cooled immersion-well Pyrex filter (Ace Glass, model 7857-05, $\lambda \geq 290 \mathrm{~nm} ; 53 \mathrm{~mm}$ external diameter, $220 \mathrm{~mm}$ full length, 150 $\mathrm{mm}$ depth) for $21 \mathrm{~h}$. The reaction was poured into a biphasic mixture of sat. aq. $\mathrm{NaCl}(20 \mathrm{~mL})$ and EtOAc $(20 \mathrm{~mL})$. The layers were separated, and the aqueous layer was extracted with EtOAc $(2 \times 20 \mathrm{~mL})$. The combined organic layers were dried over $\mathrm{MgSO}_{4}$ before being concentrated under reduced pressure directly onto silica gel $(200 \mathrm{mg})$. The crude product was purified by flash column chromatography ( 2 g silica gel, 9:1 Hexanes:EtOAc $\rightarrow$ 7:3 Hexanes:EtOAc) to give the bis(pyrrolidinone) 30d as a white solid $(9.01 \mathrm{mg}, 50 \%$ yield). Crystals suitable for X-ray diffraction studies (CCDC 2006469) were prepared by evaporation for toluene- $d_{8}$ (Note 3). Bis(pyrrolidinone) 30d: $\mathrm{R}_{\mathrm{f}} 0.56\left(1: 1\right.$ Hexanes:EtOAc); ${ }^{1} \mathrm{H}$ NMR $\left(600 \mathrm{MHz}\right.$, Toluene- $\left.d_{8}\right) \delta 7.83-$ $7.74(\mathrm{~m}, 4 \mathrm{H}), 7.31(\mathrm{~s}, 2 \mathrm{H}), 7.14(\mathrm{dd}, J=7.9,1.5 \mathrm{~Hz}, 2 \mathrm{H}), 6.78(\mathrm{td}, J=7.6,1.5 \mathrm{~Hz}, 2 \mathrm{H}), 6.76-$ $6.71(\mathrm{~m}, 6 \mathrm{H}), 3.97-3.75(\mathrm{~m}, 4 \mathrm{H}), 3.42(\mathrm{dt}, J=13.7,8.1 \mathrm{~Hz}, 2 \mathrm{H}), 3.32(\mathrm{~s}, 6 \mathrm{H}), 2.82(\mathrm{~s}, 2 \mathrm{H}) ;{ }^{13} \mathrm{C}$ NMR (151 MHz, Toluene- $\left.d_{8}\right) \delta$ 175.0, 169.8, 163.5, 135.6, 134.4, 133.3, 132.5, 132.2, 128.4, 126.0, 113.7, 62.0, 55.1, 44.2, 28.9; HRMS-APCI $(\mathrm{m} / \mathrm{z})[\mathrm{M}+\mathrm{H}]^{+}$calcd for $\mathrm{C}_{37} \mathrm{H}_{31} \mathrm{~N}_{2} \mathrm{O}_{6} \mathrm{Cl}_{2}{ }^{+}$, 657.1554; found 657.1538 .

Note 1: Solid 28d did not fully dissolve in THF prior to being added into the aq. solution of SDS and was instead a milky-white suspension.

Note 2: Vortexing SDS solution: A $25 \mathrm{~mL}$ culture tube containing $7 \mathrm{~mL} S D S$ solution $(0.7 \mathrm{mg} / \mathrm{mL}$ in $\mathrm{DI} \mathrm{H}_{2} \mathrm{O}$ ) was placed on a Thermo-Fischer Maxi-Mix ${ }^{\circledR} 0.5 \mathrm{~W}, 60 \mathrm{~Hz}$ vortex mixer. Once the aq. solution was rapidly vortexing, the solution of ketone in SDS was added dropwise from a syringe. 
Note 3: After collecting NMR spectra at $100{ }^{\circ} \mathrm{C}$ a small amount of in toluene-d $d_{8}$ evaporated and resulted in the growth of high-quality crystals (on the walls of the NMR tube) which were submitted directly for X-ray diffraction analysis.

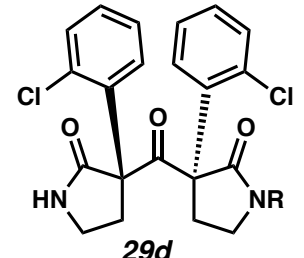

$\mathbf{R}=$ para-Methoxybenzoyl

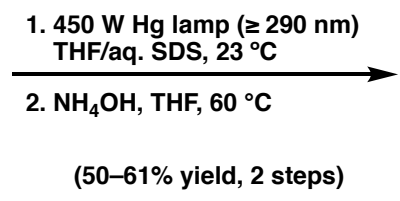

(50-61\% yield, 2 steps)

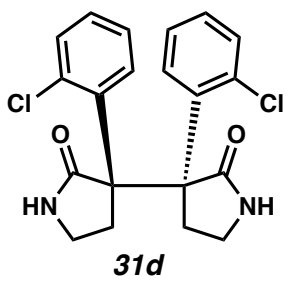

31d

Bis(pyrrolidinone) 31d. A solution of ketone $29 d$ (77.1 mg, $0.140 \mathrm{mmol}, 1.00$ equiv) dissolved in THF $(6 \mathrm{~mL})$ was added dropwise into a vortexing aqueous solution of sodium dodecyl sulfate $(0.7 \mathrm{mg} / \mathrm{mL}, 40 \mathrm{~mL})$ (see Note 1 for vortexing procedure). The resultant suspension was irradiated with a $450 \mathrm{~W}$ medium pressure Hg Hanovia UV lamp placed inside a water-cooled immersion-well Pyrex filter (Ace Glass, model 7857-05, $\lambda \geq 290 \mathrm{~nm} ; 53 \mathrm{~mm}$ external diameter, $220 \mathrm{~mm}$ full length, $150 \mathrm{~mm}$ depth) for $49 \mathrm{~h}$ (see Note 3 for reaction monitoring). The reaction was poured into a biphasic mixture of sat. aq. $\mathrm{NaCl}(50 \mathrm{~mL})$ and EtOAc $(50 \mathrm{~mL})$. The layers were separated and the aqueous layer was extracted with EtOAc $(3 \times 25 \mathrm{~mL})$. The combined organic layers were dried over $\mathrm{Na}_{2} \mathrm{SO}_{4}$ before being concentrated under reduced pressure. Residual SDS was removed by flushing the crude oil over a short silica plug $(5 \mathrm{~cm})$ with EtOAc $(50 \mathrm{~mL})$ and the resultant solution was concentrated under reduced pressure and used without further purification.

To a solution of the crude photoproduct in THF $(20 \mathrm{~mL})$ in a heavy-walled tube, $\mathrm{NH}_{4} \mathrm{OH}$ $(30-32 \% \mathrm{w} / \mathrm{v}, 1.0 \mathrm{~mL})$ was added. The vessel was sealed with a Teflon screwcap, submerged in an oil bath preheated to $65{ }^{\circ} \mathrm{C}$ and stirred for $90 \mathrm{~min}$. The reaction was allowed to cool to $23{ }^{\circ} \mathrm{C}$ and was diluted with $\mathrm{CH}_{2} \mathrm{Cl}_{2}(30 \mathrm{~mL}) . \mathrm{H}_{2} \mathrm{O}(50 \mathrm{~mL})$ was added and the layers were separated. The aqueous layer was extracted with $\mathrm{CH}_{2} \mathrm{Cl}_{2}(3 \times 30 \mathrm{~mL})$ and the combined organic layers were 
dried over $\mathrm{Na}_{2} \mathrm{SO}_{4}$ and then concentrated under reduced pressure directly onto silica gel $(0.5 \mathrm{~g})$. The crude product was purified by flash column chromatography (4 g silica gel, 1:1 Hexanes:EtOAc $\rightarrow 100 \%$ EtOAc) to give the bis(pyrrolidinone) 31d as a glassy solid (29.4 mg, 54\% yield). Yields ranged from 50-61\%. Bis(pyrrolidinone) 31d: $\mathrm{R}_{\mathrm{f}} 0.42$ (EtOAc); ${ }^{1} \mathrm{H}$ NMR $\left(600 \mathrm{MHz}, \mathrm{CDCl}_{3}\right) \delta 8.48(\mathrm{~s}, 2 \mathrm{H}), 7.47(\mathrm{dd}, J=8.0,1.3 \mathrm{~Hz}, 2 \mathrm{H}), 7.34-7.26(\mathrm{~m}, 2 \mathrm{H}), 7.19(\mathrm{t}, J=$ $7.5 \mathrm{~Hz}, 2 \mathrm{H}), 7.03(\mathrm{t}, J=7.4 \mathrm{~Hz}, 2 \mathrm{H}), 3.56(\mathrm{td}, J=9.9,3.2 \mathrm{~Hz}, 2 \mathrm{H}), 3.43(\mathrm{ddd}, J=13.5,9.9,3.4$ $\mathrm{Hz}, 2 \mathrm{H}), 3.35(\mathrm{td}, J=9.2,4.4 \mathrm{~Hz}, 2 \mathrm{H}), 2.75(\mathrm{ddd}, J=14.2,10.4,4.4 \mathrm{~Hz}, 2 \mathrm{H}) ;{ }^{13} \mathrm{C} \mathrm{NMR}(125$ $\left.\mathrm{MHz}, \mathrm{CDCl}_{3}\right) \delta 178.4,139.5,135.0,134.7,132.4,128.5,125.0,59.8,41.1,33.5 ;$ HRMS-APCI $(\mathrm{m} / \mathrm{z})[\mathrm{M}+\mathrm{H}]^{+}$calcd for $\mathrm{C}_{20} \mathrm{H}_{19} \mathrm{Cl}_{2} \mathrm{~N}_{2} \mathrm{O}_{2}{ }^{+}, 389.0818$; found, 389.0810.

Note 1: Vortexing SDS solution: A $100 \mathrm{~mL}$ graduated cylinder containing $40 \mathrm{~mL}$ SDS solution (0.7 mg/mL in $\mathrm{DI} \mathrm{H} \mathrm{H}_{2} \mathrm{O}$ ) was placed on a Thermo-Fischer Maxi-Mix ${ }^{\circledR} 0.5 \mathrm{~W}, 60 \mathrm{~Hz}$ vortex mixer. Once the aq. solution was rapidly vortexing, the solution of ketone in SDS was added dropwise from a syringe (see image below).

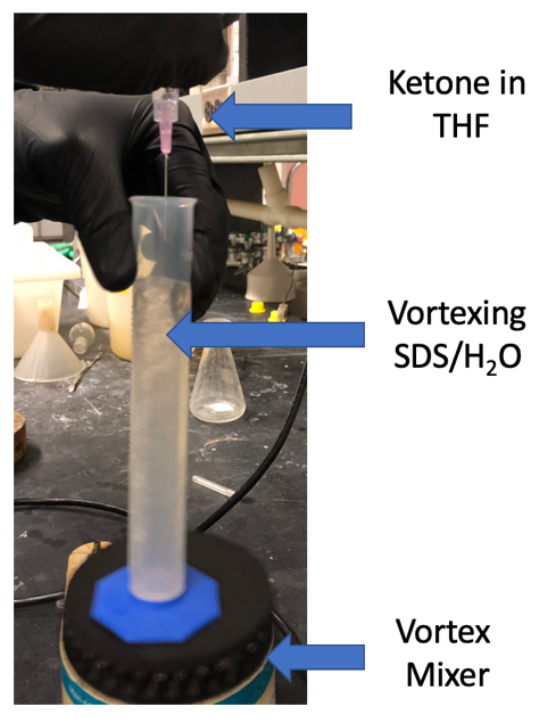


Note 2: During the reaction, the solids have a tendency to become clumped on the side of the glass. This aggregation limits surface area and slows reaction progress. To mitigate this problem, the reaction is stopped every $\sim 4-8 \mathrm{~h}$ and the aggregated solid broken up by swirling the solution rapidly with a glass pipette.

Note 3: It is critical to monitor this reaction by aliquots using ${ }^{1} H$ NMR analysis as reaction times can vary based on how much solid adheres to the glass. Aliquots are collected as follows: $0.5 \mathrm{~mL}$ of the suspension was removed from the reaction mixture and poured into a culture tube with sat.

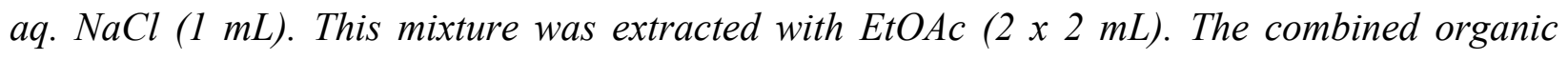
layers were dried over $\mathrm{Na}_{2} \mathrm{SO}_{4}$ and then flushed through a plug of silica gel $(\sim 3 \mathrm{~cm})$ with EtOAc $(10 \mathrm{~mL})$. It is important to flush through silica gel prior to collection of NMR spectrum as it removes residual SDS. If this is not done, the ${ }^{1} H$ NMR resonances become very broad as a result of the SDS and it is difficult to ascertain reaction conversion.

Note 4: It is critical to maintain rapid stirring so that the solids remain suspended throughout the course of the reaction.

Note 5: The 450W Hg lamp produces significant heat. This is mitigated by the jacket of cooling water and fans to circulate warm air out of the box containing the irradiation setup.

Note 6: Bis(pyrrolidinone) 30d is difficult to visualize by TLC analysis. Very concentrated solutions may be visualized on TLC with a $254 \mathrm{~nm}$ handheld UV-lamp. 


\section{Computational Section}

The reaction mechanism was studied using density functional theory (DFT). All quantum mechanics calculations were performed with Gaussian 09. Atomic coordinates were extracted from the X-ray diffraction data. The $\mathrm{ONIOM}^{4,5}$ approach within the hybrid QM/MM method ${ }^{6}$ was employed to account for the intermolecular interactions within the crystal lattice environment. The central layer was a single molecule described at unrestricted closed-shell dispersion-corrected B97X-D/6-311G(d,p) level. The surrounding shell of molecules extracted from the experimentally determined crystal structure was used as the low layer with electronically embedded UFF. We favor the employment of a molecular mechanics method to describe the low-level layer (over semiempirical methods or quantum chemical calculations with very small basis sets) since the MM force field by definition includes a description of dispersion effects between all atoms in the MM region and between $\mathrm{QM}$ and $\mathrm{MM}$ regions. Indeed, this hybrid approach has been shown to be accurate in computational studies of solid-state transformations of stilbene where crystalline environment calculations were included in the lowlevel layer. Vibrational frequencies were computed at the QM/MM level to determine if the optimized structures are minima or saddle points on the potential energy surface corresponding to minima and transition state geometries, respectively. Transition structures have been verified by intrinsic reaction coordinate (IRC) calculations. The partitioning of atoms into the two layers is shown in Figure $\mathbf{S 1}$ using a "ball-and-stick" representation for the atoms treated by the DFT method and a "wire" representation for the atoms in the low-level layer.

Some initial energy minimization calculations were done on the isolated molecules in the gas phase. We mimicked Norrish Type I photodecarbonylation by removing carbonyl moiety and allowing the two radical fragments to relax to their ground state (GS) geometries. In all instances 
geometry optimization led to radical recombination for all studied ortho- and meta-substituted systems. The success of GS optimization for radical fragments was critically dependent on embedding them in their respective crystal cavities. Our computational model entailed the two radical fragments surrounded by the shell of ketones, as determined by X-ray diffraction studies. Carbon monoxide moiety was excluded from the computational model. Performing energy minimization yielded a GS structure with the two fragments positioned at the $\sim 2.7 \AA$ distance. A relaxed scan for bond association between the two fragments was performed to map out the potential energy profile for recombination and predict the transition state (TS) structure. Frequency calculations for the TS structures yielded one imaginary frequency corresponding to the in-plane asymmetric stretching of the two radical fragments. In all instances, the radicals were $\sim 2.5 \AA$ distance apart. The calculated electronic barriers supported the experimental trend and were in the range of $\sim 2-5 \mathrm{kcal} / \mathrm{mol}$ for systems that show high selectivity and $6-7 \mathrm{kcal} / \mathrm{mol}$ for systems that show low recombination selectivity. We hypothesize that the origin of the chemoselectivity is directly related to the conformation adopted by the reactants in the crystal cavity and the intramolecular steric hindrance, which creates a $2-7 \mathrm{kcal} / \mathrm{mol}$ barrier for radical recombination. 


\section{Computed Solid-State Disproportion Barriers for Radical Pair 10 (Figure S1).}

In order to gain further insight into the chemoselectivity of the solid-state photodecarbonylation reaction, we investigated the conversion of radical pair $\mathbf{1 0}$ to the disproportionation products 17 and 19 (Figure S1) by modeling the transition state of the reactions. The transition state structures $\mathbf{4 3}$, obtained from these calculations, appeared qualitatively reasonable based on our assumptions about the disproportionation event. The shorter bond lengths of the breaking $\mathrm{C}-\mathrm{H}$ bonds $(1.21-1.22 \AA)$ relative to the forming $\mathrm{C}-\mathrm{H}$ bonds (1.58-1.61 $\AA$ ), depicted in blue and red respectively, are consistent with the early transition states expected. ${ }^{7}$ Furthermore, the $\mathrm{C}-\mathrm{H}-\mathrm{C}$ angle of the hydrogen transfer ranges from $165.8^{\circ}$ to $178.7^{\circ}$ (not shown). While this is compressed relative to an ideal $180^{\circ}$ geometry, it is not surprising given the conformational restrictions imposed by the crystalline cavity. The calculated energetic barriers to disproportionation for 43a, 43d, and 43e are dramatically higher than initially expected. This suggests, contrary to the experimental observations, that disproportionation would be too unfavorable to compete with $\mathrm{C}-\mathrm{C}$ bond formation (calculated barriers ranged from 1.7 to $6.8 \mathrm{kcal} / \mathrm{mol}$ for the latter reaction). Given the apparent discrepancy between the computed transition state energies of 43a, 43d, and 43e and our empirical findings (see Figure 4), we hypothesize that disproportionation in these substrates could be occurring via a quantum tunneling mechanism. Hydrogen atom tunneling has been well-documented in solid state reactions and seems reasonable in this instance, given the short distance that the hydrogen

atom must travel to accomplish the transformation. ${ }^{8-15}$ We aim to experimentally probe the potential role of hydrogen atom tunneling in solid-state disproportionation events in future studies. 
Dotson et al.: Discovery and Total Synthesis of Psychotriadine-Supporting Information - S40 
Figure S1.
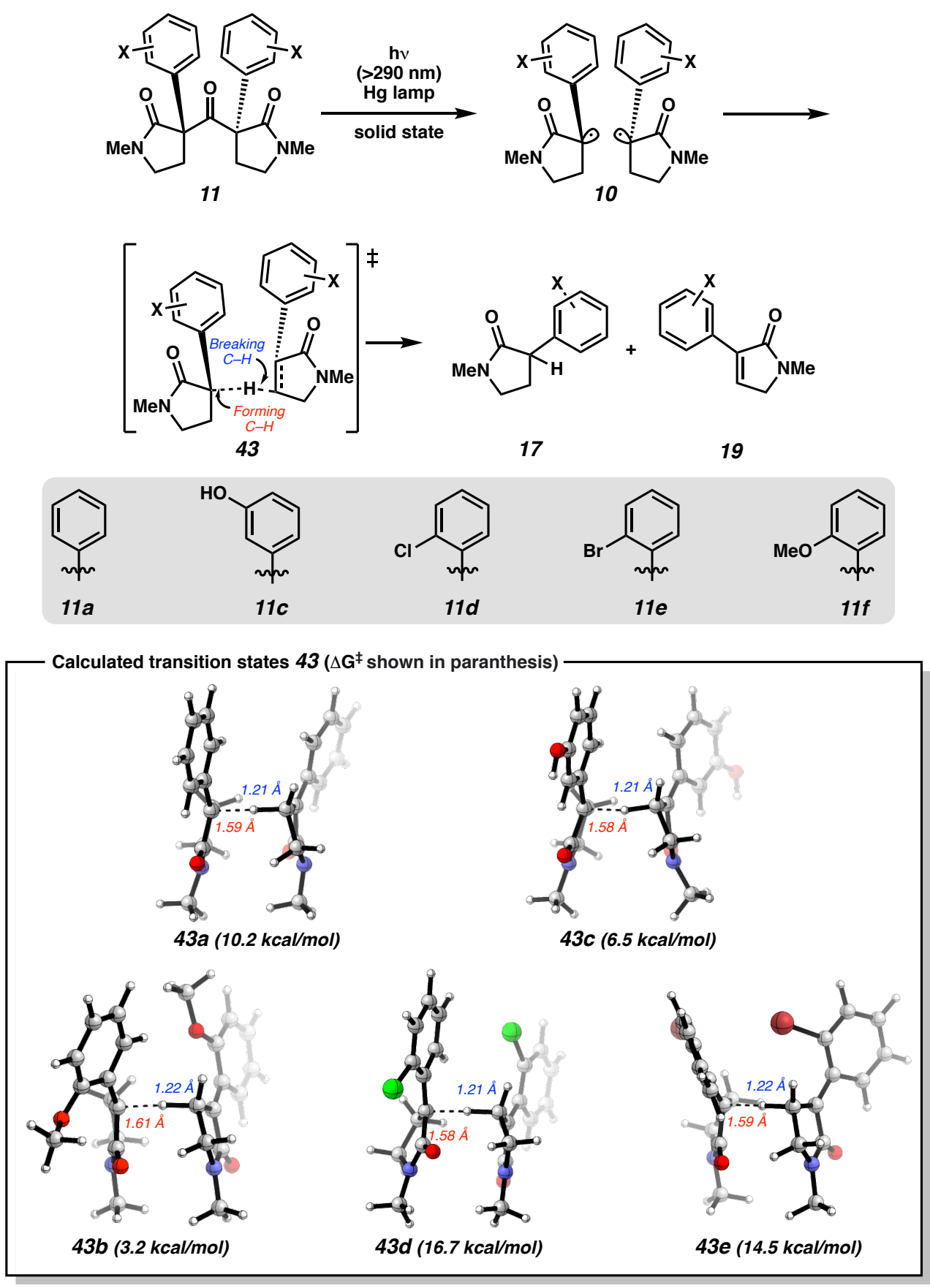


\section{Powder X-ray Diffraction Data}

Simulated and experimental PXRD patterns of ketone 11a before solid-state irradiation.
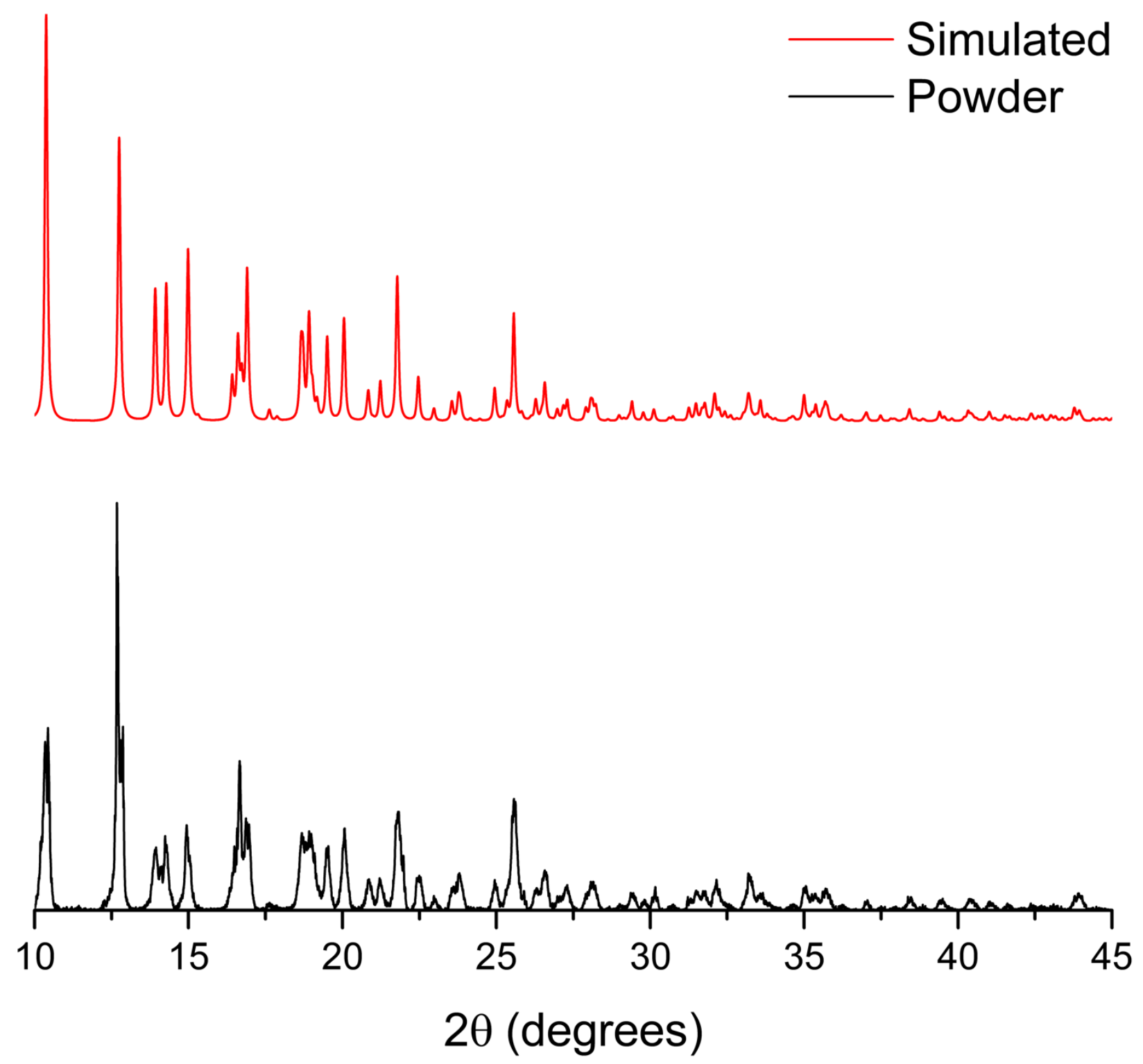
Simulated and experimental PXRD patterns of ketone 11c before solid-state irradiation.
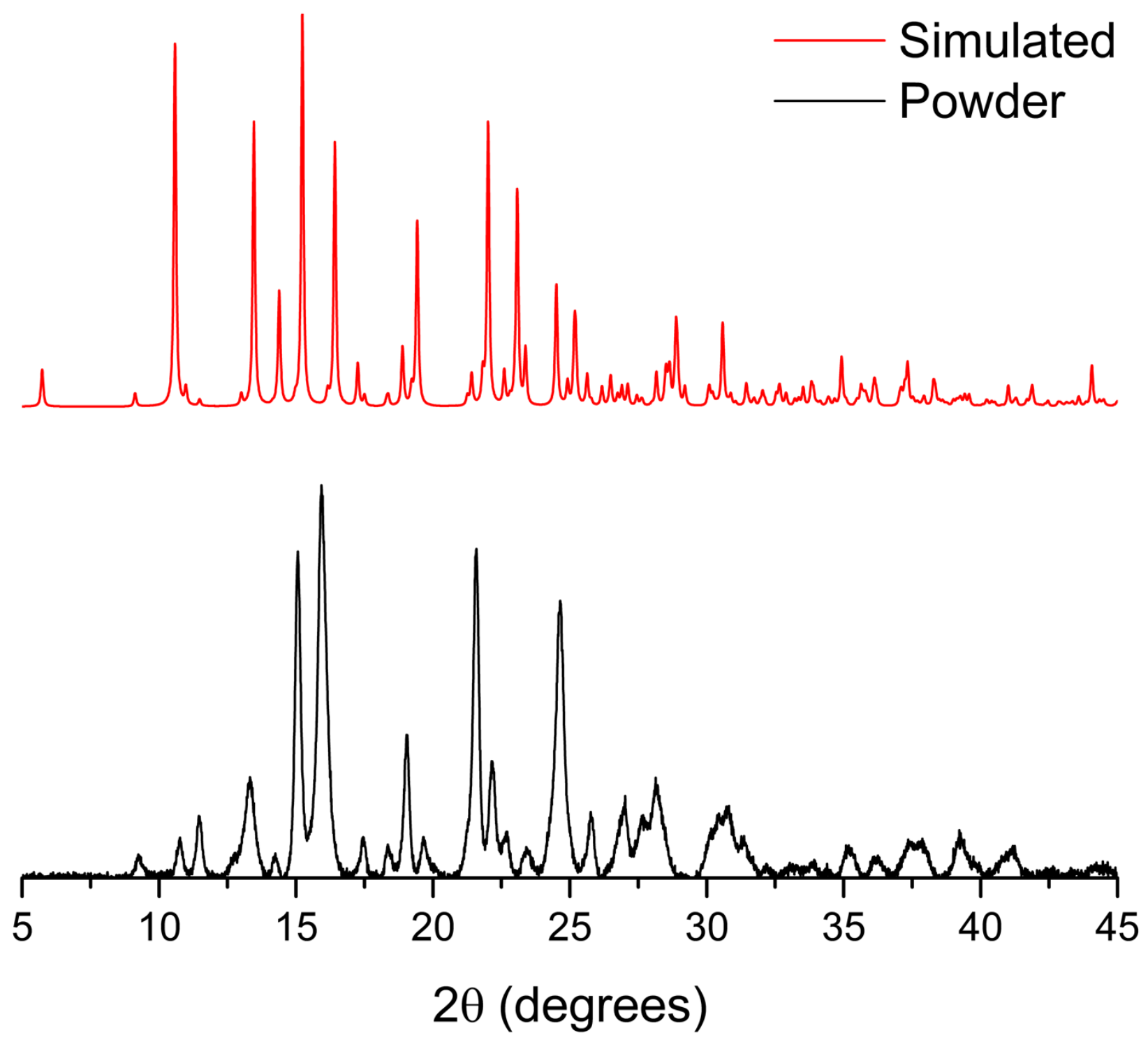
Simulated and experimental PXRD patterns of ketone 11d before solid-state irradiation.
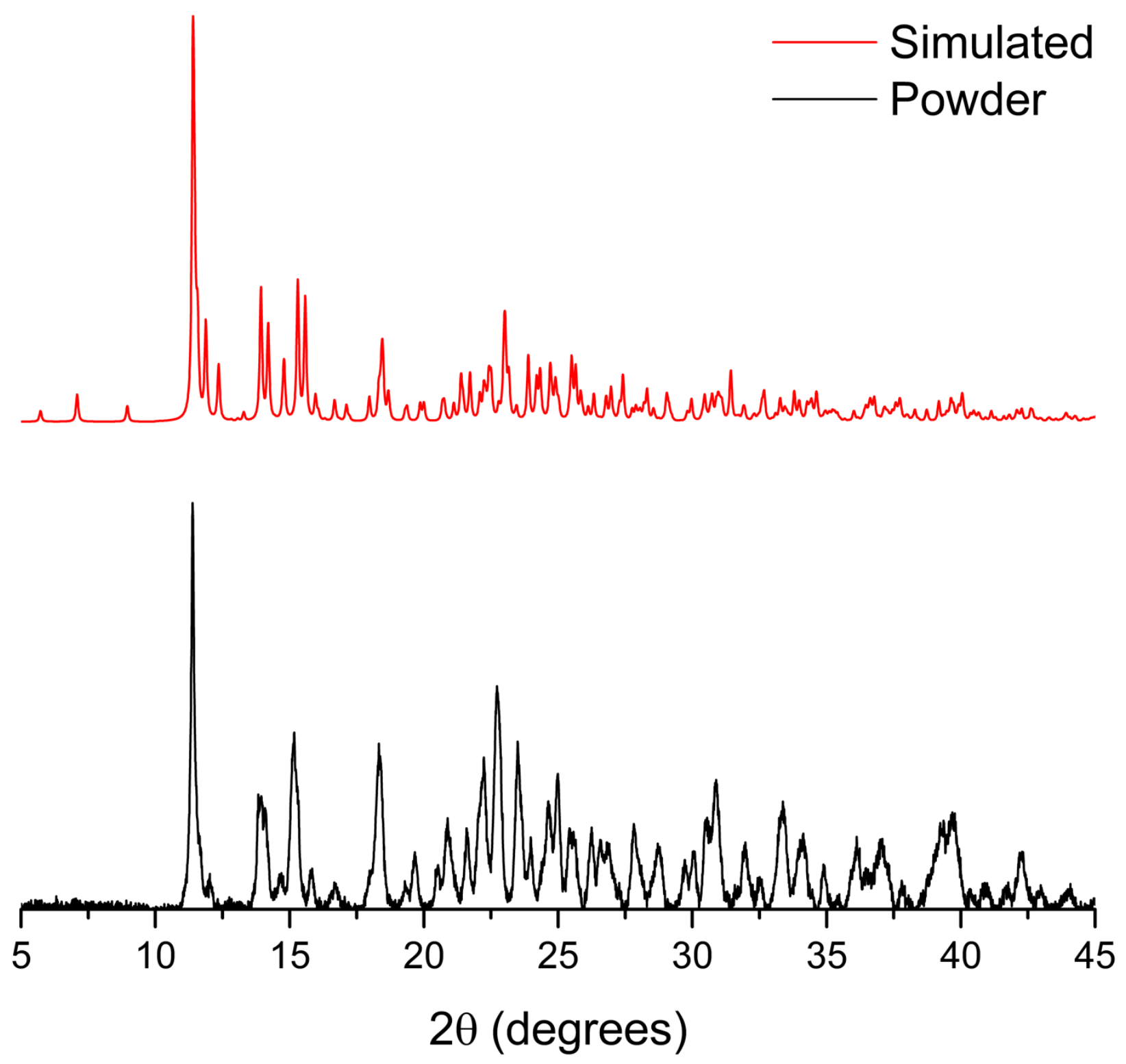
Simulated and experimental PXRD patterns of ketone $11 \mathbf{f}$ before solid-state irradiation.
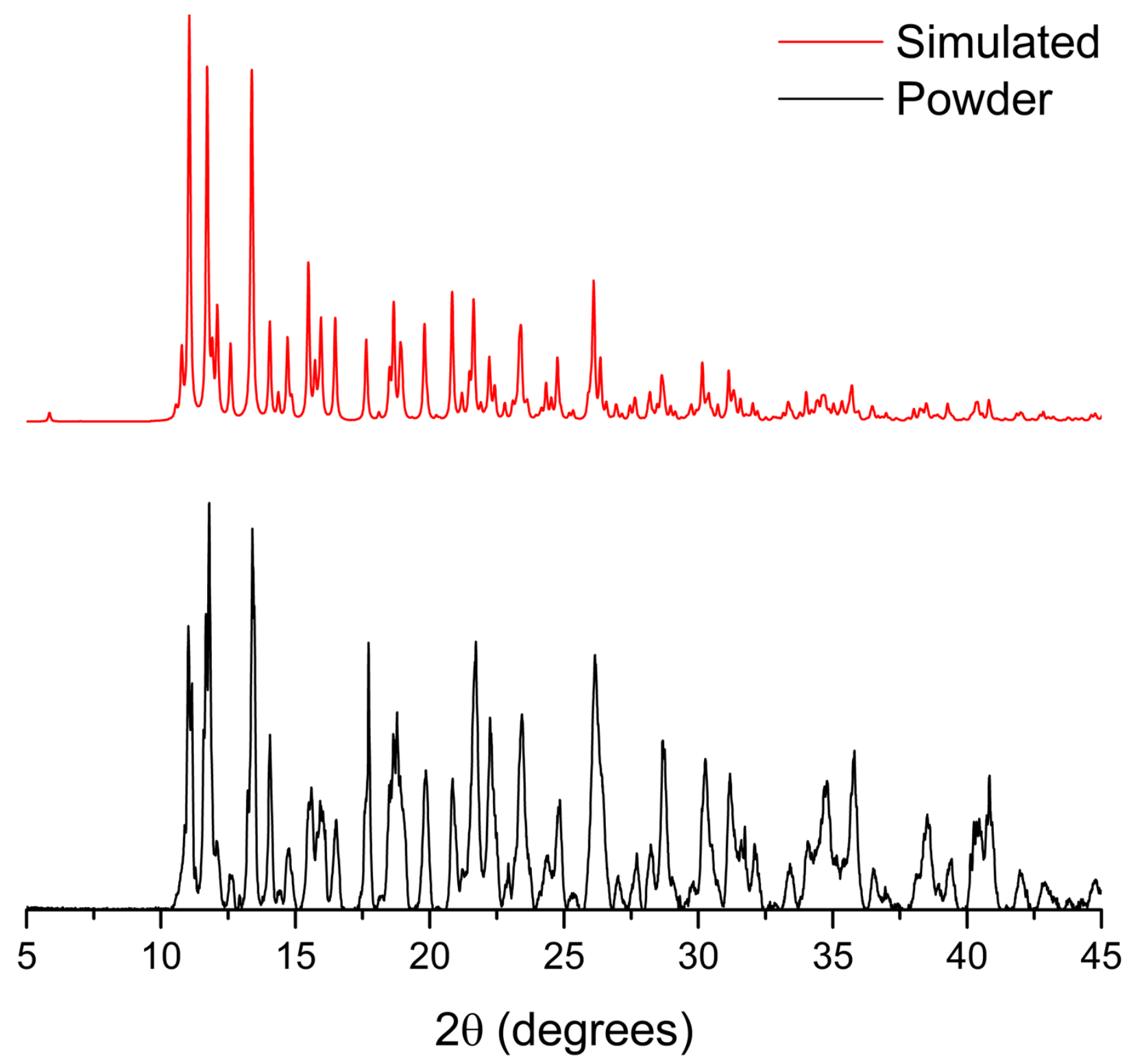


\section{MicroED Methods}

Single crystal structures of $\mathbf{2 9 d}$ and $\mathbf{2 9}$ e were obtained using both microcrystal electron diffraction (microED) as well as single-crystal X-ray diffraction and the resultant are depicted in Figure S1. The microED method was originally developed and deployed for crystallographic analysis of proteins, and has since seen extensive use in this area. ${ }^{16,17}$ More recently, it has been shown that microED can also elucidate small molecule crystal structures. ${ }^{\mathrm{b}}$ TEM grids were submerged in finely ground powders of 29d and 29e, then used for microED data collection on an FEI Tecnai TF-30 electron microscope. Structures obtained by X-ray diffraction and microED are in very close agreement (Figure S2). Despite the lower resolution and poorer R-factors of the microED structures, these results demonstrate the potential of this method for future use in optimization of solid-state photochemical reactions. Since microED can be performed without growing macroscopic crystals, which often involves screening many crystallization conditions and significant wait times for crystal growth, it may enable greater efficiency in the determination of the best candidate substrates based on the desired crystalline conformation. 
Figure S2. Comparison between structures derived for 29d and 29e using both single-crystal Xray diffraction and microED.
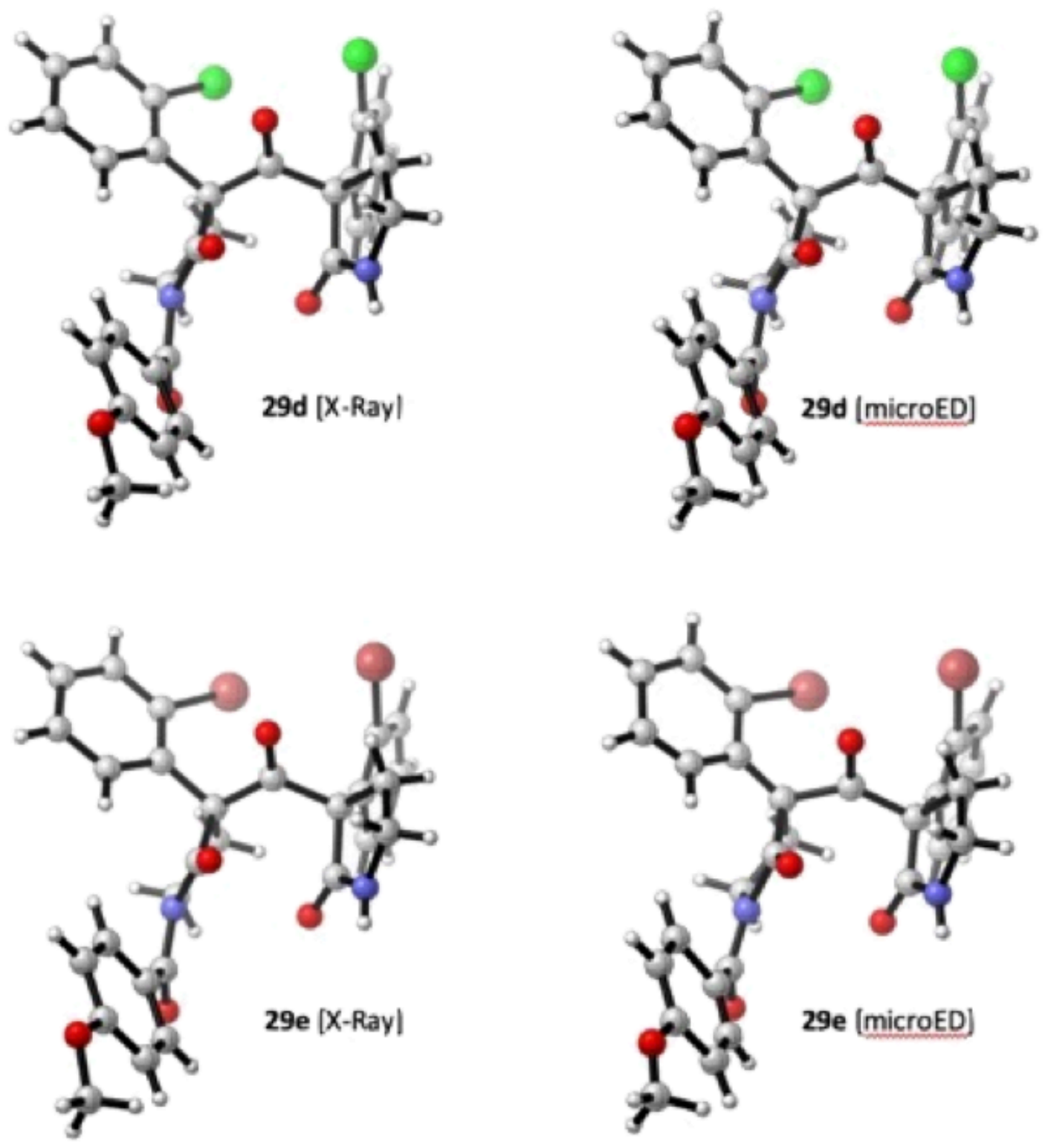


\section{Crystal Structure Data}

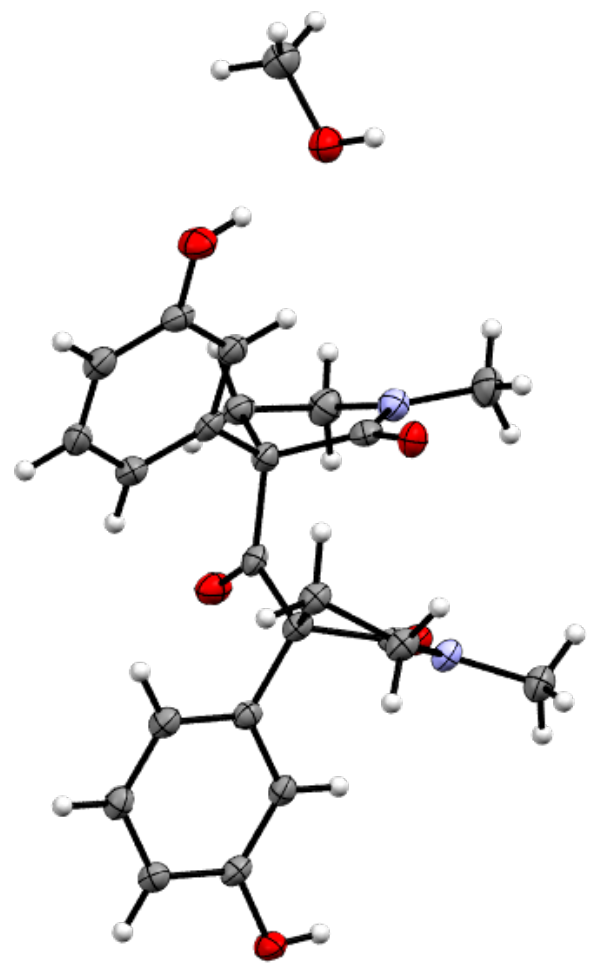

Crystal data and structure refinement for 11c.

Bond precision: $\mathrm{C}-\mathrm{C}=0.0030$ A Wavelength $=1.54178$

Cell: $a=15.4150(11) b=7.2655(6) c=19.3811(13)$

alpha $=90$ beta $=92.331(5)$ gamma $=90$

Temperature: $100 \mathrm{~K}$

Volume 2168.8(3)

Space group P 21/c

Hall group -P 2ybc

Moiety formula C24 H28 N2 O6

Sum formula C24 H28 N2 O6

$\operatorname{Mr} 440.48$

Dx,g cm-3 1.349 
Z 44

$\mathrm{Mu}(\mathrm{mm}-1) 0.802$

F000 936.0

F000' 939.03

$\mathrm{h}, \mathrm{k}, \operatorname{lmax} 18,8,23$

Nref 4037

Tmin,Tmax $0.490,0.750$

Tmin' 0.908

Correction method $=\#$ Reported T Limits: Tmin $=0.490$

Tmax $=0.750$ AbsCorr $=$ MULTI-SCAN

Data completeness $=0.968$ Theta $(\max )=70.952$

$\mathrm{R}($ reflections $)=0.0557(2779) \mathrm{wR} 2($ reflections $)=0.1587(4037)$

$\mathrm{S}=1.005 \mathrm{Npar}=295$ 


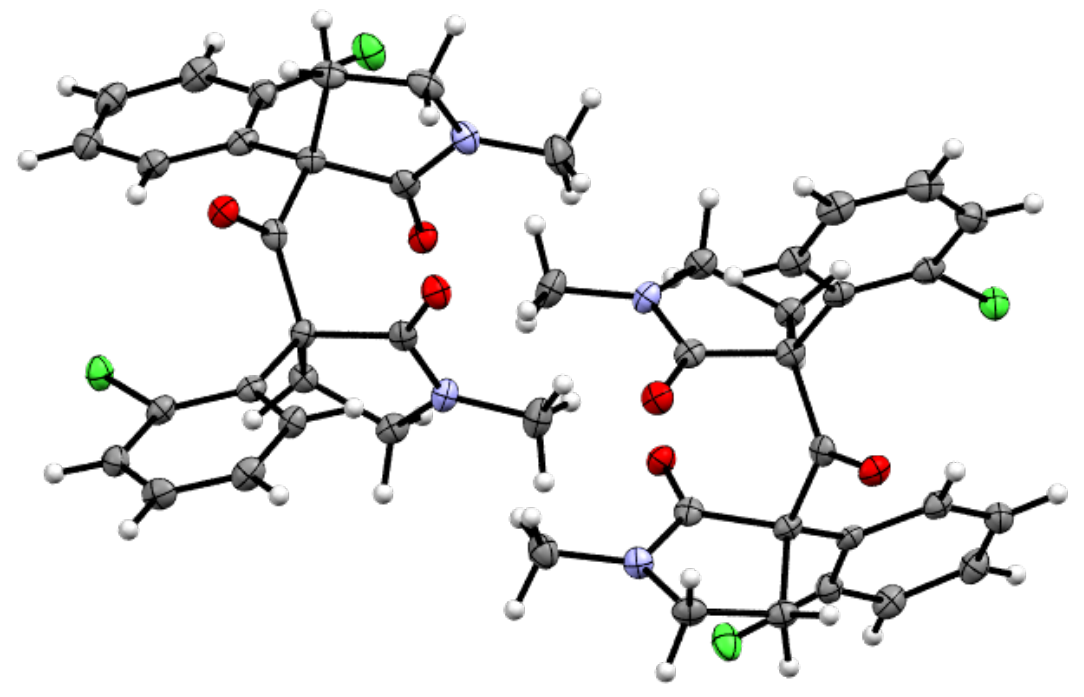

Crystal data and structure refinement for $\mathbf{1 1 d}$.

Bond precision: $\mathrm{C}-\mathrm{C}=0.0027$ A Wavelength $=1.54178$

Cell: $a=8.3651(2) b=15.8542(3) c=16.0938(3)$

alpha $=103.010(1)$ beta $=98.028(1)$ gamma $=90.894(1)$

Temperature: $100 \mathrm{~K}$

Calculated Reported

Volume 2056.77(7)

Space group P -1

Hall group -P 1

Moiety formula C23 H22 Cl2 N2 O3

Sum formula C23 H22 Cl2 N2 O3

$\operatorname{Mr} 445.32$

Dx,g cm-3 1.438

Z 44

$\mathrm{Mu}(\mathrm{mm}-1) 3.077$

F000 928.0 
F000' 933.32

h,k, $\operatorname{lmax} 10,19,19$

Nref 7361

Tmin, Tmax $0.650,0.750$

Tmin' 0.515

Correction method $=\#$ Reported T Limits: $T$ min $=0.650$

$\operatorname{Tmax}=0.750$ AbsCorr $=$ MULTI-SCAN

Data completeness $=0.952$ Theta $(\max )=69.484$

$\mathrm{R}($ reflections $)=0.0320(5947) \mathrm{wR} 2($ reflections $)=0.0869(7361)$

$\mathrm{S}=1.110 \mathrm{Npar}=545$ 


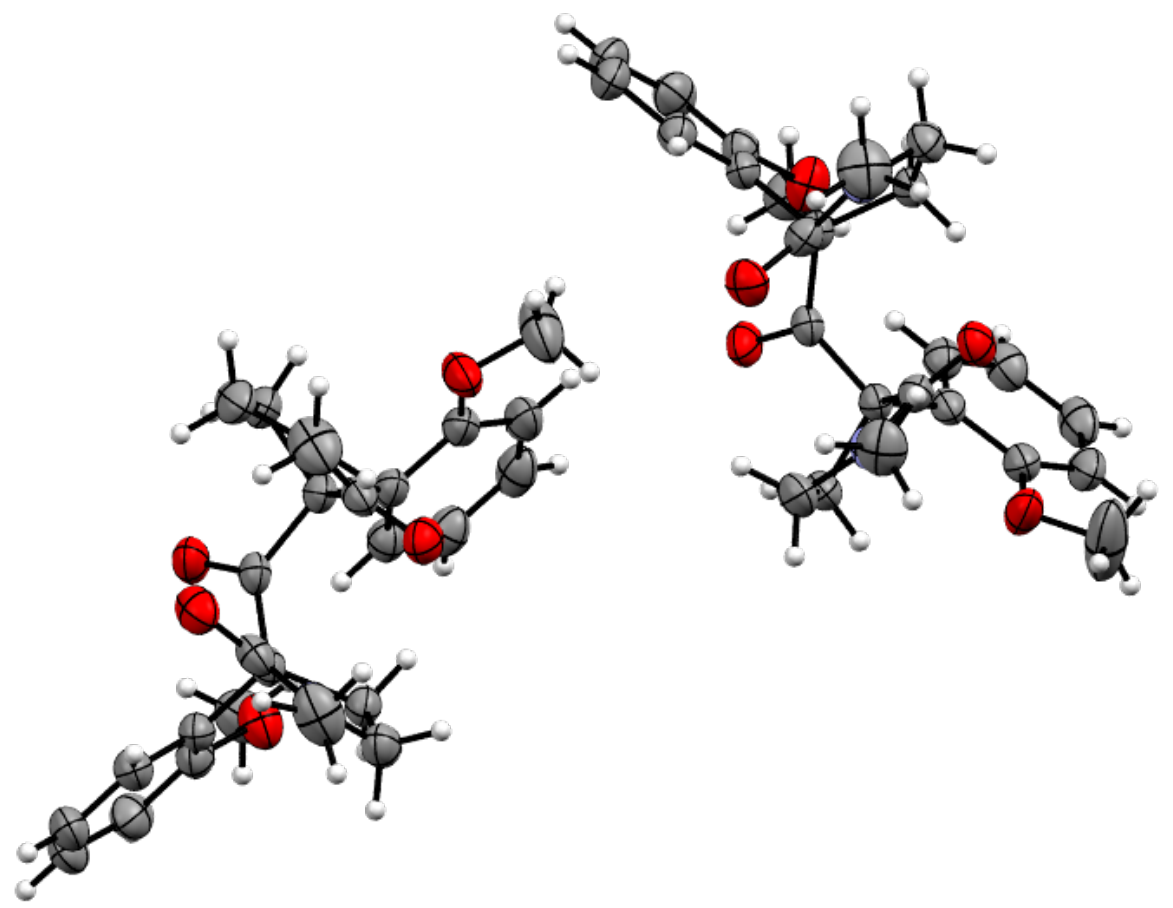

Crystal data and structure refinement for $\mathbf{1 1 f}$.

Bond precision: $\mathrm{C}-\mathrm{C}=0.0022 \mathrm{~A}$ Wavelength $=1.54178$

Cell: $\mathrm{a}=8.5466(7) \mathrm{b}=15.7765(12) \mathrm{c}=16.8359(12)$

alpha $=102.568(4)$ beta $=90.391(4)$ gamma $=101.143(5)$

Temperature: $295 \mathrm{~K}$

Calculated Reported

Volume 2171.1(3)

Space group P -1

Hall group -P 1

Moiety formula C25 H28 N2 O5

Sum formula C25 H28 N2 O5

Mr 436.49

Dx,g cm-3 1.335 
Z 4

$\mathrm{Mu}(\mathrm{mm}-1) 0.761$

F000 928.0

F000' 930.90

h,k,lmax 10,19,20

Nref 8166

Tmin,Tmax 0.913,0.941

Tmin' 0.796

Correction method $=$ \# Reported T Limits: $\mathrm{Tmin}=0.630$

$\operatorname{Tmax}=0.750$ AbsCorr $=$ MULTI-SCAN

Data completeness $=0.953 \operatorname{Theta}(\max )=69.477$

$\mathrm{R}($ reflections $)=0.0423(6362) \mathrm{wR} 2($ reflections $)=0.1275(7786)$

$\mathrm{S}=1.051 \mathrm{Npar}=585$ 


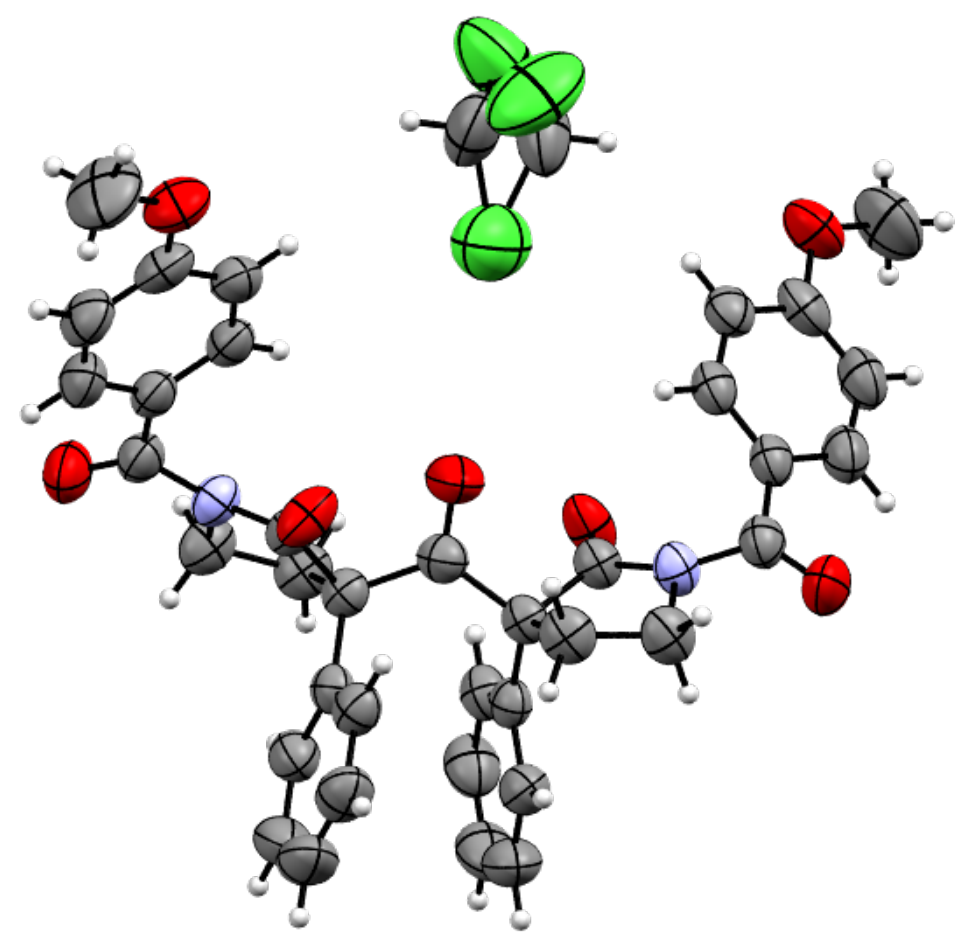

Crystal data and structure refinement for $\mathbf{2 0}\left(\mathrm{CDCl}_{3}\right.$ co-crystal $)$.

Bond precision: $\mathrm{C}-\mathrm{C}=0.0039$ A Wavelength $=1.54178$

Cell: $a=19.6360(14) b=15.2276(11) c=13.0169(10)$

alpha $=90$ beta $=112.999(4)$ gamma $=90$

Temperature: $293 \mathrm{~K}$

Calculated Reported

Volume 3582.8(5)

Space group C $2 / \mathrm{c}$

Hall group -C 2yc

Moiety formula C37 H32 N2 O7, C H Cl3

Sum formula C38 H33 Cl3 N2 O7

Mr 736.01

Dx,g cm-3 1.364 
Z 4

$\mathrm{Mu}(\mathrm{mm}-1) 2.750$

F000 1528.0

F000' 1536.60

$\mathrm{h}, \mathrm{k}, \operatorname{lmax} 23,18,15$

Nref 3306

Tmin,Tmax $0.530,0.750$

Tmin' 0.333

Correction method $=\#$ Reported T Limits: Tmin $=0.530$

$\operatorname{Tmax}=0.750$ AbsCorr $=$ MULTI-SCAN

Data completeness $=0.970$ Theta $(\max )=70.091$

$\mathrm{R}($ reflections $)=0.0601(2289) \mathrm{wR} 2($ reflections $)=0.1932(3306)$

$\mathrm{S}=1.106 \mathrm{Npar}=234$ 


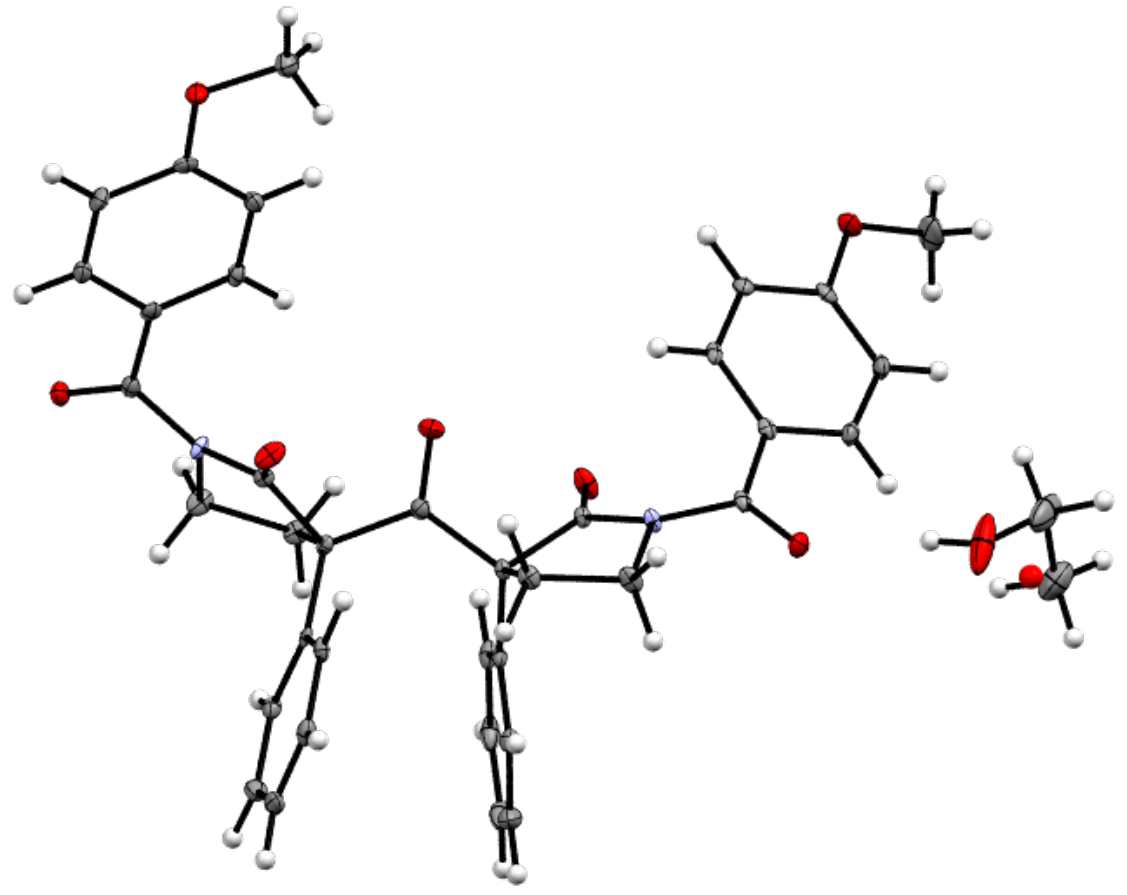

Crystal data and structure refinement for $\mathbf{2 0}$ (EtOH co-crystal).

Bond precision: $\mathrm{C}-\mathrm{C}=0.0030$ A Wavelength $=1.54178$

Cell: $\mathrm{a}=18.3925(3) \mathrm{b}=14.5726(3) \mathrm{c}=12.6603(2)$

alpha $=90$ beta $=103.375(1)$ gamma $=90$

Temperature: $100 \mathrm{~K}$

Calculated Reported

Volume 3301.26(10)

Space group P 21/c

Hall group -P 2ybc

Moiety formula

C37 H32 N2 O7, 0.926(C2 H6 O),

$0.074(\mathrm{O})$

Sum formula C38.85 H37.56 N2 O8

Mr 660.49 
Dx,g cm-3 1.333

Z 4

$\mathrm{Mu}(\mathrm{mm}-1) 0.764$

F000 1394.7

F000' 1399.12

$\mathrm{h}, \mathrm{k}, \operatorname{lmax} 22,17,15$

Nref 6182

Tmin,Tmax $0.500,0.750$

Tmin' 0.682

Correction method $=\#$ Reported T Limits: Tmin $=0.500$

Tmax $=0.750$ AbsCorr $=$ MULTI-SCAN

Data completeness $=0.995 \operatorname{Theta}(\max )=69.531$

$\mathrm{R}($ reflections $)=0.0567(4940)$ 


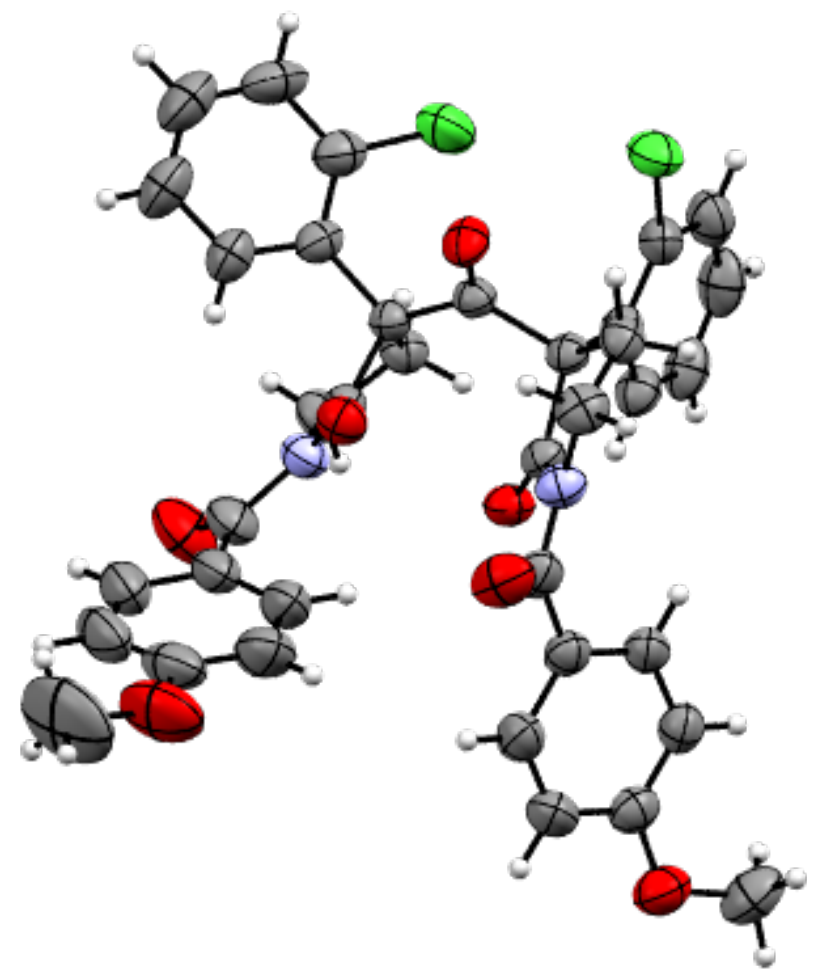

Crystal data and structure refinement for $\mathbf{2 8 d}$ (reactive polymorph).

Bond precision: $\mathrm{C}-\mathrm{C}=0.0042$ A Wavelength $=1.54178$

Cell: $a=28.2314(3) b=28.2314(3) c=21.6709(3)$

alpha $=90$ beta $=90$ gamma $=120$

Temperature: $298 \mathrm{~K}$

Calculated Reported

Volume 14958.0(4) 14958.0(4)

Space group R -3 R -3 :H

Hall group -R 3 -R 3

Moiety formula C37 H30 Cl2 N2 O7

Sum formula C37 H30 C12 N2 O7

Mr 685.53

Dx,g cm-3 1.370 
Z 18

$\mathrm{Mu}(\mathrm{mm}-1) 2.202$

F000 6408.0

F000' 6439.76

h,k,lmax 32,34,26

Nref 6266

Tmin, Tmax $0.650,0.750$

Tmin' 0.613

Correction method $=$ \# Reported T Limits: Tmin $=0.650$

$\operatorname{Tmax}=0.750$ AbsCorr $=$ MULTI-SCAN

Data completeness $=0.991$ Theta $(\max )=69.994$

$\mathrm{R}($ reflections $)=0.0472(4690) \mathrm{wR} 2($ reflections $)=0.1502(6266)$

$\mathrm{S}=1.046 \mathrm{Npar}=435$ 


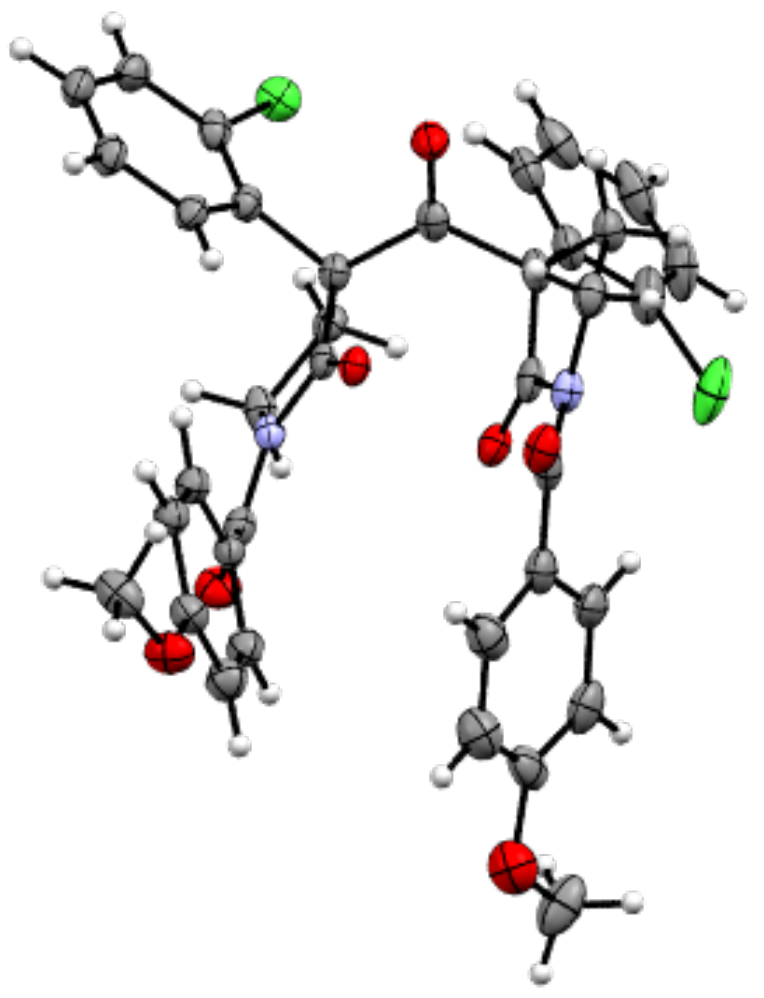

Crystal data and structure refinement for $\mathbf{2 8 d}$ (unreactive polymorph).

Bond precision: $\mathrm{C}-\mathrm{C}=0.0061 \mathrm{~A}$ Wavelength $=1.54178$

Cell: $a=13.1482(6) b=14.7869(7) c=16.3314(7)$

alpha $=90$ beta $=90.461(2)$ gamma $=90$

Temperature: $100 \mathrm{~K}$

Calculated Reported

Volume 3175.1(2) 3175.1(2)

Space group P 21/c P 21/c

Hall group -P 2ybc -P 2ybc

Moiety formula C37 H30 Cl2 N2 O7

Sum formula C37 H30 C12 N2 O7

$\operatorname{Mr} 685.53$ 
Dx,g cm-3 1.434

Z 4

$\mathrm{Mu}(\mathrm{mm}-1) 2.305$

F000 1424.0

F000' 1431.06

$\mathrm{h}, \mathrm{k}, \operatorname{lmax} 15,17,19$

Nref 5992

Tmin,Tmax 0.610,0.740

Tmin' 0.794

Correction method $=\#$ Reported T Limits: Tmin $=0.610$

Tmax $=0.740$ AbsCorr $=$ MULTI-SCAN

Data completeness $=0.987 \operatorname{Theta}(\max )=70.542$

$\mathrm{R}($ reflections $)=0.0743(4642) \mathrm{wR} 2($ reflections $)=0.1608(5992)$

$\mathrm{S}=1.098 \mathrm{Npar}=435$ 


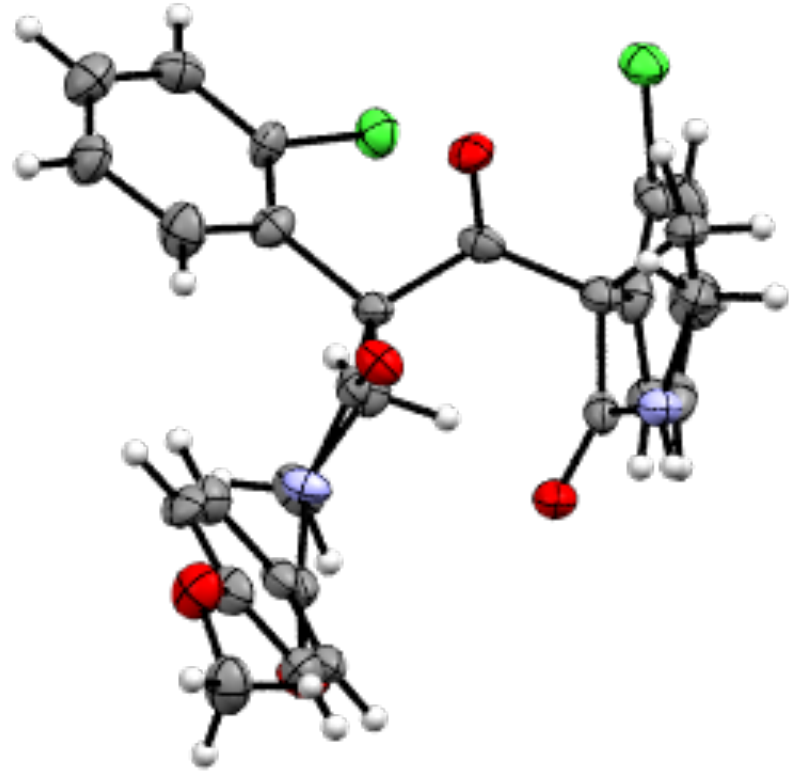

Crystal data and structure refinement for $29 d$.

Bond precision: $\mathrm{C}-\mathrm{C}=0.0088$ A Wavelength $=1.54178$

Cell: $a=14.8617(8) b=10.0463(7) c=17.6899(11)$

alpha $=90$ beta $=103.410(4)$ gamma $=90$

Temperature: $100 \mathrm{~K}$

Calculated Reported

Volume 2569.2(3)

Space group P 21/c

Hall group -P 2ybc

Moiety formula C29 H24 Cl2 N2 O5

Sum formula C29 H24 C12 N2 O5

$\operatorname{Mr} 551.40$

Dx,g cm-3 1.426

Z 4 
$\mathrm{Mu}(\mathrm{mm}-1) 2.642$

F000 1144.0

F000' 1150.12

$\mathrm{h}, \mathrm{k}, \operatorname{lmax} 18,12,20$

Nref 4763

Tmin,Tmax 0.630,0.750

Tmin' 0.768

Correction method $=$ \# Reported T Limits: Tmin $=0.630$

Tmax $=0.750$ AbsCorr $=$ MULTI-SCAN

Data completeness $=0.967$ Theta $(\max )=70.650$

$\mathrm{R}($ reflections $)=0.0759(2459) \mathrm{wR} 2($ reflections $)=0.2336(4763)$

$\mathrm{S}=0.963 \mathrm{Npar}=344$ 


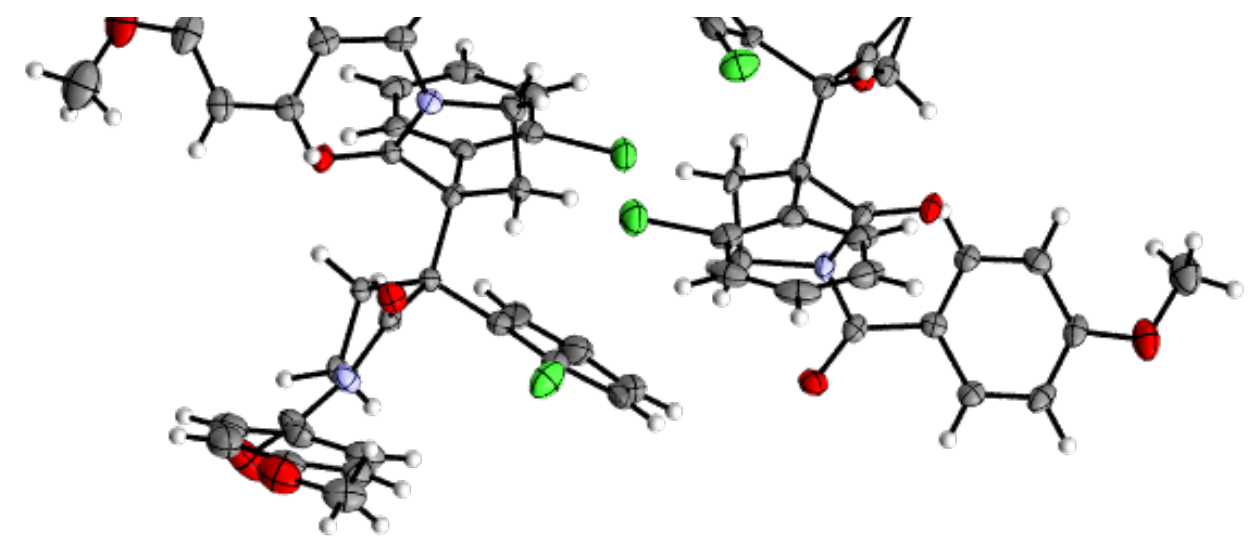

Crystal data and structure refinement for $\mathbf{3 0 d}$.

Cell: $a=13.3122(3) b=20.4330(5) c=22.1795(5)$

alpha $=90$ beta $=90$ gamma $=90$

Temperature: $100 \mathrm{~K}$

Calculated Reported

Volume 6033.0(2)

Space group P n a 21

Hall group P 2c -2n

Moiety formula C36 H30

$\mathrm{C} 12 \mathrm{~N} 2 \mathrm{O} 6$

Sum formula C36 H30 Cl2 N2 O6

Mr 657.52

Dx,g cm-3 1.448

Z 8

$\mathrm{Mu}(\mathrm{mm}-1) 2.374$ 
F000 2736.0

F000' 2757.53

h,k, $\operatorname{lmax} 15,23,26$

Nref 9886

Tmin,Tmax 0.796,0.909

Tmin' 0.491

Correction method $=$ Not given

Data completeness $=1.68 / 0.86 \operatorname{Theta}(\max )=69.977$

$\mathrm{R}($ reflections $)=0.0607(9196) \mathrm{wR} 2($ reflections $)=0.1753(9886)$

$\mathrm{S}=1.025 \mathrm{Npar}=835$ 


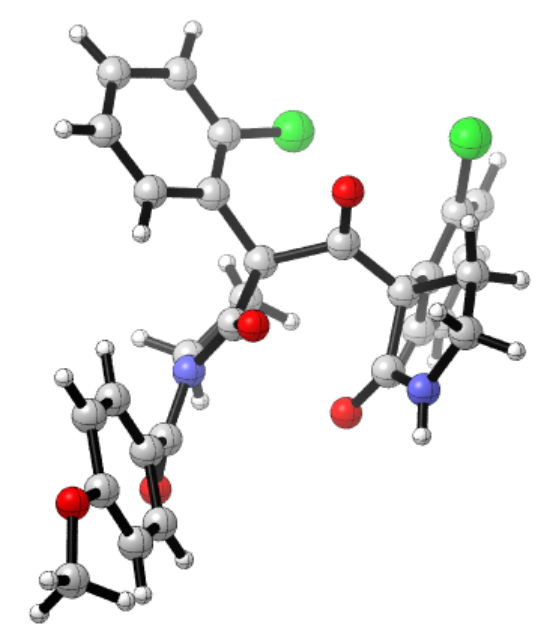

MicroED crystal structure and data processing statistics of 29d.

Cell: $\mathrm{a}=14.460(3) \mathrm{b}=9.920(2) \mathrm{c}=17.530(4)$

alpha $=90$ beta $=103.69(2)$ gamma $=90$

Temperature: $293 \mathrm{~K}$

Volume 2443.1(9)

Space group P 21/c

Hall group -P 2ybc

Moiety formula C29 H24 Cl2 N2 O5

Sum formula C29 $\mathrm{H} 24 \mathrm{Cl} 2 \mathrm{~N} 2 \mathrm{O} 5$

Mr 551.40

Z 4

Resolution $1.1 \AA$

Completeness $96.3 \%$

$R=0.1539$

$w R 2=0.3962$

$G o o F=1.79$ 


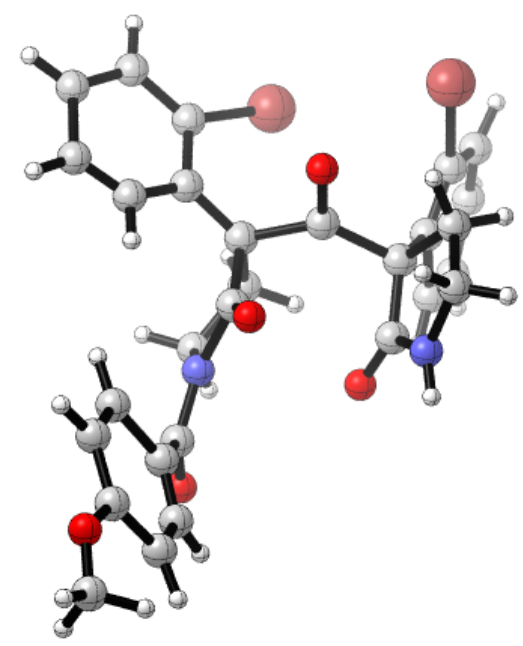

MicroED crystal structure and data processing statistics of 29e.

Cell: $a=14.160(3) b=9.900(2) c=17.190(3)$

alpha $=90$ beta $=102.18(2)$ gamma $=90$

Temperature: $293 \mathrm{~K}$

Volume 2355.5(8)

Space group P 21/c

Hall group -P 2ybc

Moiety formula C29 H24 Br2 N2 O5

Sum formula C29 H24 Br2 N2 O5

Mr 640.32

Z 4

Resolution $1.2 \AA$

Completeness $92.0 \%$

$R=0.1660$

$w R 2=0.4141$

$G o o F=2.108$ 


\section{${ }^{1}$ H NMR Spectra:}



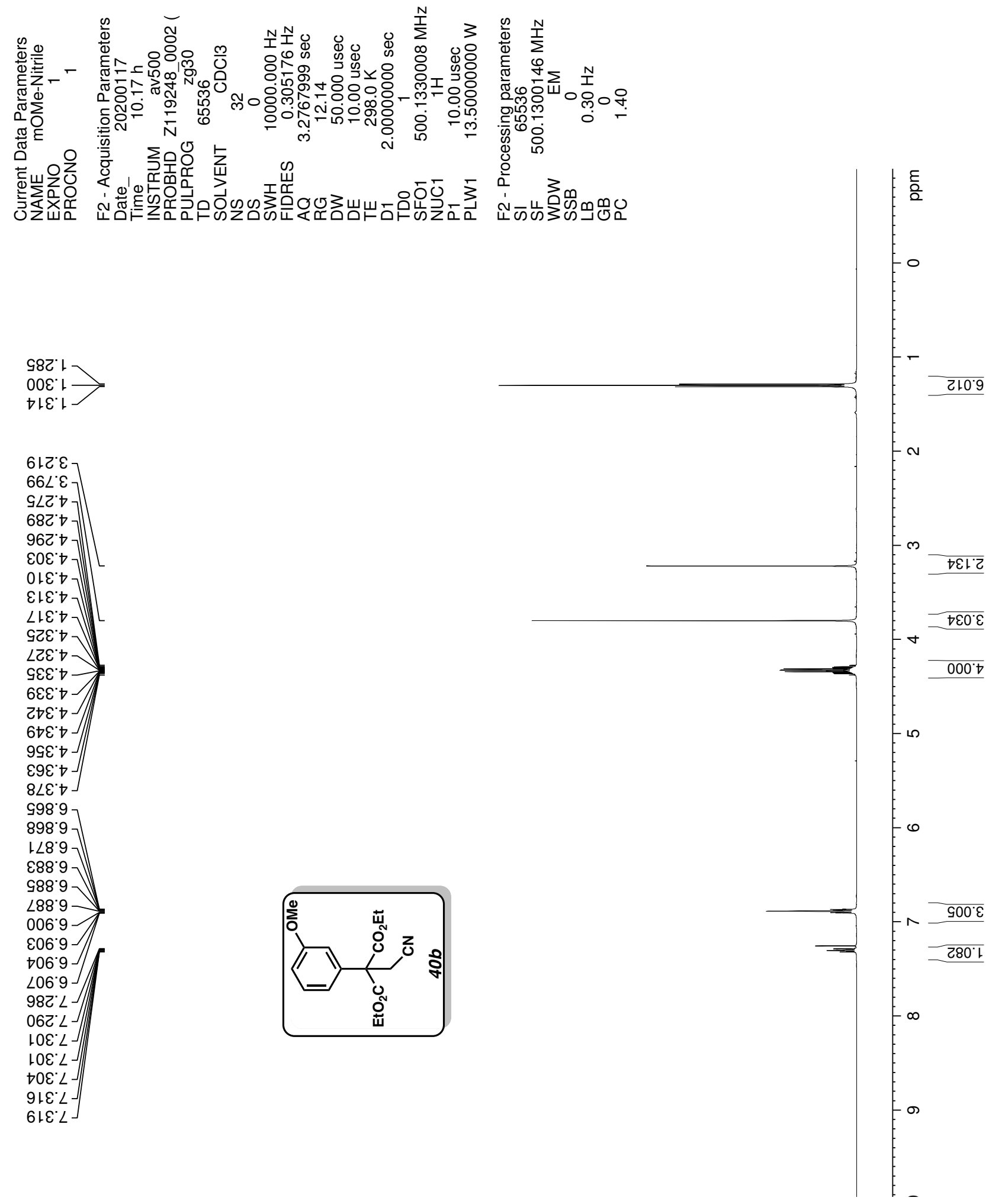

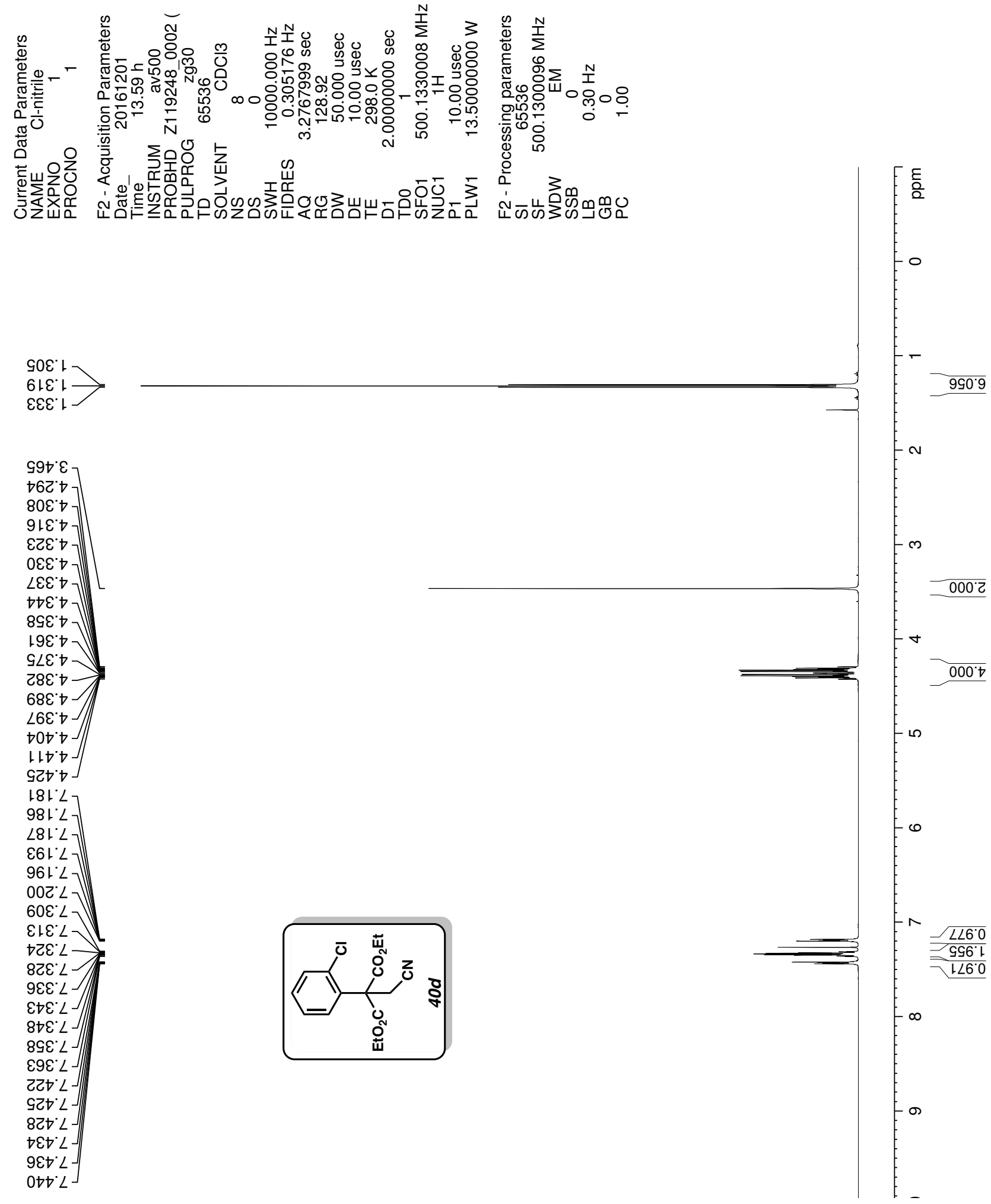

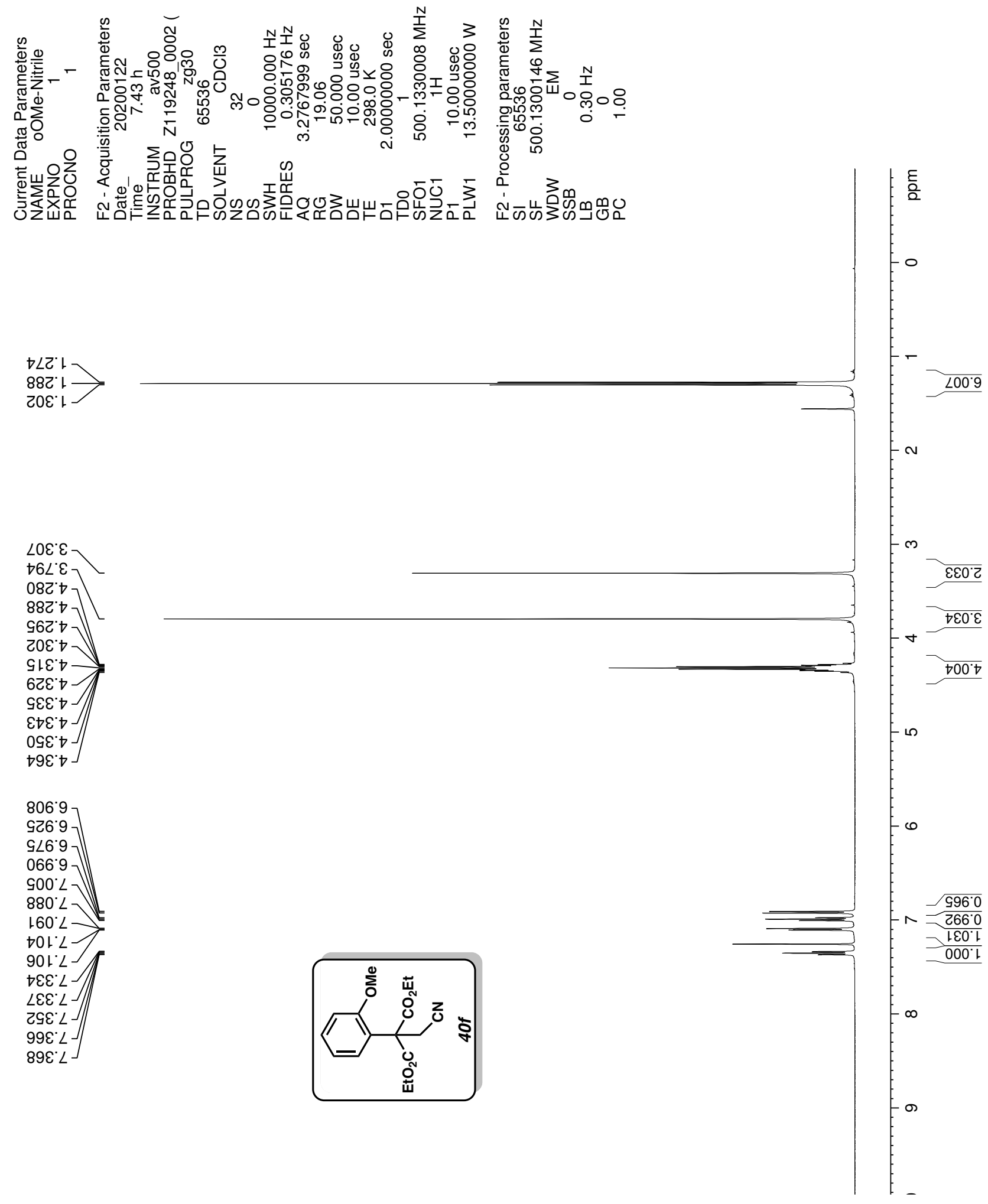

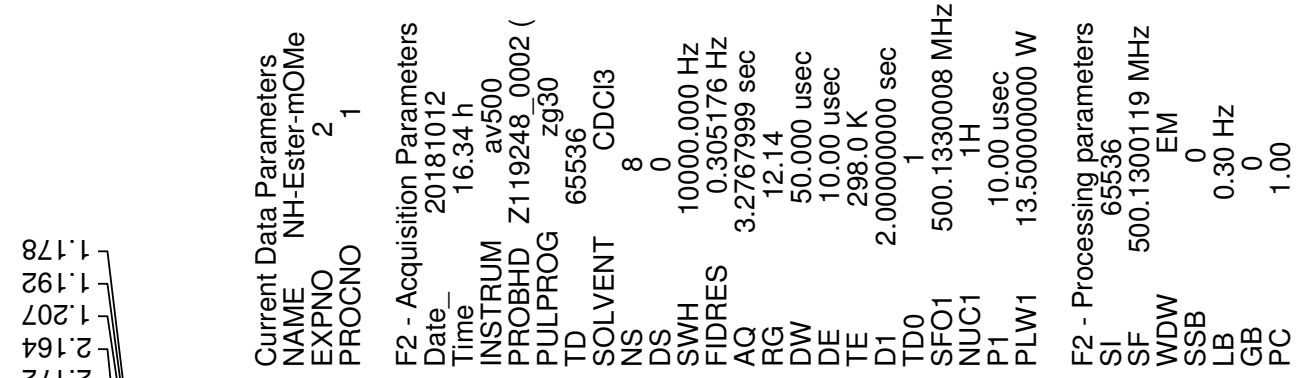

ZLI'Z]

$\left.6 \angle L^{\circ} \mathrm{C}\right]$

$881^{\prime} \mathrm{Z}$

$06 L^{\circ} \mathrm{Z}$

$86 \mathrm{I}^{\circ} \mathrm{]}$

902'

$\left.\varepsilon เ \tau^{\prime} 乙\right]$

ต $\left.8 เ^{\circ} \varepsilon\right]$

$\left.68{ }^{\circ} \varepsilon\right]$

$66 \mathrm{r}^{\circ} \mathcal{E}$

$\varepsilon 0 \tau^{\circ} \varepsilon$

$\left.8 เ \nearrow^{\circ} \varepsilon\right]$

06ट' $\varepsilon$ ]

$\supset 0 \varepsilon^{\circ} \varepsilon$ ]

$90 \varepsilon^{\cdot} \varepsilon$

$91 \varepsilon^{\cdot} \varepsilon$

$0 \varepsilon \varepsilon^{\circ} \varepsilon$

$\varepsilon \varepsilon \varepsilon^{\prime} \varepsilon$

$9 \sqcup \varepsilon^{\circ} \varepsilon$

ट9๑ $\varepsilon$

$\left.0 \angle \nabla^{\cdot} \varepsilon\right]$

$\neg 8 L^{\circ} \varepsilon-$

$60{ }^{\circ} \rightarrow$

$\varepsilon 己+\circ$

LEเ $\downarrow$

詁・

$\angle 8 C^{\prime} \nabla$

เ०ع' $\nabla$

$60 \varepsilon^{\circ} \triangleright$

$\varepsilon 乙 \varepsilon^{\circ} \triangleright$

$0 \angle 8^{\circ} 9$

टL8 9

$988^{\circ} 9$

$888^{\circ} 9$

टह6.9

$\downarrow \varepsilon 6^{\circ} 9$

$\angle \nabla 6{ }^{\circ} 9$

$6+6.9$

ट96.9

796.9

$86 L^{\circ} L$

$\angle G Z^{\prime} \angle-$

$09 Z^{\circ} L$

$\varepsilon L Z^{\prime} L$

$\nabla \angle Z^{\prime} L$

$9 L Z^{\prime} L$

$\angle L Z^{\prime} \angle-$

$68 C^{\circ} L$ 

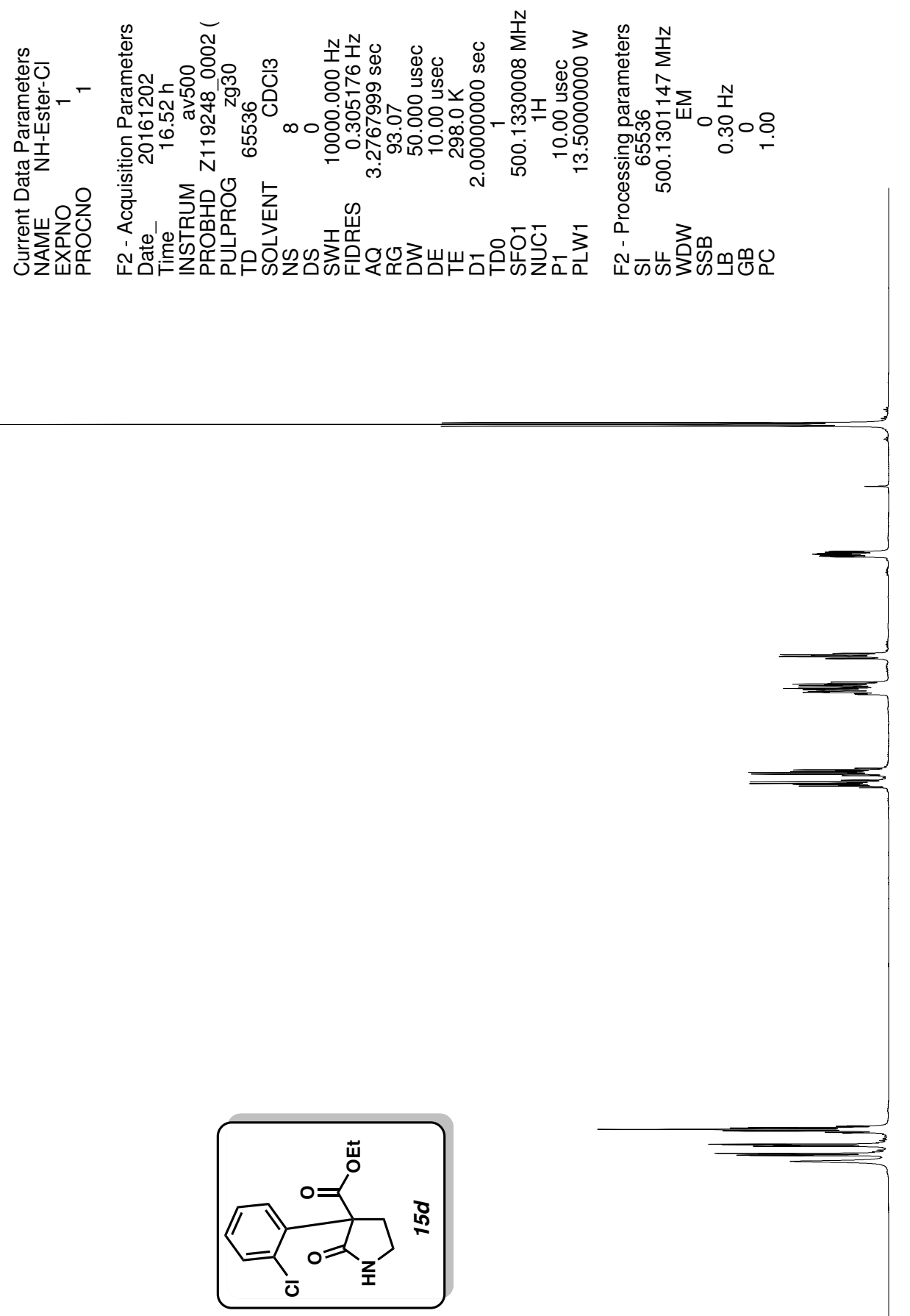

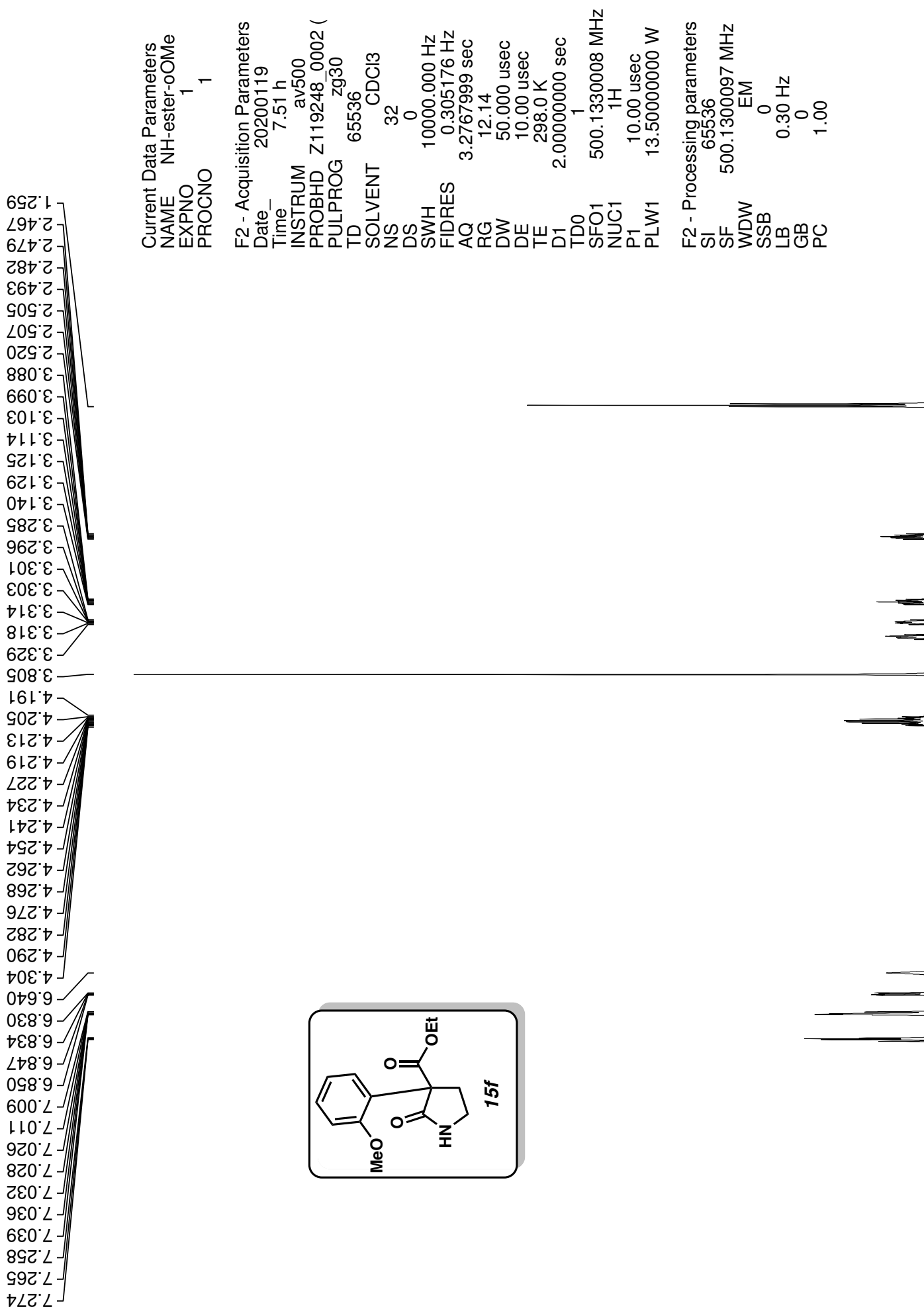

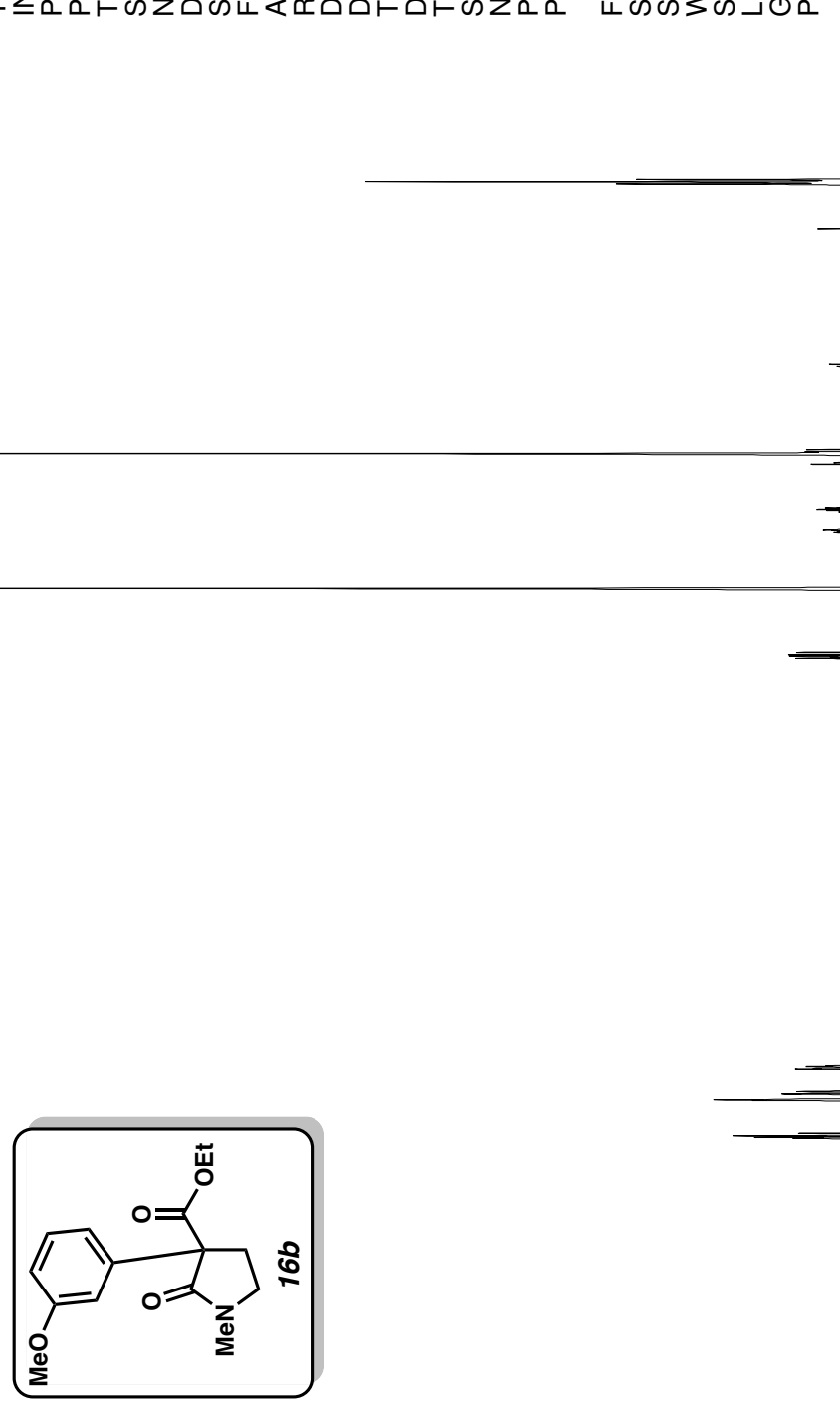

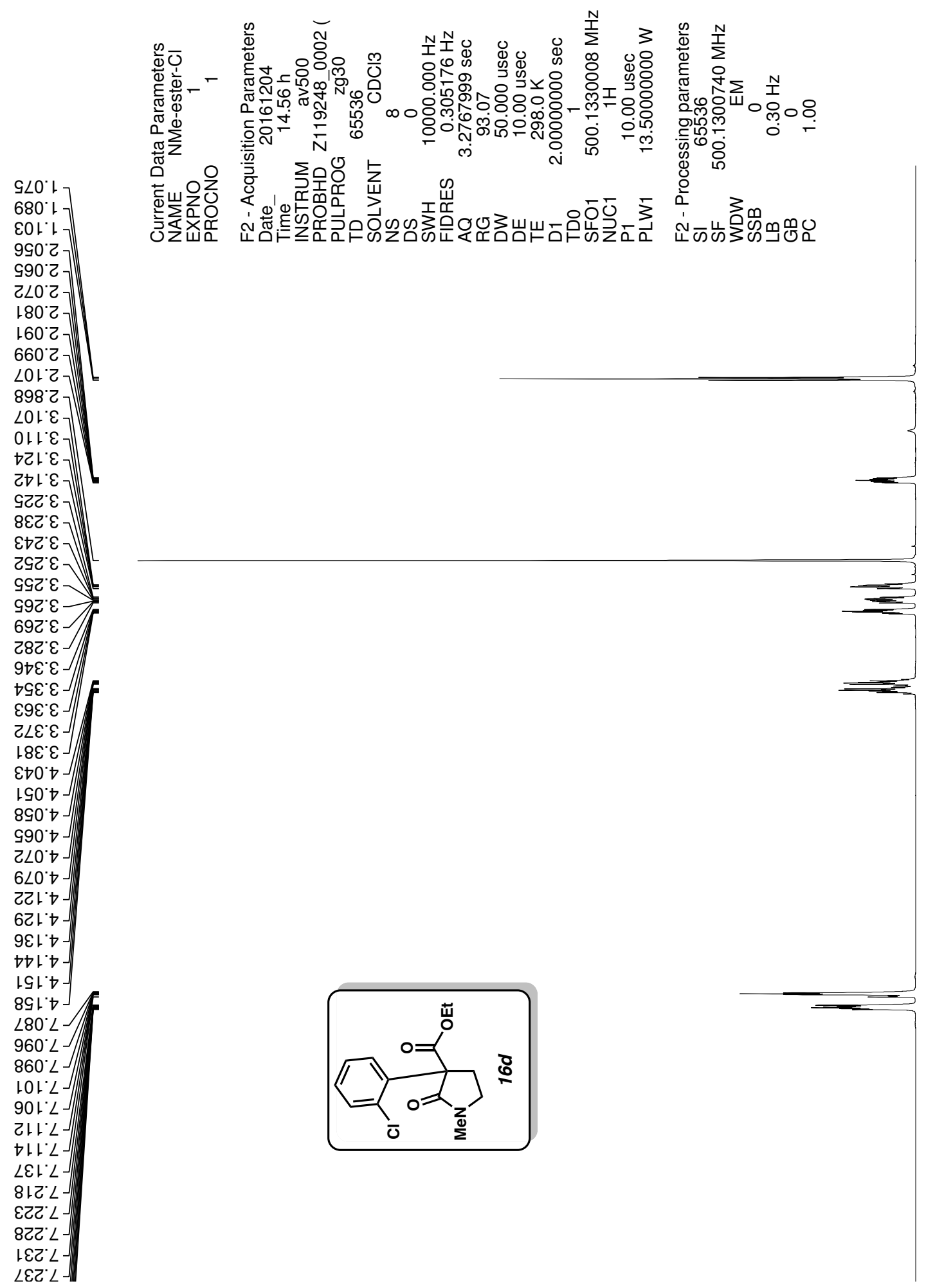


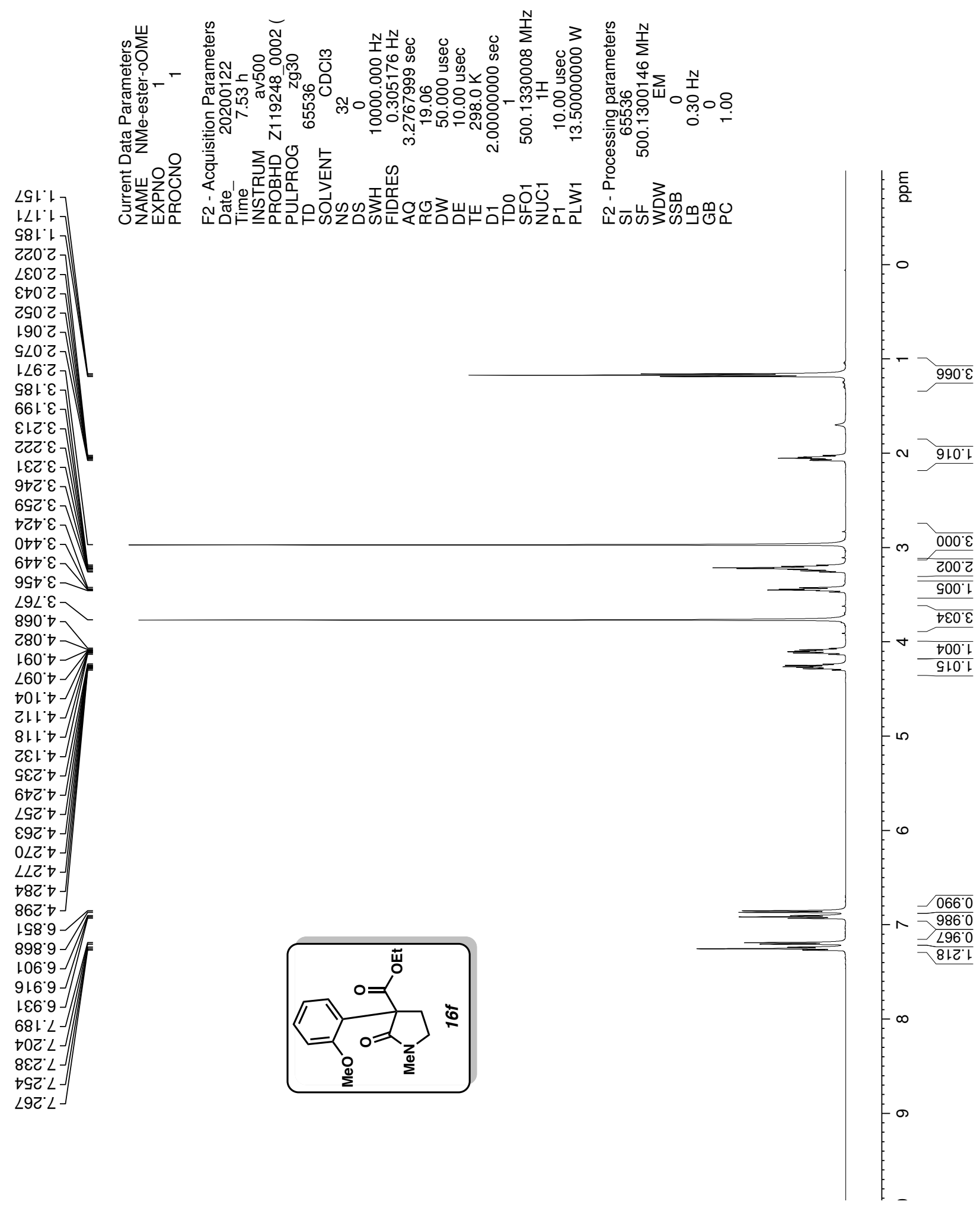




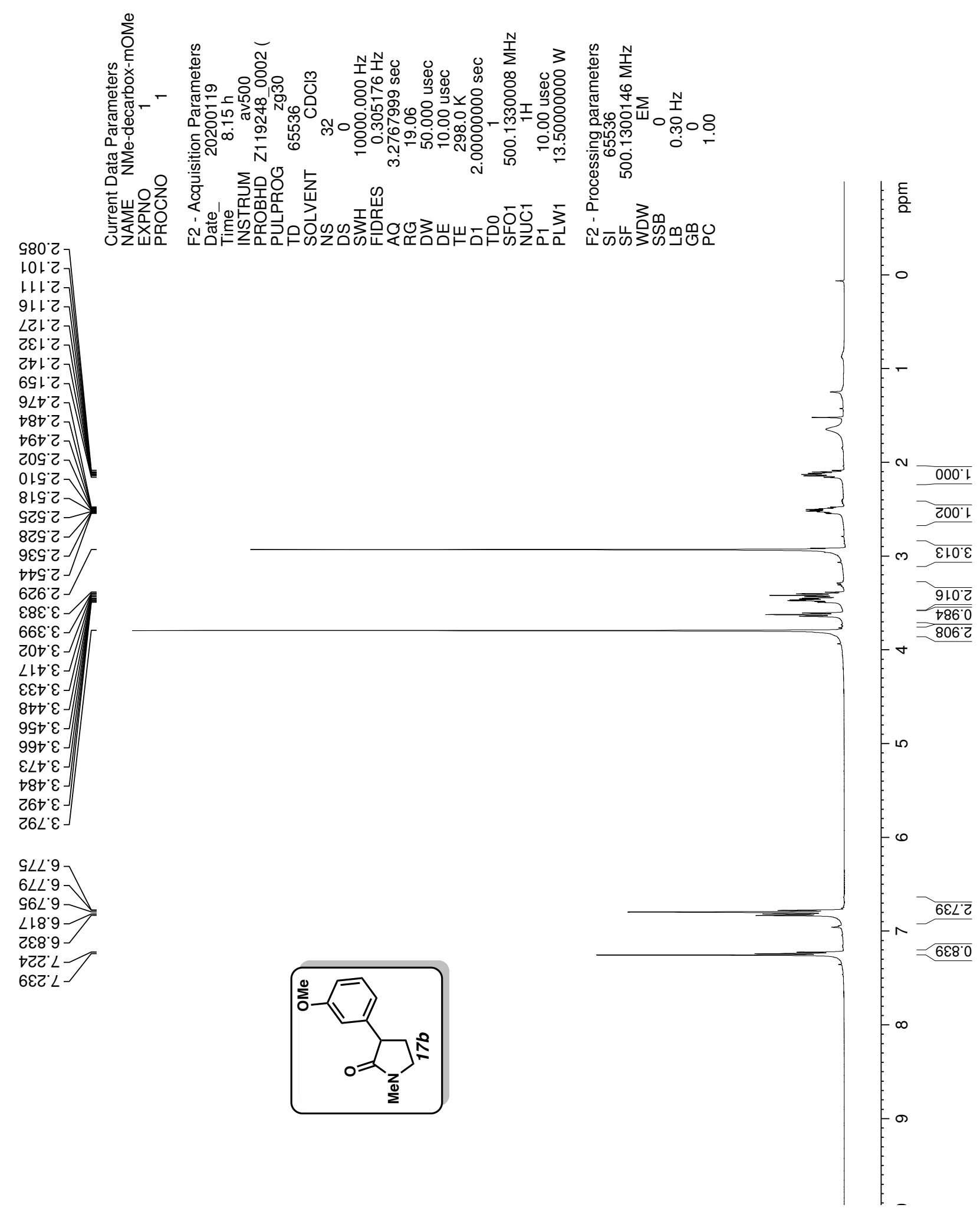



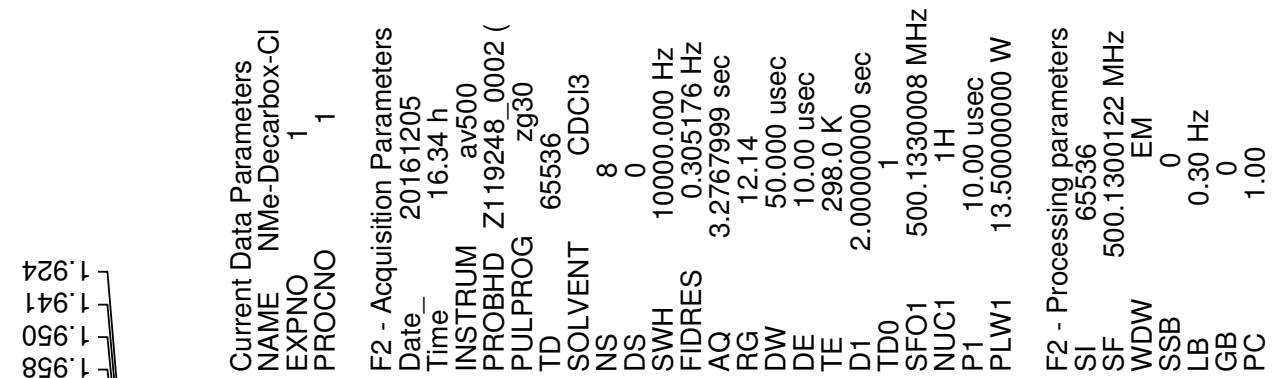

$\angle 96^{\circ}$ '

SL6.

$786^{\circ} \vdash$

$100^{\circ} \mathrm{C}$

$8 \angle G^{\prime} Z$

$\left.\angle 89^{\prime} 2\right]$

$269^{\prime} Z$

$\left.\angle 6 S^{\circ} \mathrm{C}\right]$

$009 \cdot 2]$

$909^{\circ} \mathrm{Z}$

म19.

ट19. 2

619.2

Eट9' $\mathrm{冫}$

9ट9"ح

टह9'乙

$\angle \varepsilon 9^{\circ} Z$

St9' $\mathrm{C}$

ZL6 $2-$

$6 เ \nabla^{\circ} \varepsilon-$

$\left\lfloor\varepsilon \nabla^{\circ} \varepsilon-\right.$

$\left.8 \varepsilon \nabla^{\circ} \varepsilon\right][$

क N

ले

ํํ ํำ

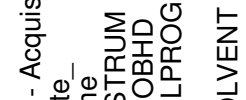

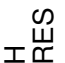

뜌.

$19 t^{\circ} \varepsilon$

$160 \circ \div$

$60+t$

$82+\circ$

$0 \angle L^{\circ} \angle$

$\nabla \angle L \angle$

$\nabla 8 L^{\circ} \mathrm{L}$

$98 L^{\circ} \mathrm{L}$

$88 L^{\circ} L$

$06 \mathrm{~L}^{\circ} \mathrm{L}$

$76 \mathrm{~L}^{\circ} \mathrm{L}$

$66 \mathrm{I}^{\circ} \mathrm{L}$

$\varepsilon 0 Z^{\prime} L$

$902 ' \angle$

$602 \mathrm{~L}$

$\varepsilon Z Z \angle J$

9टZ $L$

$\angle \varepsilon Z \angle$

$6 \varepsilon \mathcal{C}^{\circ} \angle$

$\varepsilon \nabla Z \cdot L$

ESट ' $L$

9Sट $L-$

$09 \varepsilon^{\circ} L$

ट9\& $L$

$\varepsilon 9 \varepsilon^{\circ} \angle-$

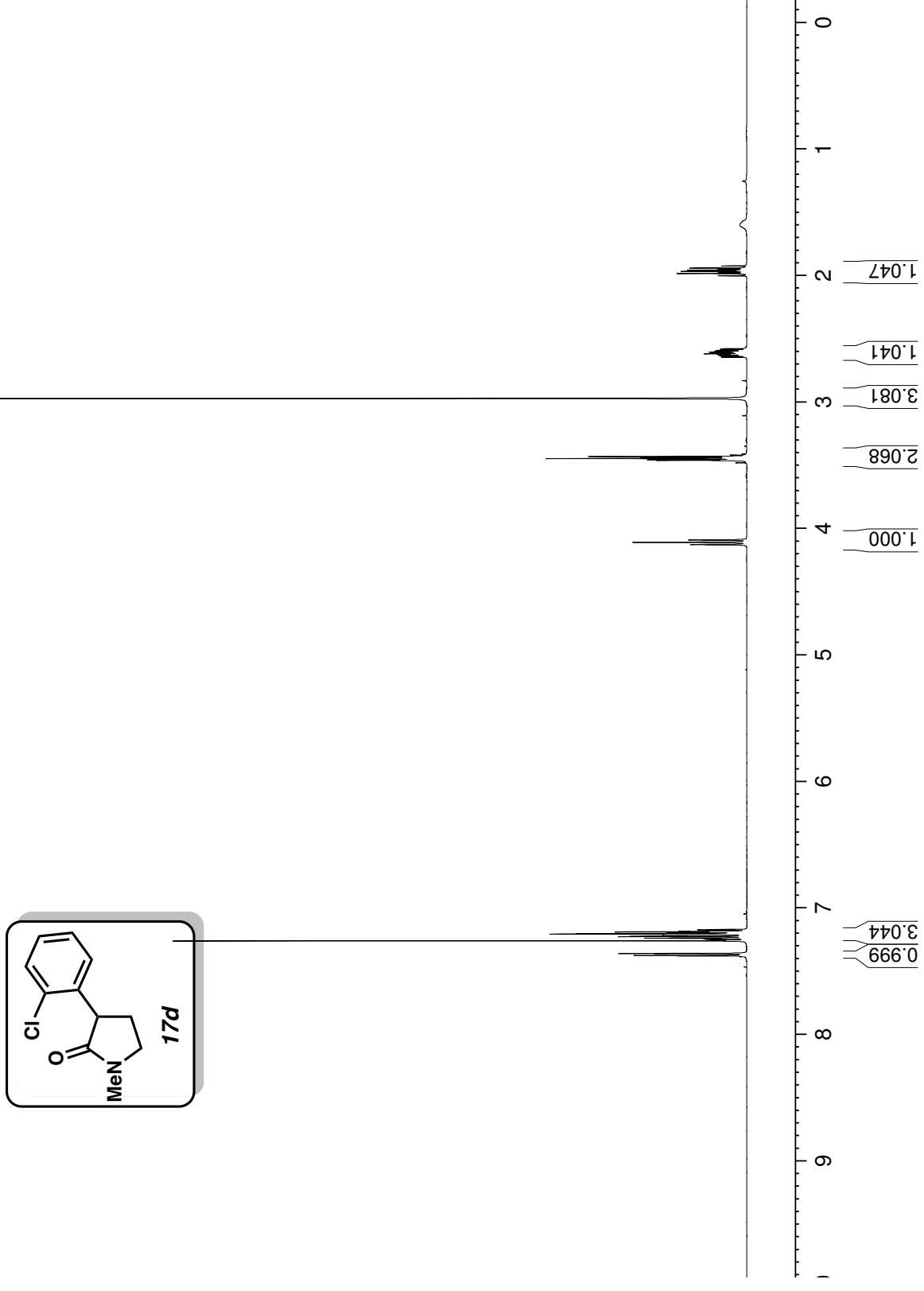




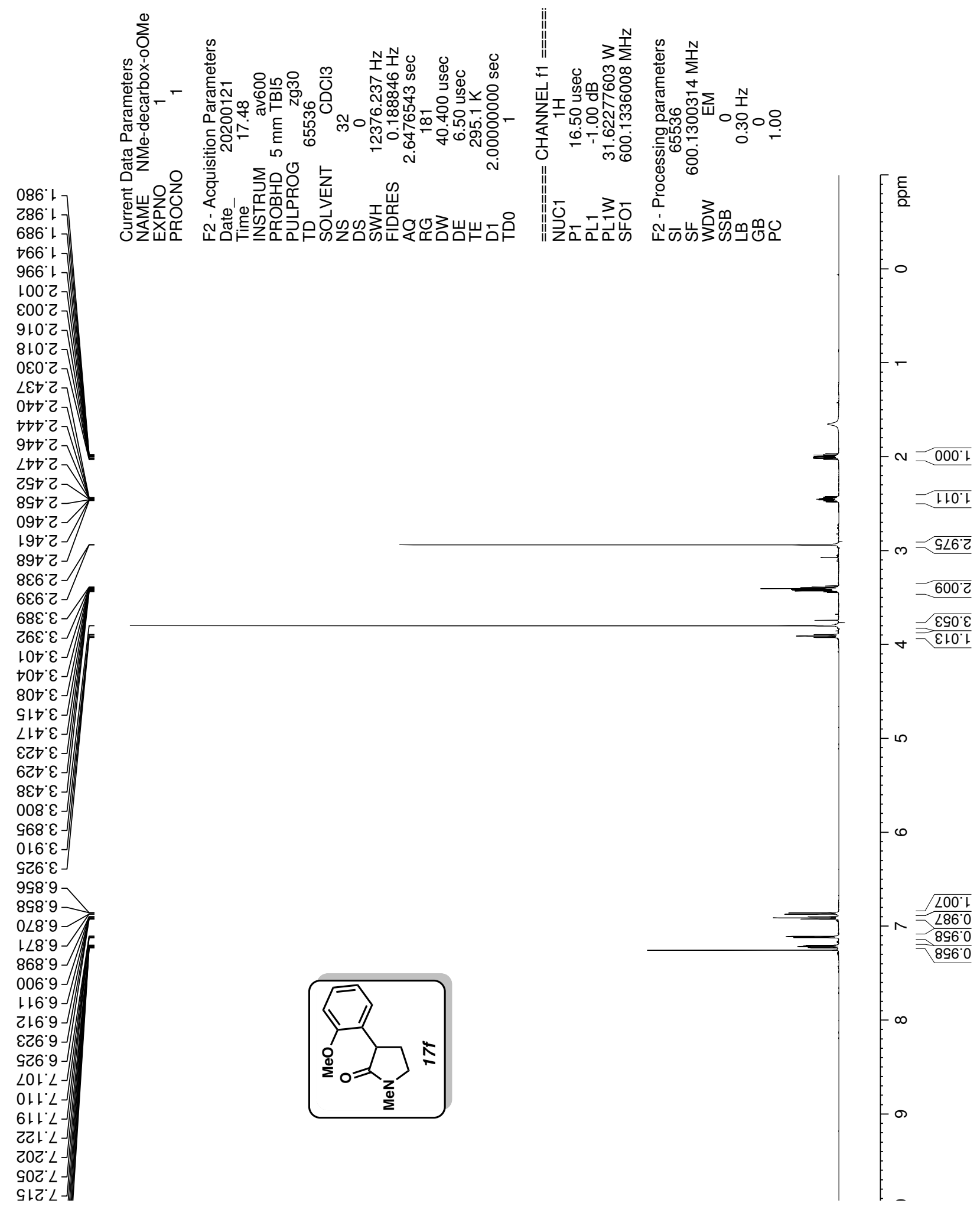



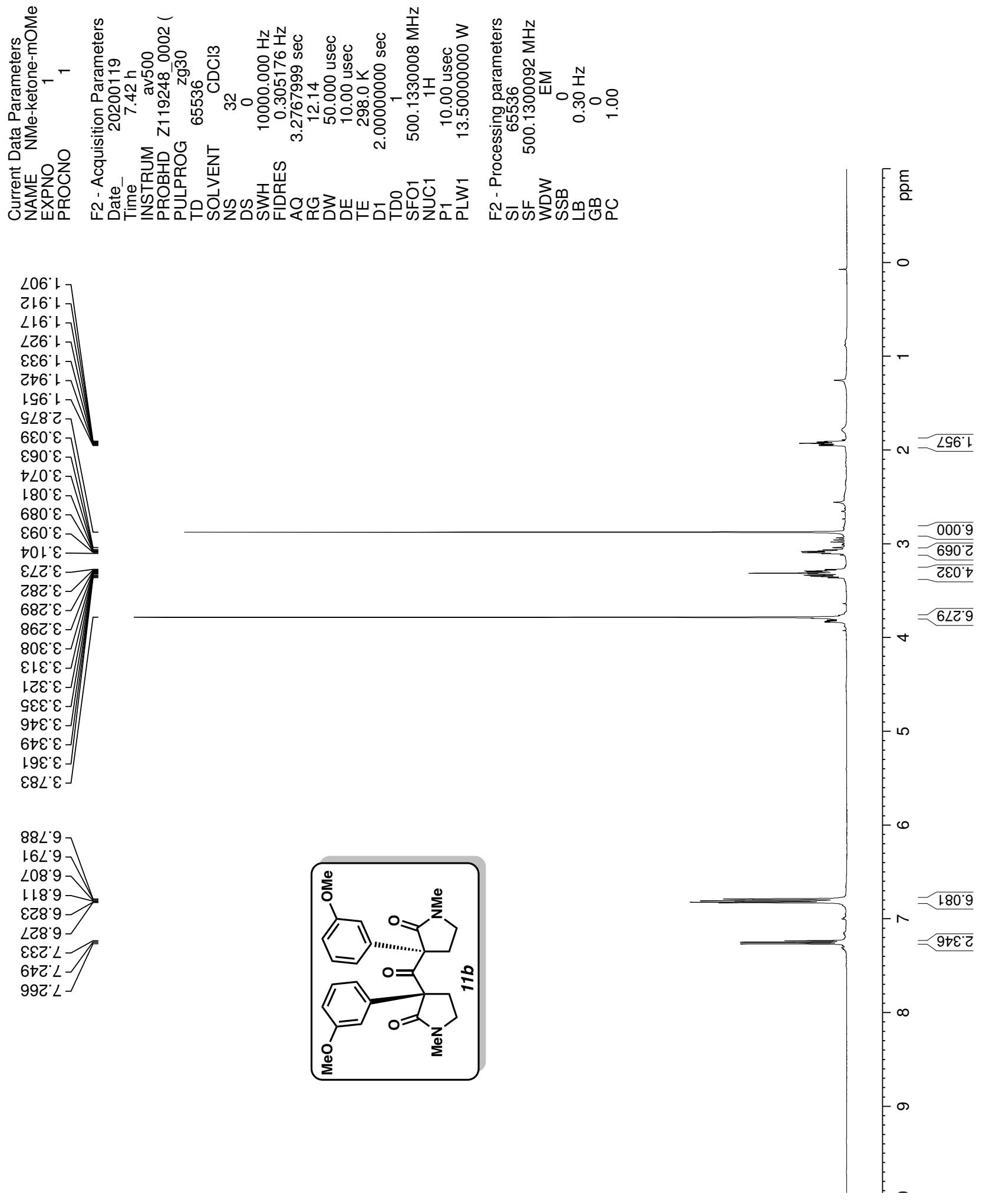

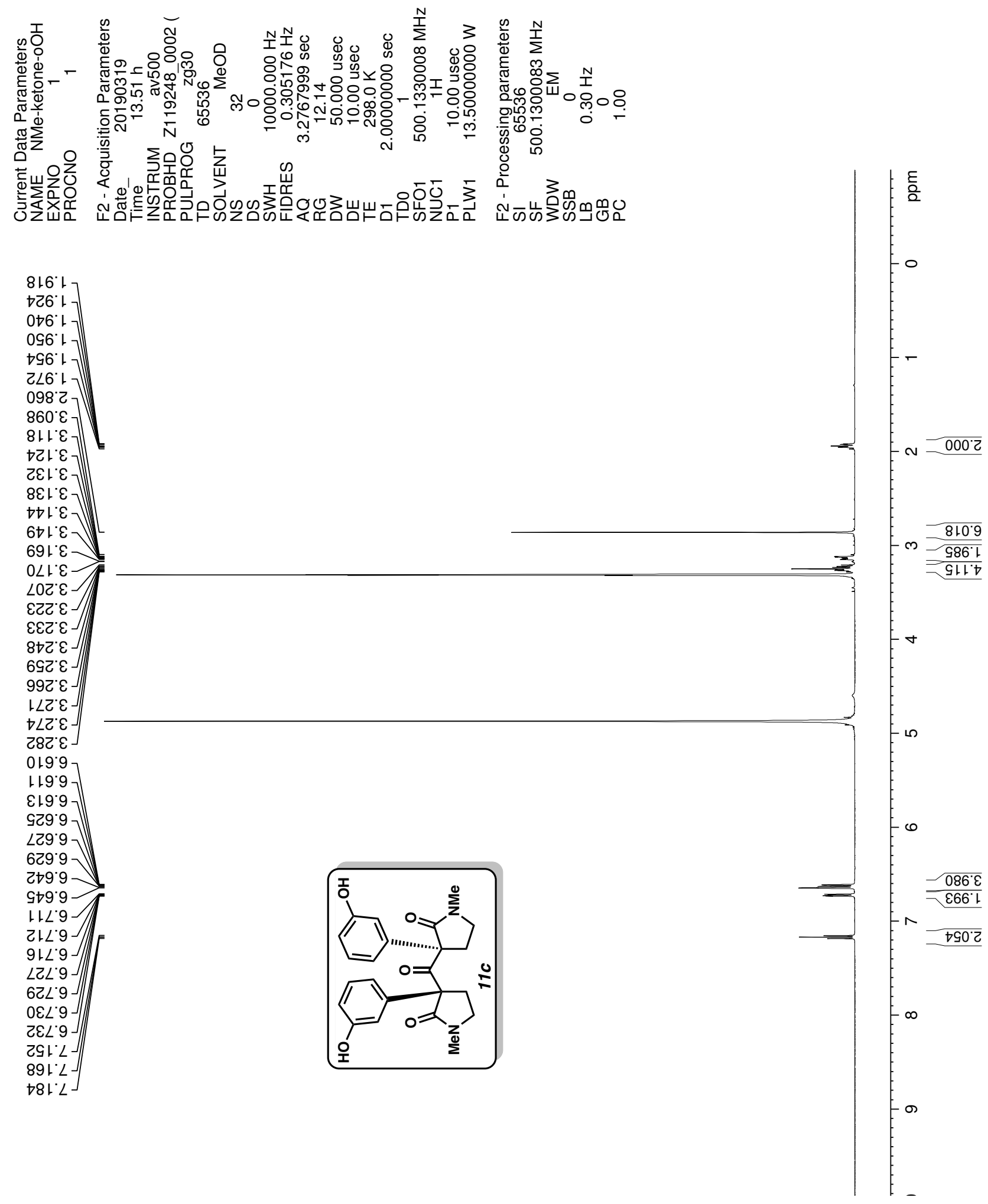

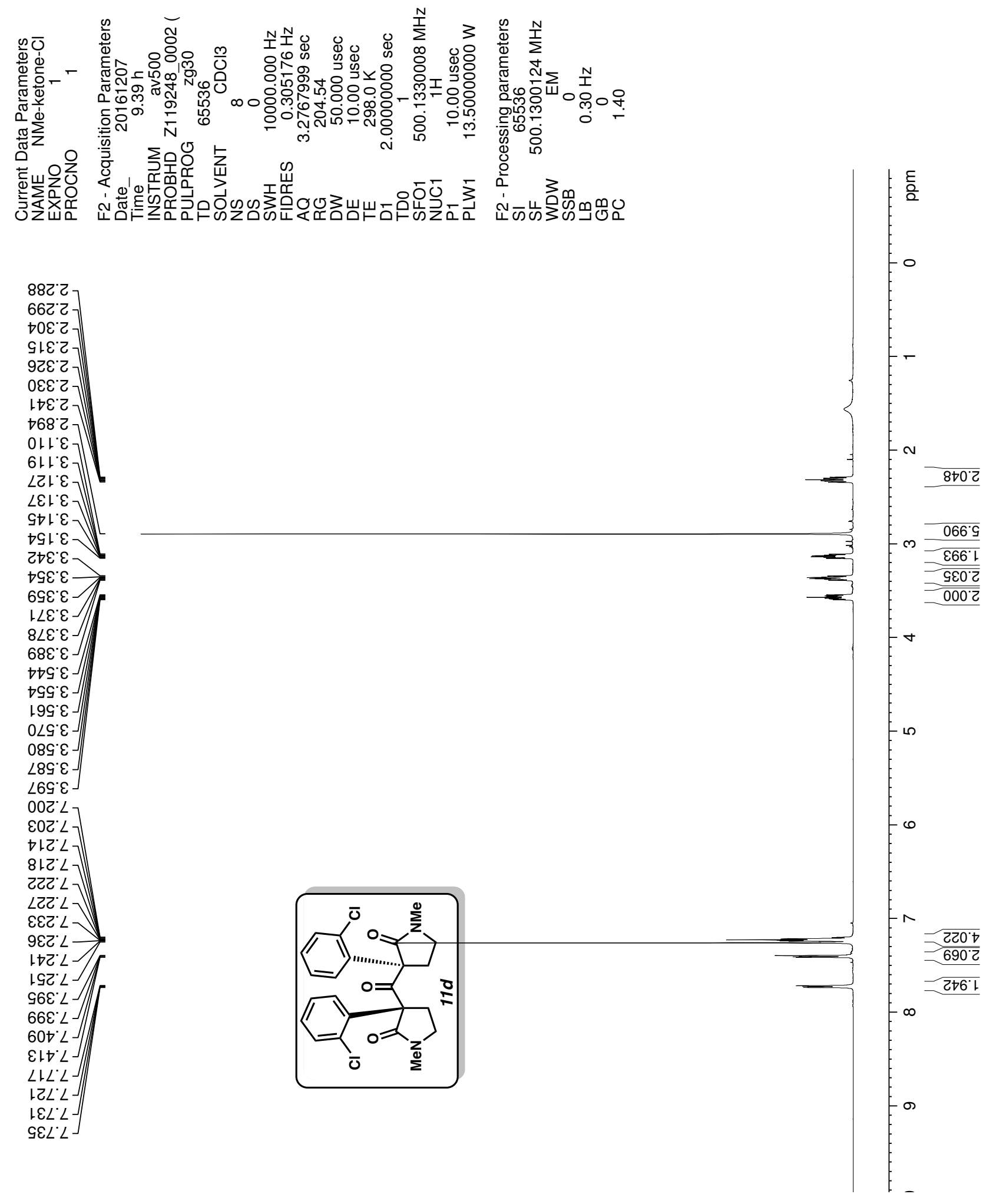

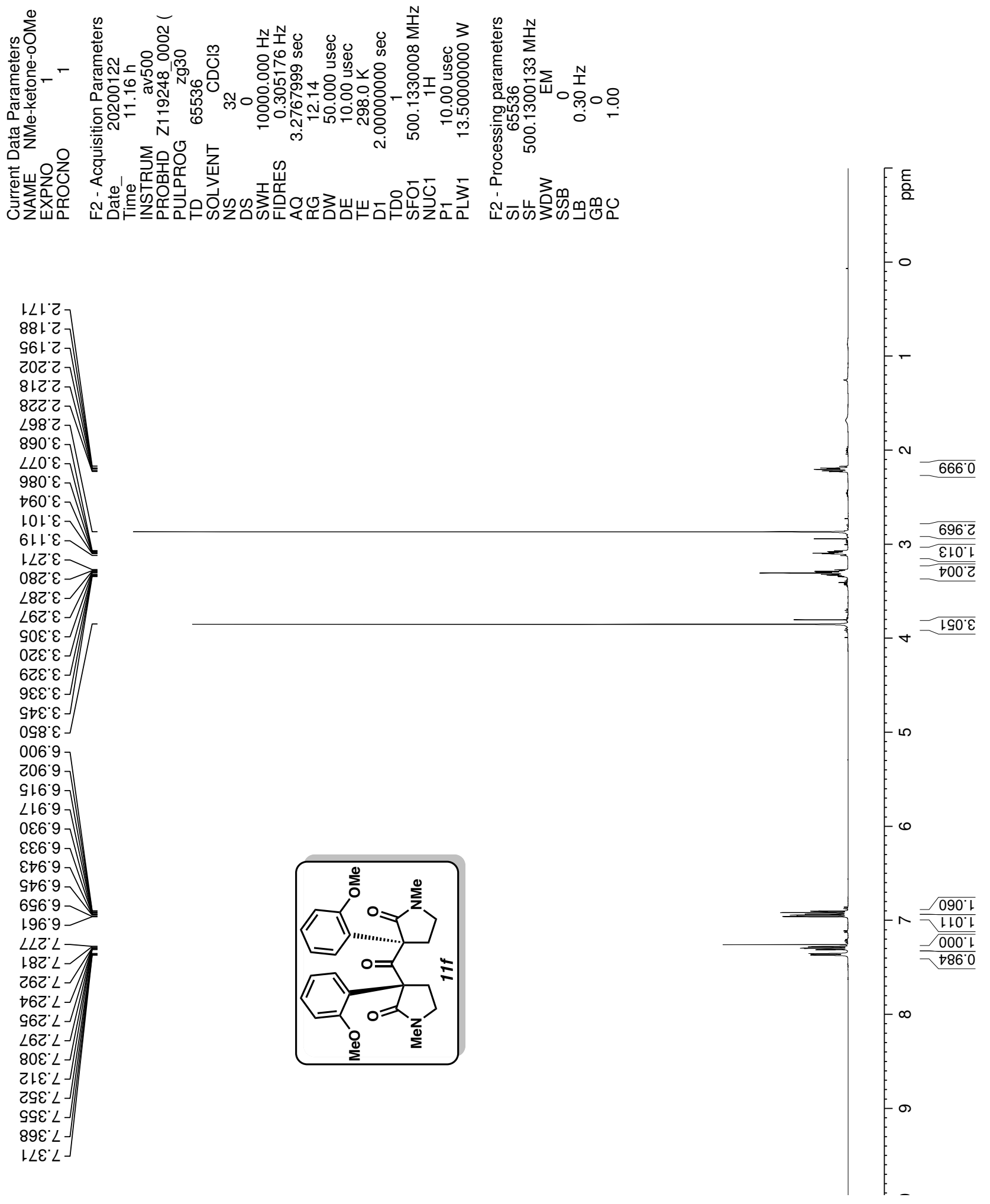

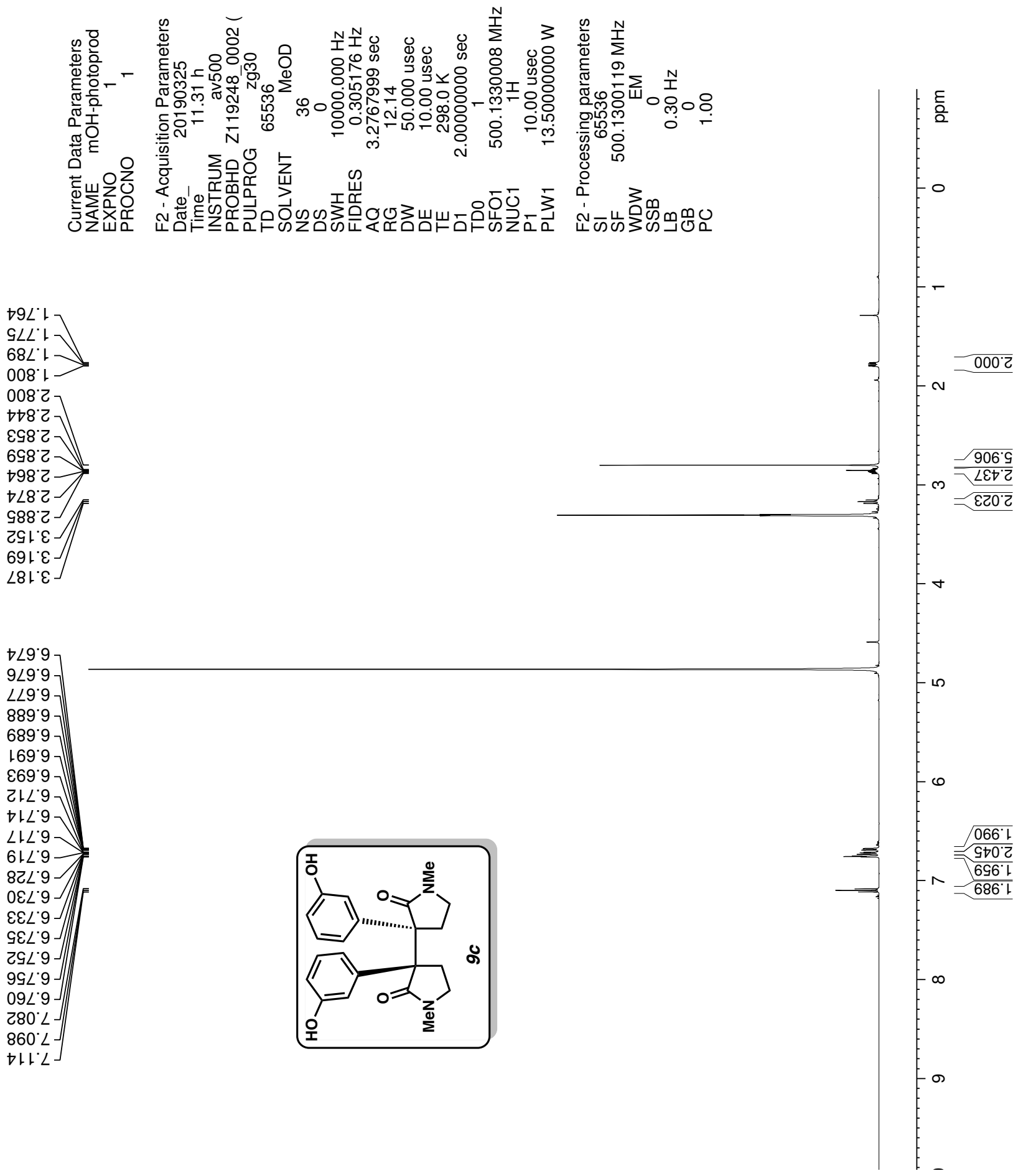

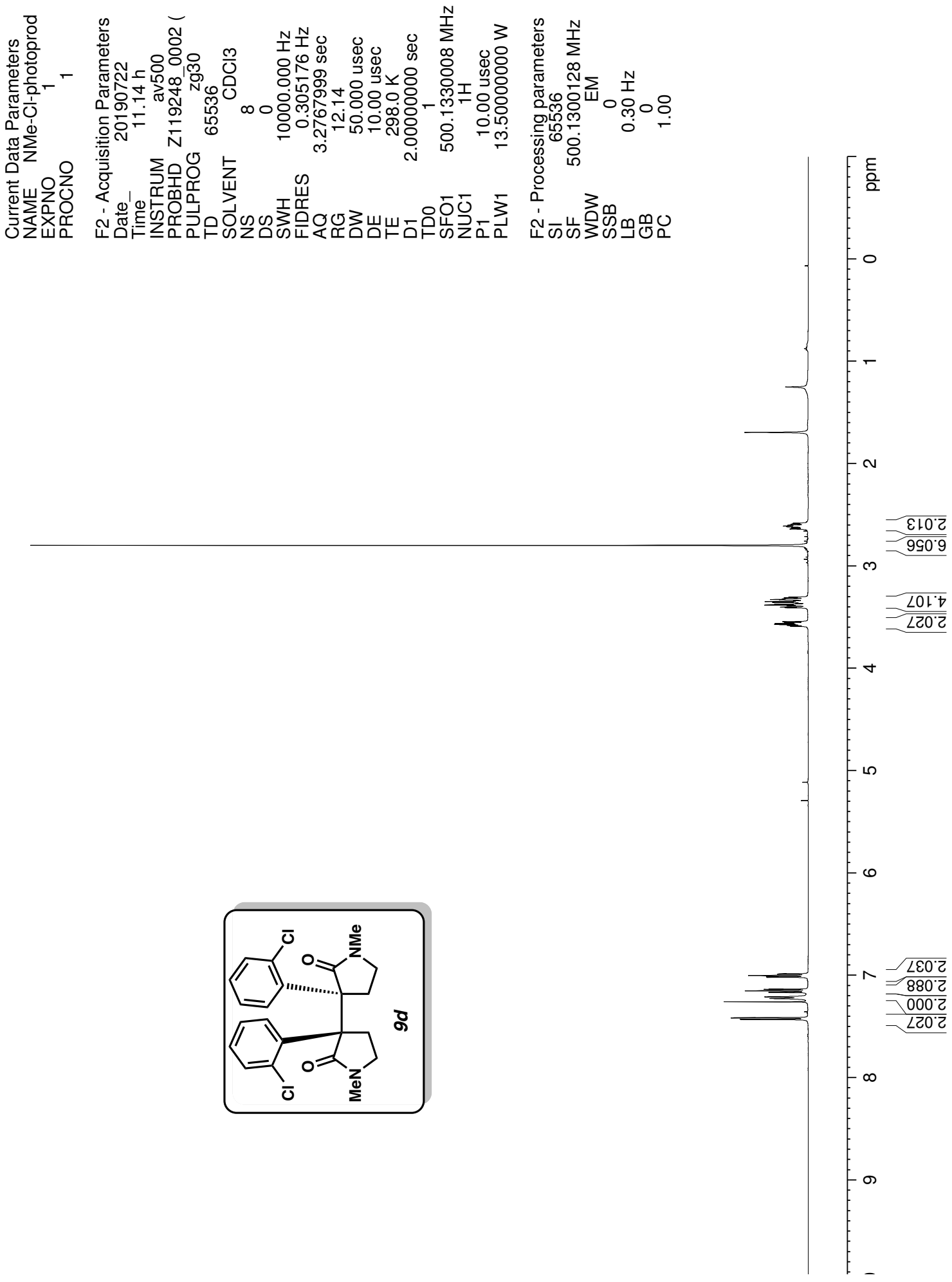

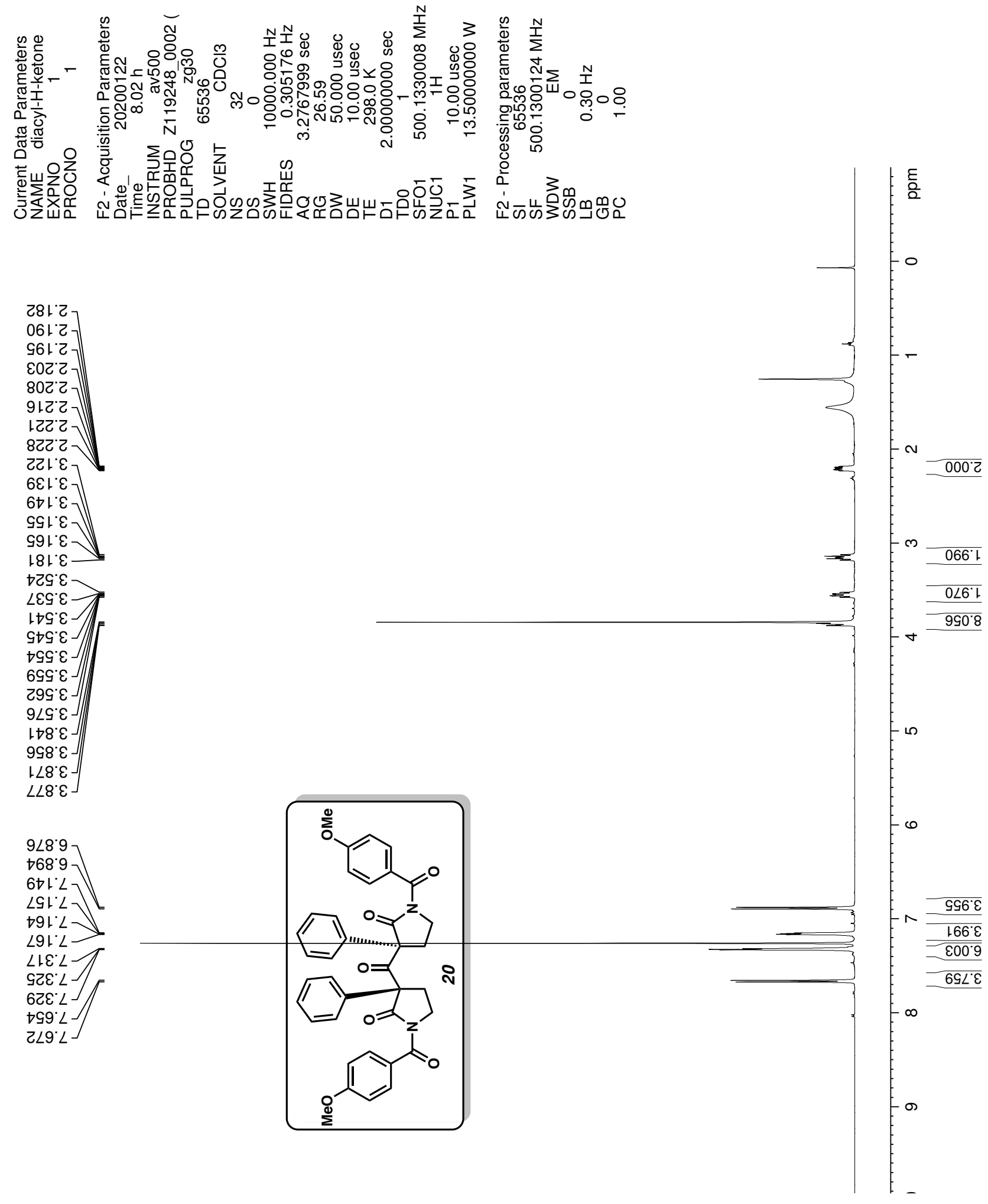

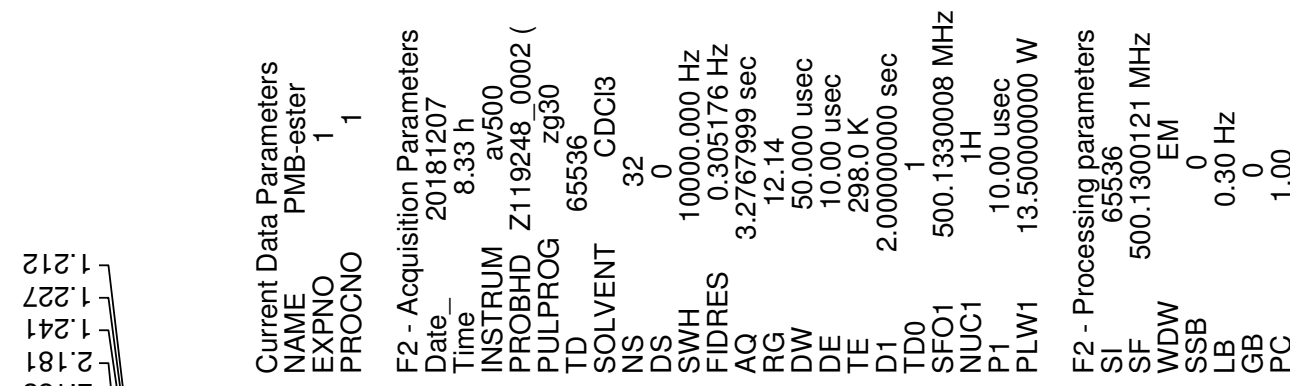

$\varepsilon 8 L^{\circ} \mathrm{Z}$

$16+2$

$66+2]$

$\varepsilon 80^{\circ} \varepsilon$

$980^{\circ} \varepsilon$

$880^{\circ} \varepsilon$

$860^{\circ} \varepsilon$ ]

$\left.\angle L^{\circ} \varepsilon\right]$

$80 \varepsilon^{\circ} \varepsilon$

$\left\llcorner 乙 \mathcal{E}^{\cdot} \varepsilon\right]$

$\left.\downarrow \varepsilon \varepsilon^{\circ} \varepsilon\right]$

$\left.\nabla \downarrow \varepsilon^{\circ} \varepsilon\right]$

$\angle \triangleright \varepsilon^{\circ} \varepsilon$ ᄀ

$\left\lfloor G \mathcal{E}^{\circ} \mathcal{E}\right.$ ]

ट9६ $\varepsilon$ -

$69 \varepsilon^{\circ} \varepsilon \vee$

$008^{\circ} \varepsilon$

$00{ }^{\circ} \dagger$

งเこ๋

乙टで॰

$9 \varepsilon ट \bullet$

09ट"

GLZ'

ट८ट॰

962 $\downarrow$

งฺt॰

๑8 $\bullet$

टLS" $\downarrow$

109 5

$\angle 98^{\circ} 9$

$1 \angle 8^{\circ} 9$

$088^{\circ} 9$

$\neg 88^{\circ} 9$

GOZ' $L$

$80 Z^{\circ} L$

टIC'L

$912 \cdot L$

$\varepsilon ट Z L^{\circ}-$

GटZ $\angle-$

$\angle Z Z \angle$

6ZZ' $L$

$\angle E Z^{\prime} L-$

$\angle \mathcal{L} \varepsilon^{\circ} \angle-$

$\circlearrowright \succ \varepsilon \cdot L-$

$\nabla \nabla \varepsilon^{\circ} L-$

$\angle \downarrow \varepsilon^{\prime} \angle$

LGE $L$

$9 S \varepsilon^{\circ} L$

$\neg 9 \varepsilon^{\circ} \angle-$

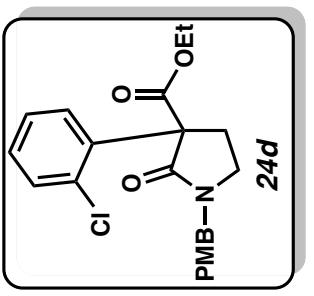

$-\infty$

$000^{\circ}$

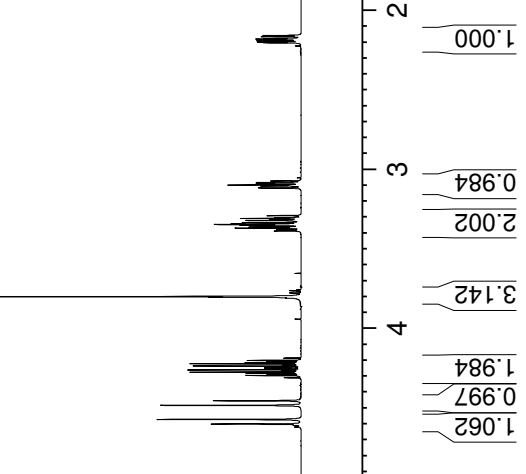

- 10

6

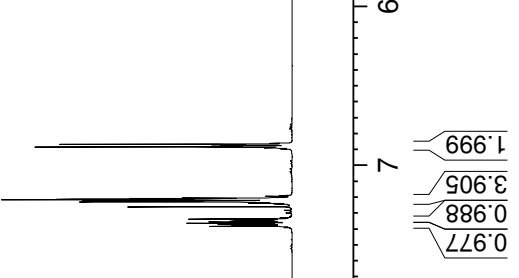

$-\infty$ 


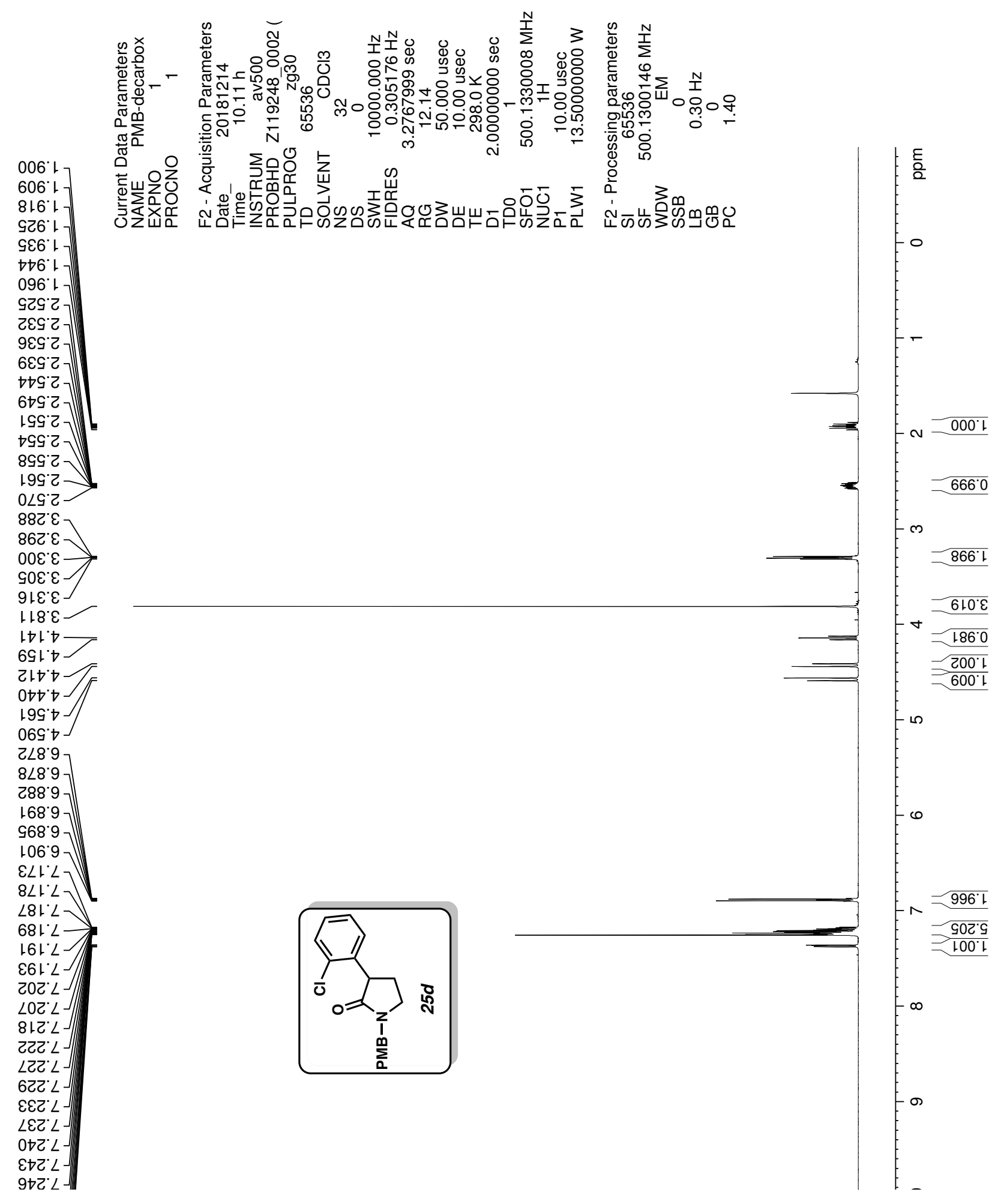




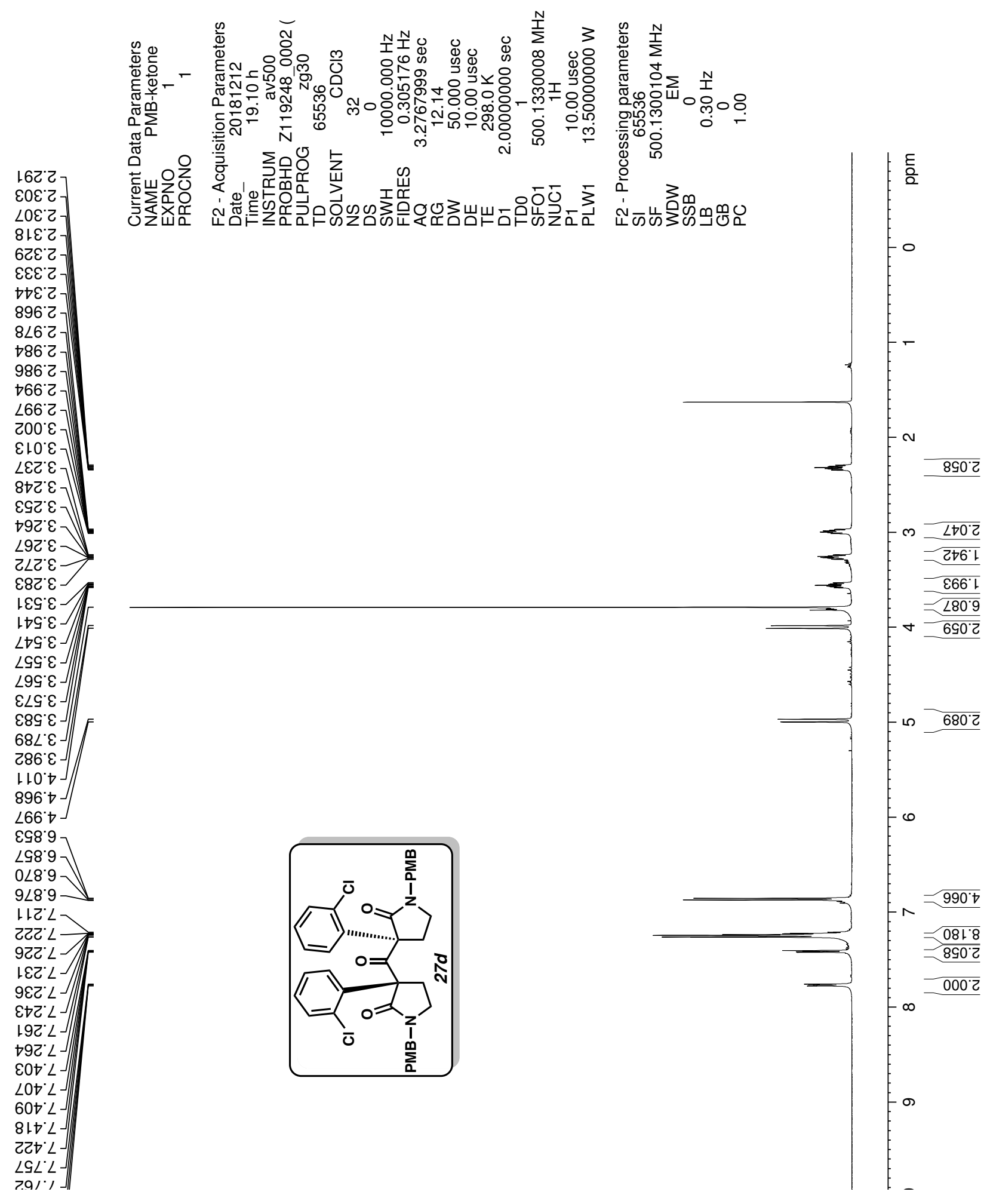




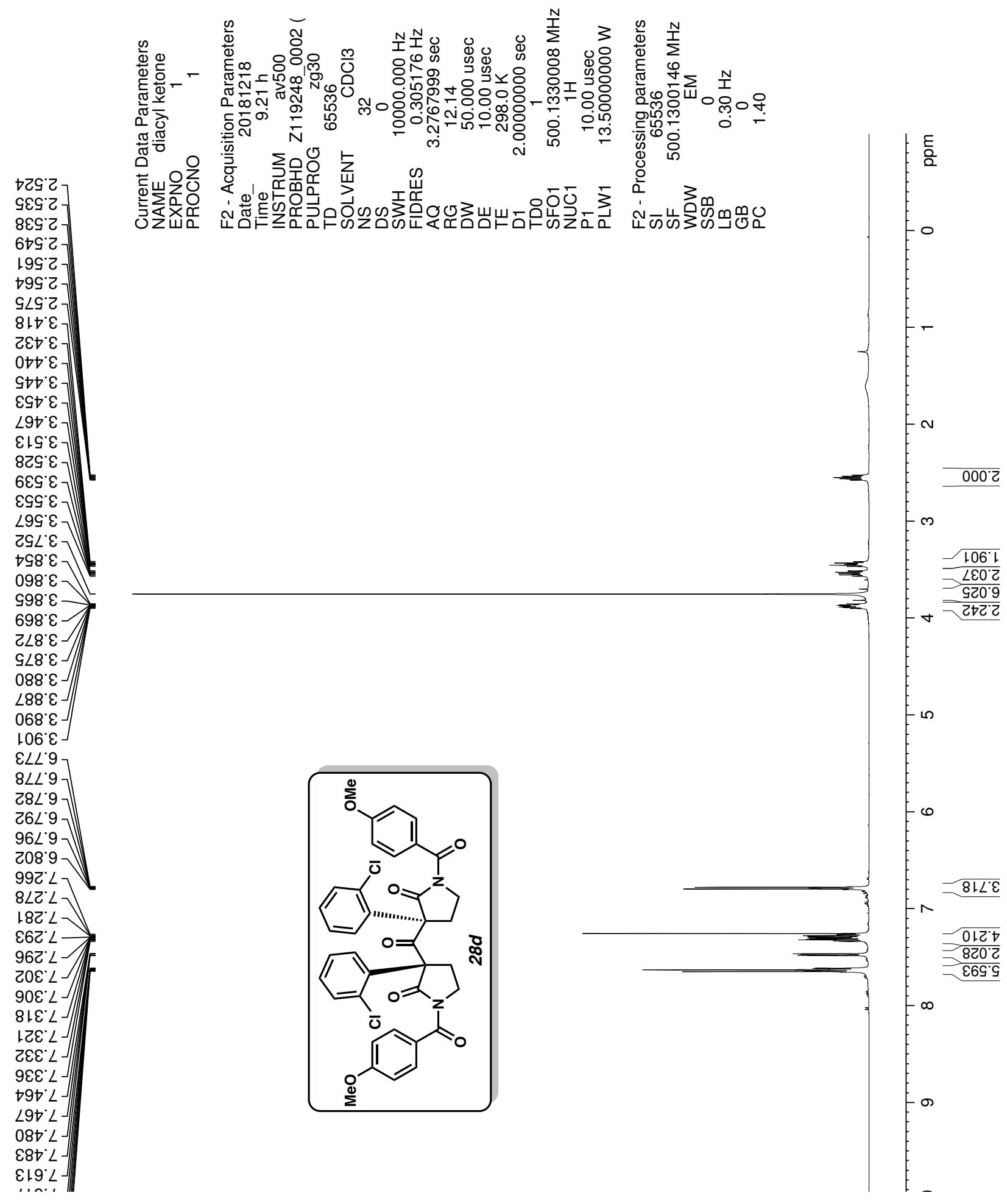




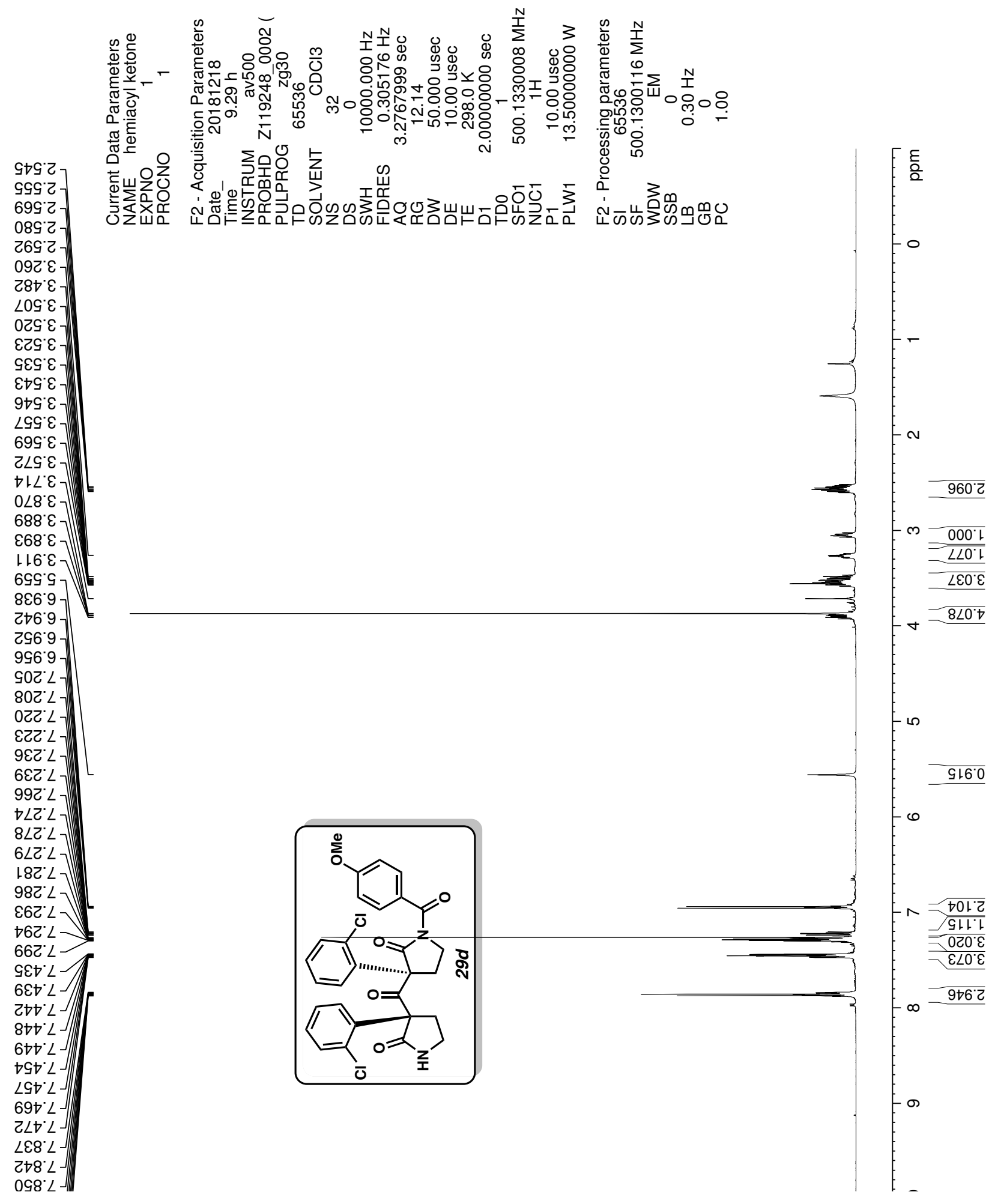



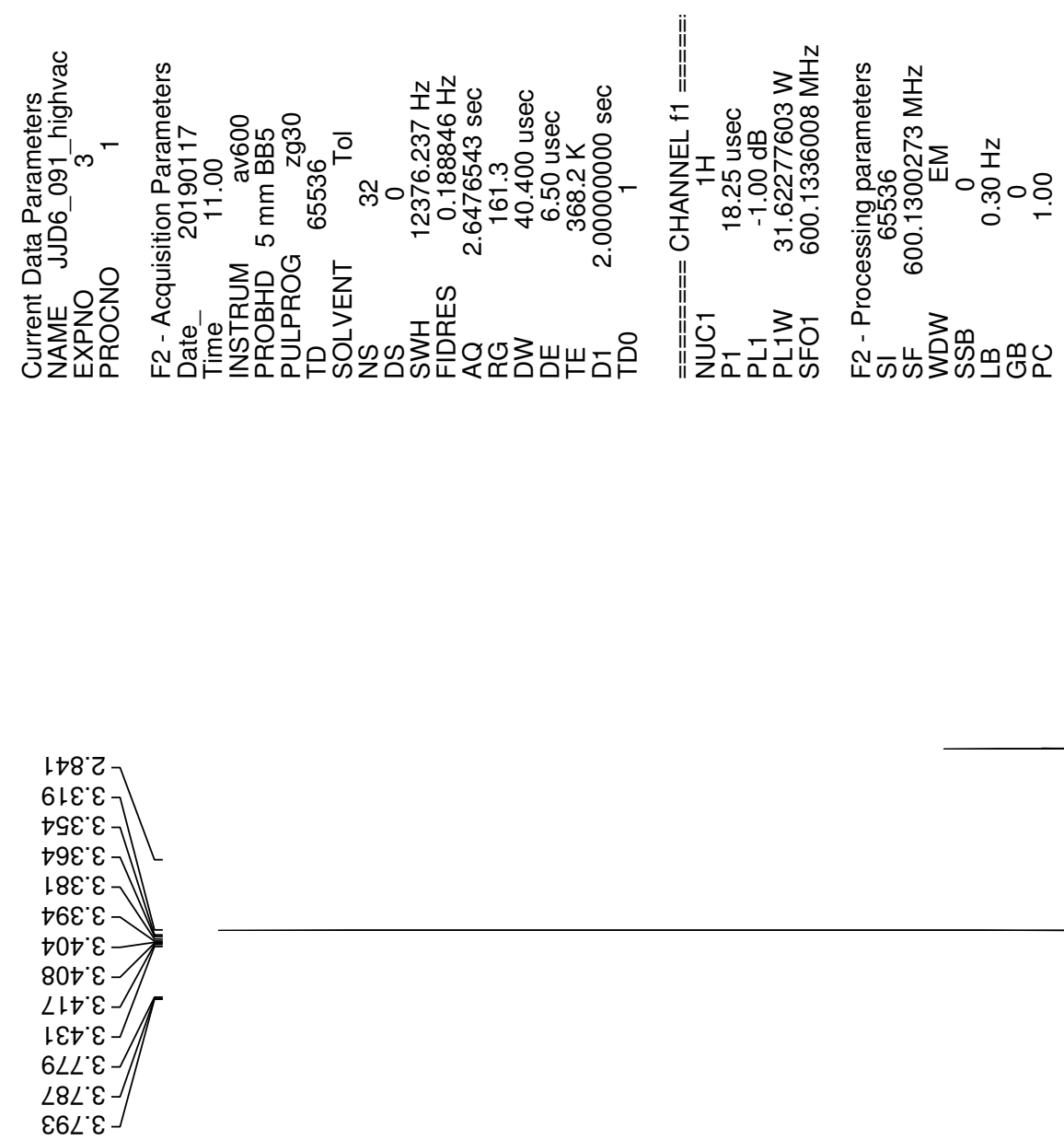

$\angle O L ' 9$

$0+\angle \cdot 9$

$\angle E L \cdot 9$

$0 S L ' 9$

टSL'9]

$\varepsilon 9 \angle \cdot 9$

$G L L \cdot 9$

$\angle L L ' 9$

$90 \mathrm{H}^{\circ} \mathrm{L}$

6012

6LIL

टटL'L

GटE: $L$

$\nabla \varepsilon \varepsilon^{\circ} L$

$\llcorner E L L L$

$G E L L L$

$\forall \forall L \cdot L$

$9+L \angle J$

ISLL

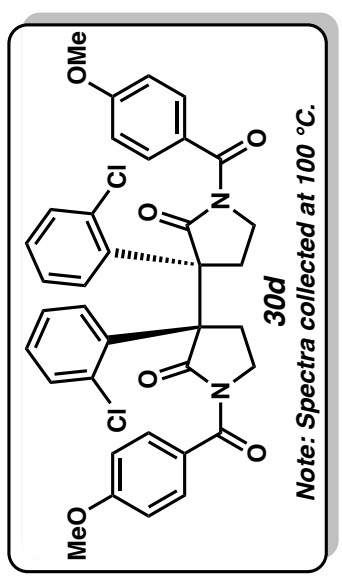



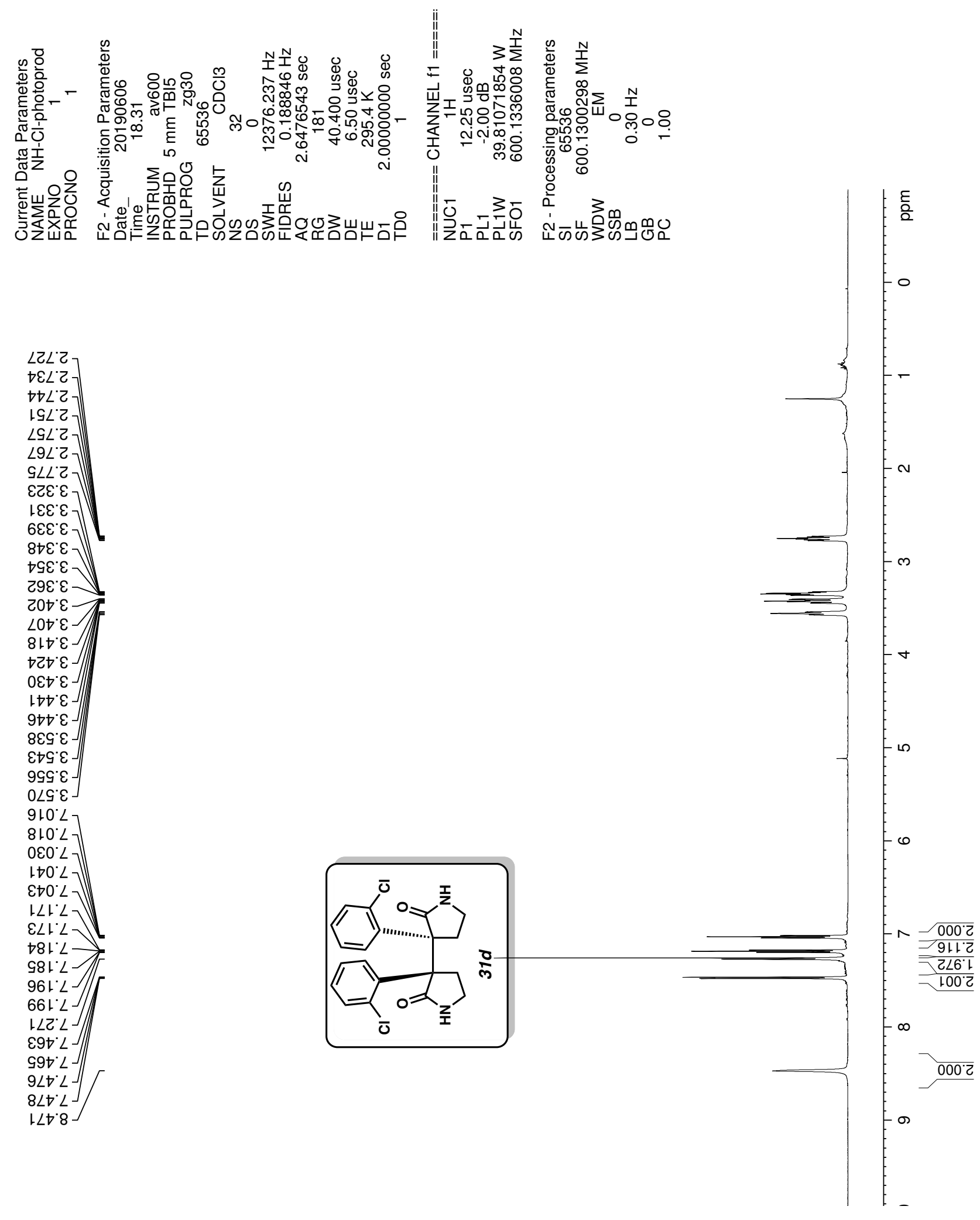


\section{${ }^{13}$ C NMR Spectra:}



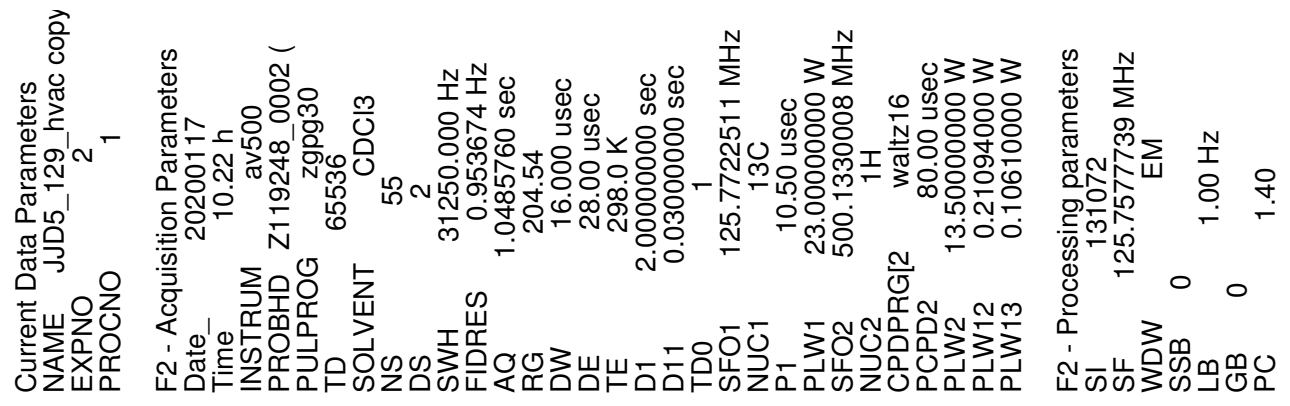

so"

$0 \nabla^{\circ} 92$

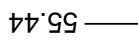

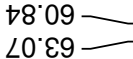

$\angle 0^{\circ} \varepsilon 9$

88. $\varepsilon$ เ

$\varepsilon 6^{\circ} \varepsilon เ \vdash \perp$

08.9เト -

เG'6เト

เ6.62 —

ट५'9ع -

$8 L^{\circ} 69+$

$8189+$

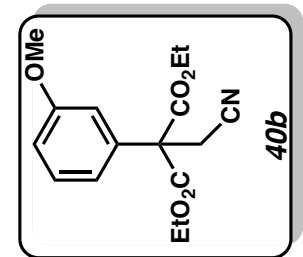


Dotson et al.: Discovery and Total Synthesis of Psychotriadine-Supporting Information - S97 

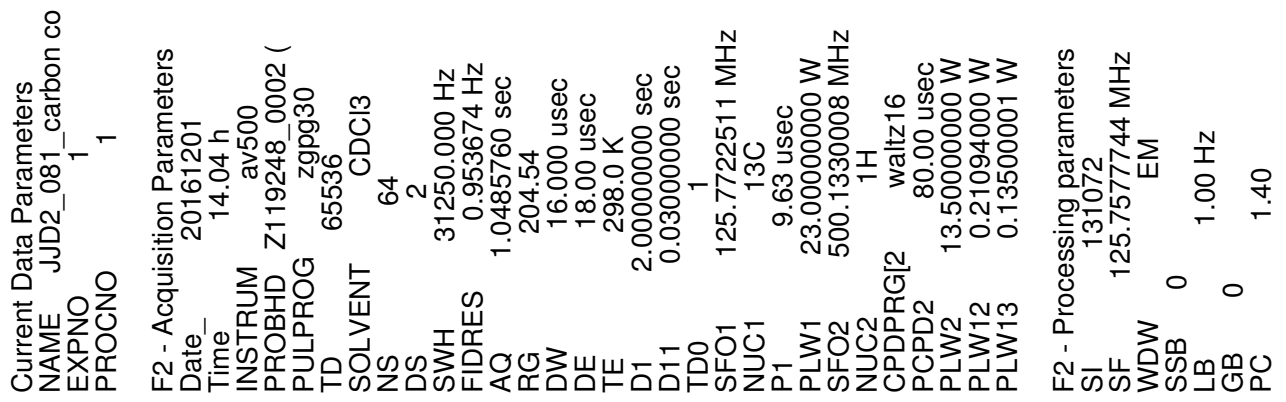

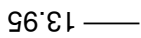

18. $\varepsilon 2-$

$62.19=$

$26.911-$

$6 G^{\circ} \angle Z L$

$0 \mathrm{Z}^{\circ} 0 \varepsilon \mathrm{L}$

$8 \mathrm{Z}^{\circ} 0 \varepsilon \mathrm{\varepsilon}$

$0 \nabla^{\circ} \vdash \varepsilon+$

$9+\varepsilon \varepsilon+$

$6 \mathcal{S}^{\prime} \varepsilon \varepsilon \mathrm{L}$

$9 \angle \angle 9 L$
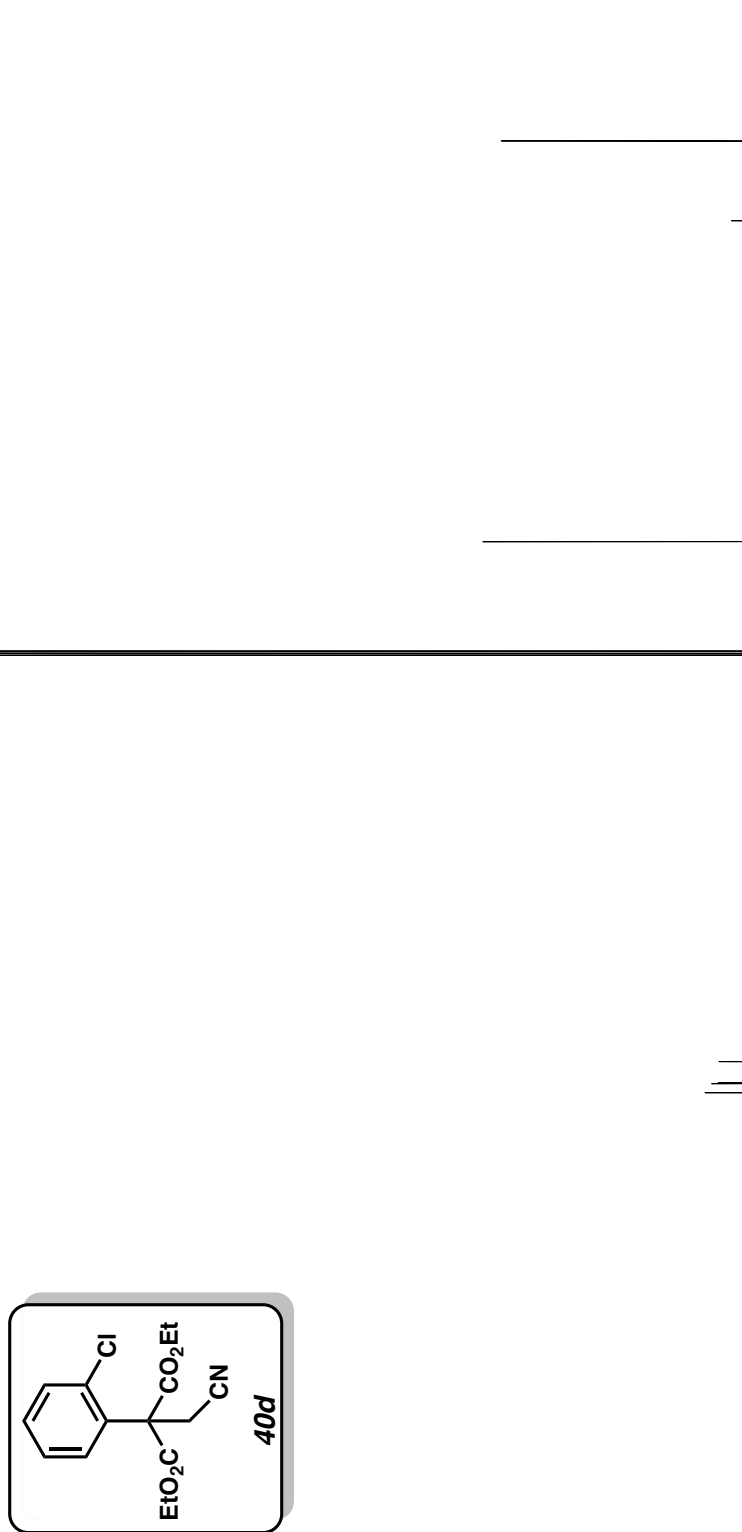


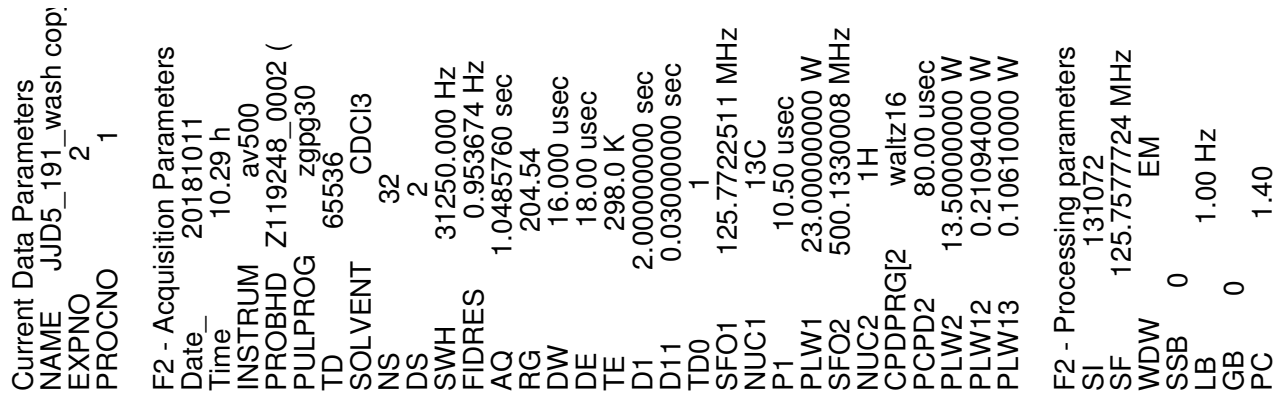

トトナトー

$86^{\circ} \varepsilon 2$

IS. $G S$

$\nabla L 6 S$

$6 L ' 29$

$\angle G^{*}$ เトレ

99

เE'เZト

88`てレ-

SL'8ZL -

$\left\llcorner\varepsilon^{\prime} 0 \varepsilon+\right.$

$8 \varepsilon^{\circ} 99 \vdash-$

89'891 -
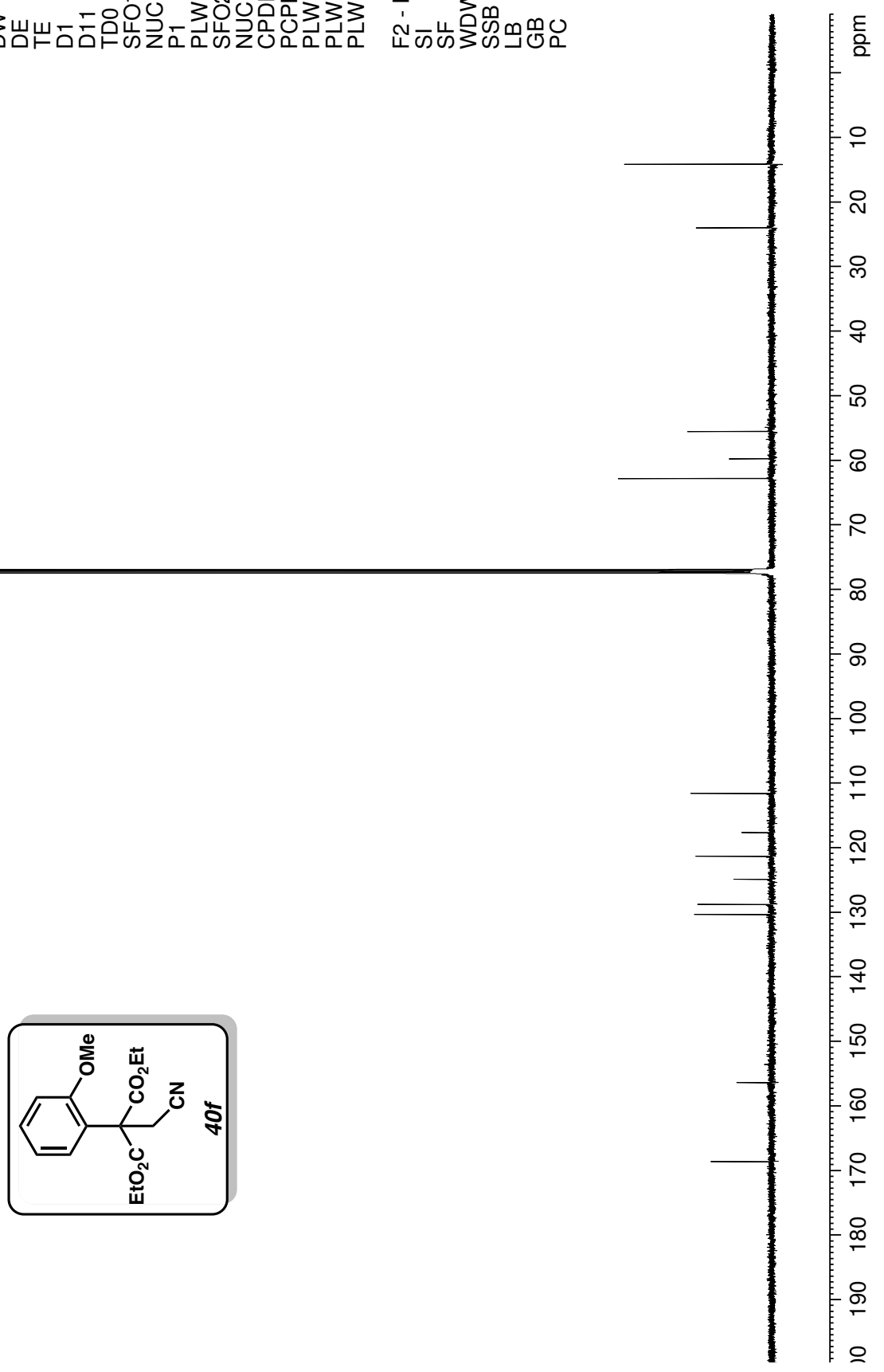

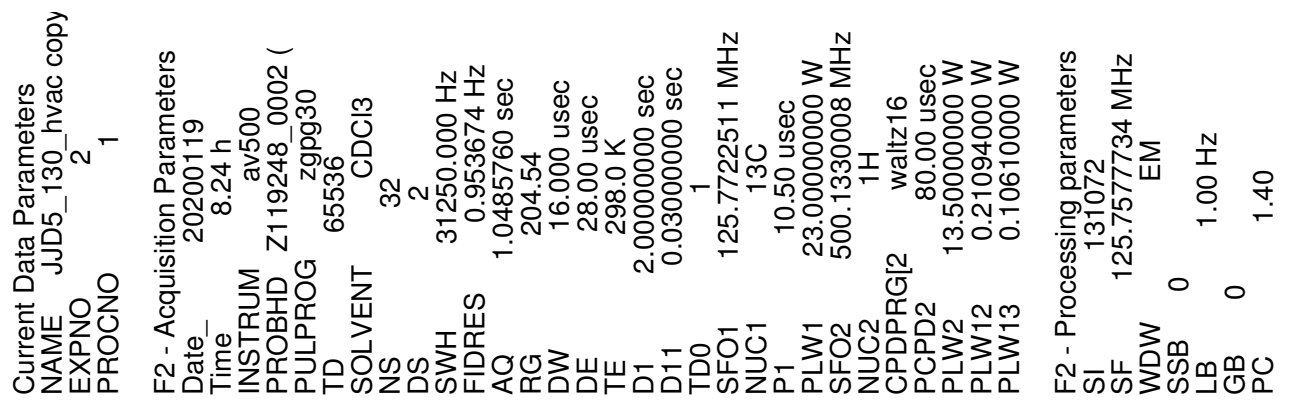

9เナレー

$\neg 6^{\circ} \nabla \varepsilon$

$6 \varepsilon^{\circ} 6 \varepsilon$

0799

18.69

$62^{\prime} 29-$

๑0レレ一

$99^{\circ} 6$ เト

$\varepsilon 9^{\circ} 62 \mathrm{~L}$

$8 \varepsilon^{\cdot} 6 \varepsilon\llcorner-$

LL'6G -

$09^{\circ} 0 \angle 1-$

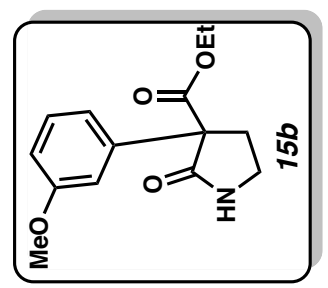

\section{mo}

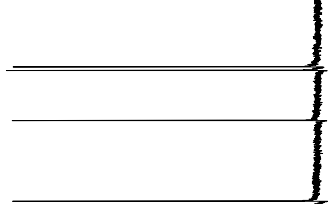




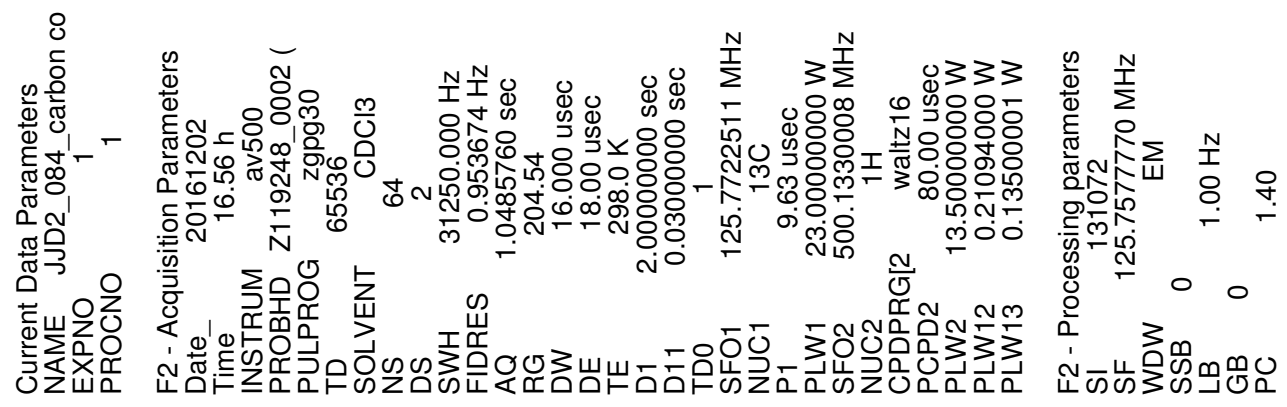

こ゚ナト —

$\varepsilon \mathcal{G}^{\circ} \varepsilon \varepsilon-$

$89^{\circ} 6 \varepsilon$

$\varepsilon t^{\circ} \cdot 9$
$89 \cdot 29=$

乙Z' $\angle Z \vdash$

$99 \cdot 821$

$\varepsilon 6.8 \mathrm{~L}$ -

$0<\cdot 0 \varepsilon \downarrow$

ट6. $\varepsilon \varepsilon+$

$\angle L \cdot \angle E L$

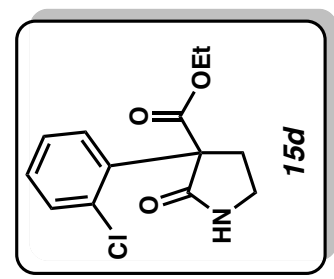




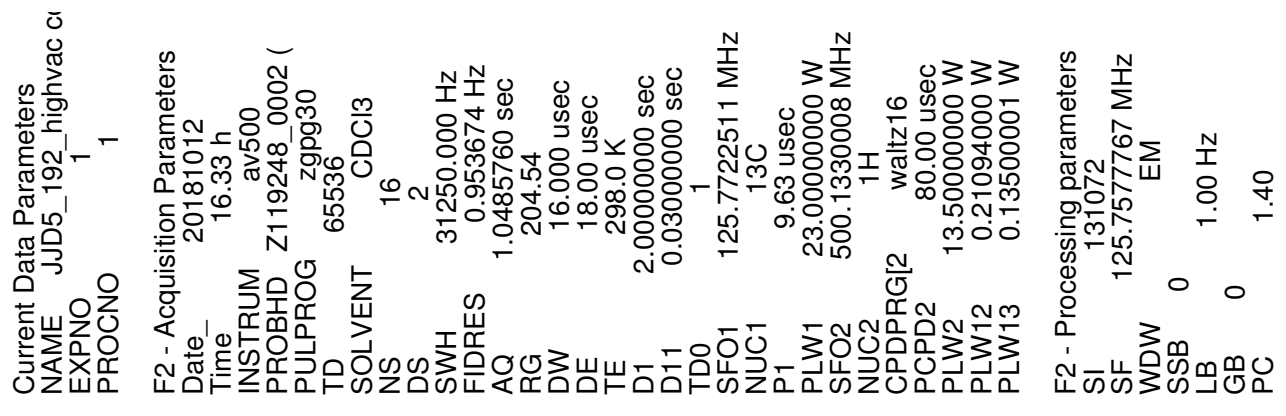

6ト・・レー

เ9' $\varepsilon \varepsilon$

$0 L^{\circ} 6 \varepsilon$

8Z'99

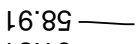

$18 \cdot 19$

E6.0トト -

$98 \cdot 02$ -

69. 2 टZ

ट8.8टा

$88^{\circ} 991-$

S0: $\angle L-$

$966^{\circ} \bullet \angle L-$

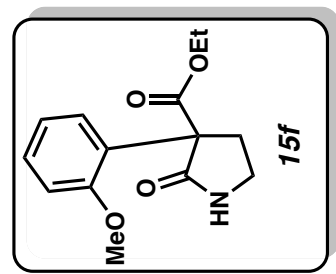



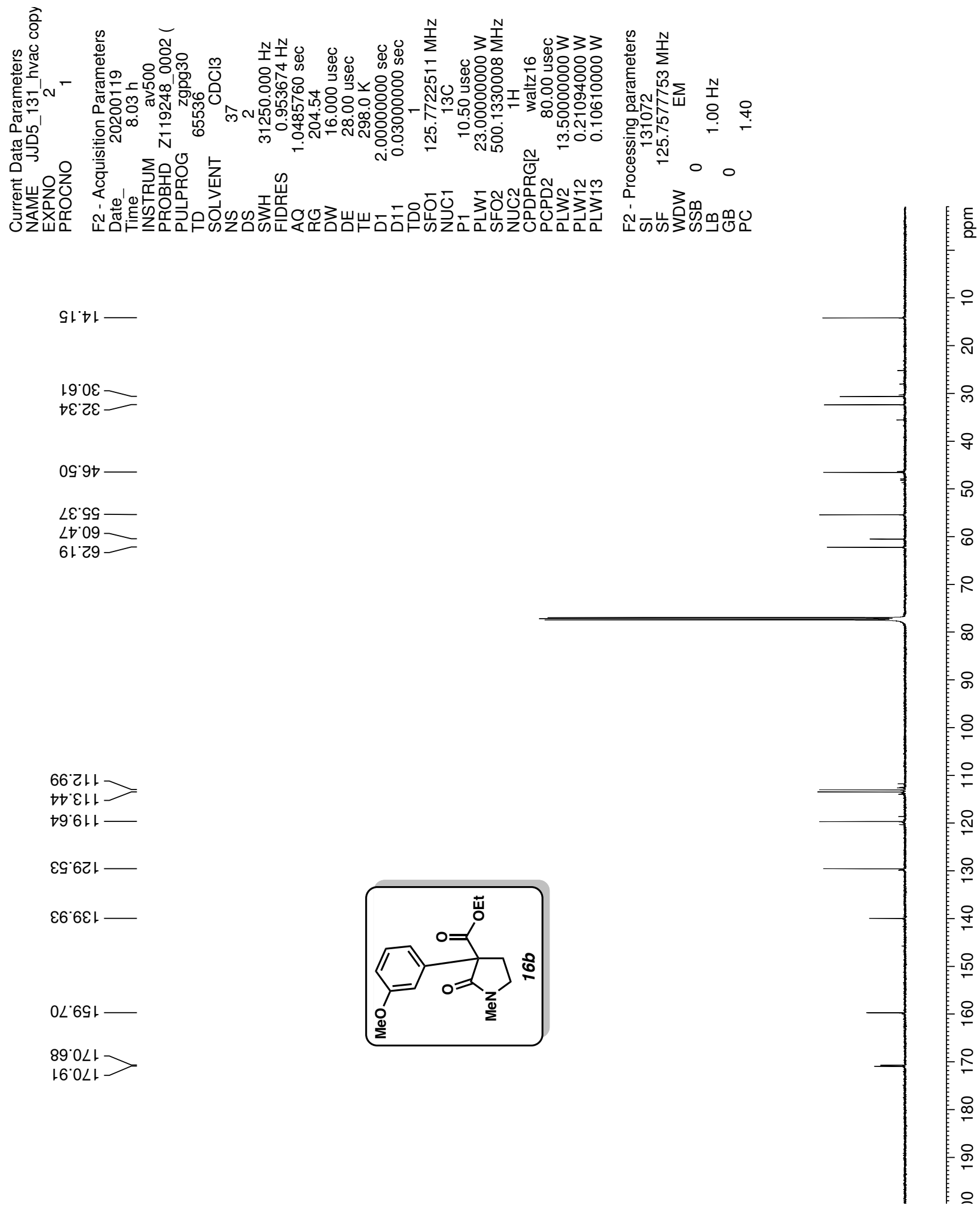


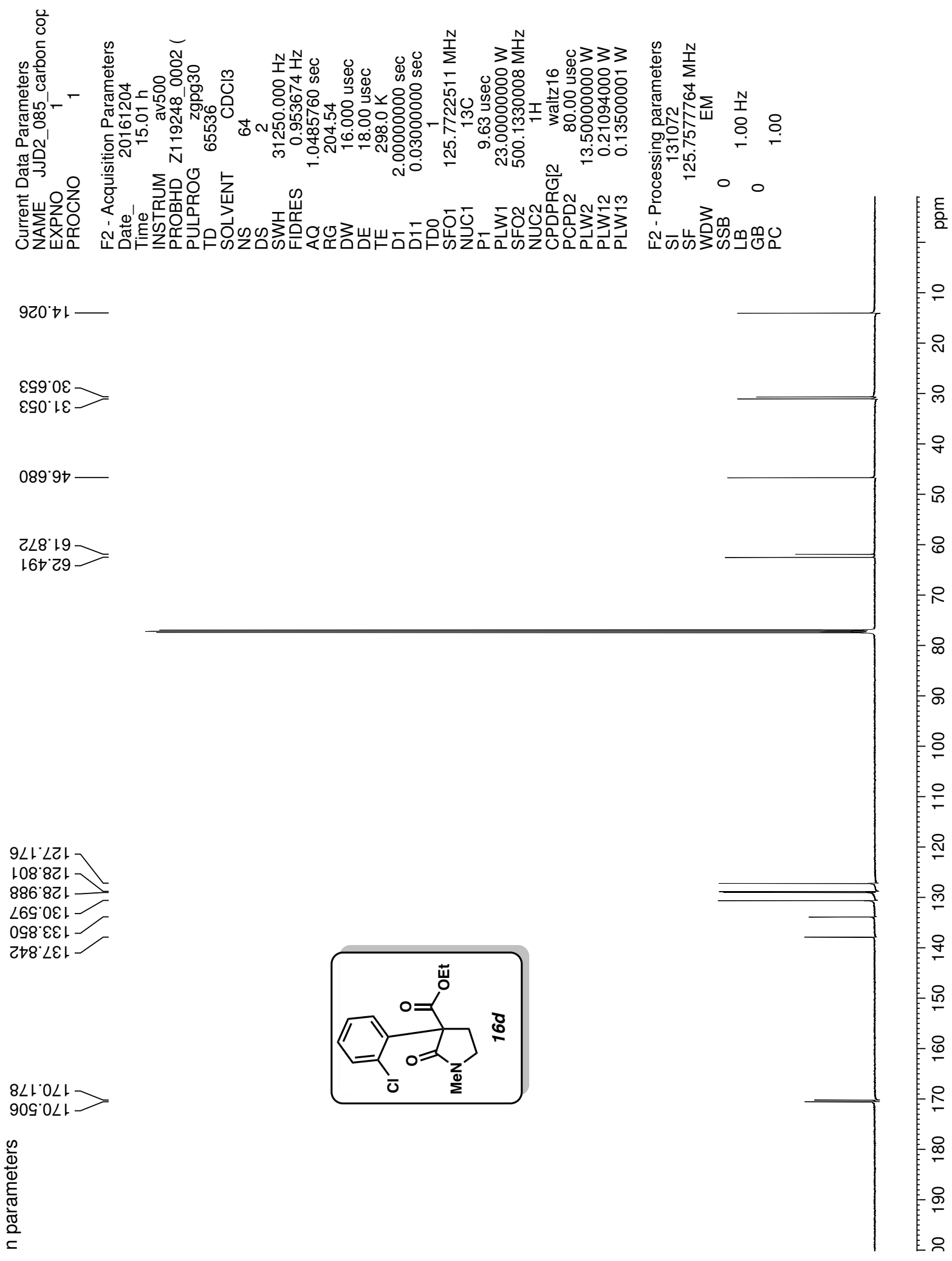




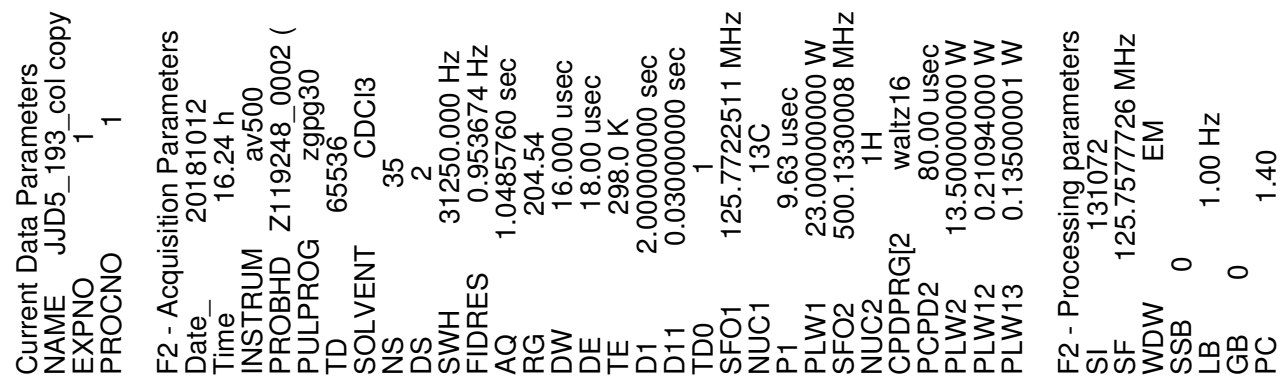

ย己゙ャト —

$69^{\circ} 0 \varepsilon$

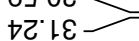

$78 \cdot 9 \triangleright$

$0 \varepsilon \cdot 99-$

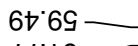

$\angle L ' 19 \longrightarrow$

$68^{\circ}$ ํトレ—

$68 \cdot 02$ -

$1 \angle L C L$
$\varepsilon \angle{ }^{\circ} 8 L 1>$

$\angle 6.821$
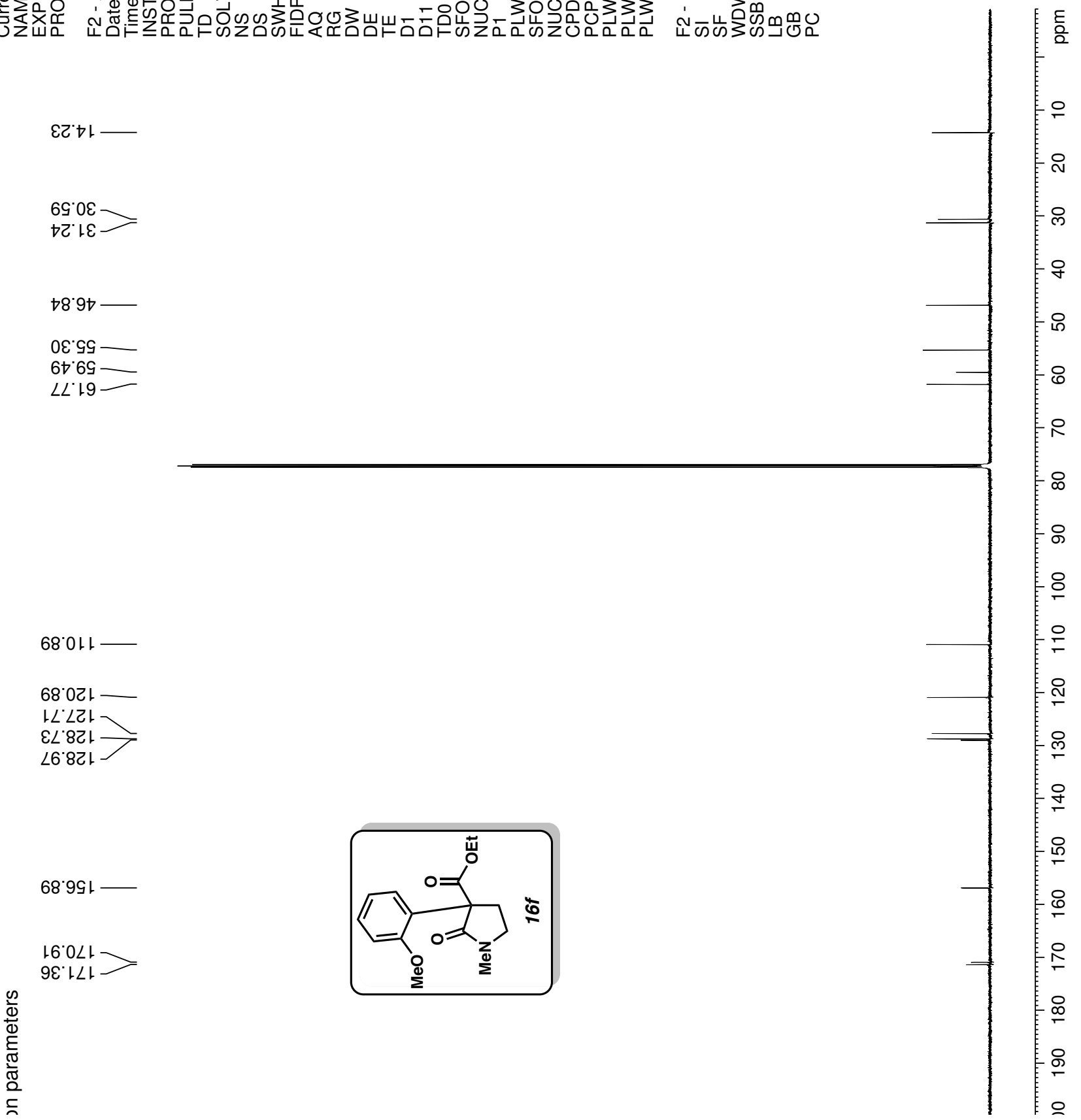

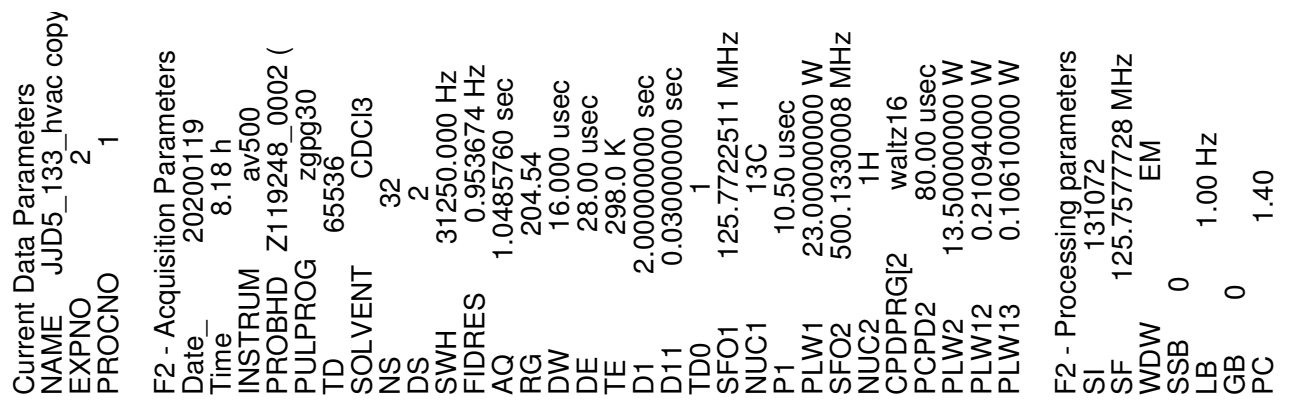

10.82

$9 Z^{\circ} 0 \varepsilon-$

$\angle 8 \cdot \angle t$

S. $8 \mathrm{t}>$

$9 \varepsilon \cdot \varsigma 9-$

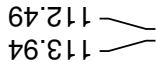

6己'0乙レ -

98'6己เ -

89เレトー

96.69ト

$68^{\circ} \bullet \angle L-$

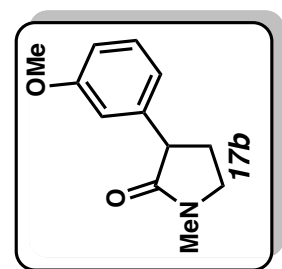




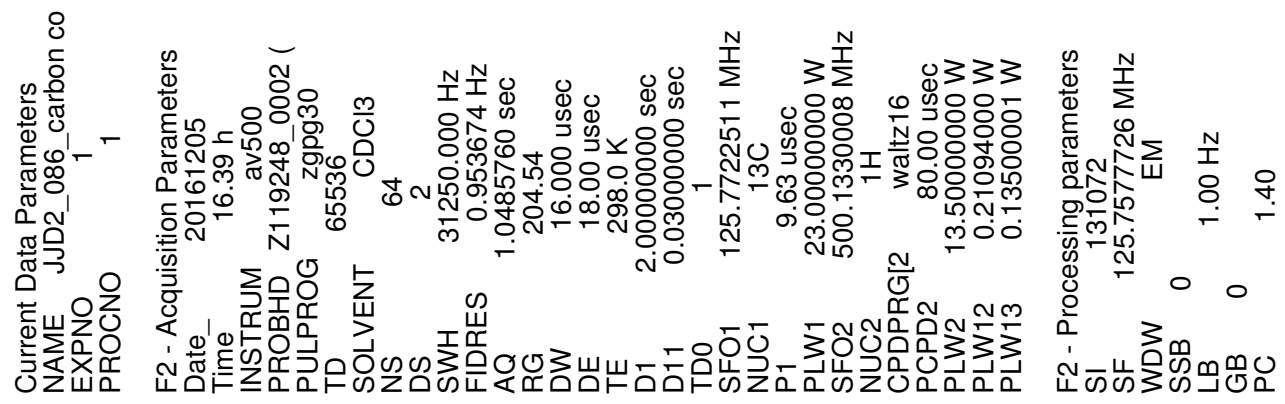

$H^{\circ} L Z-$

¿हं $0 \varepsilon-$

$80.9 t=$

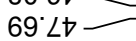

$t^{\circ} L C L$

टt'8टt

$97 \cdot 621$

18.621

เ゙๋ยト

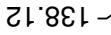
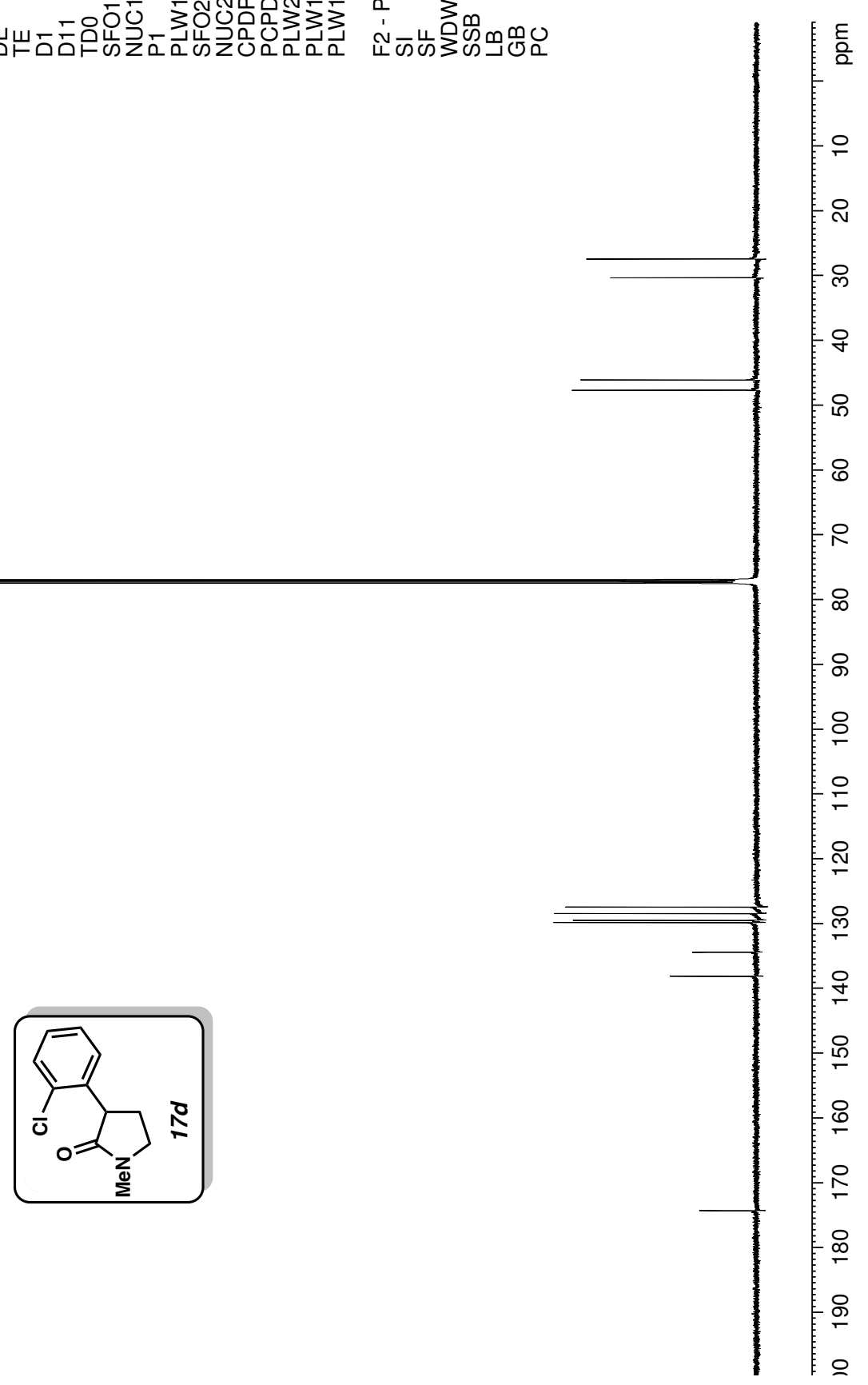

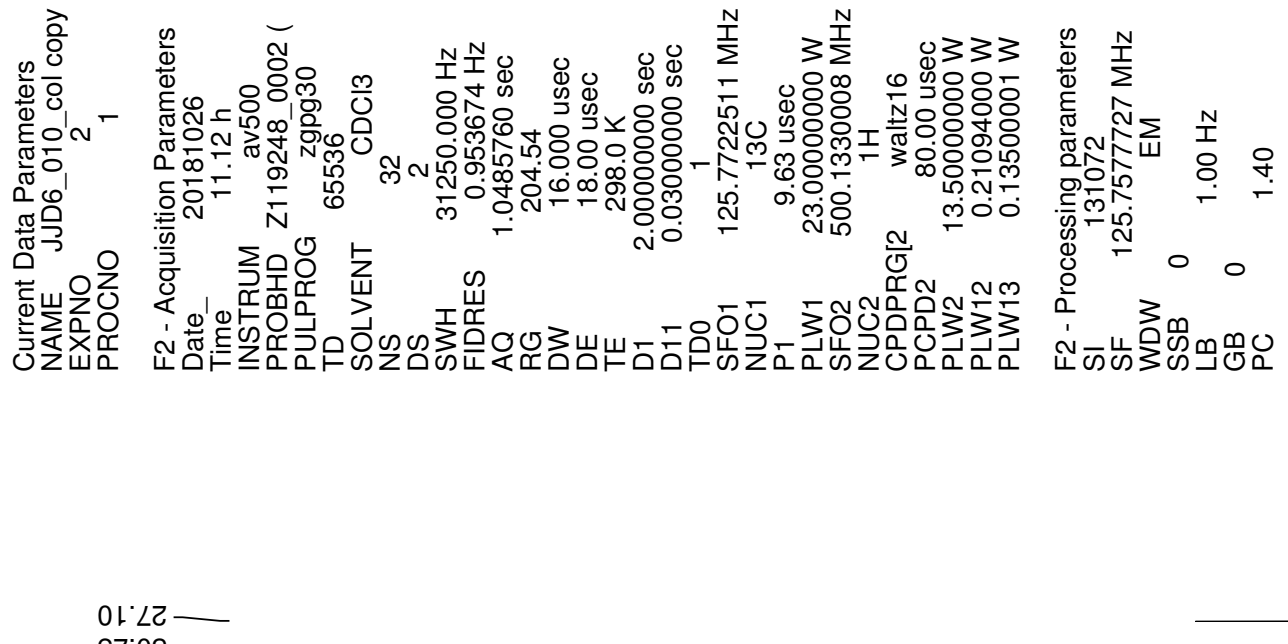

$\mathrm{G} \cdot 0 \varepsilon-$

$0 L \cdot \varepsilon t-$

$70^{\circ} 8 \mathrm{r}$

$69 \cdot 99$

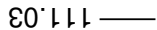

96.021

$1 \varepsilon^{\circ} 82 t$

$\nabla 6.821$

$\angle \nabla^{\circ} 62$ เ

ZS'LSL -

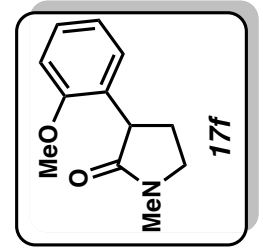



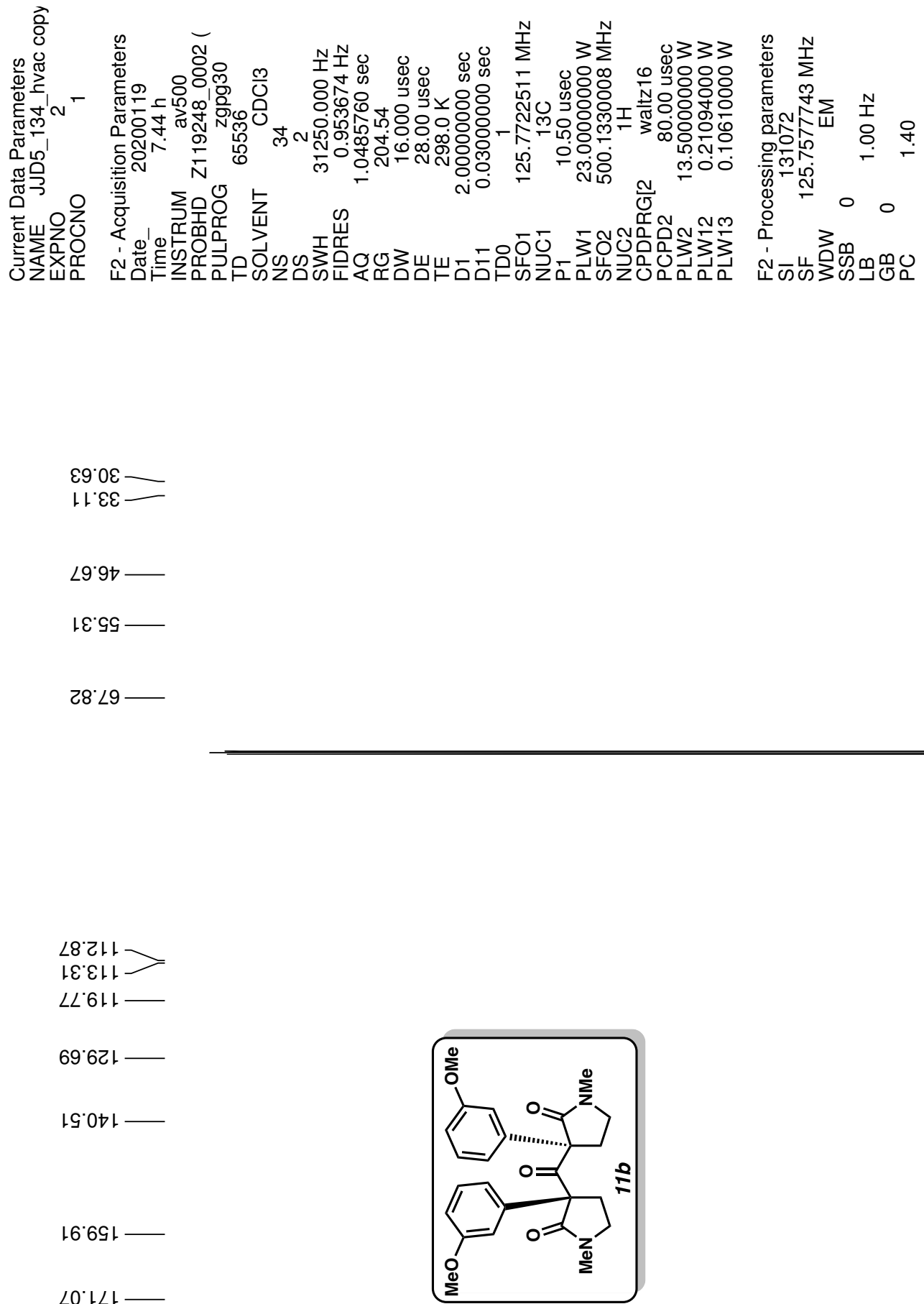

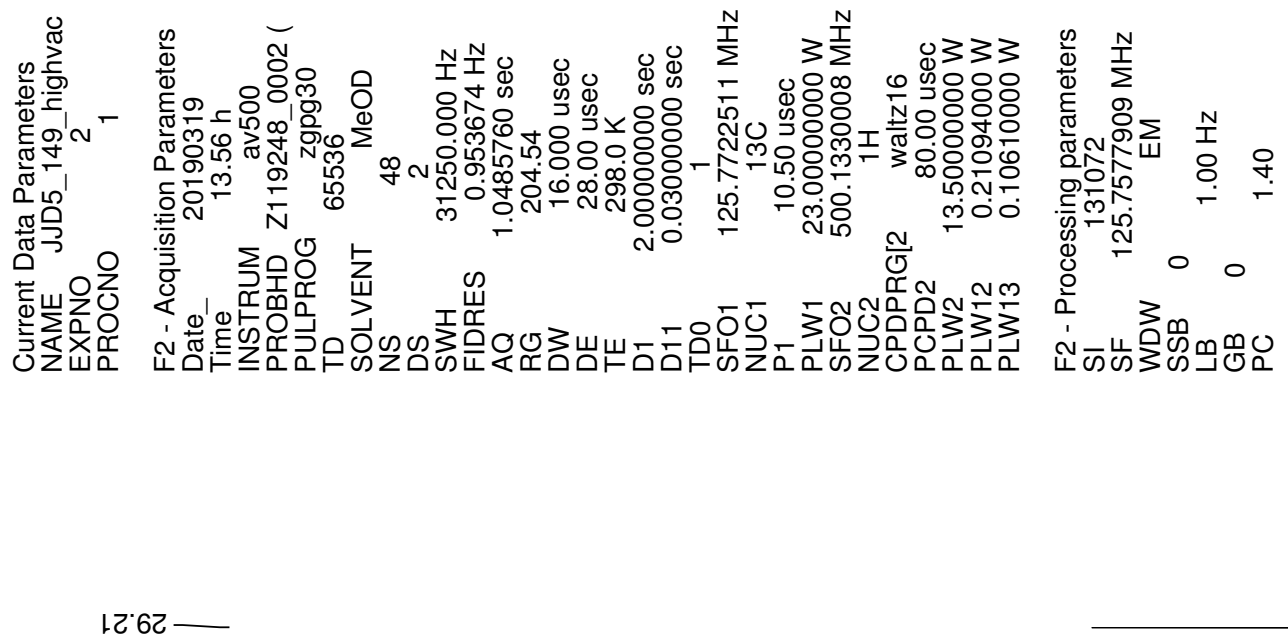

ง8: ¿E-

$6+9 t$

26.29

66.나

90ㄴ. >

06 나 -

งะ 62 -

$66.6 \varepsilon$ -

$6 T^{\circ} \angle S+$

$\varepsilon L ' L L+$
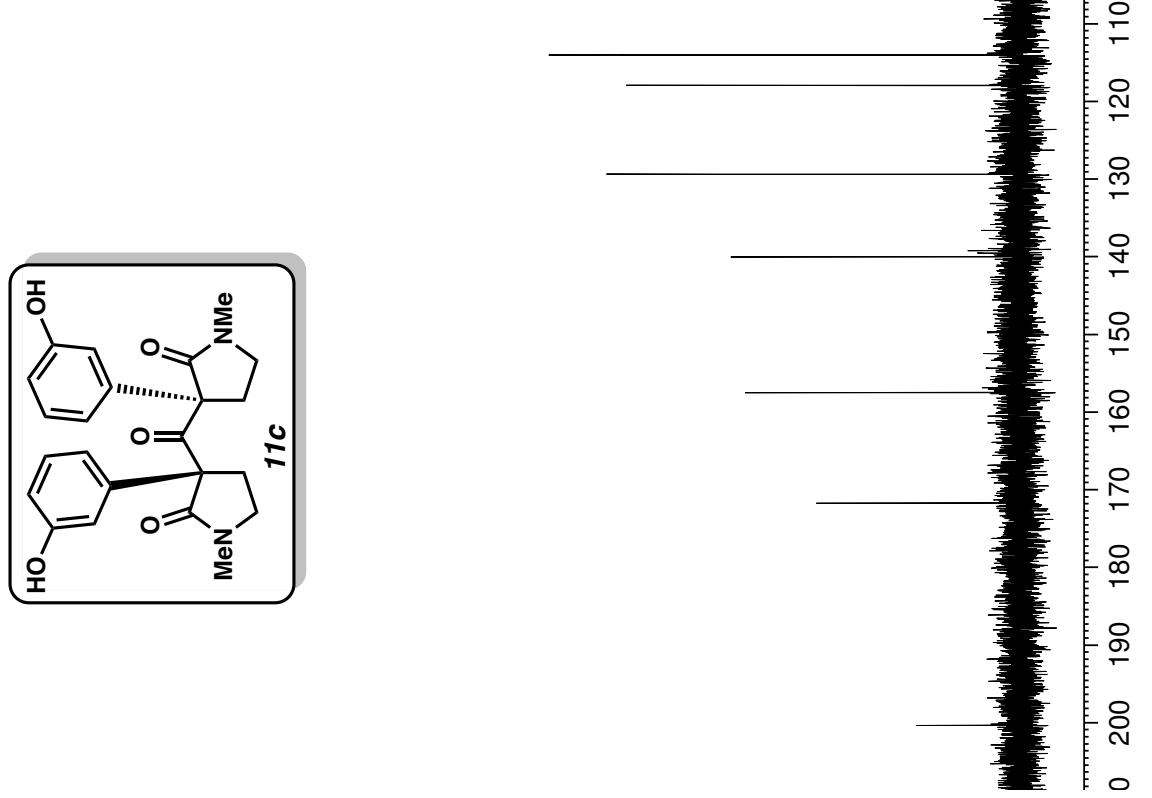

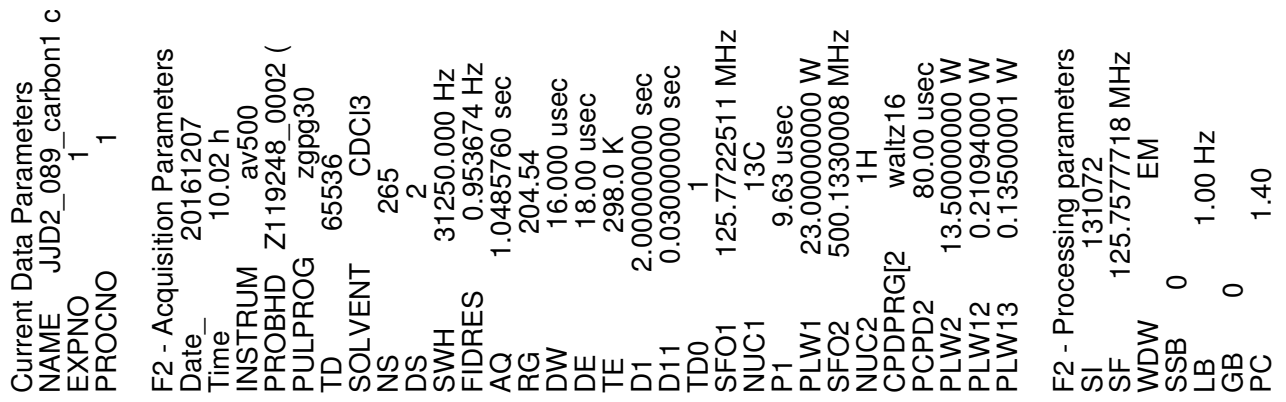

$\downarrow 8 \cdot 0 \varepsilon$

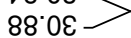

$\angle 8 \cdot 9 t-$

$\varepsilon \varepsilon^{*} 69$

$9 L \cdot 92+$

ट0.6टा

$69^{\circ} 0 \varepsilon \mathrm{L}$

ง8'เยเ

$20^{\circ} \nabla \varepsilon+$
$6 \varepsilon^{\circ} \angle \varepsilon+$

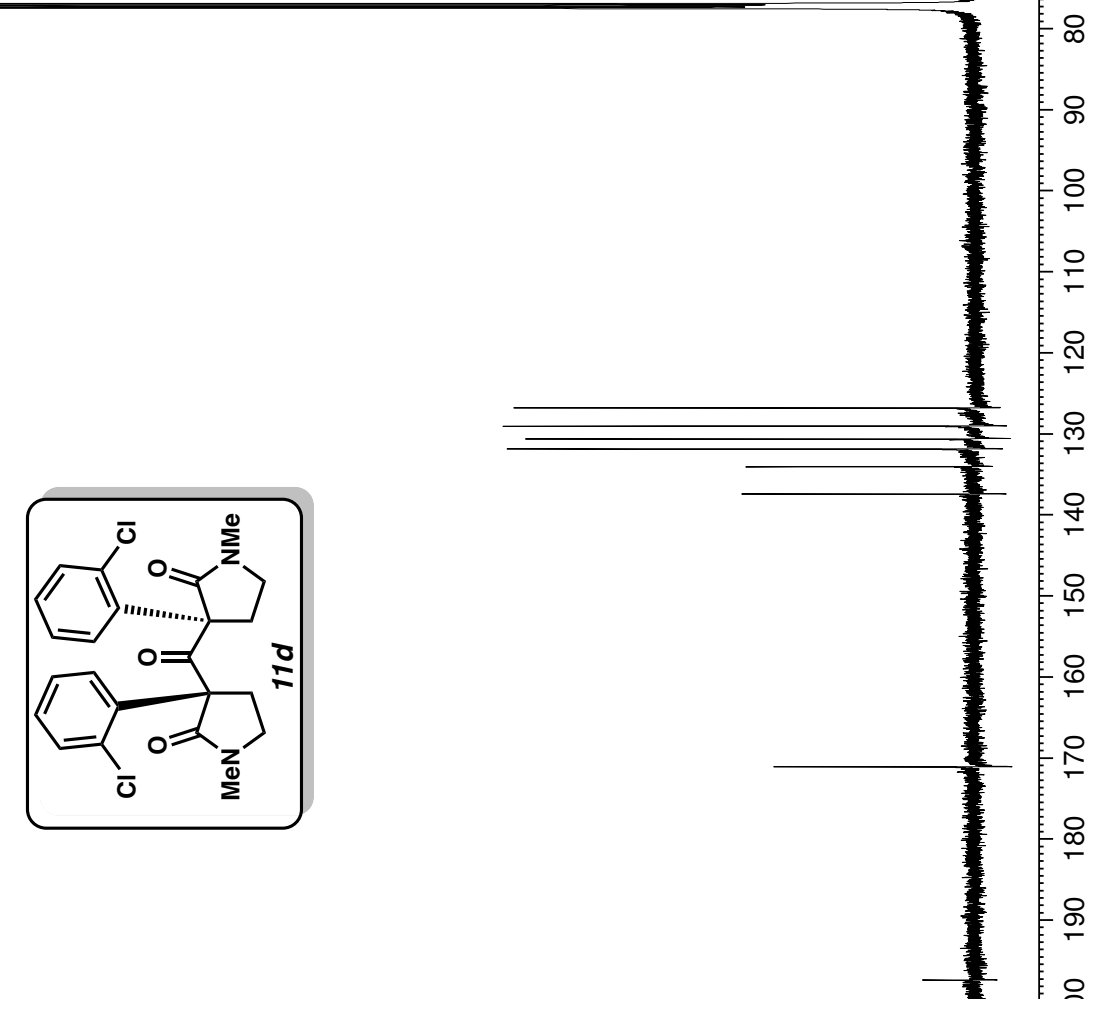




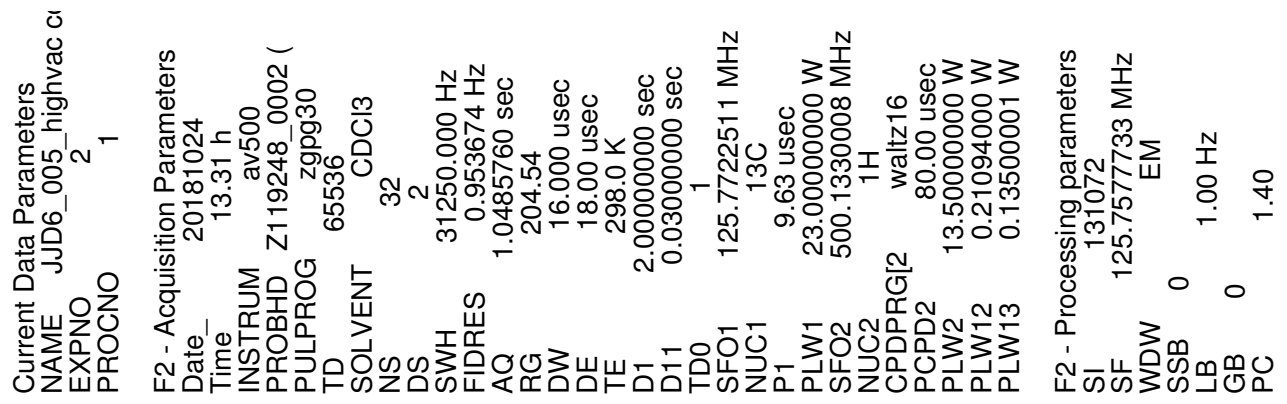

$69^{\circ} 0 \varepsilon$

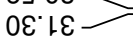

$6+\angle t \longrightarrow$

$0 t \subseteq 9$

$\angle 8^{\circ} \angle 9$

86・レトー

เナ゚0てト

98.821

$\angle L^{\circ} 62 \mathrm{~L}$

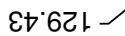

$00^{\circ} \angle S+$

$90^{\circ} 2 \angle 1-$

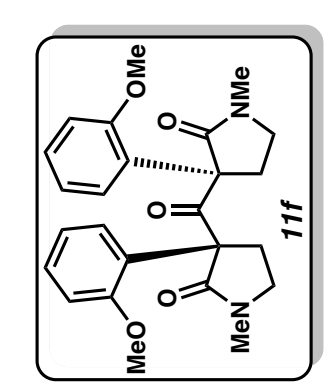



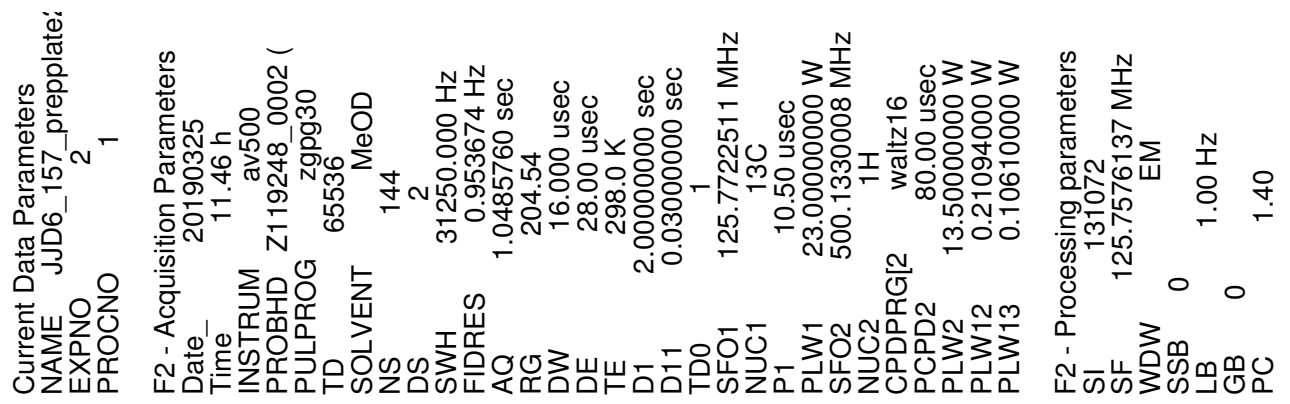

$82 \cdot 0 \varepsilon$

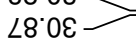

$t \angle \cdot 9 t$

ZI'LS-
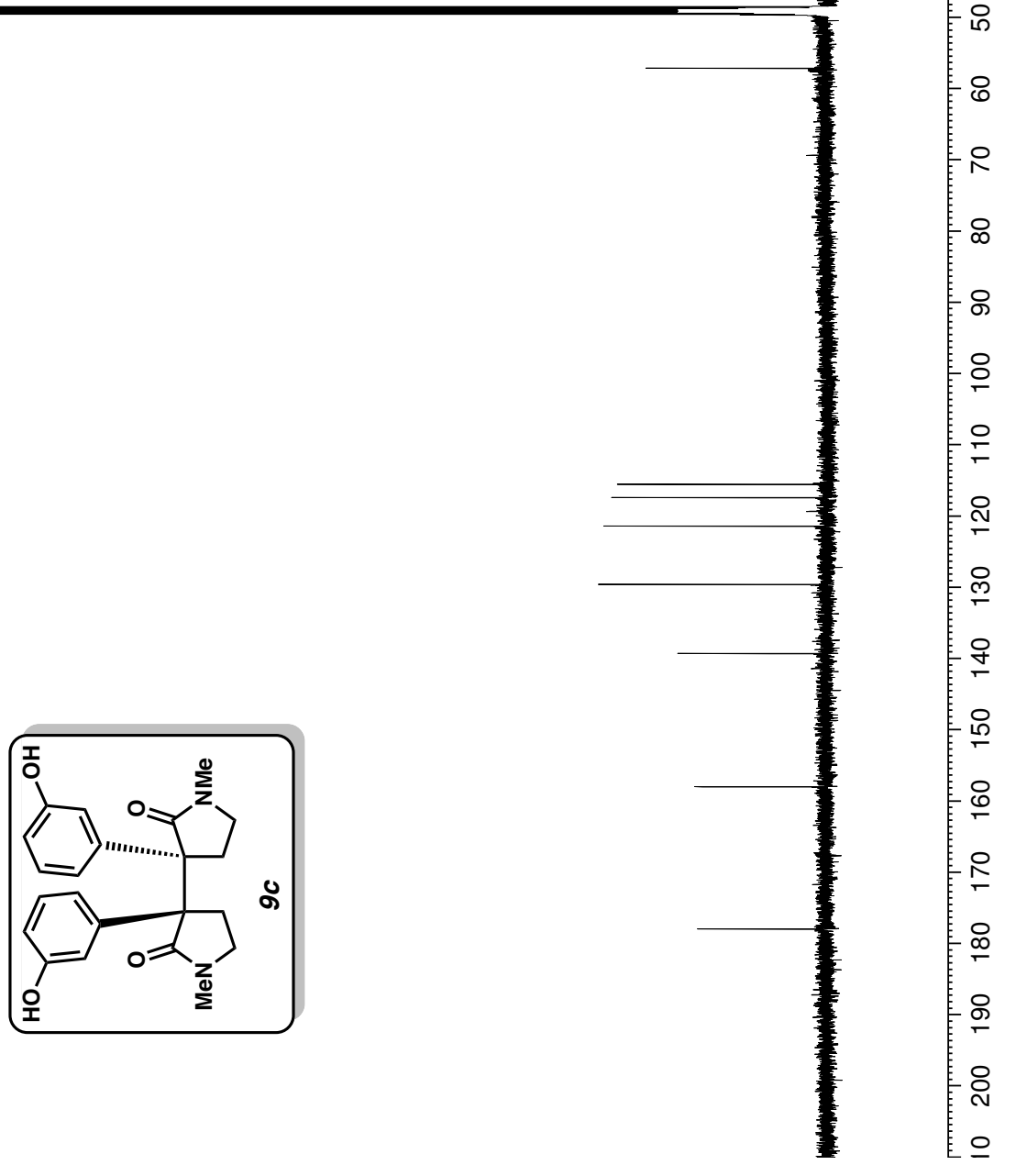


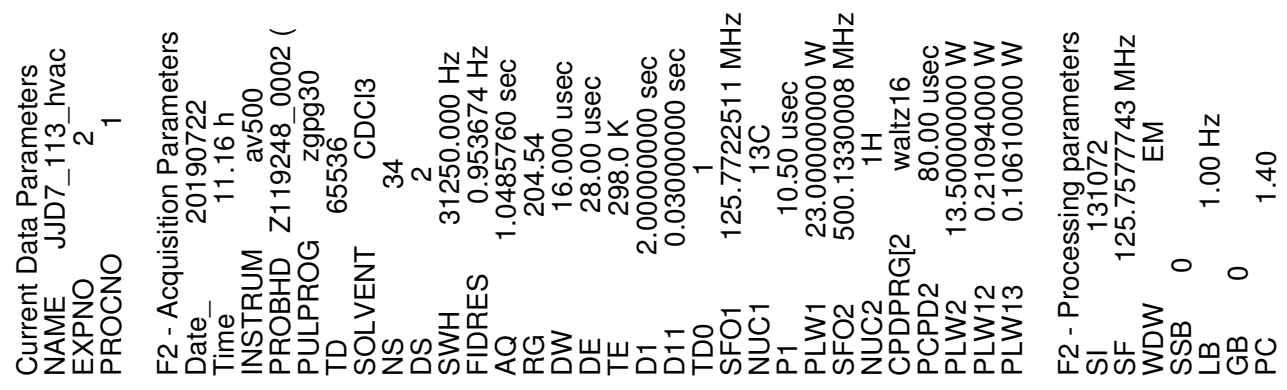

$8 \varepsilon^{\circ} 0 \varepsilon$

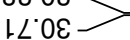

เレ'8t

$8 \varepsilon^{\circ} 69-$

ย6"

$6 เ \cdot 82+>$

Gट'ZEL

$\downarrow \varepsilon^{\circ} \nabla \varepsilon+$

$69^{\circ} \nabla \varepsilon+$

เトO゚ト

ฤฑ์EL -

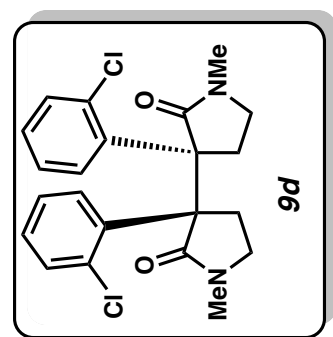




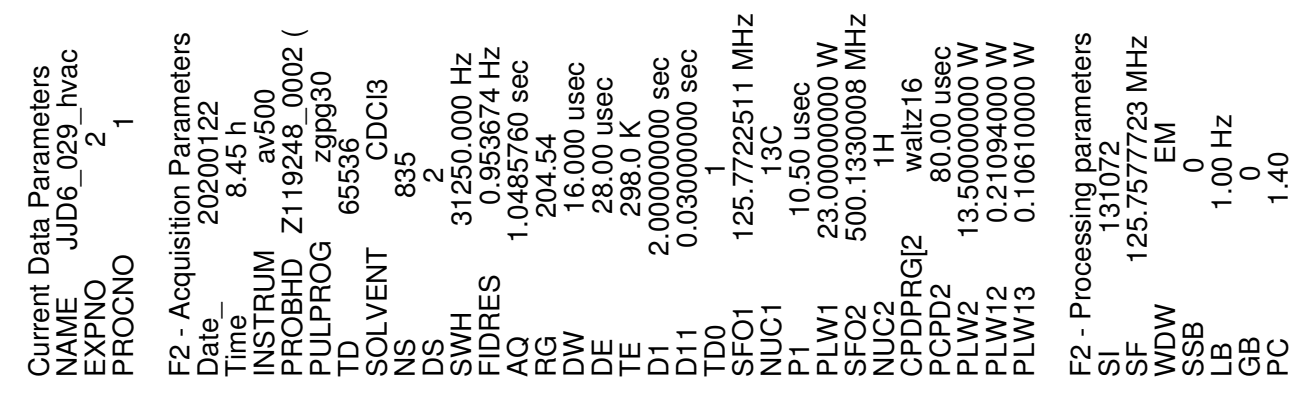

$9 L^{\circ} 0 \varepsilon-$

$\mapsto 0^{\circ} \bullet \bullet-$

$\nabla S^{\circ} \mathrm{S}$

$82 \cdot 69$

$9 \varepsilon \cdot \varepsilon เ$

५8.9ट।

$9 \varepsilon^{\circ} \angle Z L$

8t.8टt

Gเ'62 -

ट० टहा

५8' $\downarrow \varepsilon\llcorner$

५ट ๕9। -

69.69 -

S8: $L$ -

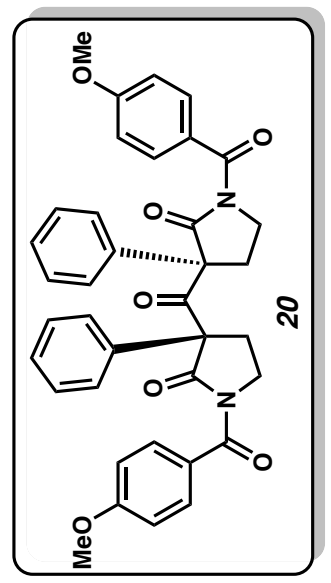



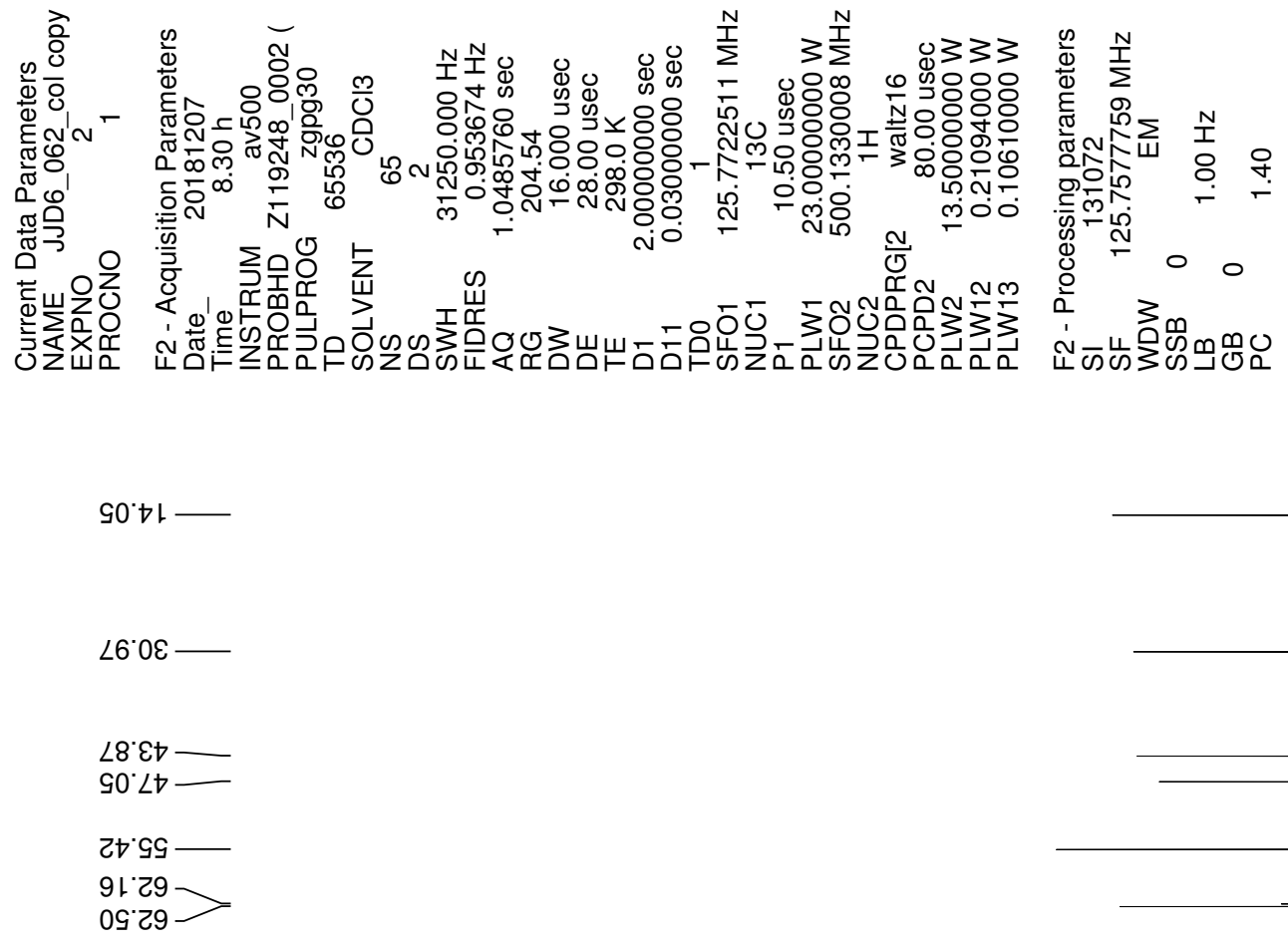

くでャレー †เட己レ $86^{\circ}$ L乙レ เ8.8ट

26.8己เ

GL'6己ᄂ

†9०0ह

$88^{\circ} \varepsilon \varepsilon\llcorner$

$\angle 9^{\circ} \angle E L$

LE'6Sト

SLOLL $>$

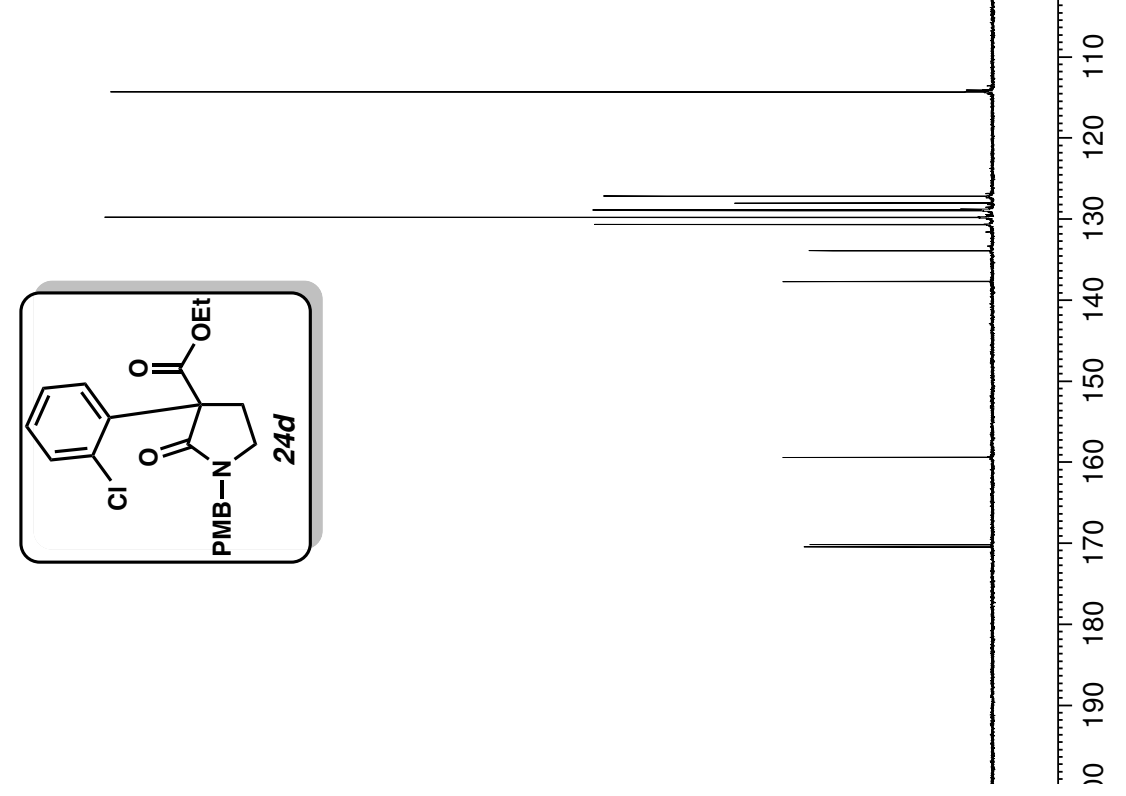

$t t^{\circ} 0<1>$ 


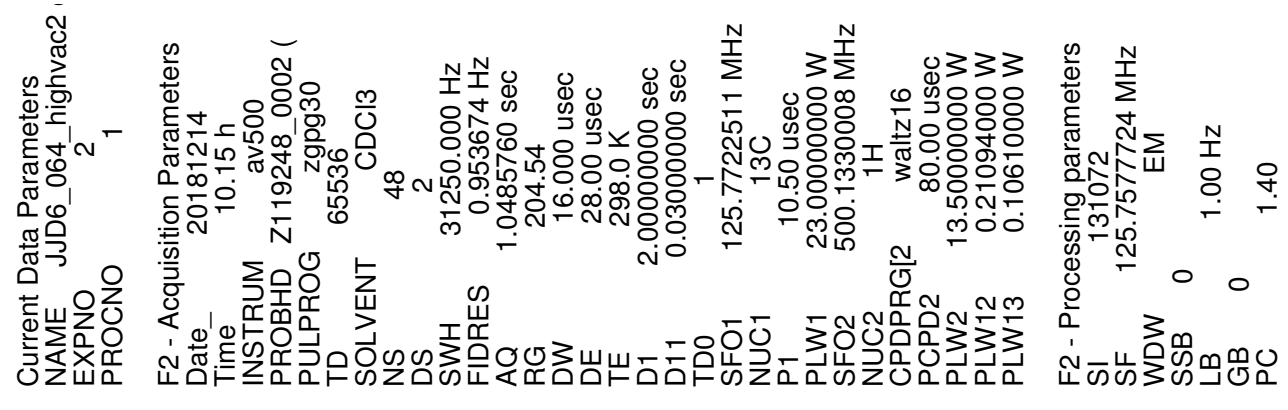

$6 乙\llcorner 乙-$

$\varepsilon L^{\prime} t \nabla$

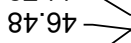

$89^{\circ} 9 t$

St' 9 -

カでャトレ

$0 \nabla^{\circ} \angle Z L$

St.82

$\angle 9{ }^{\circ} 821$

$99^{\circ} 6 \mathrm{LL}$

ट8.6己1-

98.621

$8 \varepsilon^{\circ} \dagger \varepsilon\llcorner$

ट००८हเ

0ะ'69เ -

$66^{\circ} \varepsilon \angle L$
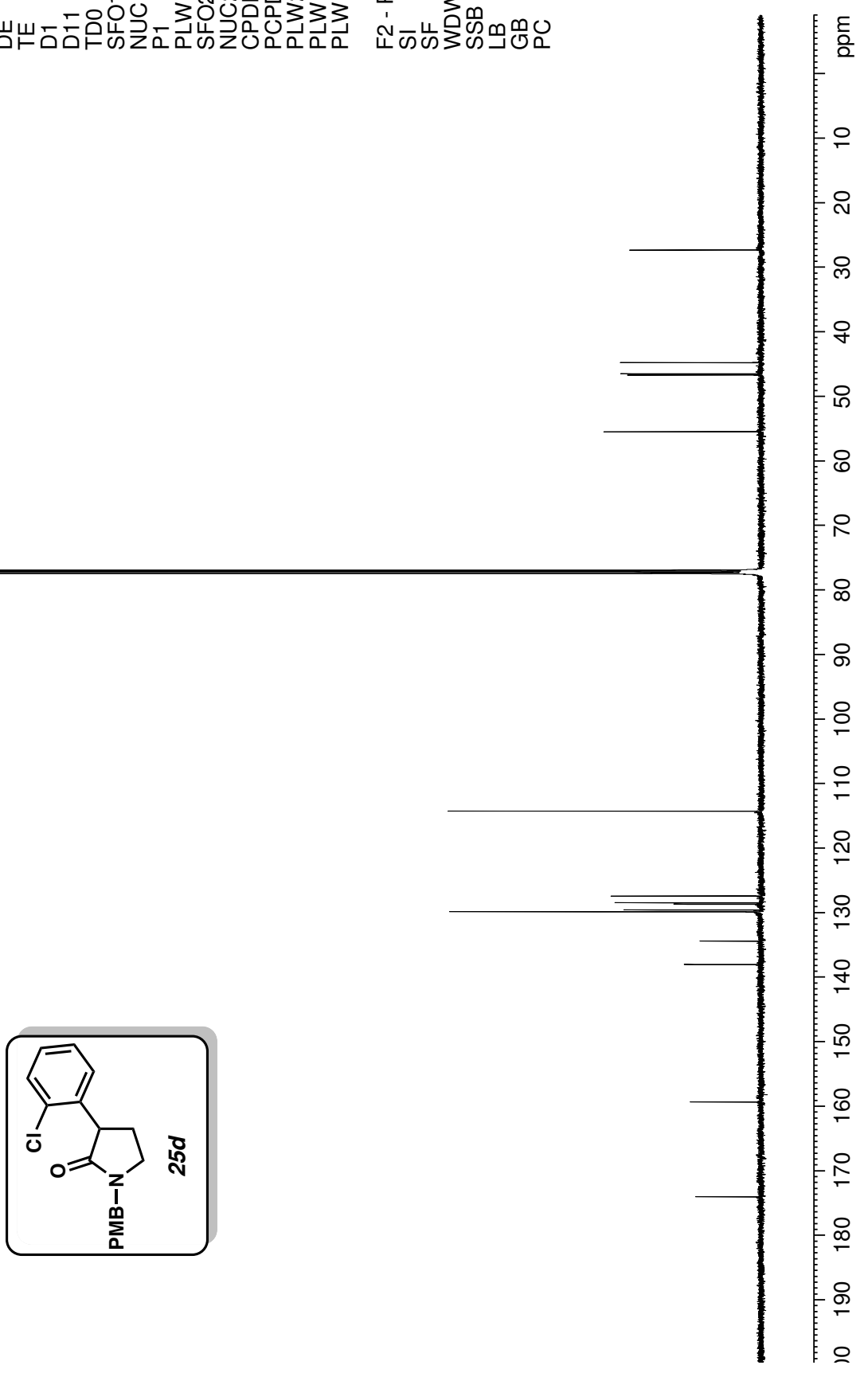


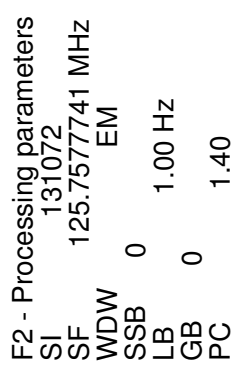

$69 \cdot 0 \varepsilon-$

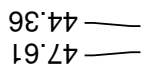

$0 t s 9$

$\varepsilon 8 \cdot 69-$

Sドトトー $\varepsilon<\cdot 9 z+L_{1}$ टZ.8Z1 $80.6 \mathrm{~L}$

26.621

$\angle 9^{\circ} 0 \varepsilon+$

ट6.เEเ

$20^{\circ}+\varepsilon 1$

$\rightarrow 0<\varepsilon$ L

เ2'69 -

てドレレー
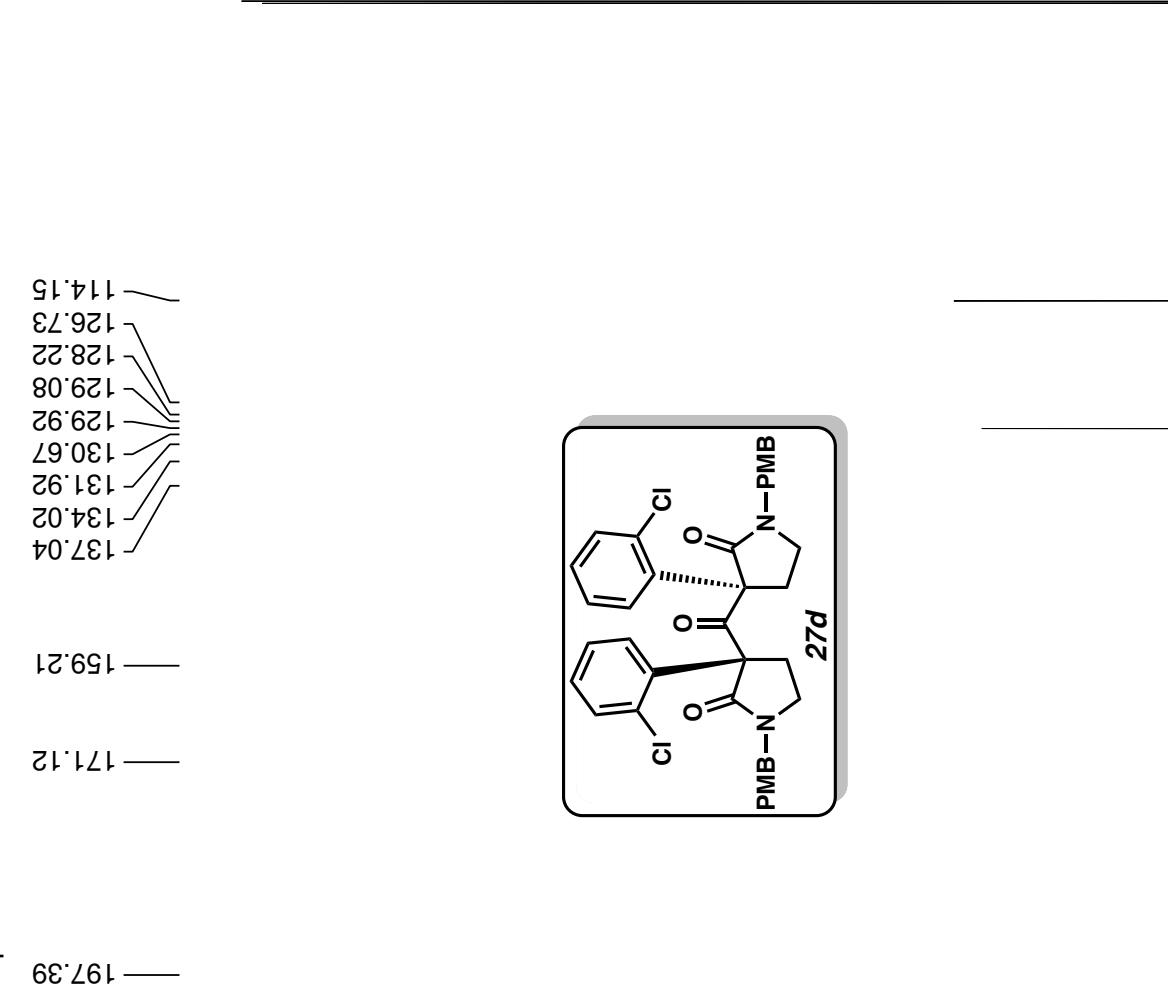

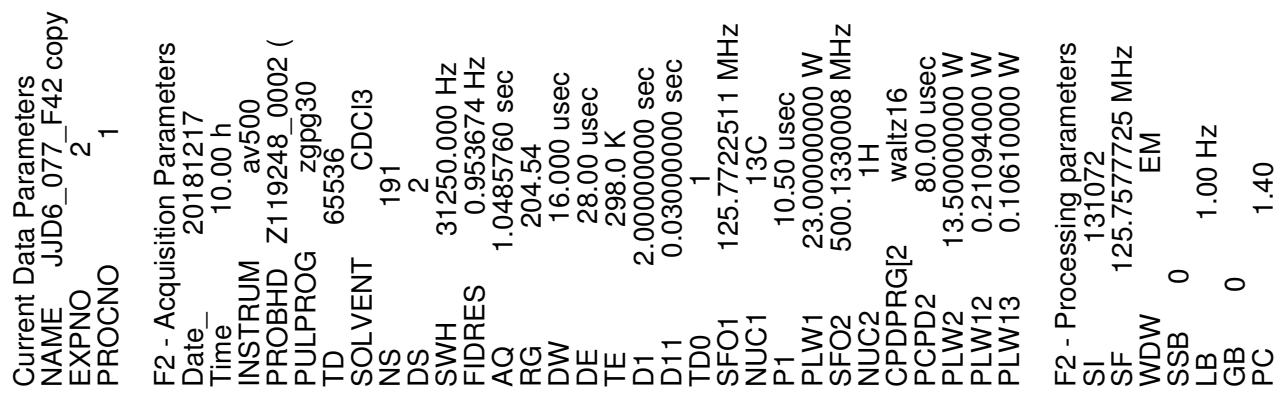

$00^{\circ} 0 \varepsilon$

$62 \cdot 95$

ટ† ९৭

Lレ

งย์ยเト ट0.9己।

$1 Z \cdot \angle Z+$

$\angle 8^{\circ} 6$ CL

$\nabla \nabla^{\circ} 0 \varepsilon+$

$\varepsilon 6 \cdot เ \varepsilon+T$

$8 \varepsilon \cdot \tau \varepsilon+$

เ8. $\varepsilon \varepsilon \vdash$

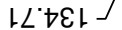
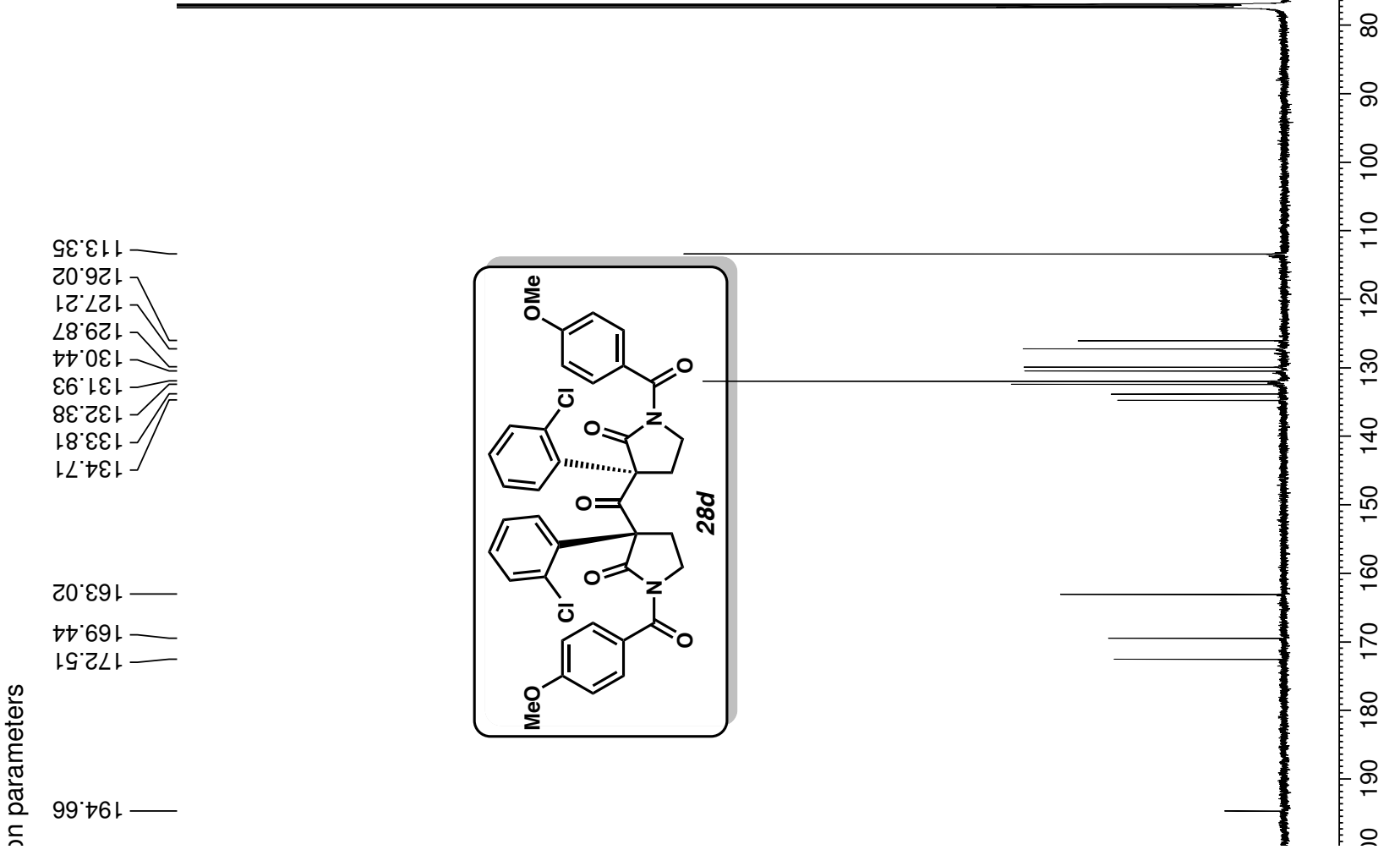


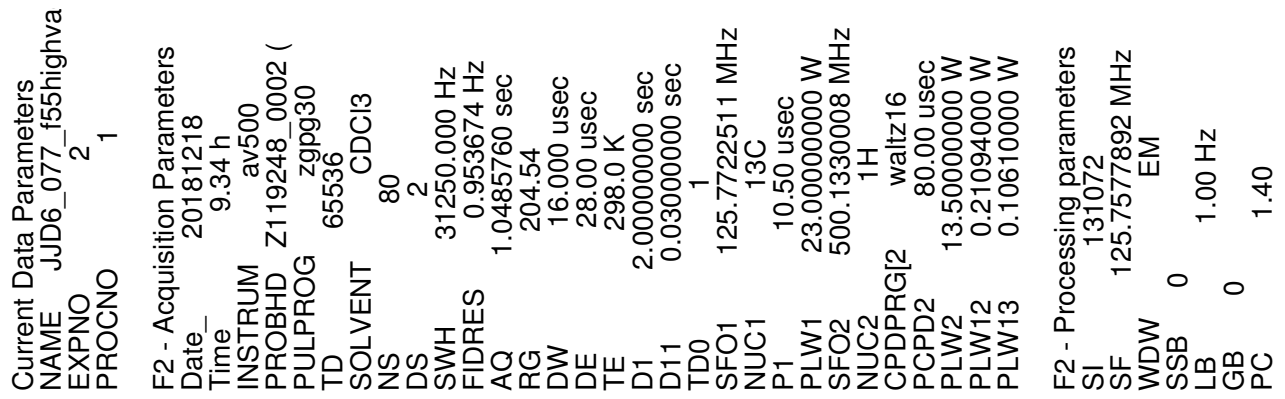

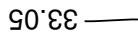

$6 \nabla^{\circ} 6 \varepsilon$

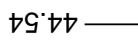

$6 \varepsilon \cdot 99-$

$98 \cdot \angle 9$

†

$00^{\circ} \varepsilon เ$

ᄂ $\angle$ 9टL

86.92 ]

ट† 6己ᄂ

St'6己L

$69^{\circ} 0 \varepsilon$ เ

५8. เEเ

$เ 6^{\circ} เ \varepsilon\llcorner$

เレ'टहเ

$\llcorner\varepsilon \cdot \varepsilon \varepsilon+$

$0{ }^{\circ} \triangleright \varepsilon+$

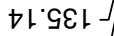

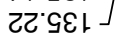

$69 \cdot 291-$

$1869 \mathrm{l}$

$\angle 6 \cdot L 1=$
$\angle \forall+\square L t$
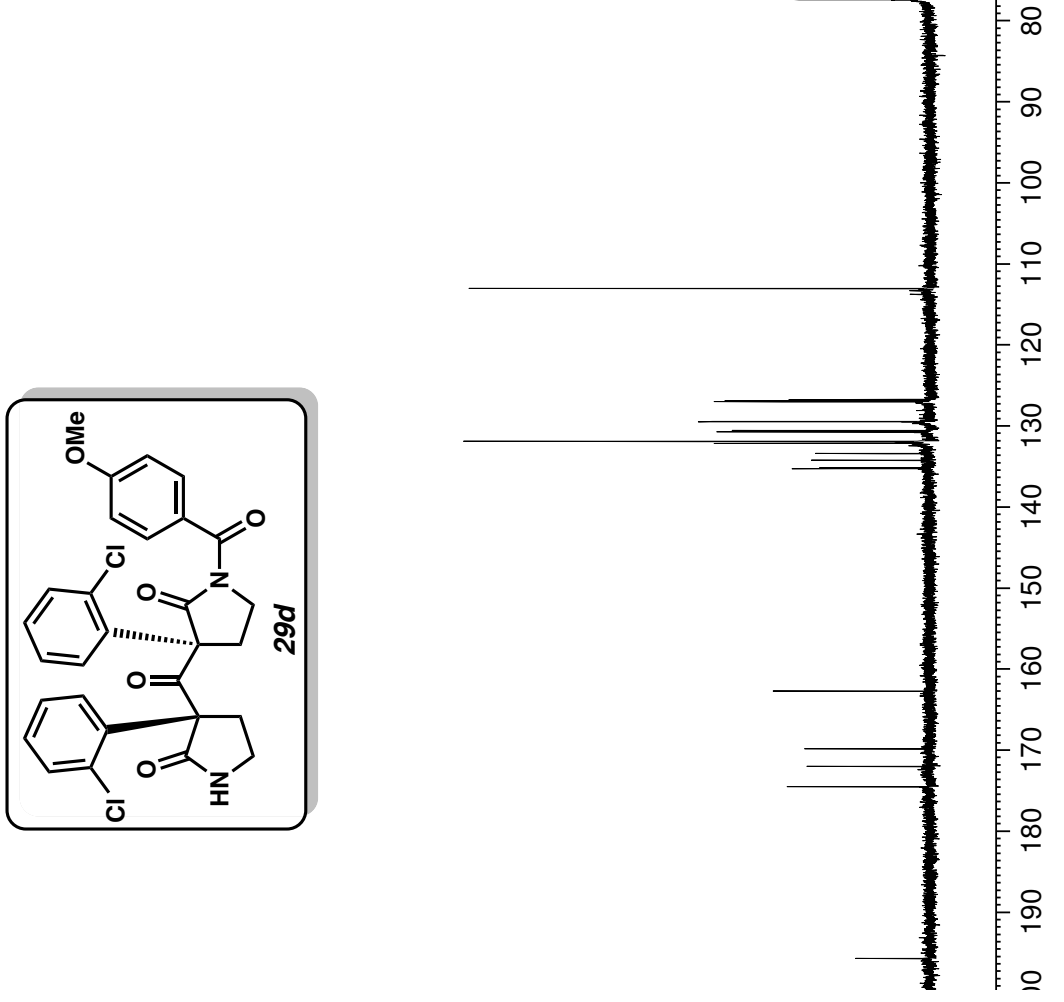

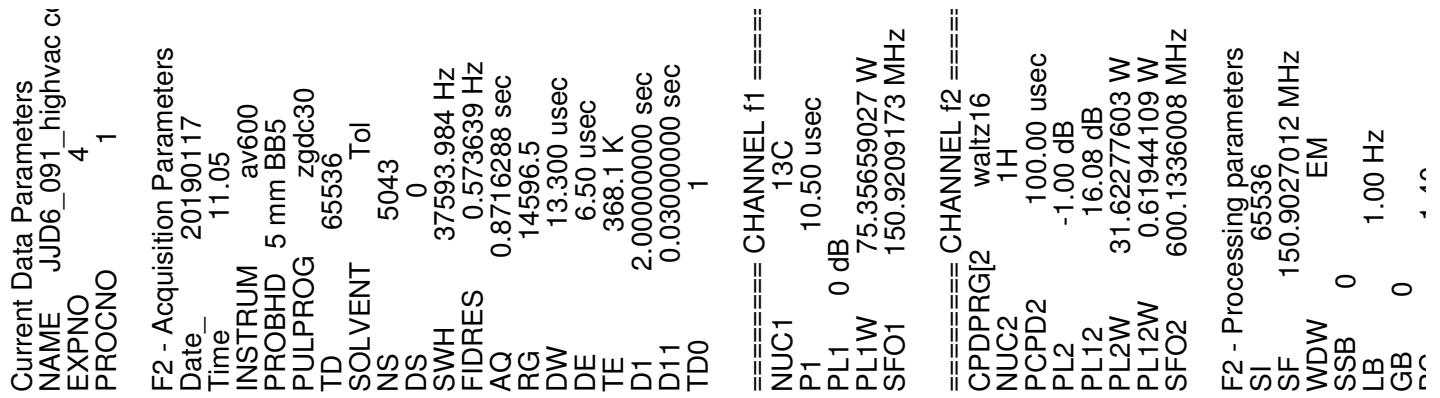

$688^{\circ} 8$

$\varepsilon て ゙ ฑ t$

60 '99 -

†0'29

0น'ยเ —

$10.92 t$

$\varepsilon \nabla^{\circ} 8$ Сน

Gเ'Zعเ

$\angle \nabla \cdot Z \varepsilon+$

$0 \varepsilon^{\cdot} \varepsilon \varepsilon\llcorner$

$8 \varepsilon \cdot \nabla \varepsilon+$

ट9. $9 \varepsilon 1-$

¿५' 891

$\angle L ' 69 \mathrm{l}$

$00^{\circ} S \angle L$

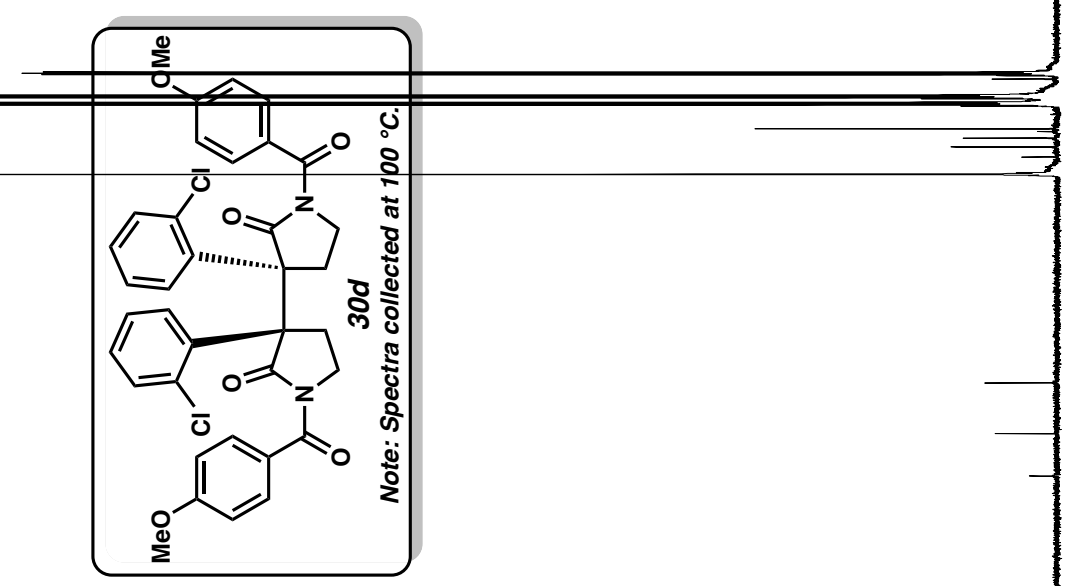



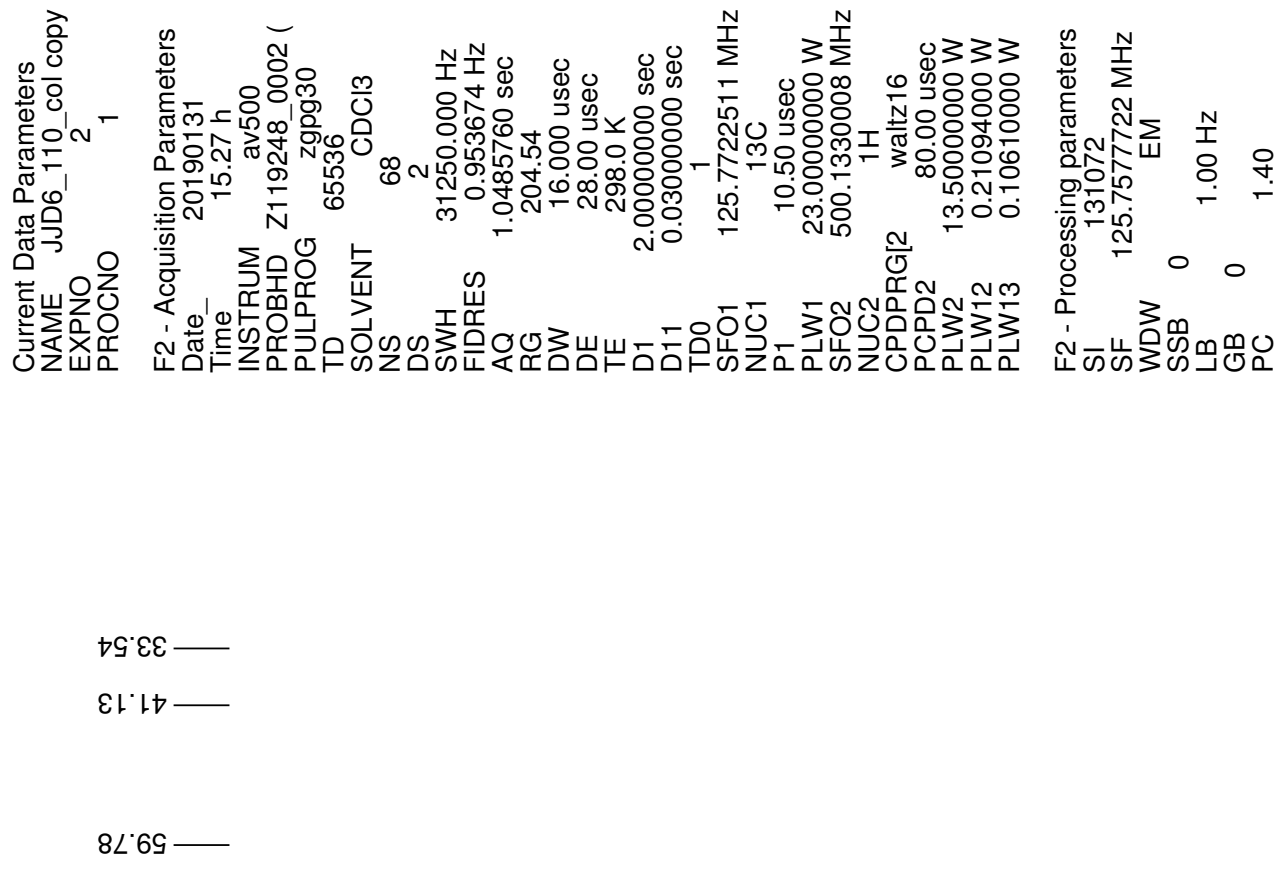

เ๋ $8<+$

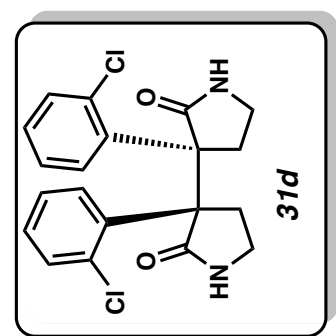




\section{References}

${ }^{1}$ Dotson, J. J.; Bachman, J. L.; Garcia-Garibay, M. A.; Garg, N. K. Discovery and Total Synthesis of a Bis(cyclotryptamine) Alkaloid Bearing the Elusive Piperidinoindoline Scaffold J. Am. Chem. Soc. 2020, 142, 11685-11690.

${ }^{2}$ Resendiz, Ml J. E.; Natarajan, A.; Garcia-Garibay, M. A. Diastereoselective Synthesis and Spin-Dependent Photodecarbonylation of Di(3-phenyl-2-pyrrolidinon-3-yl)ketones: Synthesis of Nonadjacent and Adjacent Stereogenic Quaternary Centers Chem. Commun. 2008, 193195.

${ }^{3}$ Frisch, M. J.; Trucks, G. W.; Schlegel, H. B.; Scuseria, G. E.; Robb, M. A.; Cheeseman, J. R.; Scalmani, G.; Barone, V.; Mennucci, B.; Petersson, G. A.; Nakatsuji, H.; Caricato, M.; Li, X.; Hratchian, H. P.; Izmaylov, A. F.; Bloino, J.; Zheng, G.; Sonnenberg, J. L.; Hada, M.; Ehara, M.; Toyota, K.; Fukuda, R.; Hasegawa, J.; Ishida, M.; Nakajima, T.; Honda, Y.; Kitao, O.; Nakai, H.; Vreven, T.; Montgomery, J. A.; Peralta, J. E.; Ogliaro, F.; Bearpark, M.; Heyd, J. J.; Brothers, E.; Kudin, K. N.; Staroverov, V. N.; Kobayashi, R.; Normand, J.; Raghavachari, K.; Rendell, A.; Burant, J. C.; Iyengar, S. S.; Tomasi, J.; Cossi, M.; Rega, N.; Millam, J. M.; Klene, M.; Knox, J. E.; Cross, J. B.; Bakken, V.; Adamo, C.; Jaramillo, J.; Gomperts, R.; Stratmann, R. E.; Yazyev, O.; Austin, A. J.; Cammi, R.; Pomelli, C.; Ochterski, J. W.; Martin, R. L.; Morokuma, K.; Zakrzewski, V. G.; Voth, G. A.; Salvador, P.; Dannenberg, J. J.; Dapprich, S.; Daniels, A. D.; Farkas; Foresman, J. B.; Ortiz, J. V.; Cioslowski, J.; Fox, D. J. Gaussian 09; Gaussian Inc.: Wallingford, CT, 2009.

${ }^{4}$ Dapprich, S.; Komáromi, I.; Byun, K. S.; Morokuma, K.; Frisch, M. J. A New ONIOM Implementation in Gaussian98. Part I. The Calculation of Energies, Gradients, Vibrational Frequencies and Electric Field Derivatives. J. Mol. Struct. 1999, 461, 1-21. 
${ }^{5}$ Vreven, T.; Byun, K. S.; Komáromi, I.; Dapprich, S.; Montgomery, J. A.; Morokuma, K.; Frisch, M. J. Combining Quantum Mechanics Methods with Molecular Mechanics Methods in ONIOM. J. Chem. Theory Comput. 2006, 2, 815-826.

${ }^{6}$ This type of QM/MM strategy to model a reaction in the crystalline solid state was reported in the following reference: Keating, A. E.; Shin, S. H.; Houk, K. N.; Garcia-Garibay, M. A. Combining Quantum Mechanical Reaction Pathways with Force Field Lattice Interactions To Model a Solid-State Phototransformation. J. Am. Chem. Soc. 1997, 119, 1474-1475.

${ }^{7}$ Mayer, M. M. Understanding Hydrogen Atom Transfer: From Bond Strengths to Marcus Theory. Acc. Chem. Res. 2011, 44, 36-46.

${ }^{8}$ Neumann, M.; Johnson, M.; von Laue, L.; Trommsdorff, H. P. Proton Tunneling in Molecular Solids. J. Lumin. 1996, 66, 146-151.

${ }^{9}$ Castro, C.; Karney, W. L. Heavy-Atom Tunneling in Organic Reactions. Angew. Chem., Int. Ed. 2020, 59, 8355-8366.

${ }^{10}$ Reynhardt, E. C.; Latanowicz, L. ${ }^{1} \mathrm{H}$ and ${ }^{2} \mathrm{H}$ NMR Relaxation in Hydrogen-Bonded Solids Due to a Complex Motion: Classical Jumps Over a Barrier and Incoherent Tunneling. J. Magn. Reson. 1998, 130, 195-208.

${ }^{11}$ Klein, O.; Aguilar-Parilla, F.; Lopez, J. M.; Jagerovic, N.; Elguero, J.; Limbach, H. H. Dynamic NMR Study of the Mechanisms of Double, Triple, and Quadruple Proton and Deuteron Transfer in Cyclic Hydrogen Bonded Solids of Pyrazole Derivatives. J. Am. Chem. Soc. 2004, 126, 11718-11732.

${ }^{12}$ Braun, J.; Schwesinger, R.; Williams, P. G.; Morimoto, H.; Wemmer, D. E.; Limbach, H. H. Kinetic H/D/T Isotope and Solid-State Effects on the Tautomerism of the Conjugate Porphyrin Monoanion. J. Am. Chem. Soc. 1996, 118, 11101-11110. 
${ }^{13}$ Williams, F.; Sprague, E. D. Novel Radical Anions and Hydrogen Atom Tunneling in the Solid State. Acc. Chem. Res. 1982, 15, 408-415.

${ }^{14}$ Garcia-Garibay, M. A.; Gamarnik, A.; Bise, R.; Pang, L.; Jenks, W. S. Primary Isotope Effects on Excited State Hydrogen Atom Transfer Reactions. Activated and Tunneling Mechanisms in an ortho-Methylanthrone. J. Am. Chem. Soc. 1995, 117, 10264-10275.

${ }^{15}$ Campos, L. M.; Warrier, M. V.; Peterfy, K.; Houk, K. N.; Garcia-Garibay, M. A. Secondary Alpha Isotope Effects on Deuterium Tunneling in Triplet $o$-Methylanthrones: Extraordinary Sensitivity to Barrier Width. J. Am. Chem. Soc. 2005, 127, 10178-10179.

${ }^{16}$ Rodriguez, J. A.; Eisenberg, D. S.; Gonen, T. Taking the Measure of MicroED. Curr. Opin. Struct. Biol. 2017, 46, 79-86.

${ }^{17}$ Jones, C. G.; Martynowycz, M. W.; Hattne, J.; Fulton, T. J.; Stoltz, B. M.; Rodriguez, J. A.; Nelson, H. M.; Gonen, T. The CryoEM Method MicroED as a Powerful Tool for Small Molecule Structure Determination. ACS Cent. Sci. 2018, 4, 1587-1592. 